\title{
RECOVERY OF WATER FROM BOILER FLUE GAS USING CONDENSING HEAT EXCHANGERS
}

\author{
FINAL TECHNICAL REPORT
}

October 1, 2008 to March 31, 2011

\author{
by \\ Edward Levy, Harun Bilirgen and John DuPont
}

Report Issued June 2011

DOE Award Number DE-NT0005648

\author{
Energy Research Center \\ Lehigh University \\ 117 ATLSS Drive \\ Bethlehem, PA 18015
}




\section{DISCLAIMER}

"This report was prepared as an account of work sponsored by an agency of the United States Government. Neither the United States Government nor any agency thereof, nor any of their employees, makes any warranty, express or implied, or assumes any legal liability or responsibility for the accuracy, completeness, or usefulness of any information, apparatus, product, or process disclosed, or represents that its use would not infringe privately owned rights. Reference herein to any specific commercial product, process, or service by trade name, trademark, manufacturer, or otherwise does not necessarily constitute or imply its endorsement, recommendation, or favoring by the United States Government or any agency thereof. The views and opinions of authors expressed herein do not necessarily state or reflect those of the United States Government or any agency thereof." 


\section{ACKNOWLEDGEMENTS}

In addition to the U.S. Department of Energy, the authors of this report are extremely grateful to Southern Company and Lehigh University for supporting this project.

The authors are also grateful to the other members of the Lehigh project team, which included Dr. Hugo Caram and Messrs. Michael Kessen, Daniel Hazell, Jason Thompson, Gordon Jonas, Nipun Goel, and Zheng Yao. 


\begin{abstract}
Most of the water used in a thermoelectric power plant is used for cooling, and DOE has been focusing on possible techniques to reduce the amount of fresh water needed for cooling. DOE has also been placing emphasis on recovery of usable water from sources not generally considered, such as mine water, water produced from oil and gas extraction, and water contained in boiler flue gas. This report deals with development of condensing heat exchanger technology for recovering moisture from flue gas from coal-fired power plants. The report describes:

- An expanded data base on water and acid condensation characteristics of condensing heat exchangers in coal-fired units. This data base was generated by performing slip stream tests at a power plant with high sulfur bituminous coal and a wet FGD scrubber and at a power plant firing highmoisture, low rank coals.
\end{abstract}

- Data on typical concentrations of $\mathrm{HCl}, \mathrm{HNO}_{3}$ and $\mathrm{H}_{2} \mathrm{SO}_{4}$ in low temperature condensed flue gas moisture, and mercury capture efficiencies as functions of process conditions in power plant field tests.

- Theoretical predictions for sulfuric acid concentrations on tube surfaces at temperatures above the water vapor dewpoint temperature and below the sulfuric acid dew point temperature.

- Data on corrosion rates of candidate heat exchanger tube materials for the different regions of the heat exchanger system as functions of acid concentration and temperature.

- Data on effectiveness of acid traps in reducing sulfuric acid concentrations in a heat exchanger tube bundle.

- Condensed flue gas water treatment needs and costs.

- Condensing heat exchanger designs and installed capital costs for full-scale applications, both for installation immediately downstream of an ESP or baghouse and for installation downstream of a wet $\mathrm{SO}_{2}$ scrubber.

- Results of cost-benefit studies of condensing heat exchangers. 
Page

$\begin{array}{ll}\text { CHAPTER } 1 & 1-1\end{array}$

INTRODUCTION

Background $1-1$

Project Description $\quad 1-4$

References $1-5$

$\begin{array}{lr}\text { CHAPTER } 2 & \text { 2-1 }\end{array}$

POWER PLANT SLIP STREAM TESTS OF HEAT EXCHANGERS $2-1$

Introduction 2-1

Flue Gas and Cooling Water Conditions $2-1$

Experimental Apparatus and Variables Tested 2-2

Results $\quad 2-5$

Heat Exchanger Performance $2-5$

Capture of Acids and Mercury $2-10$

Summary and Conclusions $\quad 2-14$

References $\quad 2-16$

$\begin{array}{lr}\text { CHAPTER } 3 & 3-1\end{array}$

CONCENTRATIONS OF DEPOSITS OF SULFURIC ACID AND WATER ON 3-1 HEAT EXCHANGER TUBES

Introduction 3-1

Concentrations of Sulfuric Acid-Water Mixtures at Temperatures above $\quad 3-2$ the Water Vapor Due Point Temperature Acid Concentrations at Temperatures Below the Water Vapor Due Point $\quad 3-5$ Temperature

References $\quad 3-6$

CHAPTER $4 \quad 4-1$

LABORATORY CORROSION TESTS OF CANDIDATE HEAT EXCHANGER 4-1 TUBE MATERIALS

Introduction $\quad 4-1$

Experimental Procedure $\quad 4-2$

Results and Discussion $\quad 4-5$

Conclusions $\quad 4-31$

References $\quad 4-32$ 
Page

CHAPTER 5

REDUCING SULFURIC ACID DEPOSITION ON HEAT EXCHANGER

TUBES: MEASUREMENT OF ACID TRAP EFFECTIVENESS

Introduction

Results of Slip Stream Tests

$5-1$

Flue Gas from Gas-Fired Boiler

$5-1$

Flue Gas from Unit B

5-5

Flue Gas from Unit C

5-8

Gypsum Deposition

$5-13$

Conclusions

5-14

Tests at Gas-Fired Boiler

5-14

Tests at Unit B

5-14

Tests at Unit C

5-15

Final Comments

CHAPTER 6

CONDENSING HEAT EXCHANGER DESIGN ANALYSES

Introduction

6-1

Heat Exchanger Simulation Method

$6-3$

Design of Full-Scale Heat Exchangers

6-5

Heat Exchanger Dimensions and Process Parameters

6-5

Choice of Tube Material

6-6

Heat Exchangers for $300^{\circ} \mathrm{F}$ and $135^{\circ} \mathrm{F}$ Inlet Gas Temperatures

$6-10$

Summary

6-17

Reference

TREATMENT OF CONDENSED WATER FOR USE AS COOLING TOWER MAKEUP WATER

Introduction

Cooling Tower Makeup Water

Water Analyses: Condensed (Capture) Water and Typical Makeup Water Condensed Water Treatment 
Page

$\begin{array}{lr}\text { CHAPTER } 8 & \text { 8-1 }\end{array}$

COST-BENEFIT ANALYSIS

Introduction 8-1

Analysis of Costs and Benefits

Conclusions $\quad 8-7$

$\begin{array}{lr}\text { CHAPTER } 9 & 9-1\end{array}$

$\begin{array}{lr}\text { SUMMARY } & 9-1\end{array}$

Power Plant Slip Stream Tests $\quad 9-1$

Laboratory Corrosion Tests $\quad 9-2$

Effectiveness of Acid Traps $\quad 9-3$

Design of Full-Scale Heat Exchangers $\quad 9-4$

Treatment of Condensed Water $\quad 9-5$

Cost-Benefit Analyses $\quad 9-6$

APPENDIX A A-1

ALLOY PROPERTIES AND CORROSION TEST DATA A-1 


\section{LIST OF TABLES}

$\underline{\text { Table }}$

$\underline{\text { Page }}$

1-1 Estimated Fractions of Cooling Tower Makeup Water Provided

by Condensing Heat Exchangers, Assuming 100 Percent Water Vapor Capture

2-1 Acid Concentrations (mg/L)

3-1 Coefficients for Abel's Equation for the Vapor Pressure of Sulfuric Acid as a Function of Mass Fraction of $\mathrm{H}_{2} \mathrm{SO}_{4}$ in Liquid Phase $(\pi)$ and Acid Dew Point Temperature

3-2 Acid Concentrations (mg/L)

4-1 Summary of Condensate Compositions and Temperatures.

4-2 Summary of Alloys Tested Under Various Conditions.

4-4

4-3 Summary of Corrosion Rates Measured Under Condition 1. All 4-6 Values in $\mathrm{mm} /$ year.

4-4 Summary of Corrosion Rates Measured Under High Acid 4-6 Condensate Solutions. All Values in $\mathrm{mm} / \mathrm{year}$.

4-5 Summary of Corrosion Rates Measured Under Low Acid Condensate Conditions. All Values in mm/year.

4-6 Summary of In (A), B, and $\mathrm{R}^{2}$ Values From Arrhenius Plots

Provided in Figures 4-18 through 4-21.

5-1 Surface Areas of Heat Exchangers and Acid Trap

5-2 Process Conditions for Acid Deposition Tests 5-3

5-3 $\mathrm{SO}_{3}$ Capture Tests at Gas Fired Boiler with $\mathrm{SO}_{3}$ Injection 5-5

5-4 Measured $\mathrm{SO}_{3}$ Concentration and Flue Gas Temperature, Both With 5-8 and Without $\mathrm{SO}_{3}$ Injection.

5-5 Measured $\mathrm{SO}_{3}$ Concentration at Inlet and Exit of Acid Trap: Tests with $\mathrm{SO}_{3}$ Injection

5-6 Measurements of Sulfate Concentration, Total Liquid Deposition and Sulfate Deposition Rates 


\section{LIST OF TABLES (continued)}

$\underline{\text { Table }}$

Page

6-1 Tube Material Properties and Costs 6-6

6-2 Predicted Heat Exchanger Costs and Condensation and Heat

Transfer Rates vs. Heat Exchanger Length for $300^{\circ} \mathrm{F}$ and $135^{\circ} \mathrm{F}$ Inlet Flue Gas Temperatures and $90^{\circ} \mathrm{F}$ Inlet Cooling Water Temperature.

7-1 Ranges of Impurity Concentrations in Condensed Water

7-2 Ranges of Heavy Metal Concentrations in Condensed Water 7-3

7-3 Projected Ranges of Concentrations of Impurities in Condensed 7-4 Water for a 500 MW Coal-Fired Power Plant

7-4 Typical Cooling Tower Water, River Water, and Makeup Water Analyses (Performed on Three Different Days)

7-5 Comparisons of Water Compositions on Average Basis - Typical Cooling Tower Water, Cooling Tower Makeup Water and Condensed Water

7-6 Approximate Costs of Ion Exchange and Adsorption [2].

7-7 Approximate Costs of an lon Exchange Water Treatment System for Treating Condensed Water from a 500 MW Power Plant

7-8 Unit Cost of Makeup Water from Ion Exchange Treatment System

8-1 Heat Exchanger Process Conditions, Heat and Mass Transfer Rates, 8-5 Costs and Unit Performance Impacts

8-2 Cost-Benefit Summary: Case $1 \quad 8-6$

8-3 Cost-Benefit Summary: Case $2 \quad 8-6$

8-4 Cost-Benefit Summary: Case $3 \quad 8-7$

9-1 Measured Acid Concentration (mg/L) in Condensate which Formed 9-2 at Temperatures Below the Water Vapor Dew Point Temperature

9-2 Cost-Benefit Analysis for Heat Exchanger Located Downstream $\quad 9-7$ of Wet FGD 


\section{LIST OF TABLES (continued)}

$\underline{\text { Table }}$

Page

9-3 Cost-Benefit Analysis of Heat Exchanger in Unit Without Wet FGD 9-8 and with $210^{\circ} \mathrm{F}$ Cooling Water Exit Temperature

9-4 Cost-Benefit Analysis of Heat Exchanger in Unit Without Wet FGD 9-8 and with $146^{\circ} \mathrm{F}$ Cooling Water Exit Temperature 


\section{LIST OF FIGURES}

Figure

Page

1-1 Sulfuric Acid Dew Point Temperature vs. Acid Concentration (Refs. 1 to 4)

1-2 Water Vapor Dew Point vs. Volumetric Concentration (Ref 5)

1-3 Dew Point Temperatures of Hydrochloric and Nitric Acids $1-4$ (Ref. 6 and 7)

2-1 Water Vapor Dewpoint Temperature vs. Volumetric Concentration

2-2 Sulfuric Acid Dew Point Temperature vs. Acid Concentration 2-3

2-3 Dew Point Temperatures of Hydrochloric and Nitric Acids 2-3

2-4 Elevation View of Test Apparatus $\quad 2-4$

2-5 Axial Variations of Flue Gas, Water Vapor Dew Point, and Tube Wall 2-6 Temperatures: Unit B

2-6 Water Vapor Condensation Rates on the Five Heat Exchangers: Unit B 2-6

2-7 Variation of Rate of Total Heat Transfer with Cooling Water to Flue 2-7 Gas Mass Flow Rate Ratio: Unit B

2-8 Variation of Water Vapor Capture Efficiency with Cooling Water to $\quad$ 2-7 Flue Gas Mass Flow Rate Ratio: Unit B

2-9 Flue Gas and Cooling Water Temperature Profiles: Unit C 2-8

2-10 Rate of Total Heat Transfer vs. Ratio of Mass Flow Rate of Cooling 2-9 Water to Flue Gas: Unit C

2-11 Water Vapor Capture Efficiency vs. Ratio of Mass Flow Rate of 2-9 Cooling Water to Flue Gas: Unit C

2-12 Water Vapor Capture Efficiency vs. Inlet Cooling Water Temperature: 2-10 Unit A

2-13 Condensate Sulfate Concentration from the Four Heat Exchangers. 2-11 Flue Gas Entered at HX1 and Exited at HX4: Boiler C. 


\section{LIST OF FIGURES (continued)}

Figure

Page

2-14 Chloride Flow Rates from Heat Exchangers HX3 to HX6 versus Tube Wall Temperature. Coal Test Data from Three Tests with $77^{\circ} \mathrm{F}$ Inlet Cooling Water Temperature. Boiler A.

2-15 Nitrate Flow Rates from Heat Exchangers HX3 to HX6 versus Tube Wall Temperature. Coal Test Data from Four Tests with $77^{\circ} \mathrm{F}$ Inlet Cooling Water Temperature. Boiler A.

2-16 Inlet and Exit Values of Flue Gas Mercury at Unit A. Data Plotted in the Order in which the Tests Were Carried Out and the Measurements Made.

2-17 Percentage Reduction in Mercury Concentration as a Function of Flue Gas Exit Temperature: Unit B.

3-1 This graph can be used to determine the acid weight percent in the liquid phase as a function of flue gas water vapor volume concentration and acid dew point temperature, or equivalently, the tube wall temperature.

4-1 Setup of the Long-Term Corrosion Testing. A) Side View of the Bath B) Overhead View of the Bath C) Side View of the Test Tube Showing the Individual Components of the Test Tube Setup.

4-2 Corrosion Rate of Nickel Alloys as a Function of Temperature.

Results Shown are for the High Acid Test Conditions.

4-3 Corrosion Rate of Steels as a Function of Temperature. Results Shown are for the High Acid Test Conditions.

4-4 Corrosion Rate of Aluminum Bronze Alloy as a Function of

Temperature. Results Shown are for the High Acid Test Conditions.

4-5 Corrosion Rates of Steels, Aluminum Alloys, and Aluminum Bronze

Alloy as a Function of Temperature. Results Shown are for the Low Acid Test Conditions.

4-6 Photographs of Various Materials from the Low Acid Test Condition.

4-7 Photographs of Samples of Alloy 690 from the High Acid Test Conditions. 


\section{LIST OF FIGURES (continued)}

Figure $\quad \underline{\text { Page }}$

4-8 Photographs of Samples of Alloy 22 from the High Acid Test 4-14 Conditions.

4-9 Photographs of Samples of Alloy 59 from the High Acid Test Conditions.

4-10 Photographs of Samples of Alloy 625 from the High Acid Test Conditions.

4-11 Photomicrographs of 690 Following Corrosion Testing at $115^{\circ} \mathrm{C}$ in 74 percent $\mathrm{H}_{2} \mathrm{SO}_{4}$. a) Image Showing Mounted Cross-Section, b) $5 x$ Objective, c) 20x Objective, and d) 50x Objective.

4-12 Photomicrographs of Alloy 22 Following Corrosion Testing at $115^{\circ} \mathrm{C}$ in 74 Percent $\mathrm{H}_{2} \mathrm{SO}_{4}$. a) Image Showing Mounted Cross-Section, b) $5 x$ Objective, c) 20x Objective, and d) 50x Objective.

4-13 Photomicrographs of Alloy 59 Following Corrosion Testing at $115^{\circ} \mathrm{C}$ in 74 Percent $\mathrm{H}_{2} \mathrm{SO}_{4}$. a) Macro-Image Showing Mounted CrossSection, b) Higher Magnification of Mounted Cross-Section Showing Large Areas of Corroded Material.

4-14 Photographs of FEP from the High Acid Test Conditions.

4-15 Photographs of PTFE From the High Acid Test Conditions. 4-20

4-16 Photographs of PEEK From the High Acid Test Conditions. 4-21

4-17 Photographs of Graphite From the High Acid Test Conditions. 4-22

4-18 Photographs of Teflon Coated Samples From the Low Acid 4-23 Concentration Test Conditions.

4-19 Photographs of Teflon Coated Samples From the High Acid 4-24 Concentration Test Conditions.

4-20 Arrhenius Plot of In(Corrosion Rate) as a Function of $1 / T$ for the 4-26 Nickel Alloys in the High Acid Concentration Tests.

4-21 Arrhenius Plot of $\ln$ (Corrosion Rate) as a Function of $1 / T$ for the Steels in the High Acid Concentration Tests. 


\section{LIST OF FIGURES (continued)}

Figure

Page

4-22 Arrhenius Plot of $\ln$ (Corrosion Rate) as a Function of $1 / T$ for the Aluminum Bronze Alloy in the High Acid Concentration Tests.

4-23 Arrhenius Plot of In(Corrosion Rate) as a Function of $1 / T$ for the Steels, Aluminum Alloys, and Aluminum Bronze Alloy in the Low Acid Concentration Tests.

5-1 Diagram of Heat Exchanger Arrangement Used for Tests at Natural Gas-Fired Boiler

5-2 Flue Gas, Cooling Water, and Dew Point Temperature Distributions 5-4 within Heat Exchanger Array

5-3 Measured Water Vapor Condensation Rates on the Five Heat Exchangers During Test 1

5-4 Predicted Flue Gas Water Vapor Mole Fraction Distribution within Heat Exchanger Array

5-5 Arrangement of Heat Exchangers and Acid Trap

5-6 Flue Gas Temperature and $\mathrm{SO}_{3}$ Concentration at Heat Exchanger Inlet. Comparison to Acid Dew Point Temperatures.

5-7 Acid Dew Point Temperature as a Function of Vapor Phase Concentration of $\mathrm{SO}_{3}$.

5-8 Heat Exchanger Configurations Tested at Plant Yates

5-9 Condensate Sulfate Concentration from the Four Heat Exchangers: $\quad$ 5-11 Without Acid Traps

5-10 Sulfate Flux on the Four Heat Exchangers: Without Acid Traps

5-11 Sulfate Flux on HX1: Comparison of No Traps to Trap 1

5-12 Sulfate Flux on HX2: Comparison of the Four HX Configurations

5-13 Sulfate Deposition Rate on All Four Heat Exchangers and the Acid Traps: First Two Hour Test Period

5-14 Sulfate Deposition Rate on All Four Heat Exchangers and the Acid Traps: Second Two Hour Test Period 


\section{LIST OF FIGURES (continued)}

Figure

Page

5-15 Calcium Concentration in Condensate on Four Heat Exchangers: $\quad$ 5-14 Comparison of No Trap with Trap 1

6-1 Variation of Flue Gas Moisture Fraction with Distance through the Heat Exchanger: Comparison of Predicted and Measured Values

6-2 Variations of Flue Gas and Cooling Water Temperatures with Distance through the Heat Exchanger: Comparison of Predicted and Measured Values

6-3 Comparison of Predicted and Measured Values of Condensation Efficiency vs. Cooling Water Temperature

6-4 Comparison of Predicted and Measured Values of Condensation Efficiency

6-5 Two Dimensional Diagram of Heat Exchanger: Side View. 6-5

6-6 Temperature Profiles Through an Alloy 22 Heat Exchanger 6-7

6-7 Temperature Profiles Through a Teflon Heat Exchanger 6-8

6-8 Total Heat Transfer vs. Surface Area. Comparison of Teflon and 6-9 Alloy 22 Heat Exchangers

6-9 Total Heat Transfer vs. Annual Cost. Comparison of Teflon and 6-10 Alloy 22 Heat Exchangers.

6-10 Condensation Efficiency vs. Heat Exchanger Size for $300^{\circ} \mathrm{F}$ Inlet Flue Gas Temperature. Effect of Inlet Cooling Water Temperature.

6-11 Condensation Rate vs. Heat Exchanger Size for $300^{\circ} \mathrm{F}$ Inlet Flue Gas 6-12 Temperature. Effect of Inlet Cooling Water Temperature.

6-12 Heat Transfer Rate vs. Heat Exchanger Size for $300^{\circ} \mathrm{F}$ Inlet Flue Gas Temperature. Effect of Inlet Cooling Water Temperature.

6-13 Condensation Efficiency vs. Heat Exchanger Size for $300^{\circ} \mathrm{F}$ Inlet Flue Gas Temperature. Effect of Cooling Water to Flue Gas Flow Rate Ratio.

6-14 Condensation Efficiency vs. Heat Exchanger Size for $135^{\circ} \mathrm{F}$ Inlet Flue Gas Temperature. Effect of Inlet Cooling Water Temperature. 


\section{LIST OF FIGURES (continued)}

Figure

Page

6-15 Condensation Rate vs. Heat Exchanger Size for $135^{\circ} \mathrm{F}$ Inlet Flue Gas Temperature. Effect of Inlet Cooling Water Temperature.

6-16 Heat Transfer Rate vs. Heat Exchanger Size for $135^{\circ} \mathrm{F}$ Inlet

Flue Gas Temperature. Effect of Inlet Cooling Water Temperature.

6-17 Condensation Efficiency vs. Heat Exchanger Size for $135^{\circ} \mathrm{F}$ Inlet Flue Gas Temperature. Effect of Cooling Water to Flue Gas Flow Rate Ratio.

6-18 Performance Comparison of $135^{\circ} \mathrm{F}$ and $300^{\circ} \mathrm{F}$ Heat Exchangers.

7-1 Condensing Heat Exchanger Test Apparatus - Water Recovery System (WRS).

7-2 Proposed Water Treatment Process for the Condensate Water

7-3 A Sketch of an Ion Exchange System

7-12

8-1 Turbine Cycle Diagram Showing Flow Rates, Temperatures and Pressures

8-2 Diagram of Preheated Boiler Feedwater Entering Feedwater Heater 3

A1 Plot of Thickness Loss in mm Versus Time in Days for Materials in a 60 Percent $\mathrm{H}_{2} \mathrm{SO}_{4}$ Solution at $121^{\circ} \mathrm{C}$.

A-1

A2a Plot of Thickness Loss in mm Versus Time in Days for Materials in a 65 Percent $\mathrm{H}_{2} \mathrm{SO}_{4}$ Solution at $50^{\circ} \mathrm{C}$.

A2b Plot of Thickness Loss in $\mathrm{mm}$ Versus Time in Days for Materials in a 65 Percent $\mathrm{H}_{2} \mathrm{SO}_{4}$ Solution at $50^{\circ} \mathrm{C}$ that was Retested to Confirm the Trends.

A3a Plot of Thickness Loss in mm Versus Time in Days for Materials in a 67 Percent $\mathrm{H}_{2} \mathrm{SO}_{4}$ Solution at $67.5^{\circ} \mathrm{C}$.

A3b Plot of Thickness Loss in mm Versus Time in Days for Materials in a A-3 67 Percent $\mathrm{H}_{2} \mathrm{SO}_{4}$ Solution at $67.5^{\circ} \mathrm{C}$ Tested a Second Time to Confirm Trends. 


\section{LIST OF FIGURES (continued)}

$\underline{\text { Figure }}$

Page

A4a Plot of Thickness Loss in mm Versus Time in Days for Materials $\quad$ A-4 in a 70 Percent $\mathrm{H}_{2} \mathrm{SO}_{4}$ Solution at $85^{\circ} \mathrm{C}$.

A4b Plot of Thickness Loss in mm Versus Time in Days for Materials A-4 in a 70 Percent $\mathrm{H}_{2} \mathrm{SO}_{4}$ Solution at $85^{\circ} \mathrm{C}$ Tested for a Second Time to Confirm Trends.

A5a Plot of Thickness Loss in mm Versus Time in Days for Materials in a 74 Percent $\mathrm{H}_{2} \mathrm{SO}_{4}$ Solution at $115^{\circ} \mathrm{C}$.

A-5

A-5

A5b Plot of Thickness Loss in mm Versus Time in Days for Materials in a 74 Percent $\mathrm{H}_{2} \mathrm{SO}_{4}$ Solution at $115^{\circ} \mathrm{C}$ Tested a Second Time to Confirm Trends.

A6 Plot of Thickness Loss in $\mathrm{mm}$ Versus Time in Days for Materials in a 80 Percent $\mathrm{H}_{2} \mathrm{SO}_{4}$ Solution at $150^{\circ} \mathrm{C}$.

A7 Plot of Thickness Loss in mm Versus Time in Days for Materials in a $50 \mathrm{mg} / \mathrm{L} \mathrm{H}_{2} \mathrm{SO}_{4} 10 \mathrm{mg} / \mathrm{L} \mathrm{HCl} 0.5 \mathrm{mg} / \mathrm{L} \mathrm{HNO}_{3}$ solution at $21^{\circ} \mathrm{C}$.

A8a Plot of Thickness Loss in mm Versus Time in Days for Materials in a $375 \mathrm{mg} / \mathrm{L} \mathrm{H}_{2} \mathrm{SO}_{4} 110 \mathrm{mg} / \mathrm{L} \mathrm{HCl} 2.3 \mathrm{mg} / \mathrm{L} \mathrm{HNO}_{3}$ Solution at $54^{\circ} \mathrm{C}$.

A8b Plot of Thickness Loss in mm Versus Time in Days for Materials in a $375 \mathrm{mg} / \mathrm{L} \mathrm{H}_{2} \mathrm{SO}_{4} 110 \mathrm{mg} / \mathrm{L} \mathrm{HCl} 2.3 \mathrm{mg} / \mathrm{L} \mathrm{HNO}$ Solution at $54^{\circ} \mathrm{C}$. This is the Same Plot as Figure $8 \mathrm{a}$, but the Axis is adjusted to Show Details of Some of the Samples.

A8c Plot of Thickness Loss in mm Versus Time in Days for Materials in a $375 \mathrm{mg} / \mathrm{L} \mathrm{H}_{2} \mathrm{SO}_{4} 110 \mathrm{mg} / \mathrm{L} \mathrm{HCl} 2.3 \mathrm{mg} / \mathrm{L} \mathrm{HNO}$ Solution at $54^{\circ} \mathrm{C}$ Tested a Second Time to Confirm Trends.

A9 Plot of Thickness Loss in mm Versus Time in Days for Materials in a $2000 \mathrm{mg} / \mathrm{L} \mathrm{H}_{2} \mathrm{SO}_{4} 110 \mathrm{mg} / \mathrm{L} \mathrm{HCl}$ Solution at $65.5^{\circ} \mathrm{C}$.

A10a Plot of Weight Change Versus Time in Days for the Ruby Red and MP501 Coatings in the $375 \mathrm{mg} / \mathrm{L} \mathrm{H}_{2} \mathrm{SO}_{4}\left(54^{\circ} \mathrm{C}\right)$ and $2000 \mathrm{mg} / \mathrm{L} \mathrm{H}_{2} \mathrm{SO}_{4}\left(65.5^{\circ} \mathrm{C}\right)$ Solutions.

A10b Plot of Weight Change Versus Time in Days for the Ruby Red and MP501 Coatings in the 65 Percent $\mathrm{H}_{2} \mathrm{SO}_{4}\left(50^{\circ} \mathrm{C}\right)$ and 70 Percent $\mathrm{H}_{2} \mathrm{SO}_{4}\left(85^{\circ} \mathrm{C}\right)$ Solutions. 


\section{EXECUTIVE SUMMARY}

Coal-fired power plants have traditionally operated with stack temperatures in the $300^{\circ} \mathrm{F}$ range to minimize acid corrosion and provide a buoyancy force to assist in the transport of flue gas up the stack. However, as an alternative, there would be benefits to cooling the flue gas to temperatures below the water vapor dew point. The condensed water vapor would provide a source of water for use in power plant cooling; recovered latent and sensible heat could be used to reduce unit heat rate; the reduced flue gas temperature would promote increased mercury removal; and the availability of low-temperature flue gas with reduced acid and water vapor content would reduce the costs of capturing $\mathrm{CO}_{2}$ in back end amine and ammonia $\mathrm{CO}_{2}$ scrubbers.

This report, which is the final technical report for DOE project DE-NT0005648, describes the continued development of condensing heat exchanger technology for coal-fired boilers. In particular, the report describes results of slip stream tests performed at coal-fired power plants, theoretical predictions for acid concentrations in liquid deposits at surface temperatures above the water vapor dewpoint temperature, laboratory corrosion data on candidate tube materials, data on the effectiveness of acid traps in reducing sulfuric acid concentrations in heat exchanger tube bundles, designs of full scale heat exchangers and installed capital costs, condensed water treatment needs and costs, and results of cost-benefit studies of condensing heat exchangers.

Power Plant Slip Stream Tests. An expanded data base on water and acid condensation characteristics of boiler flue gas with water-cooled condensing heat exchangers was generated from slip stream tests at coal-fired power plants. The units included one which fires high sulfur bituminous coal and has a wet FGD scrubber and two which are unscrubbed and fire high-moisture low rank coals. In the case of the two unscrubbed units, the flue gas slip streams were obtained from flue gas ducts downstream of the ESP's, while the flue gas slip stream from the third boiler was taken just downstream of the wet FGD. The results show strong dependence of total heat transfer and water vapor capture efficiency on flow rate ratio of cooling water to flue gas and inlet cooling water temperature. If cold boiler feedwater is used as the cooling fluid, the flow rate ratio of cooling water to flue gas will be approximately 0.5 and water vapor capture efficiencies will be limited to approximately 20 percent. For applications in which flow rates of cooling water greater than the flow rate of cold boiler feedwater are available, water vapor capture efficiencies significantly greater than 20 percent will be possible.

As boiler flue gas is reduced in temperature below the sulfuric acid dew point, the acid first condenses as a highly concentrated solution of sulfuric acid and water. Based on thermodynamic liquid-vapor phase equilibrium calculations for sulfuric acid-water mixtures, concentrations of sulfuric acid in the condensate will depend on vapor phase $\mathrm{H}_{2} \mathrm{SO}_{4}$ and $\mathrm{H}_{2} \mathrm{O}$ concentrations and will range from 75 to 85 weight percent.

Depending on coal moisture content, flue gas from coal-fired boilers has water

vapor dewpoint temperatures from 100 to $135^{\circ} \mathrm{F}$. For those applications in which the 
flue gas temperature is reduced to temperatures below the water vapor dewpoint, the liquid mixture of water and sulfuric acid which forms is several orders of magnitude more dilute in sulfuric acid than the highly concentrated acid solutions which form at temperatures above the water vapor dewpoint temperature, but below the sulfuric acid dew point temperature. Both $\mathrm{HCl}$ and $\mathrm{HNO}_{3}$ condense at temperatures less than $140^{\circ} \mathrm{F}$ and their concentrations in low temperature aqueous condensate are significantly lower than those of $\mathrm{H}_{2} \mathrm{SO}_{4}$.

Flue gas mercury measurements showed that vapor phase mercury decreased by 60 percent between the inlet and exit of the heat exchanger system at one unit and from 30 to 80 percent at the second, with the percentage capture increasing as the flue gas exit temperature decreased.

Laboratory Corrosion Tests. Laboratory corrosion tests, designed to simulate the corrosive condensate solutions encountered in the slip stream field tests, were conducted to identify materials which would have adequate service life. The tests were performed in aqueous solutions containing sulfuric acid at concentration levels representative of both dilute and high acid concentration conditions. All materials tested except carbon steel exhibited acceptable corrosion rates in dilute acid solutions. Of the remaining alloys, 304 stainless steel was found to be the preferred choice due to relatively low cost, ease of fabrication, and negligible corrosion rates over the entire range of test conditions.

Alloys 22 and 690 along with two Teflon materials (FEP and PTFE) showed the best performance at high acid concentration conditions. Of these, Alloy 22 is preferred for service in high acid concentrations due to its low corrosion rate, high yield strength and thermal conductivity, and ability to be readily fabricated.

Effectiveness of Acid Traps. Tests were performed to assess the potential of reducing the flue gas sulfuric acid concentration entering the heat exchangers through use of additional surface area in the inlet region to capture a portion of the inlet $\mathrm{H}_{2} \mathrm{SO}_{4}$. The concept involves use of a section of inlet duct filled with closely spaced vertical flat plates aligned parallel to the flow direction (referred to as "acid traps" in this report). The test results show that at temperatures above the water vapor dewpoint, the acid traps reduced the vapor phase acid concentrations entering the heat exchangers just downstream of the traps by 10.2 to 13.7 percent. At temperatures at or below the water vapor dew point, the presence of an acid trap reduced the sulfuric acid flux on the heat exchanger positioned just downstream of the trap by 33 to 42 percent.

Design of Full-Scale Heat Exchangers. Heat exchanger design calculations were made to estimate how much flue gas moisture it would be possible to recover from boiler flue gas, the size and cost of the heat exchangers, and flue gas and cooling water pressure drops. The laboratory corrosion test data showed that at locations in the flue gas upstream of the water vapor dewpoint, the choice of tube material is between Teflon and Alloy 22. The design analyses showed that in order to transfer the same amount of heat, the Teflon heat exchanger would need to have approximately three 
times the surface area of an Alloy 22 heat exchanger, and this would also result in larger pump and fan power requirements than would be needed for the Alloy 22 heat exchanger. As a consequence, the total annual costs for a Teflon heat exchanger would be greater than for a heat exchanger fabricated from Alloy 22.

Because of its corrosion resistance in aqueous solutions with low acid concentrations, relatively low cost and high tensile strength and thermal conductivity, 304 SS is the preferred choice for heat exchanger tubing at temperatures below the water vapor dew point.

There will be separate applications for condensing heat exchangers, depending on coal type. A boiler firing a Powder River Basin coal may not need a wet $\mathrm{SO}_{2}$ scrubber, and in this case, the flue gas temperature at the inlet of the condensing heat exchanger will be in the $300^{\circ} \mathrm{F}$ range with inlet water vapor concentrations of approximately 12 volume percent. For those applications in which a wet FGD is needed for $\mathrm{SO}_{2}$ control (bituminous coals and some lignites typically require wet FGD's), the flue gas entering the condensing heat exchanger will be saturated with water vapor and have a temperature ranging from 125 to $135^{\circ} \mathrm{F}$, with the temperature depending on coal moisture content.

Treatment of Condensed Water. Ion exchange and reverse osmosis technologies were evaluated for treatment of condensed water from flue gas water recovery heat exchangers, with the goal of using the recovered water as cooling tower makeup water. Comparisons of the chemical composition of condensed water with cooling tower water, makeup water, and river water samples reveal that they are comparable except for nitrate, sulfate, iron and $\mathrm{pH}$ level. An ion exchange system is recommended for this application, and cost analysis of the ion exchange system revealed that the cost of water treatment would be approximately $\$ 0.001 /$ gallon.

Cost-Benefit Analyses. Estimates of the costs and benefits of utilizing heat exchangers to cool boiler flue gas to temperatures below the water vapor dewpoint were made for three cases. The analyses assume the condensed water is treated and the heat captured from the flue gas is used to preheat boiler feedwater.

Case 1 involves a heat exchanger installed downstream of a wet FGD and Case 2 involves an unscrubbed PRB-fired unit with the heat exchanger having $300^{\circ} \mathrm{F}$ inlet and $120^{\circ} \mathrm{F}$ exit flue gas temperatures. Case 3 also involves an unscrubbed PRB-fired unit, but with the heat exchanger having $300^{\circ} \mathrm{F}$ inlet and $214^{\circ} \mathrm{F}$ exit flue gas temperatures. In all three cases, the cooling water for the condensing heat exchanger is cold boiler feedwater which enters the heat exchanger at $87^{\circ} \mathrm{F}$ with a flow rate which is 50 percent of the flue gas flow rate.

Estimates of heat exchanger capital costs were made and these were converted into annual fixed charges for the three cases. Both the cooling water and flue gas experience pressure drops as they flow through the heat exchanger and the additional power needed for the ID fan and feedwater pump are included in the analyses as 
operating costs. The annual fixed charges and annual O\&M costs for ion exchange systems are also included in the cost-benefit analyses.

The benefits include increased turbine power, credit for reduced external water consumption and credit for reduced emissions of mercury and sulfuric, hydrochloric and nitric acids. For these analyses, no dollar amounts were placed on the value of avoided stack emissions.

The results suggest that condensing heat exchangers installed downstream of wet FGD's would be cost effective. The benefits would include capture of water from flue gas for use within the power plant and increase in net unit power output. Estimated annual benefits are $\$ 1.304$ million vs. costs of $\$ 0.793$ million. The results also show that condensing heat exchangers for use upstream of wet FGD's or at units which do not have wet scrubbers may be cost effective if they are designed to cool flue gas to intermediate temperatures. Such a design strategy would restrict heat exchanger annual costs to levels below the financial benefit derived from increased power generation obtained from using flue gas heat to preheat boiler feedwater. 


\section{CHAPTER 1}

\section{Introduction}

As the U.S. population grows and demand for electricity and water increase, power plants located in some parts of the country will find it increasingly difficult to obtain the large quantities of water needed to maintain operations. Most of the water used in a thermoelectric power plant is used for cooling, and DOE has been focusing on possible techniques to reduce the amount of fresh water needed for cooling. DOE has also been placing emphasis on recovery of usable water from sources not generally considered, such as mine water, water produced from oil and gas extraction, and water contained in boiler flue gas.

The moisture in boiler flue gas comes from three sources ... fuel moisture, water vapor formed from the oxidation of fuel hydrogen, and water vapor carried into the boiler with the combustion air. The amounts of $\mathrm{H}_{2} \mathrm{O}$ vapor in flue gas depend heavily on coal rank. Calculation of typical coal flow rates and flue gas moisture flow rates for $600 \mathrm{MW}$ pulverized coal power plants show that flue gas moisture flow rates range from approximately 225,000 to more than $650,000 \mathrm{lbs} / \mathrm{hr}$. In contrast, typical cooling tower water evaporation rates for a $600 \mathrm{MW}$ unit are 2.1 million lbs/hr. Thus, coal-fired power plants, equipped with a means of extracting all the flue gas moisture and using it for cooling tower makeup, would be able to supply from 10 percent to 33 percent of the makeup water by this approach (Table 1-1).

Table 1-1: Estimated Fractions of Cooling Tower Makeup Water Provided by Condensing Heat Exchangers, Assuming 100 Percent Water Vapor Capture

\begin{tabular}{|l|c|c|}
\hline \multicolumn{1}{|c|}{ Case } & $\begin{array}{c}\text { Inlet Flue Gas Moisture Fraction } \\
\text { (Volume Percentage) }\end{array}$ & $\begin{array}{c}\text { Maximum } \mathrm{H}_{2} \mathbf{O} \\
\text { Capture/Makeup } \mathrm{H}_{2} \mathbf{O}\end{array}$ \\
\hline Bituminous (Unscrubbed) & $6-8$ & $0.10-0.13$ \\
\hline Bituminous (Wet FGD) & $16-17$ & $0.30-0.33$ \\
\hline PRB (Unscrubbed) & $10.5-12$ & $0.19-0.22$ \\
\hline $\begin{array}{l}\text { High Moisture Lignite } \\
\text { (Unscrubbed) }\end{array}$ & $15.5-16.5$ & $0.29-0.31$ \\
\hline Lignite (Wet FGD) & 17.5 & $0.33-0.34$ \\
\hline
\end{tabular}


Many coal-fired power plants operate with stack temperatures in the $300^{\circ} \mathrm{F}$ range to minimize fouling and corrosion problems due to sulfuric acid condensation and to provide a buoyancy force to assist in the transport of flue gas up the stack. With $\mathrm{SO}_{3}$ concentrations up to $35 \mathrm{ppm}$, sulfuric acid begins condensing at temperatures from 250 to $310^{\circ} \mathrm{F}$ (Figure 1-1), and with flue gas water vapor volume concentrations typically from 6 to 17.5 volume percent, depending on coal rank, the water vapor dewpoint is usually in the 100 to $135^{\circ} \mathrm{F}$ range (Figure 1-2). Other acids (hydrochloric, and nitric, for example) condense in the same temperature range as $\mathrm{H}_{2} \mathrm{O}$ (Figure 1-3).

There would be significant benefits to cooling the flue gas to temperatures below the water vapor and acid dew points, provided the acid corrosion problems can be overcome in a cost-effective way. With stack temperatures below the water vapor dew point, condensed water vapor would provide a source of water for use in power plant cooling; recovered latent and sensible heat from the flue gas could be used to reduce unit heat rate and thereby reduce $\mathrm{CO}_{2}$ emissions; condensation of acid in a controlled manner would reduce the flue gas acid content and provide environmental, operational and maintenance benefits; the reduced flue gas temperature would promote increased mercury removal; and the availability of low temperature flue gas with reduced acid and water vapor content would reduce the costs of capturing $\mathrm{CO}_{2}$ at the back end of the boiler.

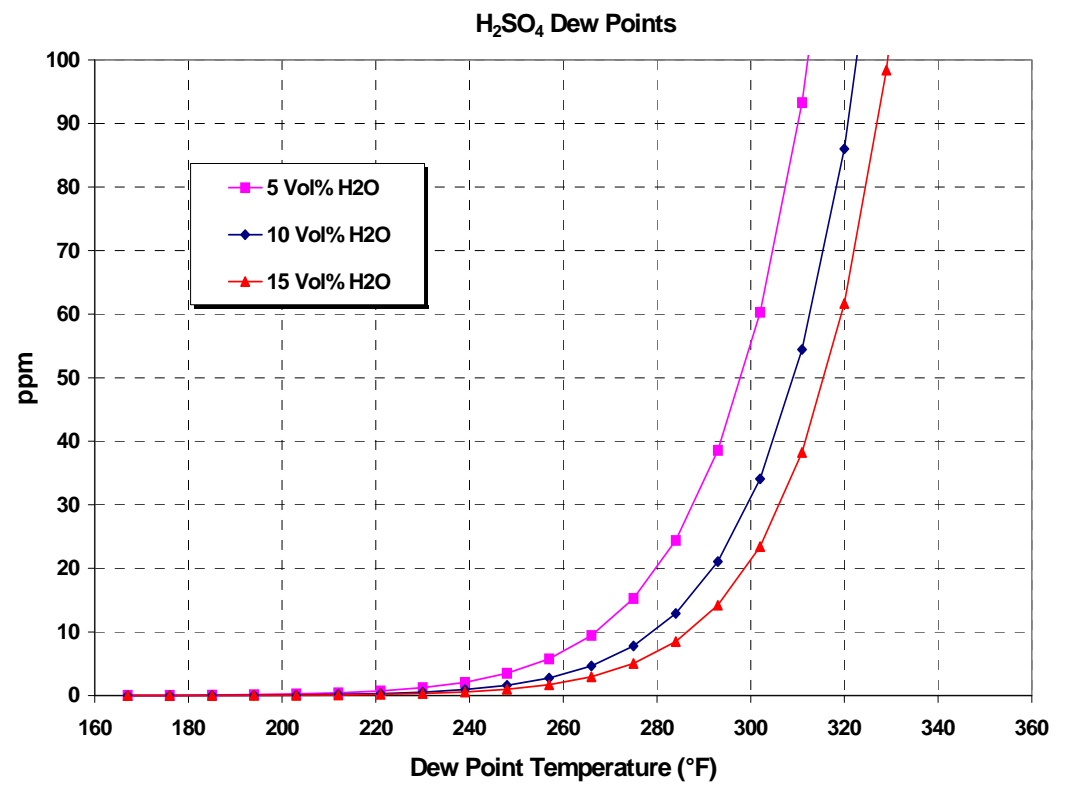

Figure 1-1: Sulfuric Acid Dew Point Temperature vs. Acid Concentration (Refs. 1 to 4) 


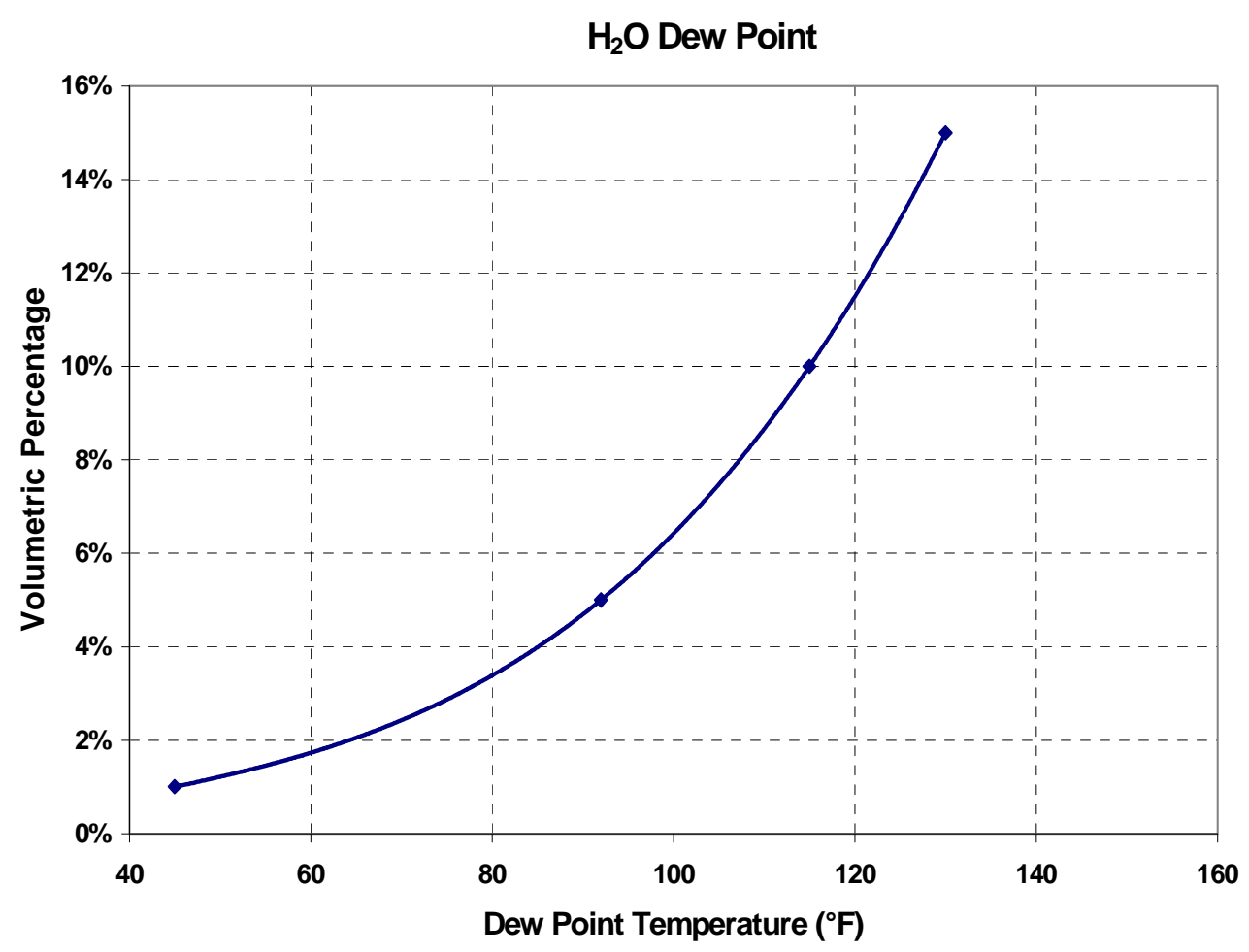

Figure 1-2: Water Vapor Dew Point vs. Volumetric Concentration (Ref 5)

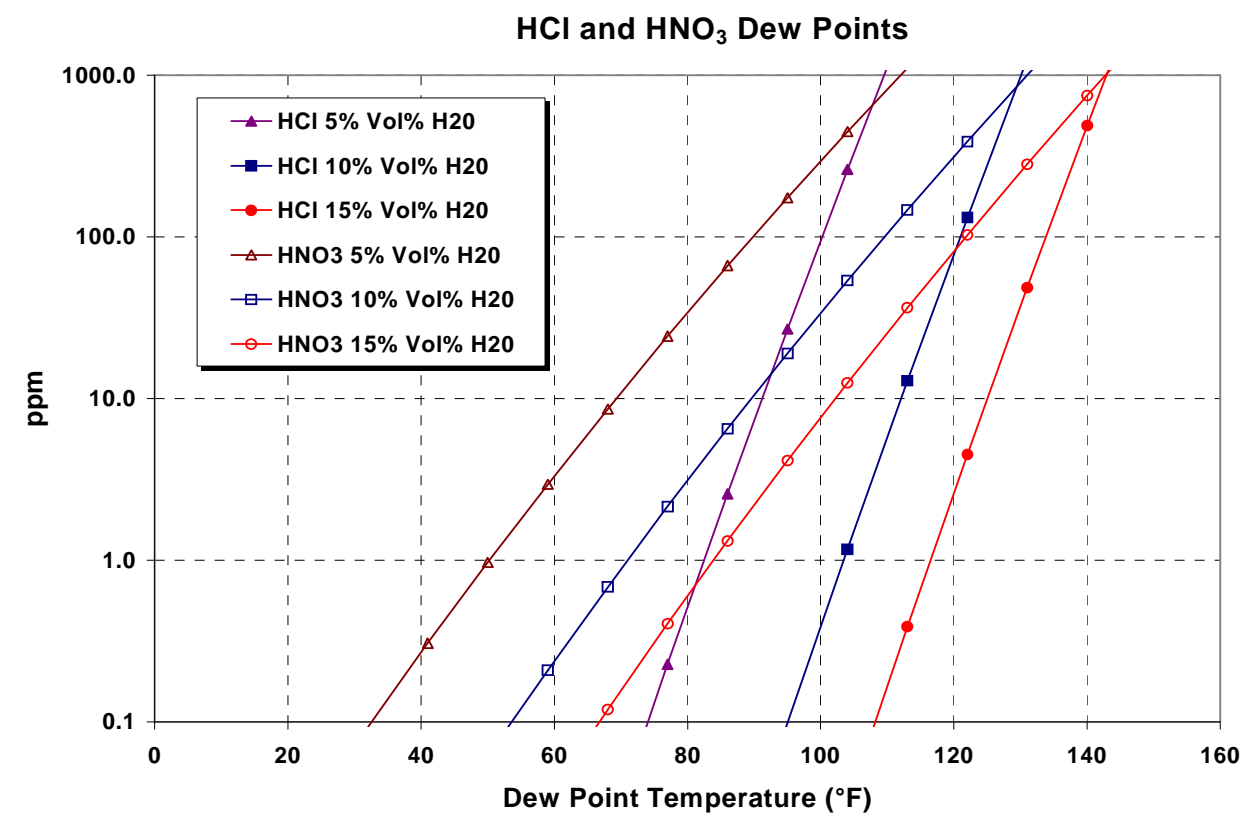

Figure 1-3: Dew Point Temperatures of Hydrochloric and Nitric Acids (Ref 6 and 7)

Under DOE project DE-FC26-06NT42727, "Recovery of Water from Boiler Flue Gas," Lehigh University investigated the heat transfer and water vapor and acid condensation characteristics of condensing heat exchangers (Ref. 8). The present 
report, which is the final technical report for DOE project DE-NT0005648, describes the continued development of condensing heat exchanger technology for coal-fired boilers. In particular, the report describes:

- An expanded data base on water and acid condensation characteristics of condensing heat exchangers in coal-fired units. This data base was generated by performing slip stream tests at a power plant with high sulfur bituminous coal and a wet FGD scrubber and at a power plant firing highmoisture, low rank coals (Chapter 2).

- Data on typical concentrations of $\mathrm{HCl}, \mathrm{HNO}_{3}$ and $\mathrm{H}_{2} \mathrm{SO}_{4}$ in low temperature condensed flue gas moisture (Chapter 2).

- Theoretical predictions for sulfuric acid concentrations on tube surfaces at temperatures above the water vapor dewpoint temperature, and below the sulfuric acid dew point temperature (Chapter 3 ).

- Data on corrosion rates of candidate heat exchanger tube materials for the different regions of the heat exchanger system as functions of acid concentration and temperature (Chapter 4).

- Data on effectiveness of acid traps in reducing sulfuric acid concentrations in a heat exchanger tube bundle. Mercury capture efficiencies as functions of process conditions in power plant field tests (Chapter 5).

- Condensing heat exchanger designs and installed capital costs for full scale applications, both for installation immediately downstream of an ESP or baghouse and for installation downstream of a wet $\mathrm{SO}_{2}$ scrubber (Chapter 6).

- Condensed flue gas water treatment needs and costs (Chapter 7).

- Results of cost-benefit studies of condensing heat exchangers (Chapter 8).

\section{References}

1. Rylands, J. R., and J. R. Jenkinson, "The Acid Dewpoint," Journal of the Institute of Fuel, Vol. 27, 1954, pp. 299-309.

2. Gmitro, J. I., and T. Vermeulen, "Vapor-Liquid Equilibria for Aqueous Sulfuric Acid," AlChE Journal, Vol. 10, 1964, pp. 740-746.

3. Halstead, W. D., "The Sulfuric Acid Dewpoint in Power Station Flue Gases," Journal of the Institute of Energy, Vol. 53, September 1980, pp. 142-145. 
4. Banchero, J. T., and F. H. Verhoff, "Evaluation and Interpretation of the Vapour Pressure Data for Sulfuric Acid Aqueous Solutions with Applications to Flue Gas Dewpoints," Journal of the Institute of Fuel, Vol. 48, 1975, pp. 76-80.

5. Thermodynamic Properties of Steam, J. Keenan and F. Keyes. John Wiley. 1936.

6. Verhoff, F. H. and J. T. Banchero, "Predicting Dew Points of Flue Gases," Chem. Eng. Progress, 1974, Vol. 70, pp. 71-72.

7. Yen Hsiung Kiang, "Predicting Dewpoints of Acid Gases," Chemical Engineering, February 9, 1981, p. 127.

8. Levy, E. et al, "Recovery of Water from Boiler Flue Gas," Final Technical Report for DOE Project DE-FC26-06NT42727, December, 2008. 


\section{CHAPTER 2}

\section{POWER PLANT SLIP STREAM TESTS OF HEAT EXCHANGERS}

\section{Introduction}

This chapter describes the results of slipstream heat transfer and water vapor condensation tests performed at three coal-fired power plants. In addition, data are presented on rates of acid condensation on the heat exchangers and on the effects of the heat exchangers on flue gas mercury content.

\section{Flue Gas and Cooling Water Conditions}

The heat exchanger applications described in this Chapter are for two distinct flue gas process conditions. For a coal-fired unit without a wet FGD, the heat exchanger system would be located downstream of the ESP or baghouse and would cool the flue gas to temperatures below the water vapor dew point temperature. Inlet flue gas moisture concentration will depend on coal type, and will range from approximately 6 to 8 volumetric percent for bituminous coal to values of 12 to13 percent for North American lignites. In the case of a unit with a wet FGD, the possibility exists for heat exchangers to be located both upstream and downstream of the FGD. Flue gas exiting the $\mathrm{FGD}$ is typically in the $125^{\circ} \mathrm{F}$ to $140^{\circ} \mathrm{F}$ temperature range and is saturated with water vapor. A heat exchanger located upstream of the FGD would capture sensible heat and a heat exchanger located downstream of the FGD would both cool the flue gas (sensible heat transfer) and condense water vapor from the flue gas (latent heat transfer). Figure 2-1 shows the relationship between water vapor dewpoint temperature and volume concentration for flue gas at atmospheric pressure.

In addition to water vapor, flue gas from coal contains sulfuric, hydrochloric and nitric acids. Typical flue gas sulfuric acid concentrations range from a few ppm to values in excess of $40 \mathrm{ppm}$. Sulfuric acid dew point temperature depends on both sulfuric acid and water vapor concentrations, with dew point temperatures ranging from 


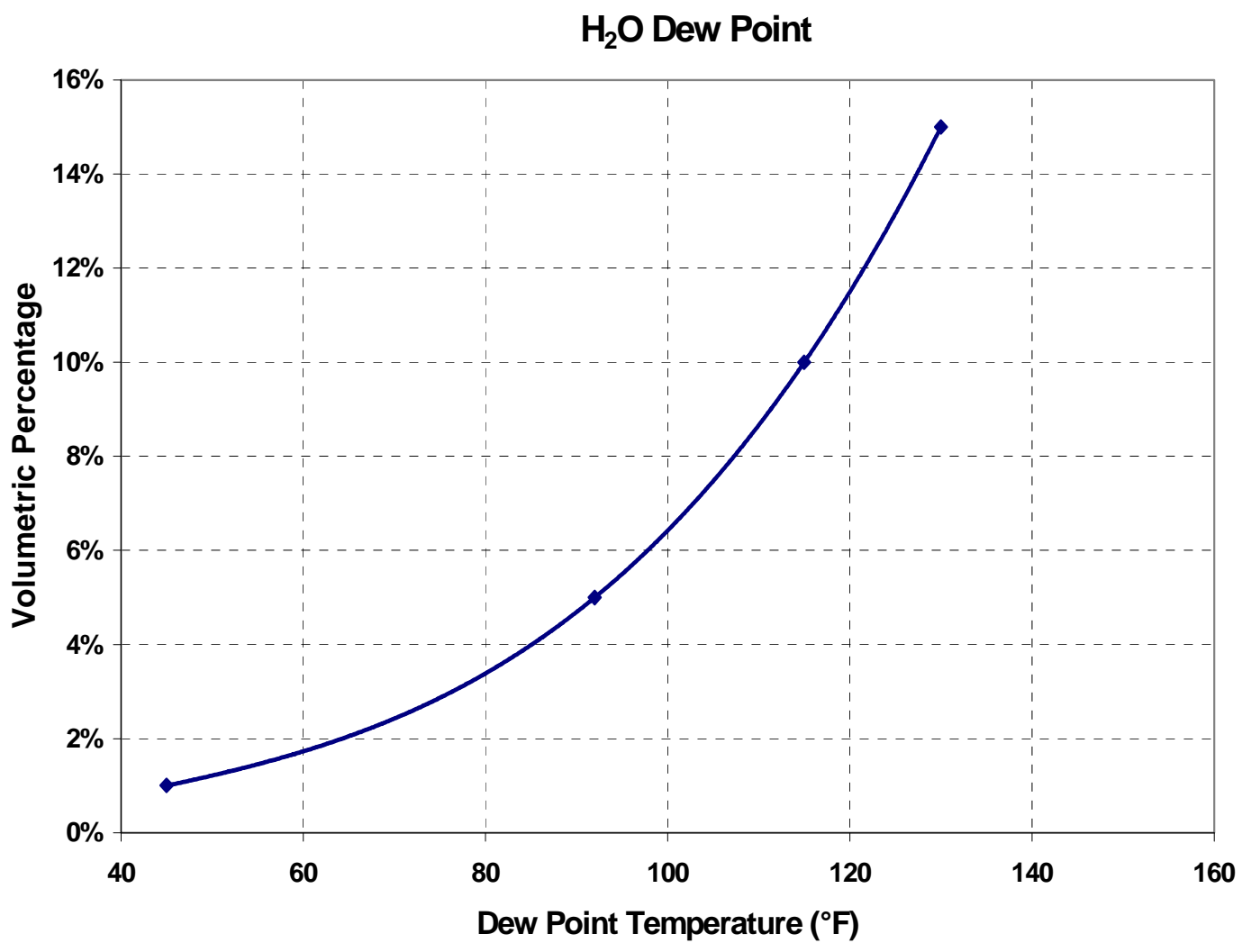

Figure 2-1: Water Vapor Dewpoint Temperature vs. Volumetric Concentration

approximately $310^{\circ} \mathrm{F}$ at $50 \mathrm{ppm} \mathrm{H}_{2} \mathrm{SO}_{4}$ to approximately $250^{\circ} \mathrm{F}$ at $1 \mathrm{ppm}$ (Figure 2-2) (Ref. 1). At sufficiently high concentrations, hydrochloric and nitric acids begin condensing at temperatures approaching $140^{\circ} \mathrm{F}$ (Ref. 2) (Figure 2-3).

The presence of acids is of particular concern for heat exchangers in low temperature flue gas, because of the potential for corrosion of heat exchanger tubes.

\section{Experimental Apparatus and Variables Tested}

The experiments described in this Chapter were performed to measure rates of heat transfer and water vapor condensation in boiler flue gas. In addition, measurements were made to characterize the acid concentrations in the water which condensed on the heat exchanger tubes and to determine the effects of the heat exchangers on flue gas mercury concentrations. 


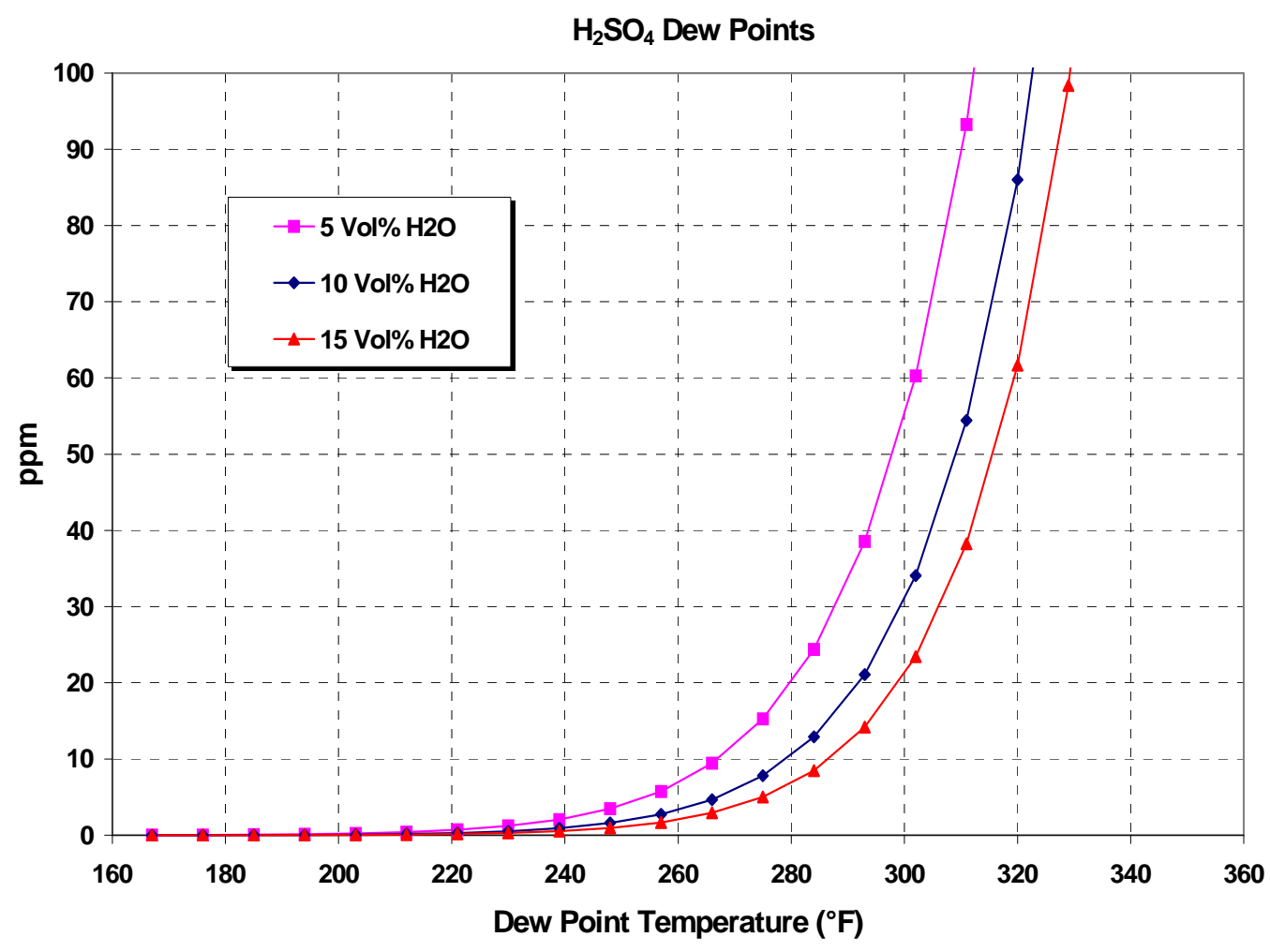

Figure 2-2: Sulfuric Acid Dew Point Temperature vs. Acid Concentration

$\mathrm{HCl}$ and $\mathrm{HNO}_{3}$ Dew Points

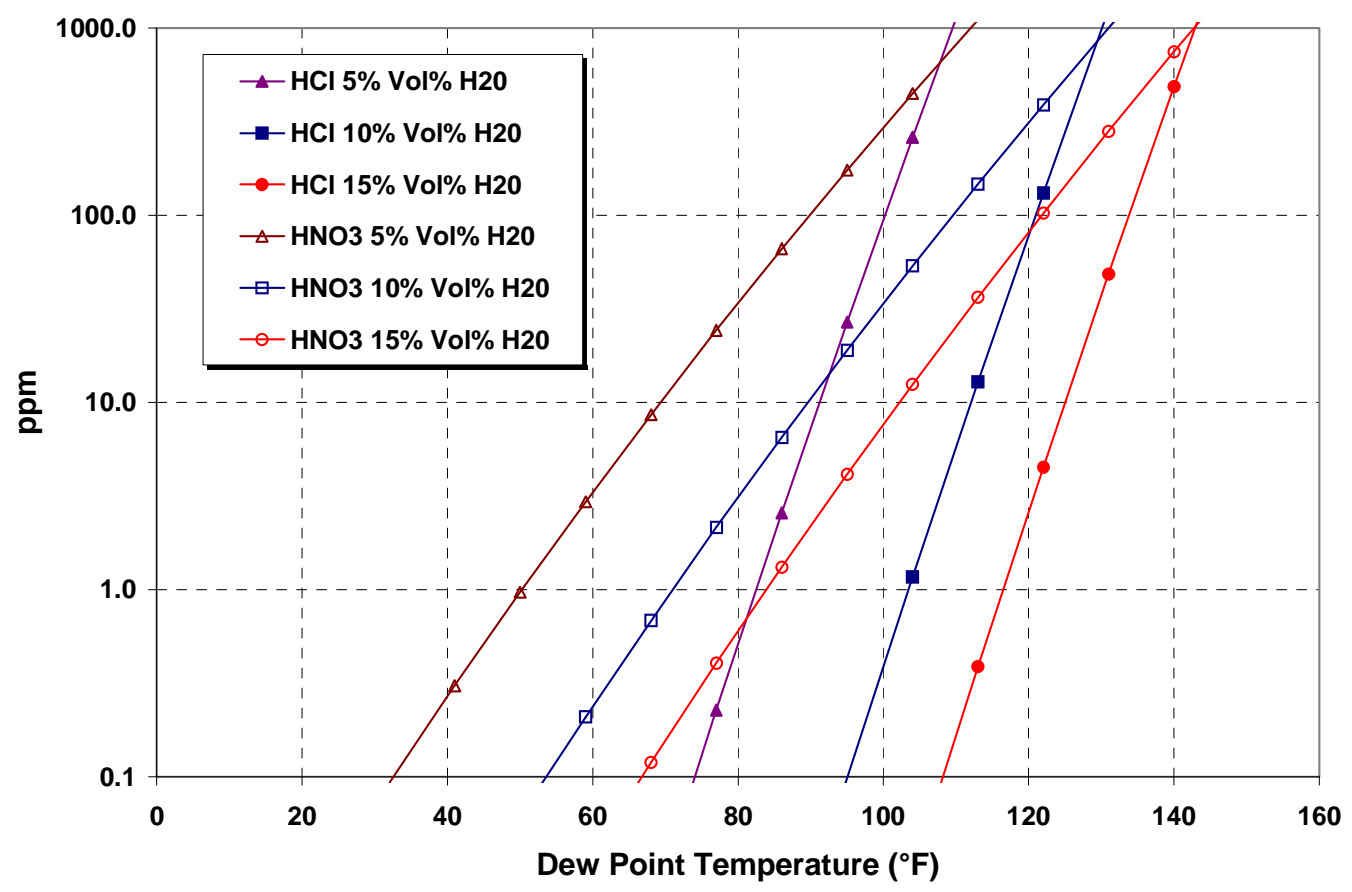

Figure 2-3: Dew Point Temperatures of Hydrochloric and Nitric Acids 
The condensing heat exchanger apparatus used in this project consisted of a rectangular duct containing water-cooled heat exchangers arranged in series (Figure 24). The heat exchangers operated in counterflow, with cooling water flowing through the tubes and flue gas flowing outside of the tubes. The apparatus was instrumented with sensors to measure water and flue gas flow rates; flue gas, cooling water, and tube wall temperatures; and wet bulb and dry bulb temperatures of the flue gas as it exited from the apparatus. Condensed water drained from the heat exchangers into closed containers, with rates of water condensation measured by periodically emptying the containers and weighing the condensate. In addition, the Controlled Condensation method was used during some tests to determine the flue gas $\mathrm{H}_{2} \mathrm{SO}_{4}$ concentrations before and after each of the heat exchangers and sorbent traps were used to measure concentrations of $\mathrm{Hg}$ entering and exiting the heat exchanger assembly.

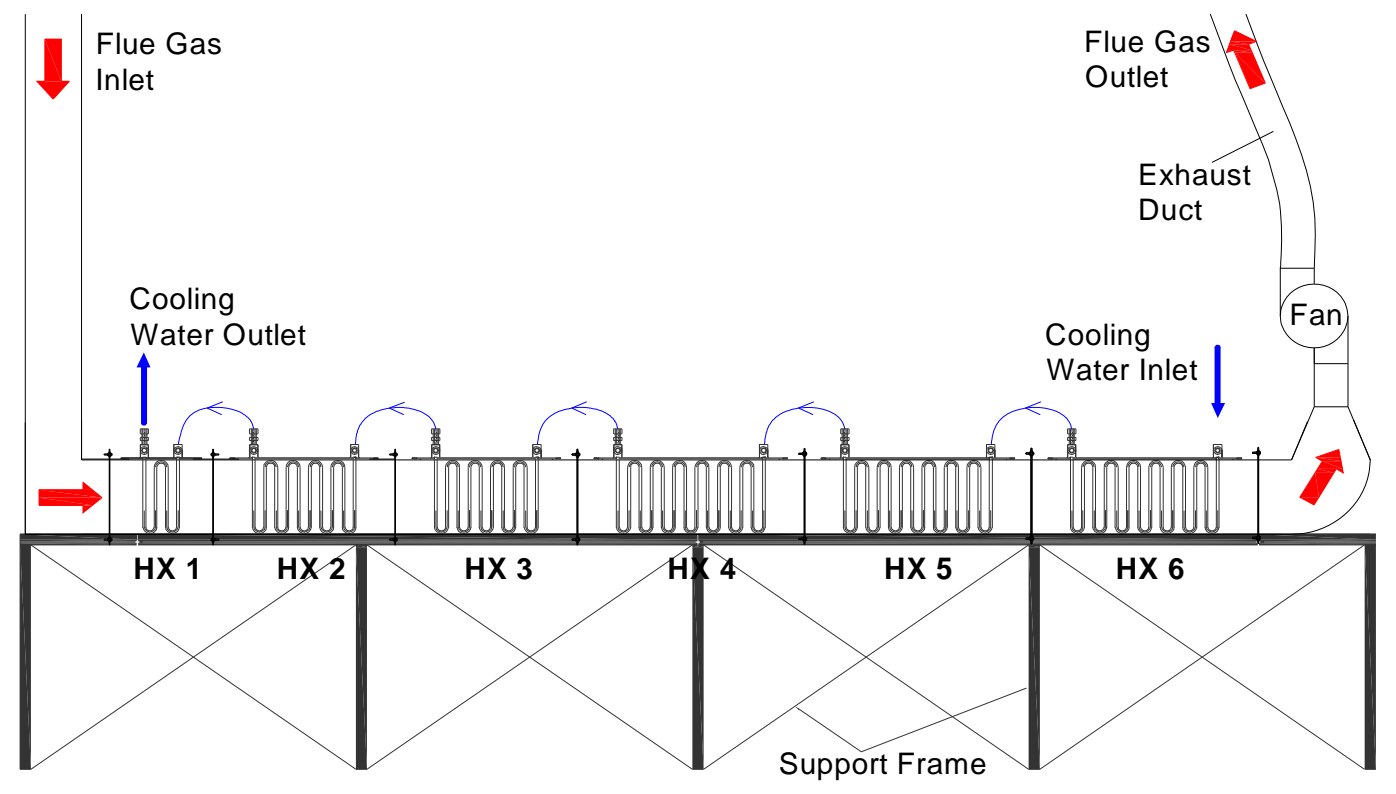

Figure 2-4: Elevation View of Test Apparatus

The results presented here were obtained at three-coal fired units. In two of the cases (Referred to as Units A and B), the slip stream of flue gas was extracted from the flue gas duct downstream of ESP's and in the third case (Unit C), the slip stream of flue gas was extracted from the flue gas duct immediately downstream of a wet FGD. 
The controllable parameters in these tests included cooling water and flue gas flow rates and cooling water temperature. Flue gas inlet temperature and moisture concentration were dictated by the power plant design and operating conditions and coal quality.

\section{Results}

Heat Exchanger Performance. Figures 2-5 and 2-6 illustrate the trends in axial variations of flue gas, tube wall and water vapor dew point temperatures and water vapor condensation rates in Boiler $B$, plotted vs. heat exchanger surface area. There were five heat exchangers with a cumulative surface area of $73 \mathrm{ft}^{2}$ used in this series of tests. The flue gas entered at $297^{\circ} \mathrm{F}$, the inlet cooling water temperature was $93^{\circ} \mathrm{F}$ and the inlet flue gas dew point temperature was $118^{\circ} \mathrm{F}$, which corresponds to an inlet water vapor volume fraction of 10.9 percent. The condensate collection measurements (Figure 2-6) showed that water vapor condensed only in heat exchangers HX3, HX4 and HX5 for the conditions of this data set. This is consistent with the temperature measurements (Figure 2-5), which show that the tube wall temperatures were greater than the water vapor dew point temperature in heat exchangers $\mathrm{HX} 1, \mathrm{HX} 2$ and in part of $\mathrm{HX} 3$ and then equal to the dew point temperatures in HX5, HX4 and part of HX3. Figure 2-7 shows the total heat transfer within the five heat exchangers as a function of the flow rate ratio of cooling water to flue gas. These data show a strong increase in rate of heat transfer as the cooling water to flue gas flow rate ratio increases. The rate of water condensation capture efficiency (Figure 2-8) also depended strongly on cooling water to flue gas flow rate ratio, increasing from approximately 20 percent at $\mathrm{mcw} / \mathrm{mfg}=$ 0.5 to 57 percent at $\mathrm{mcw} / \mathrm{mfg}=2.12$. (Capture efficiency is defined here as the ratio of water vapor condensation rate to the rate at which water vapor enters the heat exchanger system with the flue gas.) 


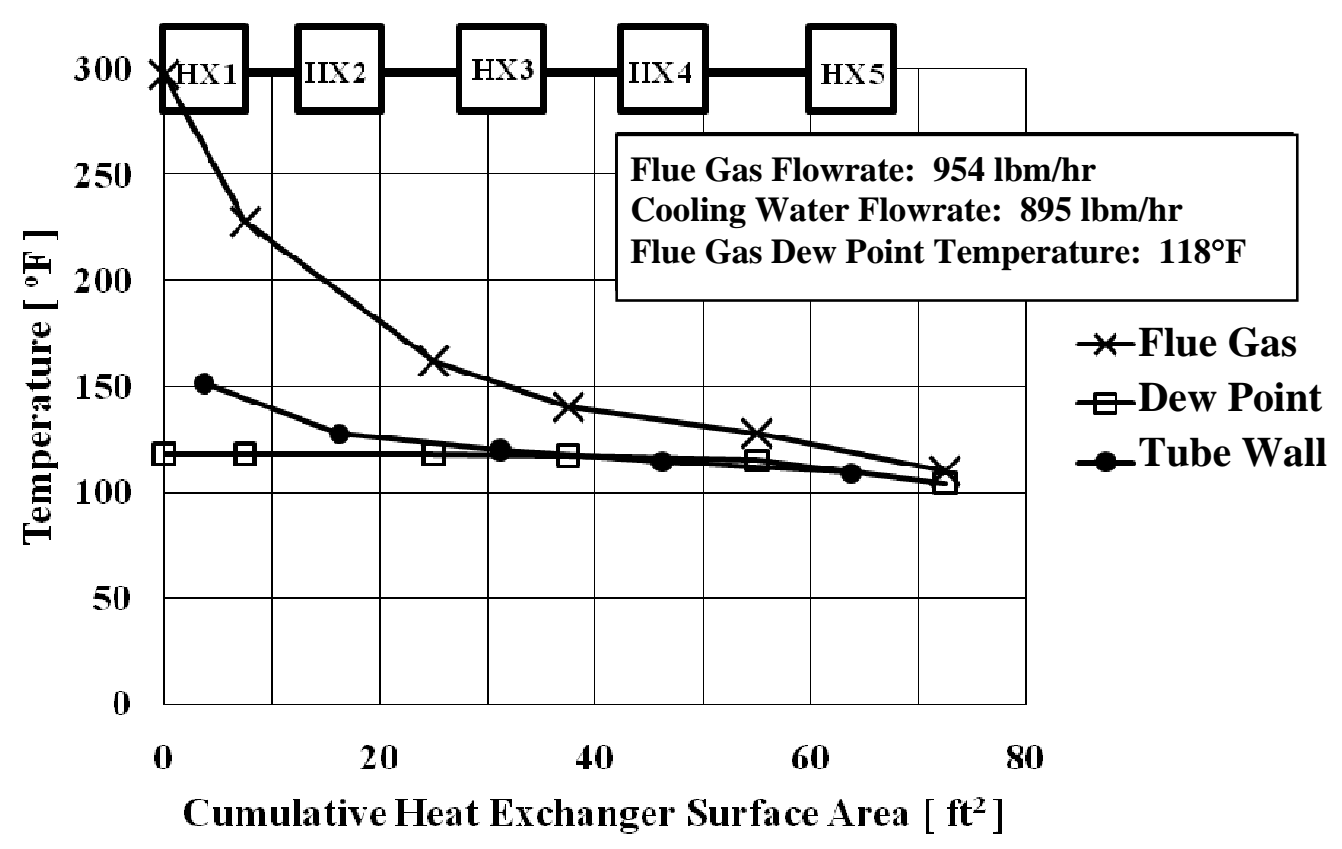

Figure 2-5: Axial Variations of Flue Gas, Water Vapor Dew Point, and Tube Wall Temperatures: Unit B

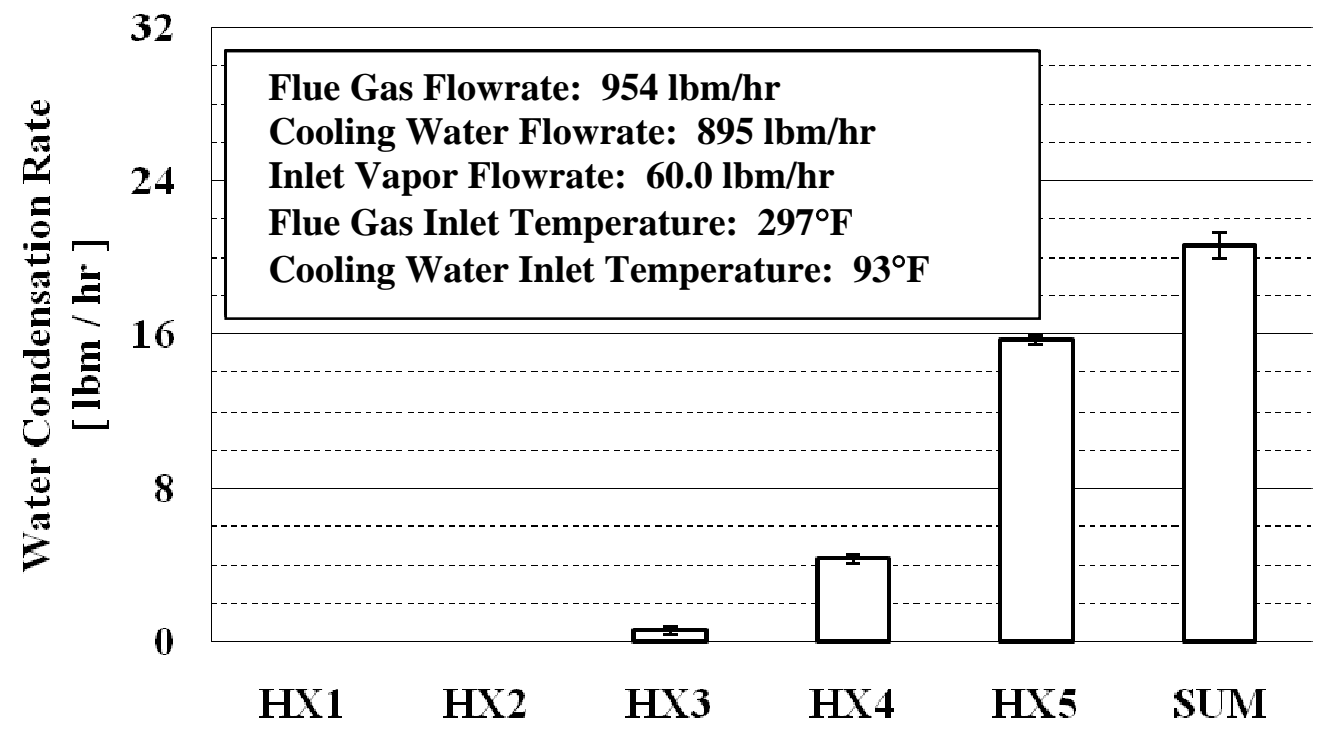

Figure 2-6: Water Vapor Condensation Rates on the Five Heat Exchangers: Unit B 


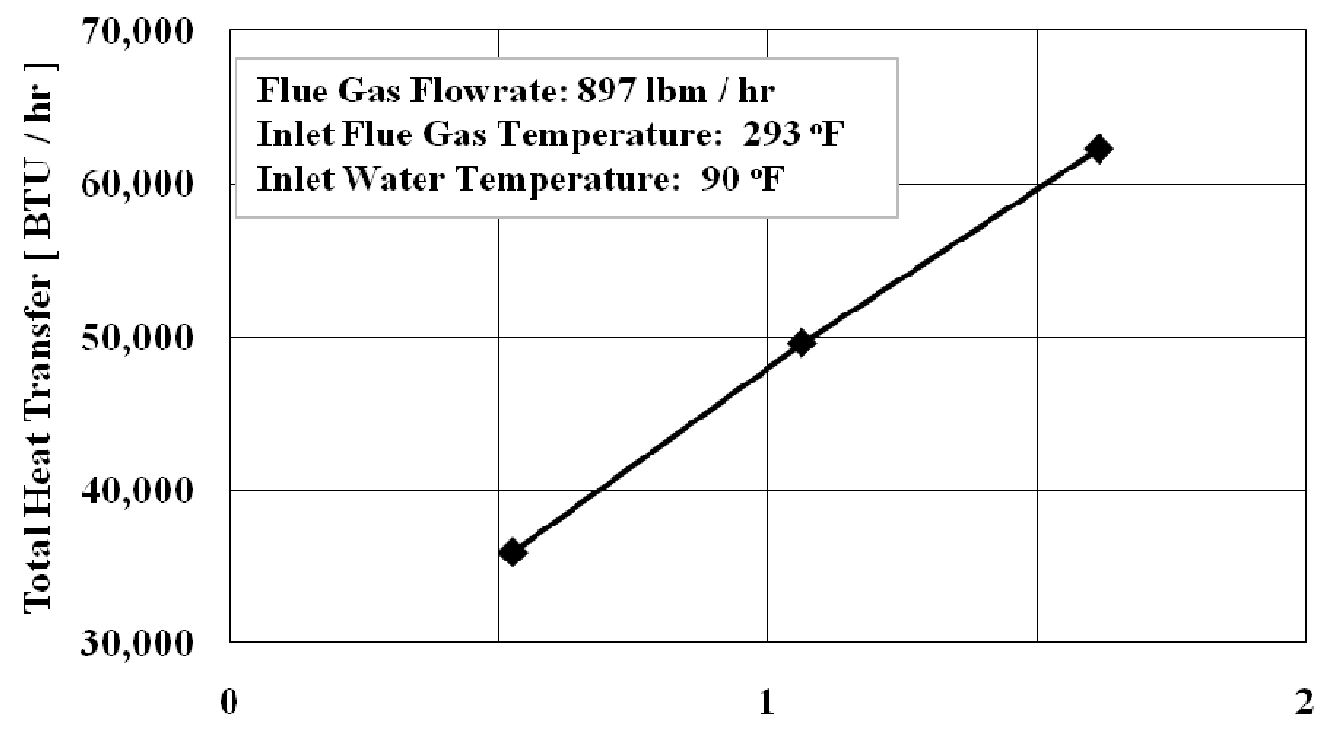

Mcw / Mfg

(flowrate ratio of cooling water-to-flue gas)

Figure 2-7: Variation of Rate of Total Heat Transfer with Cooling Water to Flue Gas Mass Flow Rate Ratio: Unit B

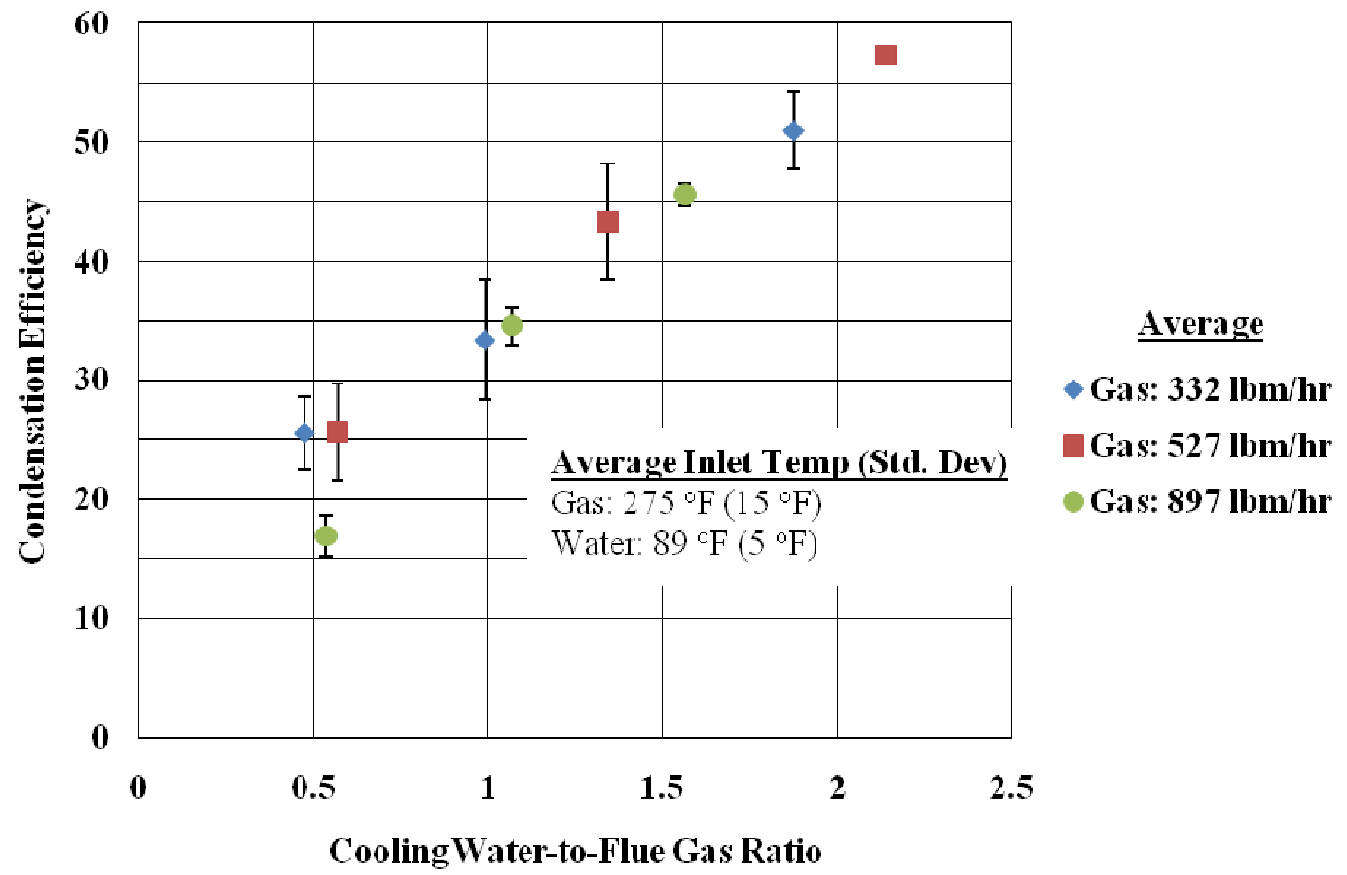

Figure 2-8: Variation of Water Vapor Capture Efficiency with Cooling Water to Flue Gas Mass Flow Rate Ratio: Unit B 
During the tests at Unit $C$, the slip stream of flue gas used in the tests was extracted from the boiler's flue gas duct immediately downstream of the wet FGD. This resulted in flue gas inlet temperatures to the heat exchangers of approximately $123^{\circ} \mathrm{F}$ and inlet flue gas volume concentrations of approximately 12.2 percent. Inlet cooling water temperature was approximately $85^{\circ} \mathrm{F}$. Four heat exchangers, with a cumulative heat exchanger surface area of $56 \mathrm{ft}^{2}$, were used during this sequence of tests, and Figure 2-9 shows typical axial profiles of cooling water and flue gas temperature. The total rate of heat transfer increased by 105 percent and the condensation efficiency increased by 37 percent as the cooling water to flue gas flow rate ratio increased from 0.5 to 1.0 (Figures 2-10 and 2-11). This is similar to the findings for the data from Boiler $B$, where the total rate of heat transfer and the condensation efficiency both increased strongly with increasing values of cooling water to flue gas flow rate ratio.

Cooling water temperature also impacts water vapor condensation efficiency and heat transfer, with both parameters increasing as inlet cooling water temperature decreases (Figure 2-12).

\section{Temperature profiles for $\mathbf{m}_{\mathrm{cw}} / \mathrm{m}_{\mathrm{fg}}=$ $500 / 1000$}

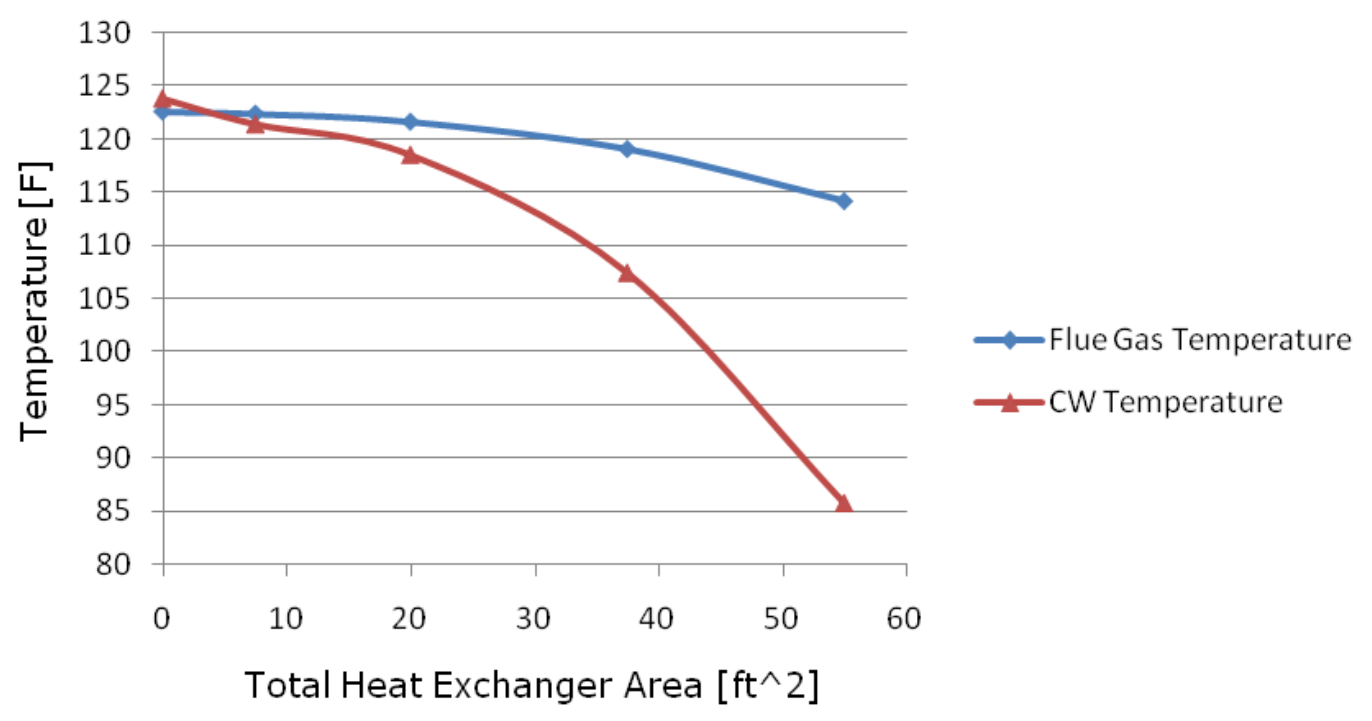

Figure 2-9: Flue Gas and Cooling Water Temperature Profiles: Unit C 


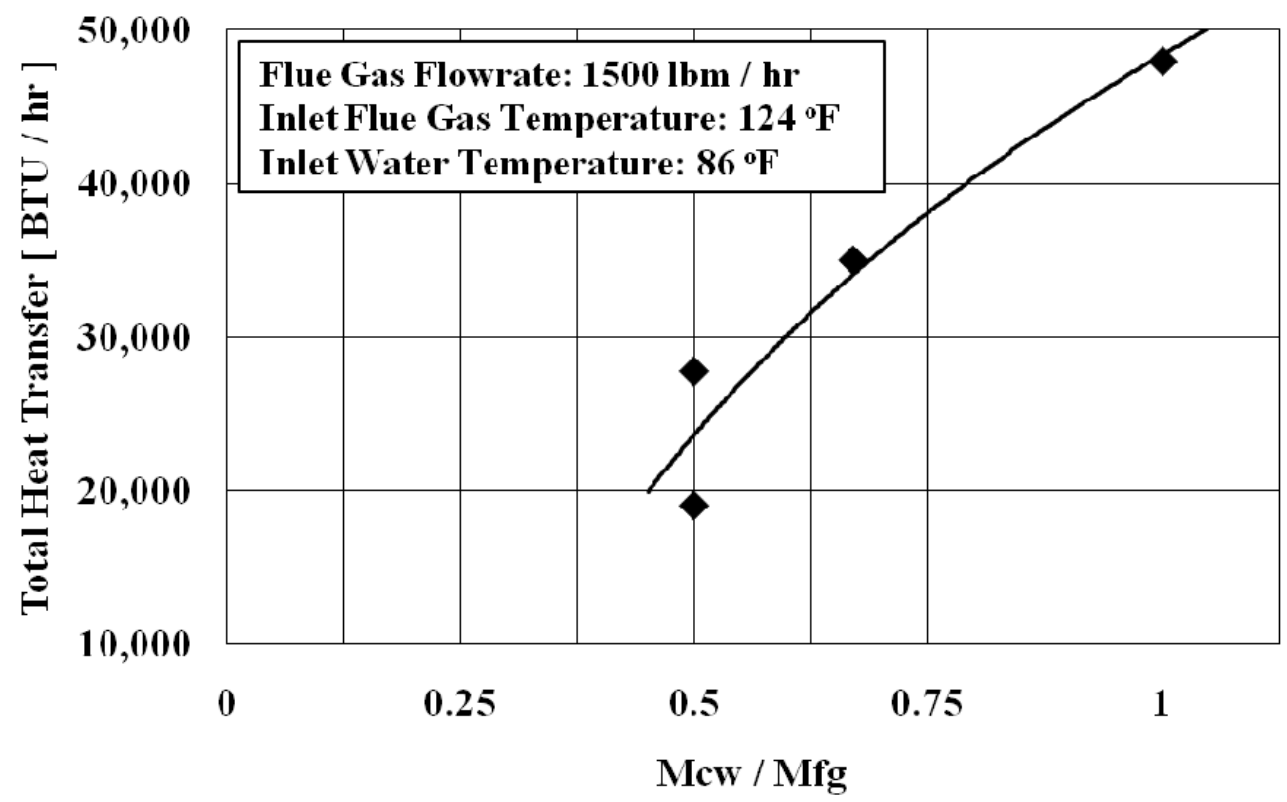

(flowrate ratio of cooling water-to-flue gas)

Figure 2-10: Rate of Total Heat Transfer vs. Ratio of Mass Flow Rate of Cooling Water to Flue Gas: Unit C

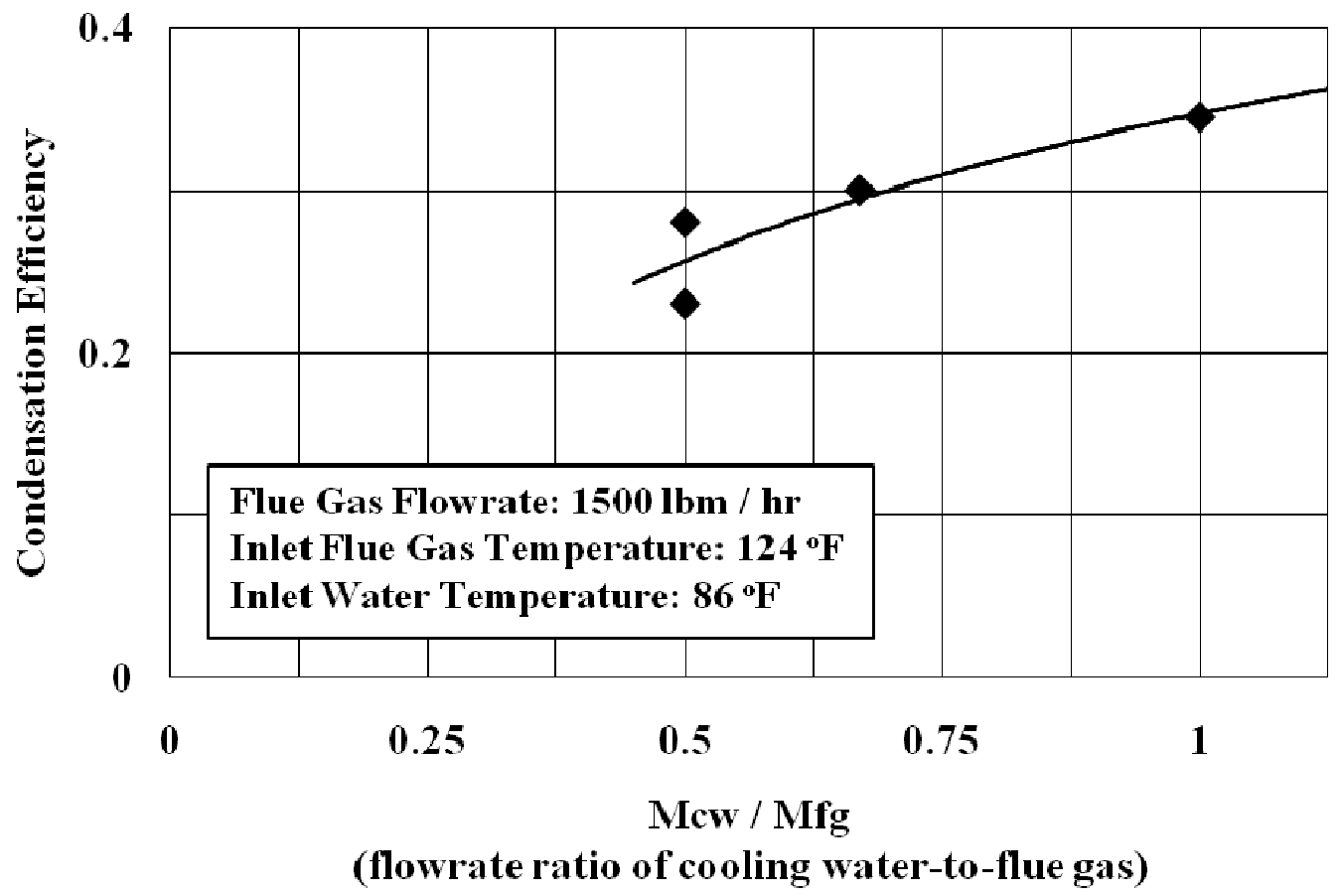

Figure 2-11: Water Vapor Capture Efficiency vs. Ratio of Mass Flow Rate of Cooling Water to Flue Gas: Unit C 


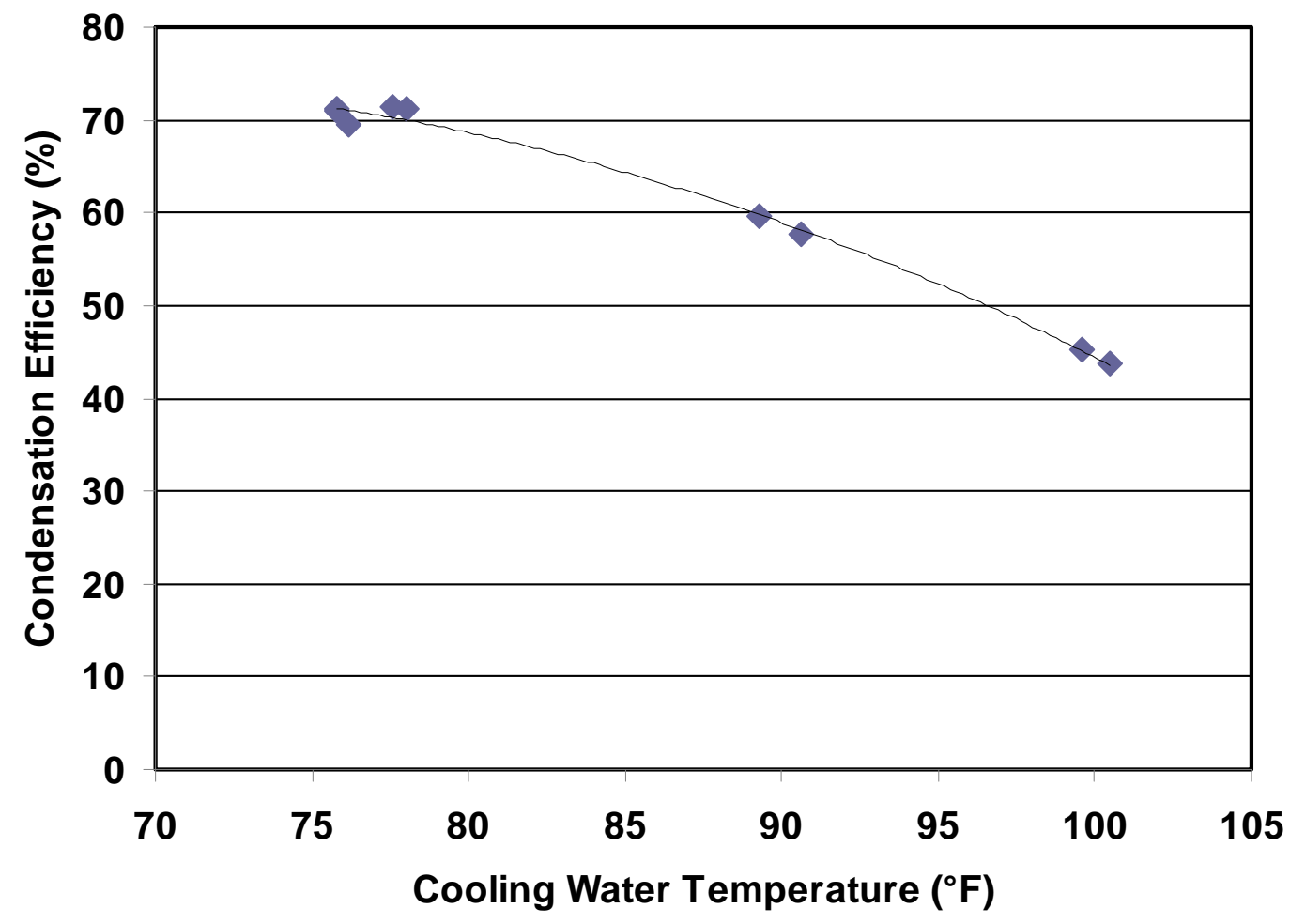

Figure 2-12: Water Vapor Capture Efficiency vs. Inlet Cooling Water Temperature: Unit A

Capture of Acids and Mercury. Samples of water which had condensed on the heat exchangers were analyzed to determine concentrations of sulfuric, hydrochloric and nitric acids. In addition, during some of the tests, the flue gas was sampled to obtain vapor phase concentrations of $\mathrm{H}_{2} \mathrm{SO}_{4}$ and mercury.

Boiler $C$ fires a bituminous coal and the slip stream of flue gas flowing through the heat exchanger system during the tests was extracted from the boiler immediately downstream of a wet FGD. Figure 2-13 shows sulfate concentrations in the condensate from the four heat exchangers used during those tests. The concentrations from HX1 and $\mathrm{HX} 2$ ranged from 600 to $1400 \mathrm{mg} / \mathrm{L}$, while the two downstream heat exchangers ( $\mathrm{HX} 3$ and HX4) had concentrations of less than $100 \mathrm{mg} / \mathrm{L}$.

Boiler B fires a PRB coal, and in this case, Controlled Condensation measurements of vapor phase $\mathrm{H}_{2} \mathrm{SO}_{4}$ concentrations showed an average value at the inlet to the slip stream heat exchanger system of $1.8 \mathrm{ppm}$. Five heat exchangers were used in the slip stream at Boiler B with condensate sulfate concentrations which ranged 
from 400 to $1800 \mathrm{mg} / \mathrm{L}$. The $\mathrm{H}_{2} \mathrm{SO}_{4}$ condensation flux on the tubes ranged from close to zero to approximately $70 \mathrm{mg} / \mathrm{ft}^{2} \mathrm{hr}$.

Figure 2-3 shows that both $\mathrm{HCl}$ and $\mathrm{HNO}_{3}$ condense at temperatures less than $140^{\circ} \mathrm{F}$. This is illustrated in Figures 2-14 and 2-15 from tests at Boiler A. Overall, the measured concentrations of $\mathrm{HCl}$ and $\mathrm{HNO}_{3}$ in the condensate were significantly lower than those of $\mathrm{H}_{2} \mathrm{SO}_{4}$, with the range of values of each summarized in Table 2-1.

Data on capture of flue gas mercury within the heat exchangers were obtained at Boilers $A$ and $B$. The mercury reduction ranged from 30 to 80 percent in unit $B$ to 60 percent in Unit $\mathrm{C}$, with the percentage capture increasing as the flue gas exit temperature decreased (Figures 2-16 and 2-17).

Table 2-1: Acid Concentrations (mg/L)

\begin{tabular}{|l|c|c|c|}
\hline & Unit A & Unit B & Unit C \\
\hline $\mathrm{H}_{2} \mathrm{SO}_{4}$ & 100 to 350 & 200 to 1800 & 50 to 1400 \\
\hline $\mathrm{HCl}$ & 10 to 100 & 5 to 55 & 0 to 15 \\
\hline $\mathrm{HNO}_{3}$ & 0.5 to 2 & 2 to 15 & 0 \\
\hline
\end{tabular}

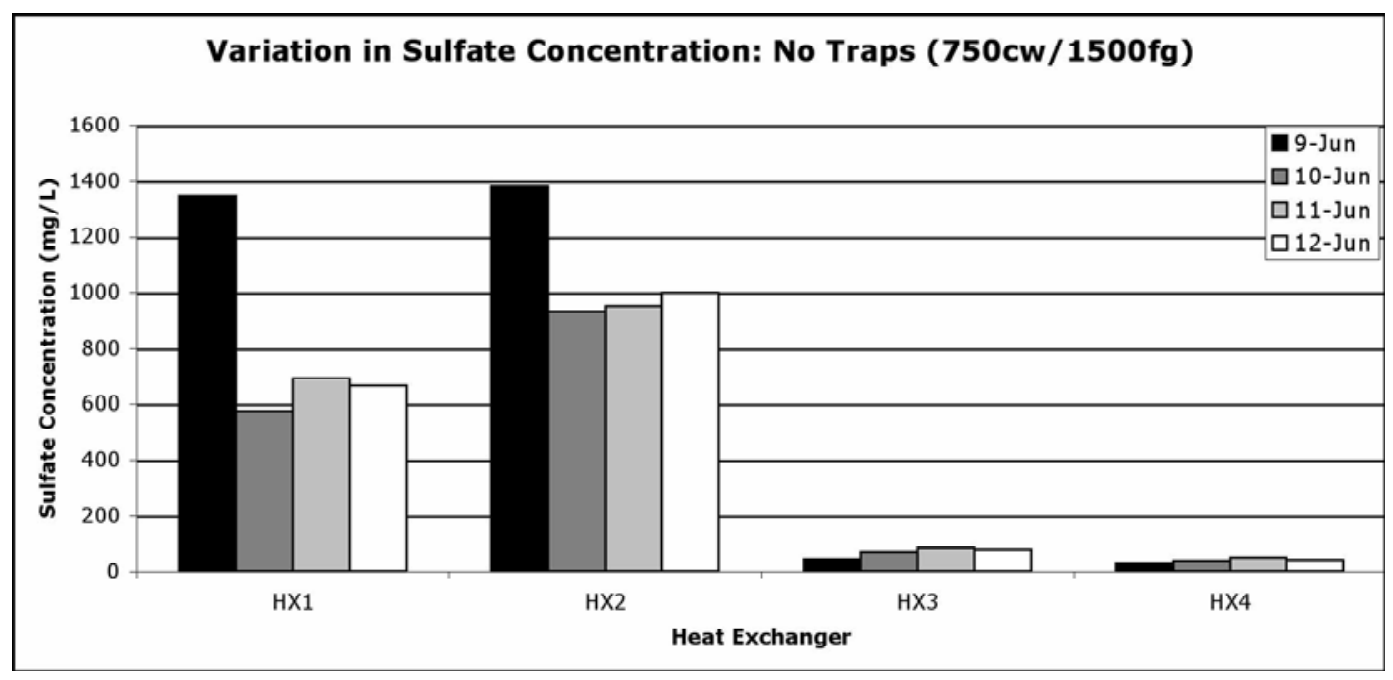

Figure 2-13: Condensate Sulfate Concentration from the Four Heat Exchangers. Flue Gas Entered at $\mathrm{HX1}$ and Exited at HX4: Boiler C. 


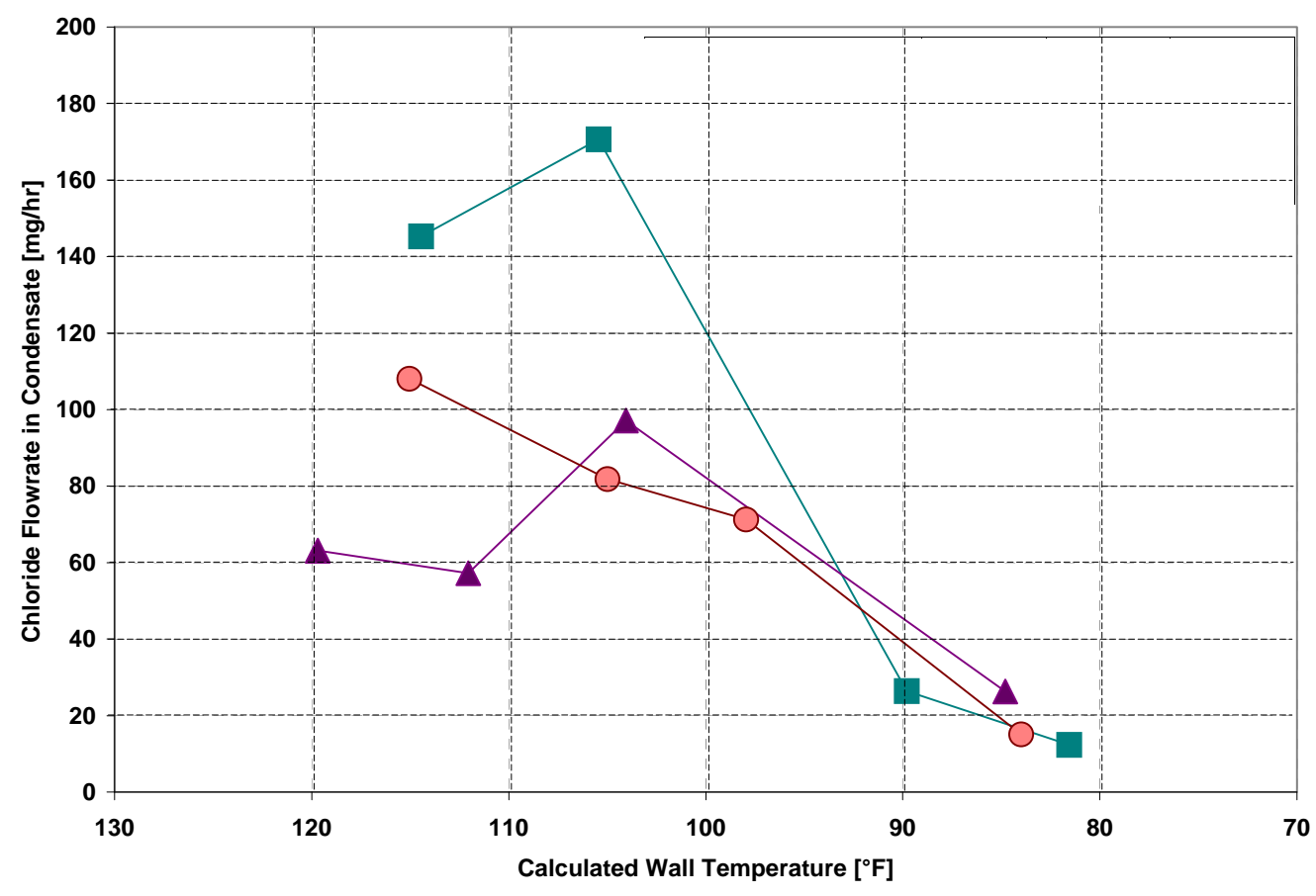

Figure 2-14: Chloride Flow Rates from Heat Exchangers HX3 to HX6 versus Tube Wall Temperature. Coal Test Data from Three Tests with $77^{\circ} \mathrm{F}$ Inlet Cooling Water Temperature. Boiler A.

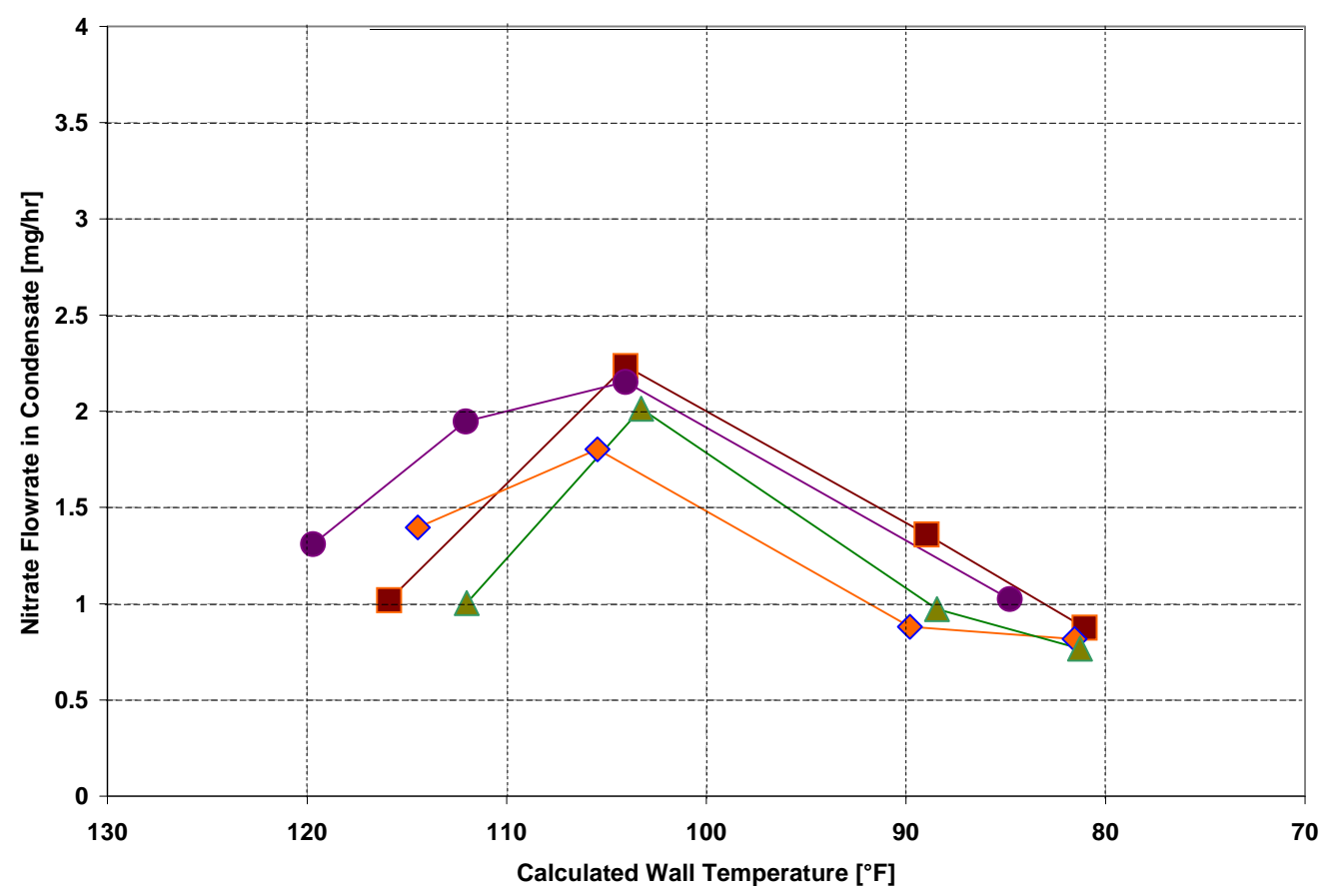

Figure 2-15: Nitrate Flow Rates from Heat Exchangers HX3 to HX6 versus Tube Wall Temperature. Coal Test Data from Four Tests with $77^{\circ} \mathrm{F}$ Inlet Cooling Water Temperature. Boiler A. 


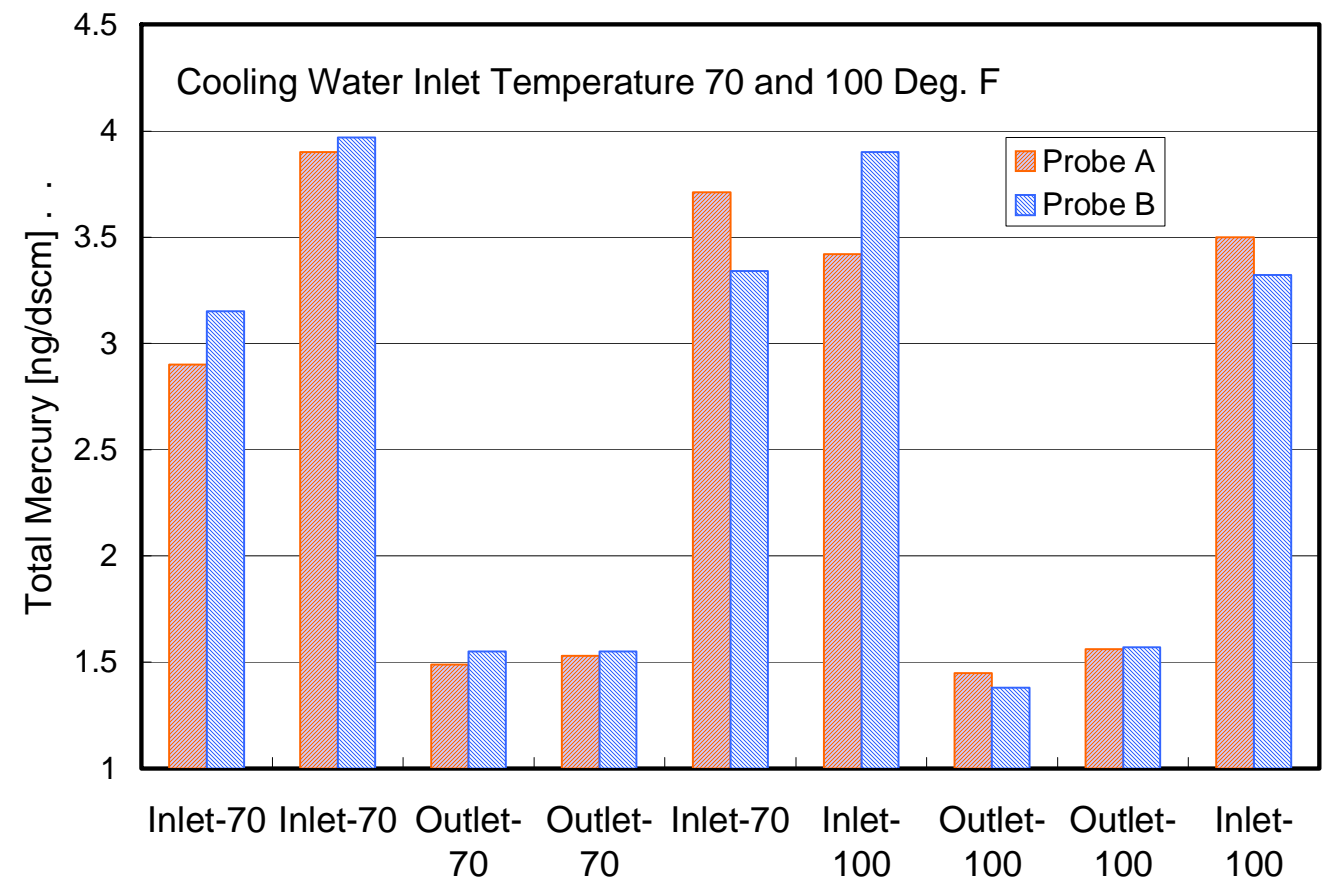

Figure 2-16: Inlet and Exit Values of Flue Gas Mercury at Unit A. Data Plotted in the Order in which the Tests Were Carried Out and the Measurements Made.

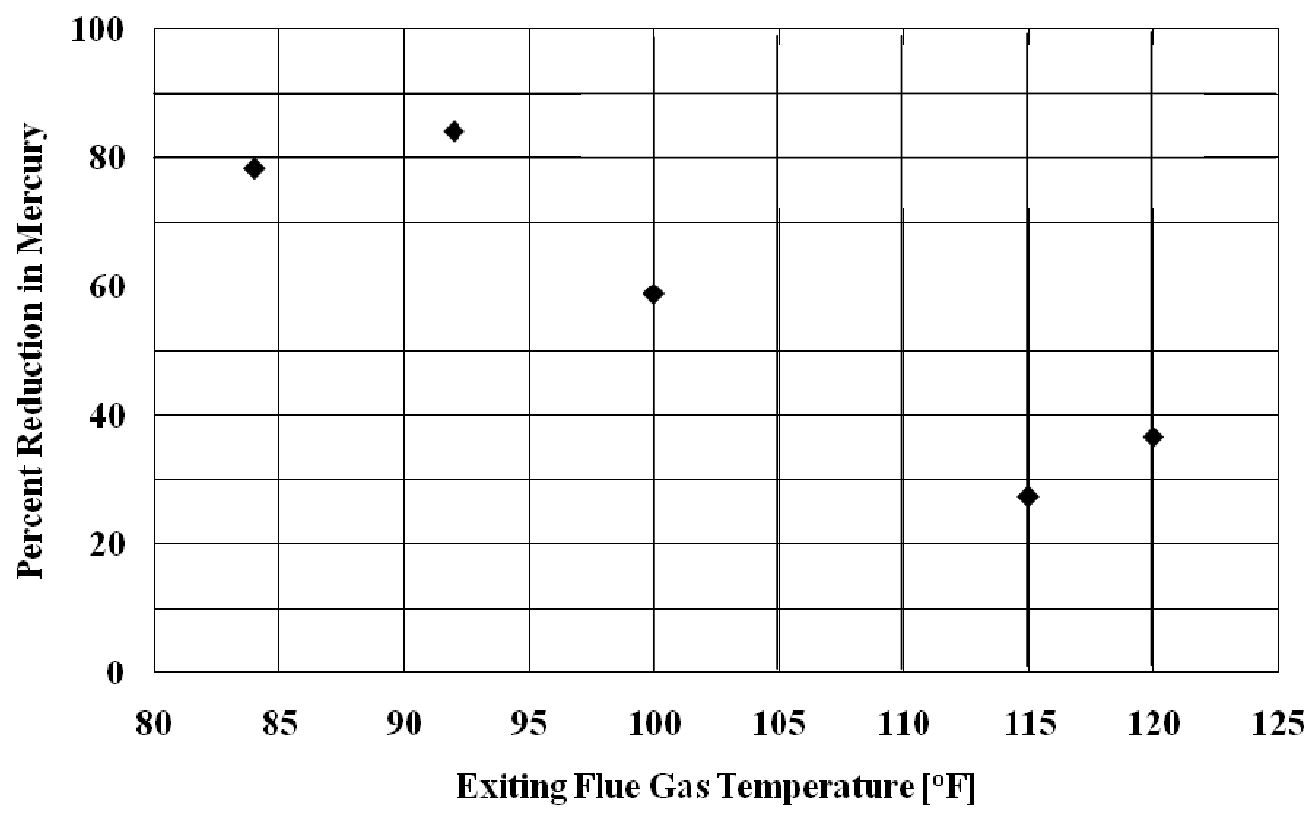

Figure 2-17: Percentage Reduction in Mercury Concentration as a Function of Flue Gas Exit Temperature: Unit B. 


\section{Summary and Conclusions}

Data on water capture efficiency and rate of heat transfer in water-cooled heat exchangers are presented for three coal-fired boilers, two of which utilized slip streams of flue gas taken from flue gas ducts downstream of the ESP's, while the flue gas slip stream from the third boiler was taken just downstream of a wet FGD. The inlet water vapor volume fractions were approximately the same, being 11 percent for one unit, 12 percent for the second and from 11 to 14 percent for the third unit. Cooling water inlet temperatures averaged $93^{\circ} \mathrm{F}$ for one unit, $85^{\circ} \mathrm{F}$ for the second unit and 75 to $100^{\circ} \mathrm{F}$ for the third unit. The results show a strong dependence of both total heat transfer and water vapor capture efficiency on the flow rate ratio of cooling water to flue gas. For flue gas from Unit $B$, the data show a 75 percent increase in rate of heat transfer as the cooling water to flue gas flow rate ratio increased from 0.5 to 1.6. The rate of water condensation capture efficiency also depended strongly on cooling water to flue gas flow rate ratio, increasing from approximately 20 percent at $\mathrm{mcw} / \mathrm{mfg}=0.5$ to 57 percent at $\mathrm{mcw} / \mathrm{mfg}=2.12$.

In the case of flue gas from Unit $\mathrm{C}$, the total rate of heat transfer increased by 105 percent and the condensation efficiency increased by 37 percent as the cooling water to flue gas flow rate ratio increased from 0.5 to 1.0.

Inlet cooling water temperature also has a strong impact on water vapor condensation efficiency. Results presented here for a cooling water to flue gas flow rate ratio of 2.0 show that condensation efficiency increased from 44 to 71 percent as inlet cooling water temperature decreased from 100 to $76^{\circ} \mathrm{F}$.

Sulfuric, hydrochloric and nitric acids were found in the condensed water which collected on the surfaces of the heat exchanger tubes. Among the three boilers, the concentrations of sulfuric acid ranged from 50 to $1800 \mathrm{mg} / \mathrm{L}$, hydrochloric acid was found in concentrations from 0 to $100 \mathrm{mg} / \mathrm{L}$, and the nitric acid concentrations ranged from 0 to $15 \mathrm{mg} / \mathrm{L}$. 
Mercury measurements were made during the tests at two of the units. The results showed that vapor phase mercury decreased by 60 percent between the inlet and exit of the heat exchanger system at Unit $A$ and from 30 to 80 percent at Unit $C$, with the percentage capture increasing as the flue gas exit temperature decreased.

The sulfuric acid concentrations reported here are for acid-water solutions which deposited on heat exchanger tubes at locations where the tube wall temperatures were lower than the local water vapor dew point temperatures. Sulfuric acid also condensed at tube wall temperatures between the water vapor and sulfuric acid dewpoint temperatures, however, the rates of liquid deposition were significantly lower at these temperatures and the tests were of too short a duration for the project team to be able to collect samples of the resulting acid-water solutions. Nevertheless, there are indications from the literature (Ref. 3) that these higher temperature solutions have much higher acid concentrations (and consequently cause higher corrosion rates) than the lower temperature aqueous solutions described in this Chapter.

If the heat exchangers are water cooled, the available cooling water flow rate and temperature will govern whether the heat exchangers are better suited for improving unit heat rate or recovering water vapor from flue gas for use as cooling tower makeup water. In the latter case, a likely source of cooling water will be cold boiler feedwater leaving the steam condenser. The flow rate of cold boiler feedwater is typically about one half of the flue gas flow rate of the unit and depending on time of year and whether the unit uses once-through cooling or an evaporative cooling tower, the feedwater temperature typically ranges from 85 to $110^{\circ} \mathrm{F}$. Recovery of water vapor from flue gas can be enhanced through a combination of water and air-cooled heat exchangers (Ref. 4).

For applications in which heat rate improvement is the principal concern, in order to maximize the total rate of heat transfer rate, the flue gas heat exchangers will need to be cooled with cooling water-to-flue gas flow ratios which are larger than 0.5 and cooling water inlet temperatures which are lower than typical cold boiler feedwater temperatures. 


\section{References}

1. Verhoff, F.H. and J.T. Banchero, "Predicting Dew Points of Flue Gas," Chemical Engineering Progress, Vol. 70, No. 8, pp 71-72, 1974.

2. Yen Hsiung Kiang, "Predicting Dew Points of Acid Gases," Chemical Engineering, February 9, 1981, p. 127.

3 Abel, E., "The Vapor Phase Above the System Sulfuric Acid-Water," Journal of Physical Chemistry, Vol. 50, No. 3, pp. 260-283, 1946.

4. Levy, E. K., C. Whitcombe, I. Laurenzi, and H. Bilirgen, "Potential Water Vapor Recovery Rates and Heat Rate Reductions Resulting from Condensation of Water Vapor in Boiler Flue Gas," Proceedings $34^{\text {th }}$ International Technical Conference on Clean Coal \& Fuel Systems, Clearwater, Florida, May 31 to June 4, 2009. 


\section{CHAPTER 3}

\section{CONCENTRATIONS OF DEPOSITS OF SULFURIC ACID AND WATER ON HEAT EXCHANGER TUBES}

\section{Introduction}

As boiler flue gas is reduced in temperature below the sulfuric acid dew point, the acid first condenses as a highly concentrated solution of sulfuric acid and water. Flue gas from coal-fired boilers also contains relatively high water vapor concentrations, resulting in water vapor dewpoint temperatures from 100 to $135^{\circ} \mathrm{F}\left(37.7^{\circ} \mathrm{C}\right.$ to $\left.57.2^{\circ} \mathrm{C}\right)$, depending on coal moisture content. For those applications in which the flue gas temperature is reduced to temperatures below the water vapor dewpoint, the liquid mixture of water and sulfuric acid which forms is approximately two orders of magnitude more dilute in sulfuric acid than the highly concentrated acid solutions which form at temperatures above the water vapor dewpoint temperature, but below the sulfuric acid dew point temperature.

At the beginning of the project, it was thought to be very likely that the tube materials which will be most cost effective in the high temperature region with high acid concentrations will be different from the materials of choice in the lower temperature region with dilute acid mixtures. Long-term laboratory corrosion tests, designed to simulate the corrosive condensate solutions encountered in field tests carried out in the project, were conducted to identify materials which will provide adequate service life along with desired heat transfer and structural properties. Chemical analysis of acid concentrations in condensed water collected during heat exchanger slip stream field tests provided data on the concentrations of the dilute water-acid mixtures which form at temperatures below the water vapor dew point. Information on the concentrations of high temperature concentrated sulfuric acid-water mixtures was developed from published literature on the thermodynamics of phase equilibrium of sulfuric acid-water mixtures. 


\section{Concentrations of Sulfuric Acid-Water Mixtures at Temperatures above the Water Vapor Dew Point Temperature}

For this analysis, the flue gas is modeled as a two phase mixture of sulfuric acid, water, and inert gases. The presence of the inert gases can be ignored in analyses of equilibrium acid concentrations. The thermodynamics of the sulfuric acid-water system was described by Abel (Ref. 1), and the description of the phase equilibrium model given below is based on Abel's work.

The variables are:

$\mathrm{T}=$ Temperature

$\pi=$ mass fraction of $\mathrm{H}_{2} \mathrm{SO}_{4}$ in liquid

$\mathrm{p}_{\mathrm{w}}=$ partial pressure of water vapor in flue gas

$\mathrm{p}_{\pi}=$ partial pressure of $\mathrm{H}_{2} \mathrm{SO}_{4}$ in flue gas

Total pressure $=p_{\mathrm{w}}+p_{\pi}$

The molar composition of the flue gas is expressed in terms of the mole fraction or partial pressure of water vapor in the gas phase and the partial pressure or concentration of $\mathrm{H}_{2} \mathrm{SO}_{4}$ vapor in ppm's. The correlation by Banchero and Verhoff (Ref. 2) was used in this study to express acid dew point temperature (T) as a function of $p_{w}$ and $\mathrm{p}_{\pi}$ (Equation 1). In the Banchero and Verhoff correlation, $\mathrm{T}$ is in degrees Kelvin and $\mathrm{p}_{\mathrm{w}}$ and $\mathrm{p}_{\pi}$ are in $\mathrm{mm} \mathrm{Hg}$.

$$
\frac{1}{\mathrm{~T}}=0.002276-0.00002943 \ell \mathrm{n}_{\mathrm{w}}-0.0000858 \ell \mathrm{n}_{\pi}+0.00000620\left(\ell \mathrm{np}_{\mathrm{w}} \times \ell n \mathrm{p}_{\pi}\right)
$$

Abel gives a relation between the mass percent, $\pi$, of sulfuric acid in the liquid phase, the partial pressure of sulfuric acid in the vapor phase, $\mathrm{p}_{\pi}$, in $\mathrm{mm} \mathrm{Hg}$ and acid dew point temperature, $\mathrm{T}$ in degrees Kelvin (Table 3-1 and Equation 2).

$$
\log p_{\pi}=A_{\pi}+\frac{B_{\pi}}{T}+D_{\pi} \log T+E_{\pi} T
$$


Table 3-1: Coefficients for Abel's Equation for the Vapor Pressure of Sulfuric Acid as a Function of Mass Fraction of $\mathrm{H}_{2} \mathrm{SO}_{4}$ in Liquid Phase $(\pi)$ and Acid Dew Point Temperature

\begin{tabular}{|c|c|c|c|c|}
\hline$\Pi$ & $A_{\pi}$ & $\left(-B_{\pi} \pm 50\right) \times 10^{-3}$ & $D_{\pi}$ & $E_{\pi} \times 10^{3}$ \\
\hline 5 & +21.2 & 7.55 & -5.58 & +6.7 \\
\hline 10 & +45.4 & 8.30 & -14.60 & +10.5 \\
\hline 15 & +59.5 & 8.64 & -19.90 & +13.3 \\
\hline 20 & +66.4 & 8.66 & -22.70 & +15.9 \\
\hline 25 & +40.1 & 7.85 & -12.00 & +7.7 \\
\hline 30 & +23.5 & 7.06 & -5.88 & +5.6 \\
\hline 35 & 11.3 & 6.50 & -1.10 & +2.5 \\
\hline 40 & -3.8 & 5.84 & +4.73 & -0.6 \\
\hline 45 & -4.1 & 5.66 & +5.03 & -1.8 \\
\hline 50 & -4.7 & 5.56 & +5.62 & -4.2 \\
\hline 55 & 3.1 & 5.59 & +2.71 & -3.0 \\
\hline 60 & 7.0 & 5.60 & +1.76 & -4.5 \\
\hline 65 & -5 & 5.00 & +6.38 & -7.7 \\
\hline 70 & -4.8 & 4.86 & +6.73 & -9.9 \\
\hline 75 & +29.2 & 5.62 & -6.73 & -1.2 \\
\hline 80 & +47.1 & 5.98 & -13.60 & +2.4 \\
\hline 85 & +45.7 & 5.54 & -13.65 & +5.0 \\
\hline 90 & +4.8 & 4.19 & +2.46 & -4.8 \\
\hline 95 & +14.6 & 4.44 & -1.25 & -2.8 \\
\hline 98.3 & +16.3 & 4.48 & -1.75 & -2.6 \\
\hline
\end{tabular}

Values for the $\mathrm{H}_{2} \mathrm{SO}_{4}$ vapor pressure in ppm, for liquid mass fractions in the 65 to 90 percent range and temperatures from 50 to $150^{\circ} \mathrm{C}$ range are shown in Figure 3-1. This figure can be used to estimate the liquid composition and temperature for different gas compositions. 


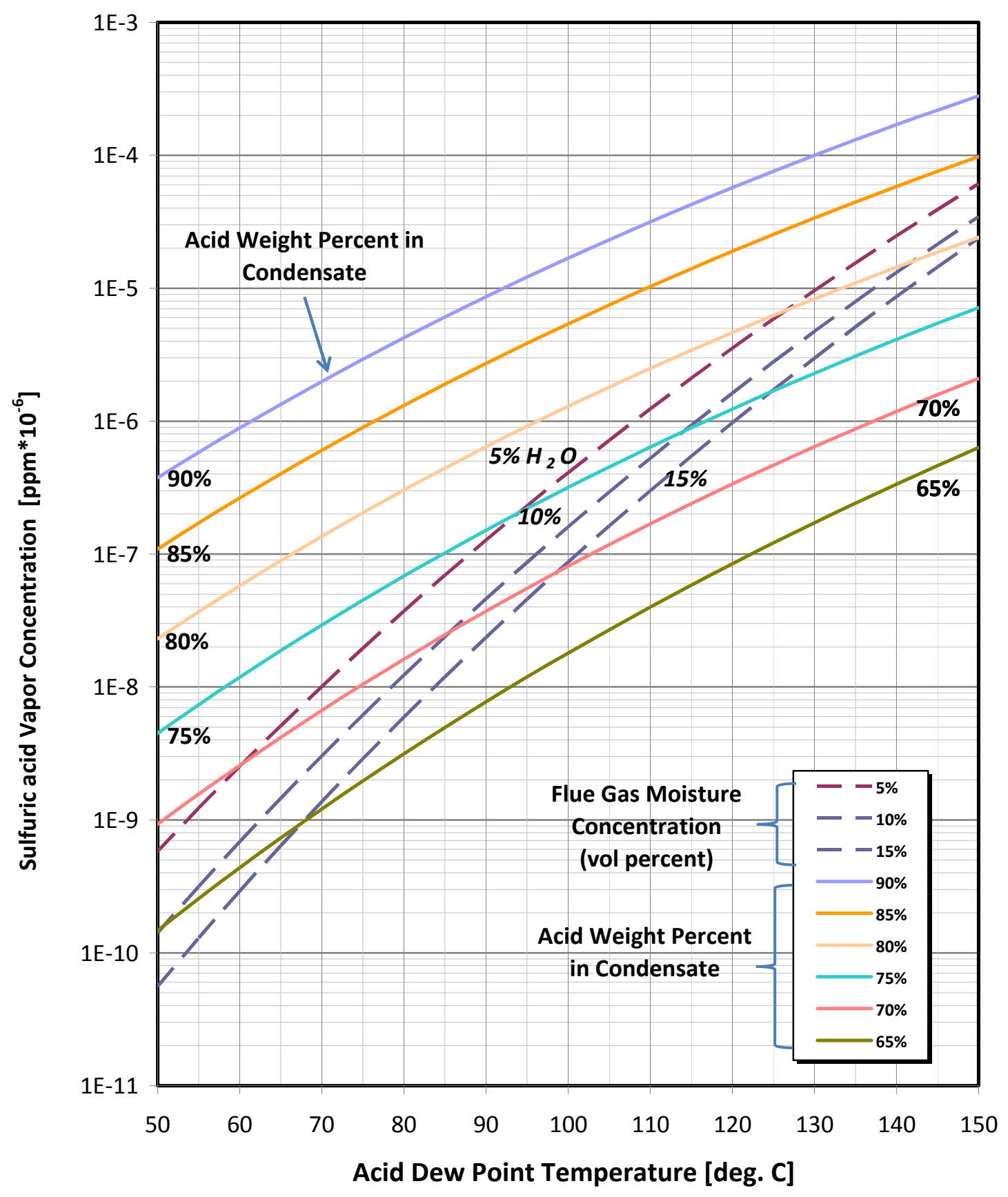

Figure 3-1: This graph can be used to determine the acid weight percent in the liquid phase as a function of flue gas water vapor volume concentration and acid dew point temperature, or equivalently, the tube wall temperature. 


\section{Acid Concentrations at Temperatures Below the Water Vapor Dew Point Temperature}

Samples of water which had condensed on the heat exchangers in slipstream tests at three coal-fired boilers were analyzed to determine concentrations of sulfuric, hydrochloric and nitric acids at temperatures below the water vapor dew point temperature.

Boiler $\mathrm{C}$ fires a bituminous coal and the slip stream of flue gas flowing through the heat exchanger system during the tests was extracted from the boiler immediately downstream of a wet FGD. Four heat exchangers were used during those tests and the sulfuric acid concentrations from HX1 and HX2 ranged from 600 to $1400 \mathrm{mg} / \mathrm{L}$, while the two downstream heat exchangers ( $\mathrm{HX} 3$ and $\mathrm{HX} 4)$ had sulfuric acid concentrations of less than $100 \mathrm{mg} / \mathrm{L}$.

Boiler B fires a PRB coal, and in this case, Controlled Condensation measurements of vapor phase $\mathrm{H}_{2} \mathrm{SO}_{4}$ concentrations showed an average value at the inlet to the slip stream heat exchanger system of $1.8 \mathrm{ppm}$. Five heat exchangers were used in the slip stream at Boiler B with condensate sulfate concentrations which ranged from 400 to $1800 \mathrm{mg} / \mathrm{L}$.

Both $\mathrm{HCl}$ and $\mathrm{HNO}_{3}$ condensed at temperatures less than $140^{\circ} \mathrm{F}$. Overall, the measured concentrations of $\mathrm{HCl}$ and $\mathrm{HNO}_{3}$ in the condensate were significantly lower than those of $\mathrm{H}_{2} \mathrm{SO}_{4}$, with the range of values of each summarized in Table 3-2.

Table 3-2: Acid Concentrations (mg/L)

\begin{tabular}{|l|c|c|c|}
\hline & Unit A & Unit B & Unit C \\
\hline $\mathrm{H}_{2} \mathrm{SO}_{4}$ & 100 to 350 & 200 to 1800 & 50 to 1400 \\
\hline $\mathrm{HCl}$ & 10 to 100 & 5 to 55 & 0 to 15 \\
\hline $\mathrm{HNO}_{3}$ & 0.5 to 2 & 2 to 15 & 0 \\
\hline
\end{tabular}




\section{References}

1. Abel, E, "The Vapor Phase Above the System Sulfuric Acid-Water." Journal of Physical Chemistry, Vol. 50, No. 3, pp. 260-283, 1946.

2. Banchero, J. T. and F. Verhoff, "Evaluation and Interpretation of the Vapour Pressure Data for Sulfuric Acid Aqueous Solutions with Application to Flue Gas Dew Points." J. Institute of Fuel, pp. 76 - 86, June 1975. 


\section{CHAPTER 4}

\section{LABORATORY CORROSION TESTS OF CANDIDATE HEAT EXCHANGER TUBE MATERIALS}

\section{Introduction}

From slip stream tests carried out using boiler flue gas and from theoretical analyses performed by the project team, it became apparent that as flue gas is reduced in temperature below the sulfuric acid dew point, the acid first condenses as a highly concentrated liquid solution of sulfuric acid and water. Flue gas from coal-fired boilers contains relatively high water vapor concentrations, resulting in water vapor dewpoint temperatures from 100 to $135^{\circ} \mathrm{F}$, depending on coal moisture content. For those applications in which the flue gas temperature is reduced to temperatures below the water vapor dewpoint, the liquid mixture of water and sulfuric acid which forms on low temperature surfaces is approximately two orders of magnitude more dilute in sulfuric acid than the highly concentrated acid solutions which form at temperatures above the water vapor dewpoint temperature, but below the sulfuric acid dew point temperature (see Chapter 3).

Depending on factors such as coal composition and combustion conditions, dilute sulfuric acid-water liquid mixtures can also contain hydrochloric and nitric acids. The objective of this part of the project was to determine the best materials to use for heat exchangers in each of these two distinct acid environments: (1) higher temperature, with highly concentrated sulfuric acid and (2) lower temperature with a dilute acid mixture, possibly containing sulfuric, hydrochloric and nitric acids.

Long-term laboratory corrosion tests, which were designed to simulate the corrosive condensate solutions which were observed in field tests performed by the project team, were conducted to identify materials which would provide adequate service life along with desired heat transfer and structural properties. Chemical analysis of acid concentrations in condensed water collected during heat exchanger slip stream field tests provided data on the concentrations of the dilute water-acid mixtures which 
form. Information on the concentrations of high temperature concentrated sulfuric acidwater mixtures was developed by the project team from published literature on the thermodynamics of concentrated liquid sulfuric acid.

\section{Experimental Procedure}

Long-term corrosion tests were conducted to identify materials that will provide adequate service life in various locations of the heat exchanger. Table 4-1 lists the nine different test conditions. The first condition was included as a screening test (prior to receipt of all samples and completion of condensate composition and temperature calculations) in order to make an initial assessment of the expected corrosion behavior. The next five conditions (2 through 6 ) represent condensate compositions and temperatures expected from the high temperature region of the heat exchanger, while the remaining conditions ( 7 through 9 ) represent those expected from the low temperature region of the heat exchanger.

Table 4-1: Summary of Condensate Compositions and Temperatures.

\begin{tabular}{|c|c|c|}
\hline Condition & Condensate Composition & $\begin{array}{c}\text { Condensate } \\
\text { Temperature, }{ }^{\circ} \mathrm{C}\end{array}$ \\
\hline 1 & $60 \% \mathrm{H}_{2} \mathrm{SO}_{4}-40 \% \mathrm{H}_{2} \mathrm{O}$ & 121 \\
\hline 2 & $65 \% \mathrm{H}_{2} \mathrm{SO}_{4}-35 \% \mathrm{H}_{2} \mathrm{O}$ & 50 \\
\hline 3 & $67 \% \mathrm{H}_{2} \mathrm{SO}_{4}-33 \% \mathrm{H}_{2} \mathrm{O}$ & 67.5 \\
\hline 4 & $70 \% \mathrm{H}_{2} \mathrm{SO}_{4}-30 \% \mathrm{H}_{2} \mathrm{O}$ & 85 \\
\hline 5 & $74 \% \mathrm{H}_{2} \mathrm{SO}_{4}-26 \% \mathrm{H}_{2} \mathrm{O}$ & 115 \\
\hline 6 & $80 \% \mathrm{H}_{2} \mathrm{SO}_{4}-20 \% \mathrm{H}_{2} \mathrm{O}$ & 150 \\
\hline 7 & 50 mg/L $\mathrm{H}_{2} \mathrm{SO}_{4}-10 \mathrm{mg} / \mathrm{L} \mathrm{HCl}-0.5 \mathrm{mg} / \mathrm{L} \mathrm{HNO}_{3}$-Bal. $\mathrm{H}_{2} \mathrm{O}$ & 21 \\
\hline 8 & $375 \mathrm{mg} / \mathrm{L} \mathrm{H}_{2} \mathrm{SO}_{4}-110 \mathrm{mg} / \mathrm{L} \mathrm{HCl}-2.3 \mathrm{mg} / \mathrm{L} \mathrm{HNO}_{3}$-Bal. $\mathrm{H}_{2} \mathrm{O}$ & 54 \\
\hline 9 & $2000 \mathrm{mg} / \mathrm{L} \mathrm{H}_{2} \mathrm{SO}_{4}-110 \mathrm{mg} / \mathrm{L} \mathrm{HCl}-\mathrm{Bal} . \mathrm{H}_{2} \mathrm{O}$ & 65.5 \\
\hline
\end{tabular}

A wide range of carbon and low alloy steels, stainless steels, nickel base alloys, polymers, aluminum, an aluminum bronze alloy, graphite, and Teflon coatings were included in the test program. The compositions of the engineering alloys are provided in Table A in the Appendix. The two Teflon coatings (MP501 and Ruby Red, made by DuPont ${ }^{\mathrm{TM}}$ ) were applied to 1018 steel substrates. A 1018 steel rod with a 1/8 inch diameter was tack-welded onto the top of the substrates prior to coating in order to handle the samples during coating application. The coatings were applied by Plas-Tech (West Chester, PA), which is DuPont-approved applicator for these coatings. Table 4-2 
summarizes the materials tested in each condition. The nickel alloys 22 and 625 and aluminum bronze alloy were also tested in the welded condition since welds in these alloys are known to exhibit microsegregation of alloying elements that can potentially adversely affect corrosion resistance [Ref. 1]. Preliminary corrosion results conducted in the 60 percent $\mathrm{H}_{2} \mathrm{SO}_{4}$ solution at $121^{\circ} \mathrm{C}$ demonstrated that the stainless steels, Alloy 600 , and the aluminum alloys were not suitable for the higher acid concentration conditions. These alloys all had corrosion rates above $\sim 8 \mathrm{~mm} / \mathrm{year}$. Thus, they were not considered further for the high acid conditions. The remaining materials were then tested first in conditions 2, 4, and 6. Materials not suitable for these conditions were not tested in conditions 3 and 5 . Similarly, all materials were tested in condition 9 first, and only materials suitable in this condition were evaluated in conditions 7 and 8 . Welded samples were not considered for the low acid conditions because no significant adverse effect was observed for the high acid conditions.

As shown in Figure 4-1, the materials were placed in test tubes that were filled with the simulated solution and positioned within a constant temperature bath. Silicon heating oil was used for the $115^{\circ} \mathrm{C}$ and $150^{\circ} \mathrm{C}$ tests, while peanut oil was used for the remaining tests. Test temperatures were held to $\pm 1^{\circ} \mathrm{C}$ of the set value. A condenser was placed on top of each test tube in order to re-condense any acid that evaporated during the test. The test samples were completely immersed in the solution, and up to 25 individual tests were conducted in each constant temperature bath.

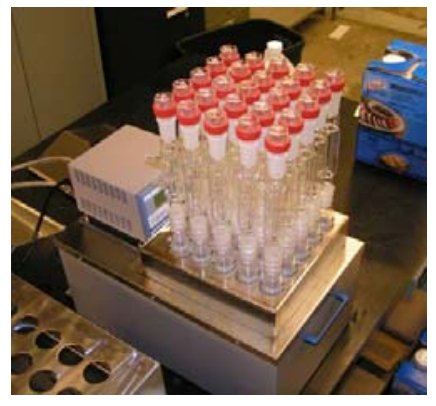

a)

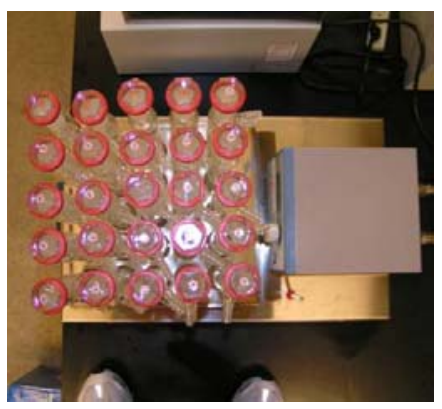

b)

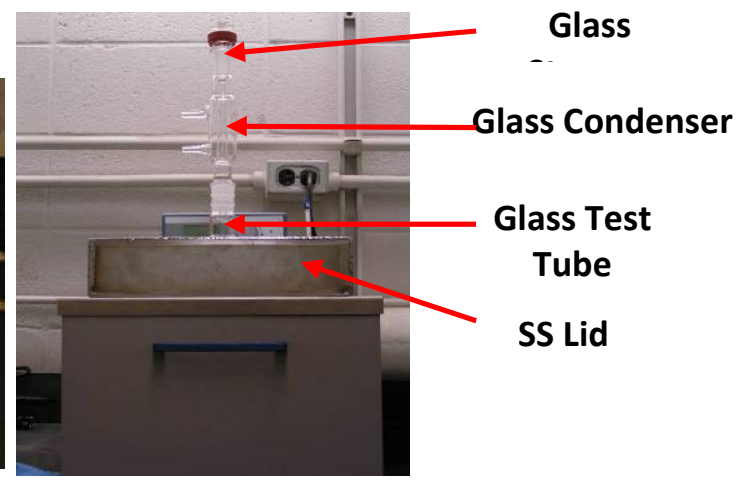

c)

Figure 4-1: Setup of the Long-Term Corrosion Testing. A) Side View of the Bath B) Overhead View of the Bath C) Side View of the Test Tube Showing the Individual Components of the Test Tube Setup. 
Table 4-2: Summary of Alloys Tested Under Various Conditions.

\begin{tabular}{|c|c|c|c|c|c|c|c|c|c|}
\hline \multirow{2}{*}{$\begin{array}{c}\text { Condition } \rightarrow \\
\text { Alloy } \downarrow\end{array}$} & \multicolumn{6}{|c|}{ High Acid Conditions } & \multicolumn{3}{|c|}{$\begin{array}{l}\text { Low Acid } \\
\text { Conditions }\end{array}$} \\
\hline & 1 & 2 & 3 & 4 & 5 & 6 & 7 & 8 & 9 \\
\hline \multicolumn{10}{|l|}{ STEELS: } \\
\hline 1018 & $\mathrm{X}$ & $\mathrm{x}$ & & $\mathrm{X}$ & & $\mathrm{X}$ & $\mathrm{X}$ & $\mathrm{X}$ & $\mathrm{X}$ \\
\hline A387 & $\mathrm{x}$ & $\mathrm{x}$ & & $\mathrm{X}$ & & $\mathrm{X}$ & $\mathrm{x}$ & $x$ & $\mathrm{x}$ \\
\hline Corten B & $\mathrm{x}$ & $\mathrm{x}$ & & $\mathrm{X}$ & & $\mathrm{X}$ & $\mathrm{X}$ & $\mathrm{X}$ & $\mathrm{X}$ \\
\hline \multicolumn{10}{|c|}{ STAINLESS STEELS: } \\
\hline 304 & $\mathrm{x}$ & & & & & & $x$ & $X$ & $\bar{x}$ \\
\hline 316 & $\mathrm{X}$ & & & & & & $X$ & $X$ & $\bar{X}$ \\
\hline AL6XN & $\mathrm{X}$ & & & & & & $\mathrm{X}$ & $\mathrm{X}$ & $\mathrm{x}$ \\
\hline 2205 & & & & & & & $\mathrm{X}$ & $\mathrm{X}$ & $\mathrm{x}$ \\
\hline \multicolumn{10}{|l|}{ Ni ALLOYS: } \\
\hline 22 & $\mathrm{X}$ & $\mathrm{x}$ & $\mathrm{X}$ & $\mathrm{X}$ & $\mathrm{X}$ & $\mathrm{X}$ & $\mathrm{X}$ & $\mathrm{X}$ & $\mathrm{X}$ \\
\hline 22-Welded & & $\bar{X}$ & & $\mathrm{X}$ & & $\mathrm{X}$ & & & \\
\hline 59 & & $\mathrm{x}$ & $\mathrm{X}$ & $\mathrm{X}$ & $\mathrm{X}$ & $\mathrm{X}$ & & & $\mathrm{X}$ \\
\hline 600 & $\mathrm{X}$ & & & & & & $\mathrm{X}$ & $X$ & $\mathrm{x}$ \\
\hline 625 & & $\bar{x}$ & $\mathrm{X}$ & $\mathrm{X}$ & $\mathrm{X}$ & $\mathrm{X}$ & & & $\mathrm{X}$ \\
\hline 625-Welded & & $\mathrm{x}$ & & $X$ & & $\mathrm{X}$ & & & \\
\hline 690 & & $\mathrm{x}$ & X & $\mathrm{X}$ & X & $\mathrm{X}$ & & & $\mathrm{X}$ \\
\hline \multicolumn{10}{|l|}{ ALUMINUM BRONZE: } \\
\hline C-61400 & $\mathrm{x}$ & $\mathrm{x}$ & $\mathrm{X}$ & $\mathrm{X}$ & & $\mathrm{X}$ & $X$ & $\mathrm{X}$ & $\mathrm{X}$ \\
\hline C-61400-Welded & & $\mathrm{x}$ & & $\mathrm{X}$ & & $\mathrm{X}$ & & & \\
\hline \multicolumn{10}{|l|}{ ALUMINUM: } \\
\hline 3003 & & & & & & & $\mathrm{X}$ & $\mathrm{X}$ & $\bar{X}$ \\
\hline 6061 & & & & & & & $\mathrm{X}$ & $\mathrm{X}$ & $\mathrm{X}$ \\
\hline \multicolumn{10}{|l|}{ POLYMERS: } \\
\hline FEP & $\mathrm{X}$ & $\mathrm{X}$ & & $\mathrm{X}$ & $\mathrm{X}$ & $\mathrm{X}$ & $\mathrm{X}$ & $\mathrm{X}$ & $\bar{X}$ \\
\hline PTFE & $\mathrm{x}$ & $\mathrm{x}$ & & $\mathrm{X}$ & $\mathrm{X}$ & $\mathrm{X}$ & $\mathrm{X}$ & $\mathrm{X}$ & $\mathrm{x}$ \\
\hline PEEK & & $\mathrm{x}$ & & $X$ & $\mathrm{X}$ & $\mathrm{X}$ & & & $\mathrm{X}$ \\
\hline \multicolumn{10}{|l|}{ TEFLON COATINGS: } \\
\hline MP501 & & $\mathrm{X}$ & & $\mathrm{X}$ & & $\mathrm{X}$ & & $X$ & $\mathrm{X}$ \\
\hline Ruby Red & & $\mathrm{X}$ & & $x$ & & $x$ & & $\mathrm{X}$ & $\mathrm{X}$ \\
\hline GRAPHITE & & $\mathrm{x}$ & & $\mathrm{X}$ & $\mathrm{X}$ & $\mathrm{X}$ & & & $\mathrm{X}$ \\
\hline
\end{tabular}

The samples of each material were machined to dimensions of $1 / 4 " \times 3 / 4 \times 1 \frac{1}{2}$ " and then ground to an 80 grit finish prior to being placed in the test solution. The graphite was received in tube form that had a one inch outside diameter and 0.60 inch inside diameter. Graphite test samples were one inch in length. All test samples were weighed prior to testing and during periodic examination intervals (typically every 14 days). Fresh acid solution was provided after each inspection. The equivalent thickness loss associated with each measured mass loss was determined by dividing the mass loss by the density and surface area of each sample. The corrosion rate was then determined by dividing the effective thickness loss by the exposure time. This assumes uniform corrosion, which was justified by subsequent inspections of the 
samples (as discussed in the next section). Various samples were photographed after the tests. Select samples were used for examination by light optical microscopy (LOM). The LOM samples were mounted in bakelite and filled with epoxy. They were then cross sectioned and metallographically prepared to a one micron surface finish using a diamond slurry as the final polishing step. Samples were examined and photographed in the as-polished condition.

\section{Results and Discussion}

Individual plots of the thickness loss as a function of time are provided in Appendix A for each test condition. Conditions 2 through 6 and condition 8 were tested twice in order to assess the reproducibility of the results. A few of the materials exhibited an initial transient period with a relatively low or high thickness loss rate followed by a linear change in thickness loss with time. Examples of this type of behavior can be seen with alloy 690 tested in the 65 percent $\mathrm{H}_{2} \mathrm{SO}_{4}$ solution at $65^{\circ} \mathrm{C}$ (Figures A2-a and A2-b) and alloy 625 tested in the 74 percent $\mathrm{H}_{2} \mathrm{SO}_{4}$ solution at $115^{\circ} \mathrm{C}$ (Figures A5-a and A5-b). However, most of the materials exhibited a linear change in

thickness loss with time over the entire test period. This trend, together with the observed uniform corrosion loss on the samples (discussed below), justifies determination of a general corrosion rate. The corrosion rate for each material was determined from the slope of the plots by conducting linear regression analysis through the data. This was accomplished by fitting a first order polynomial equation through the data. Initial transients were not included in the data fitting so that the reported values acquired from the slopes represent the steady state corrosion rate. The corrosion rates for condition 1 are summarized in Table 4-3 while results for the high acid and low acid conditions are provided in Tables 4-4 and 4-5, respectively. Meaningful corrosion rates cannot be obtained for the coated samples because it is not possible to distinguish between the different contributions to weight changes using the current testing techniques. For example, weight gain could be caused by solution permeation into the coating followed by corrosion of the underlying steel substrate, while weight loss could be an indication of the coating leaching into the solution. Thus, the raw weight change data for these samples are presented in Figures A10-a and A10-b. 
Table 4-3: Summary of Corrosion Rates Measured Under Condition 1. All Values in $\mathrm{mm} / \mathrm{year}$.

\begin{tabular}{|l|c|}
\hline \multicolumn{1}{|c|}{ Alloy } & $\begin{array}{c}\text { Corrosion Rate } \\
\text { mm/year }\end{array}$ \\
\hline STEELS: & 1.24 \\
\hline 1018 & 0.91 \\
\hline A387 & 1.10 \\
\hline Corten B & 28.8 \\
\hline STAINLESS STEELS: & 28.8 \\
\hline 304 & 8.36 \\
\hline 316 & $(1)$ \\
\hline AL6XN & \\
\hline 2205 & 3.65 \\
\hline Ni ALLOYS: & 14.6 \\
\hline 22 & \\
\hline 600 & 2.74 \\
\hline ALUMINUM BRONZE: & \\
\hline C-61400 & $(1)$ \\
\hline ALUMINUM: & $(1)$ \\
\hline 3003 & \\
\hline 6061 & 0.002 \\
\hline POLYMERS: & 0.002 \\
\hline FEP & \\
\hline PTFE & \\
\hline
\end{tabular}

Note 1 - These materials disintegrated shortly after exposure at this test condition.

Table 4-4: Summary of Corrosion Rates Measured Under High Acid Condensate Solutions. All Values in $\mathrm{mm} /$ year.

\begin{tabular}{|l|c|c|c|c|c|c|c|c|c|}
\hline \multicolumn{1}{|c|}{ Alloy } & $\begin{array}{c}\mathbf{2 A} \\
\mathbf{1}^{\text {st }} \\
\text { Test }\end{array}$ & $\begin{array}{c}\mathbf{2 B} \\
\mathbf{2}^{\text {nd }} \\
\text { Test }\end{array}$ & $\begin{array}{c}\mathbf{3 A} \\
\mathbf{1}^{\text {st }} \\
\text { Test }\end{array}$ & $\begin{array}{c}\mathbf{3 B} \\
\mathbf{2}^{\text {nd }} \\
\text { Test }\end{array}$ & $\begin{array}{c}\mathbf{4 A} \\
\mathbf{1}^{\text {st }} \\
\text { Test }\end{array}$ & $\begin{array}{c}\mathbf{4 B} \\
\mathbf{2}^{\text {nd }} \\
\text { Test }\end{array}$ & $\begin{array}{c}\mathbf{5 A} \\
\mathbf{1}^{\text {st }} \\
\text { Test }\end{array}$ & $\begin{array}{c}\mathbf{5 B} \\
\mathbf{2}^{\text {nd }} \\
\text { Test }\end{array}$ & $\mathbf{6}$ \\
\hline STEELS: & & & & & & & & & \\
\hline 1018 & 0.93 & & & & 2.81 & & & & 3.61 \\
\hline A387 & 0.18 & & & & 0.58 & & & & 6.83 \\
\hline Corten B & 0.93 & & & & 0.55 & & & & 4.20 \\
\hline Ni ALLOYS: & & & & & & & & & \\
\hline 22 & 0.04 & 0.03 & 0.07 & 0.15 & 0.15 & 0.18 & 0.22 & 0.29 & 0.95 \\
\hline $22-$ Welded & 0.04 & & & & -0.01 & & & & 1.17 \\
\hline 59 & $<0.01$ & $<0.01$ & 0.11 & 0.11 & 0.18 & 0.22 & 0.40 & 0.40 & 1.72 \\
\hline 625 & 0.04 & 0.04 & 0.15 & 0.15 & 0.58 & 0.33 & 2.19 & 2.52 & 3.18 \\
\hline $625-W e l d e d$ & 0.11 & & & & -58 & & & & 2.74 \\
\hline 690 & 0.29 & 0.22 & 0.23 & 0.26 & 0.29 & 0.29 & 0.37 & 0.37 & 0.66 \\
\hline ALUMINUM BRONZE: & & & & & & & & & \\
\hline C-61400 & 0.07 & & 0.15 & & 1.02 & & & & 33.5 \\
\hline C-61400-Welded & 0.07 & & & & 0.84 & & & & 13.4 \\
\hline POLYMERS: & & & & & & & & & \\
\hline FEP & $<-0.01$ & & & & $<0.01$ & & $<-0.01$ & & $<0.01$ \\
\hline PTFE & $<0.01$ & & & & $<-0.01$ & & $<-0.01$ & & $<-0.01$ \\
\hline PEEK & 0.02 & & & & -0.01 & & -0.88 & & $(1)$ \\
\hline GRAPHITE & 0.07 & & & & 0.11 & & 0.11 & & -1.10 \\
\hline
\end{tabular}

Note 1 - This material disintegrated shortly after exposure at this test condition. 
Table 4-5: Summary of Corrosion Rates Measured Under Low Acid Condensate Conditions. All Values in mm/year.

\begin{tabular}{|l|c|c|c|c|}
\hline \multirow{2}{*}{ Alloy } & \multicolumn{4}{c|}{ Condition } \\
\cline { 2 - 5 } & $\mathbf{7}$ & $\mathbf{8 A}$ & $\mathbf{8 B}$ & $\mathbf{9}$ \\
\hline STEELS: & & & & \\
\hline 1018 & 0.07 & 0.29 & & 0.47 \\
\hline A387 & 0.04 & 0.29 & & 0.40 \\
\hline Corten B & 0.07 & 0.29 & & 0.58 \\
\hline STAINLESS STEELS: & & & & \\
\hline 304 & $<0.01$ & 0.02 & $<0.01$ & $<0.01$ \\
\hline 316 & $<0.01$ & 0.29 & $<0.01$ & $<0.01$ \\
\hline AL6XN & $<0.01$ & $<0.01$ & & $<0.01$ \\
\hline 2205 & $<0.01$ & $<0.01$ & $<0.01$ & $<0.01$ \\
\hline Ni ALLOYS: & & & & \\
\hline 22 & $<0.01$ & $<0.01$ & $<0.01$ & $<0.01$ \\
\hline 59 & & & $<0.01$ & $<0.01$ \\
\hline 600 & $<0.01$ & 0.07 & & 0.15 \\
\hline 601 & & & & $<0.01$ \\
\hline 625 & & & $<0.01$ & $<0.01$ \\
\hline 690 & & & $<0.01$ & $<0.01$ \\
\hline ALUMINUM BRONZE: & & & & \\
\hline C-61400 & $<0.01$ & 0.07 & & 0.15 \\
\hline ALUMINUM: & & & & \\
\hline 3003 & $<0.01$ & 0.18 & & 0.29 \\
\hline 6061 & $<0.01$ & 0.11 & & 0.29 \\
\hline POLYMERS: & & & & \\
\hline FEP & $<0.01$ & $<0.01$ & & $<0.01$ \\
\hline PTFE & $<0.01$ & $<0.01$ & & $<0.01$ \\
\hline PEEK & & & $<0.01$ & -0.04 \\
\hline GRAPHITE & & & & -0.07 \\
\hline & & & &
\end{tabular}

As previously discussed, the 60 percent $\mathrm{H}_{2} \mathrm{SO}_{4} / 121^{\circ} \mathrm{C}$ condition was included as a fairly aggressive screening test prior to receipt of all samples and completion of condensate composition and temperature calculations in order to make an initial assessment of the expected corrosion behavior. The corrosion rates for the stainless steels, aluminum alloys, and alloy 600 in this condition are very high, indicating they would generally not be suitable for the high acid conditions. This is consistent with other published data on these materials [Refs. 1 and 2] that demonstrate these alloys generally are not appropriate for higher $\mathrm{H}_{2} \mathrm{SO}_{4}$ concentrations and temperatures. Note there is reasonable reproducibility between the conditions that were re-tested.

The alloy 690 exhibited unusual behavior in the first test at 67 percent $\mathrm{H}_{2} \mathrm{SO}_{4}$ (Figure A3-a) in which the thickness loss increased abruptly between the fourth and fifth inspection. This change was not observed in the re-test (Figure A3-b). The reason for this is unknown, but the rate on each side of the change is similar $(0.26 \mathrm{~mm} / \mathrm{year}$ and 
$0.18 \mathrm{~mm} /$ year), so an average of these values is reported in Table 4-4 for this condition. A similar effect was observed for the 304, 316, and 2205 stainless steels during the first test in the $375 \mathrm{mg} / \mathrm{L} \mathrm{H}_{2} \mathrm{SO}_{4}$ solution (Figure A8-a) that was not observed during the retest (Figure A8-c). For these cases, the corrosion rates were generally less than 0.01 $\mathrm{mm} /$ year. It is possible that the protective scale was breached during inspection of the sample, but then quickly re-formed after exposure. The corrosion rate for the PEEK was negative $\left(-0.88 \mathrm{~mm} /\right.$ year) in the 74 percent $\mathrm{H}_{2} \mathrm{SO}_{4}$ solution, which indicates it absorbed acid. The PEEK material disintegrated quickly when the acid concentration was increased to 80 percent $\mathrm{H}_{2} \mathrm{SO}_{4}$. Similarly, the negative corrosion rate for the graphite in this condition indicates it absorbed solution during this exposure. The FEP and PTFE polymeric materials exhibited very good resistance to degradation under the full range of low and high acid conditions. The graphite also demonstrated good resistance except for absorption of solution at the most aggressive high acid condition.

As expected, the corrosion rate of the alloys increased with increasing acid concentration and temperature. This is shown in Figures 4-2 through 4-4 for the high acid concentrations for the nickel alloys, steels, and aluminum bronze, and Figure 4-5 for the steels, aluminum alloys, and aluminum bronze alloy in the low acid concentrations (i.e., for cases in which a significant corrosion rate was observed). In these plots, an average corrosion rate was used for tests conducted in duplicate. Note that an increase in solution temperature in these plots also corresponds to an increase in acid concentration. The acid concentration associated with each solution temperature is noted in the figures. All materials except steels exhibit acceptable corrosion rates in the low acid concentrations. For the high acid concentrations, the C61400 aluminum bronze alloy exhibits acceptable corrosion rates $(<0.15 \mathrm{~mm} / \mathrm{year}$ ) when the acid concentration is less than 67 percent $\mathrm{H}_{2} \mathrm{SO}_{4}$ and the temperature is below $67^{\circ} \mathrm{C}$. However, the corrosion rates are unacceptable in more aggressive conditions. The corrosion rates of the steels are unacceptable in the high acid concentrations and temperatures. The nickel alloys 22, 59, and 690 exhibited acceptable corrosion rates ( $\leq 0.4 \mathrm{~mm} / \mathrm{year}$ ) for all but the most aggressive condition tested. Welding of the nickel and aluminum bronze alloys did not have a significant influence on the corrosion behavior under these test conditions. 


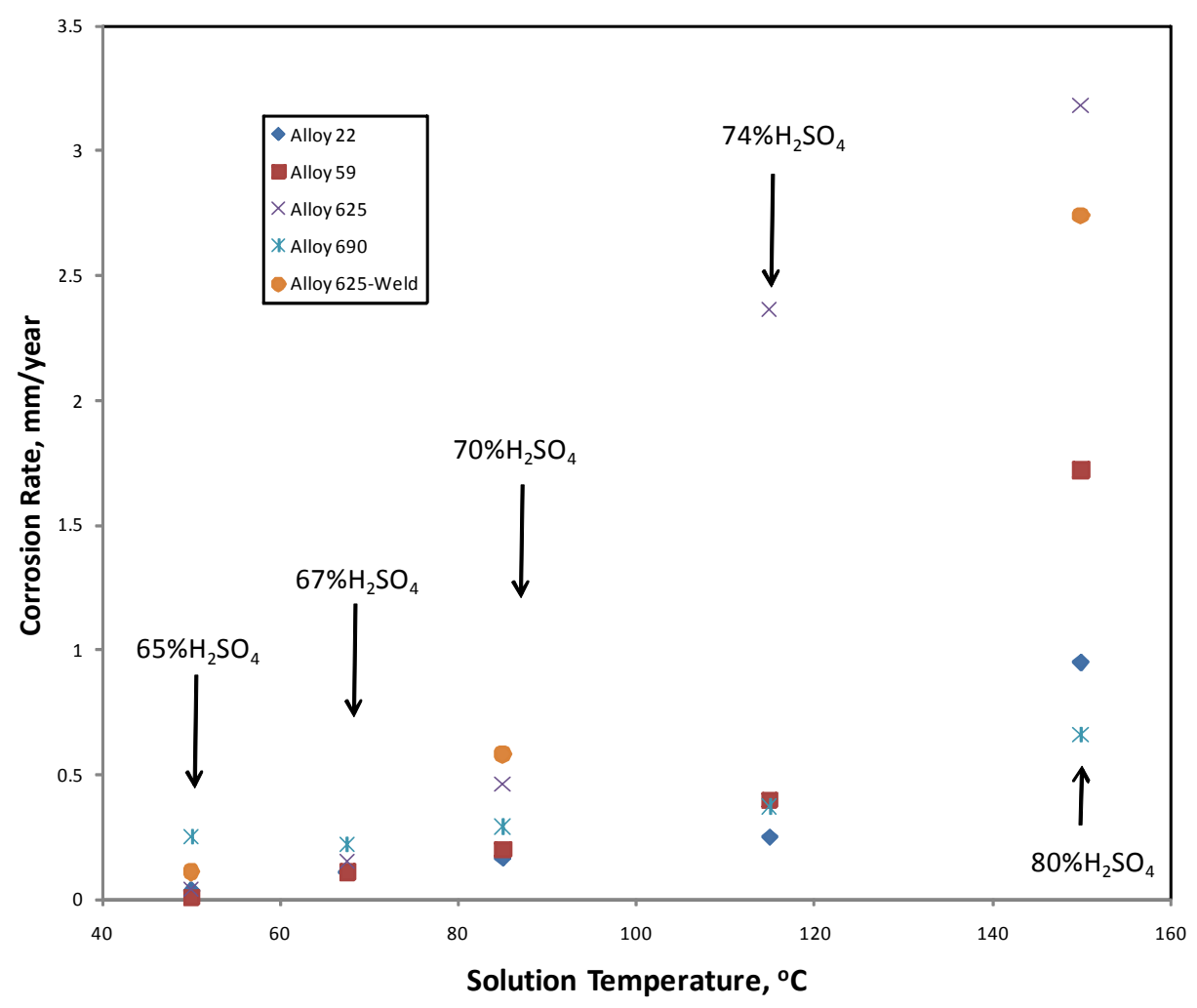

Figure 4-2: Corrosion Rate of Nickel Alloys as a Function of Temperature. Results Shown are for the High Acid Test Conditions.

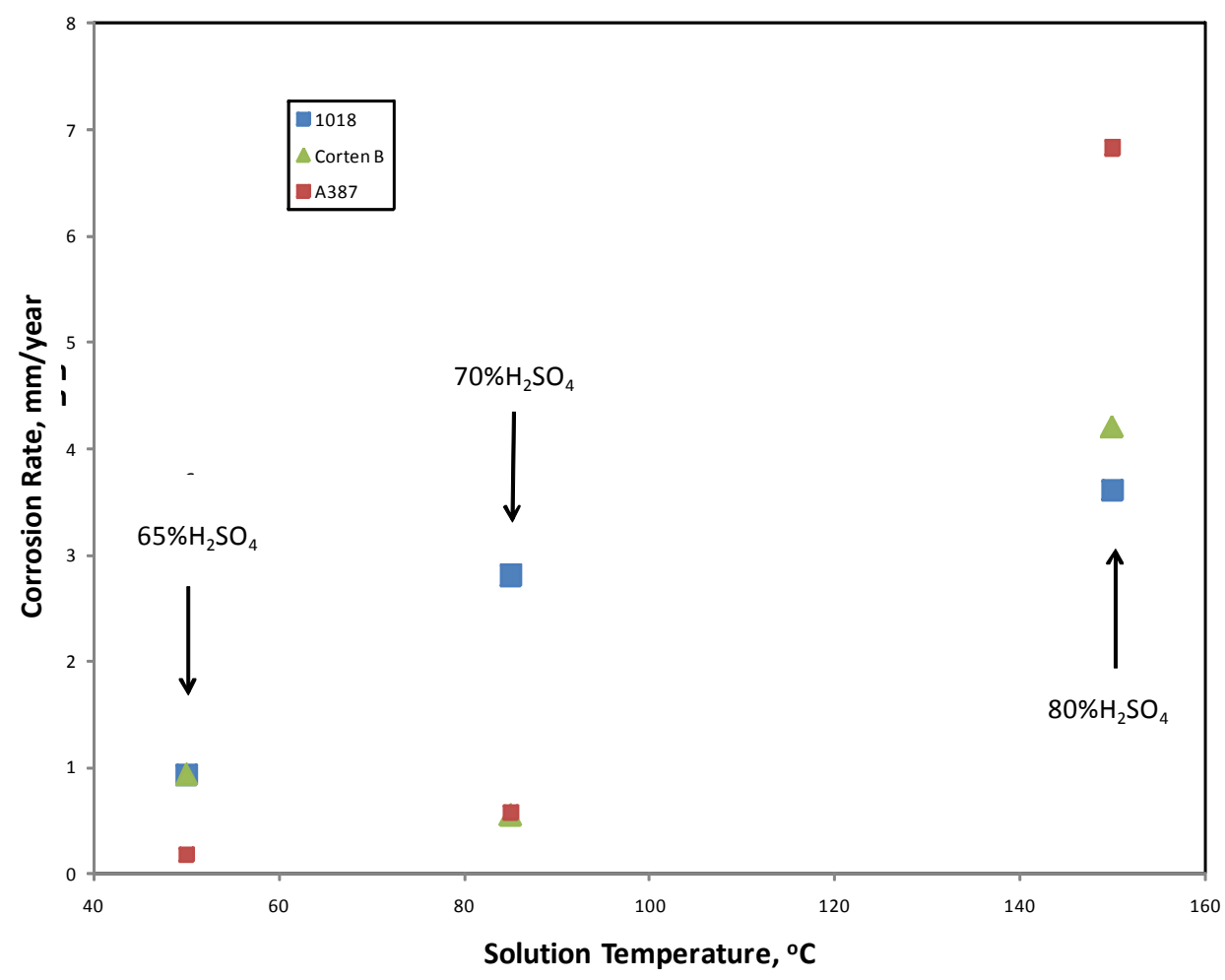

Figure 4-3: Corrosion Rate of Steels as a Function of Temperature. Results Shown are for the High Acid Test Conditions. 


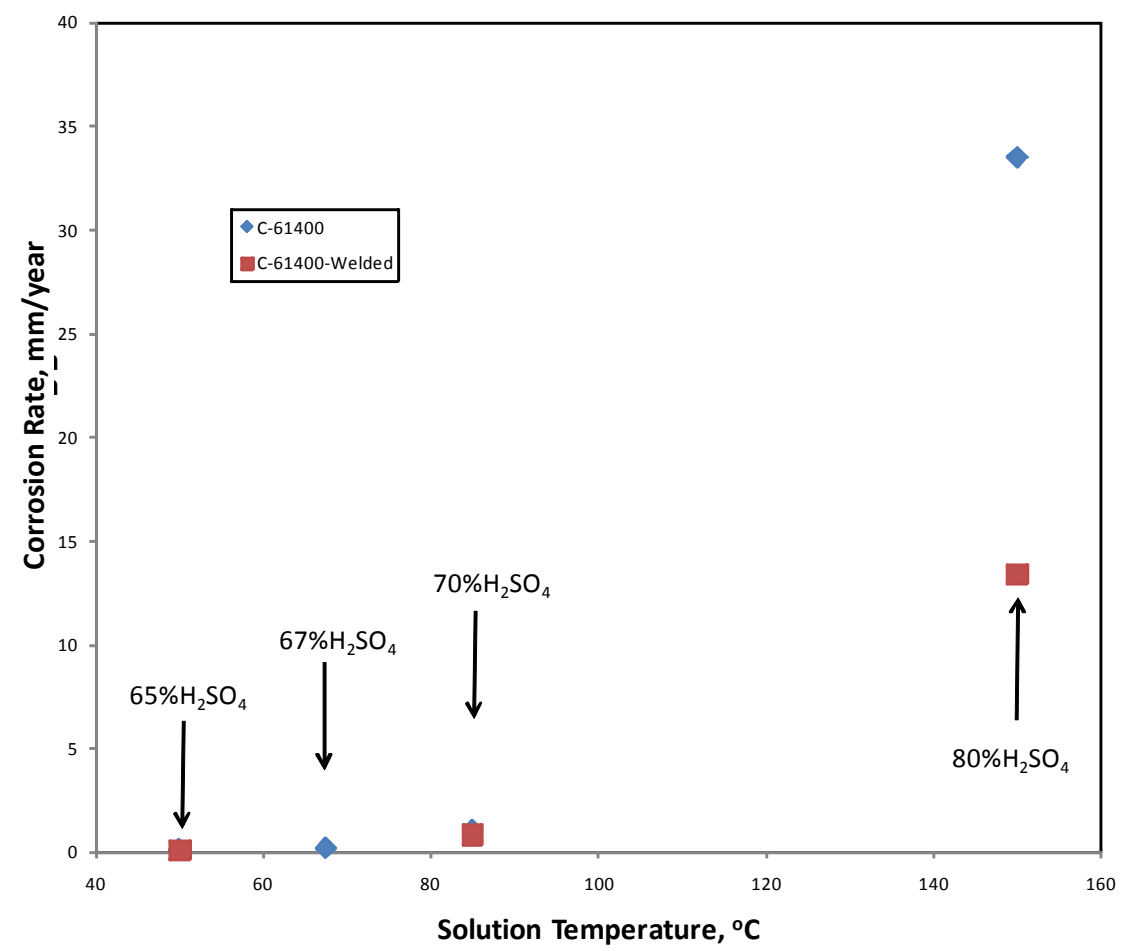

Figure 4-4: Corrosion Rate of Aluminum Bronze Alloy as a Function of Temperature. Results Shown are for the High Acid Test Conditions.

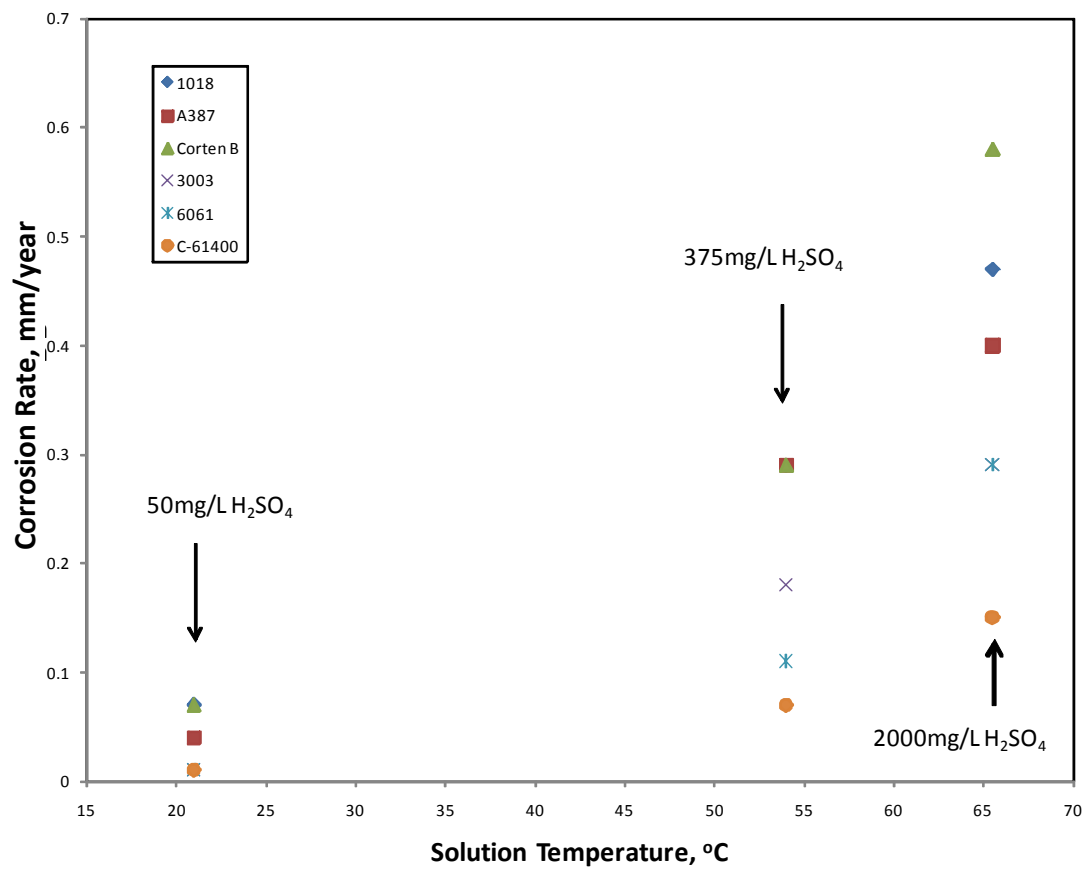

Figure 4-5: Corrosion Rates of Steels, Aluminum Alloys, and Aluminum Bronze Alloy as a Function of Temperature. Results Shown are for the Low Acid Test Conditions. 
The corrosion rate data described above indicate that all materials except steels would provide acceptable service life in the low acid conditions, and the nickel alloys 22, 59, 690 along with polymeric materials FEP and PTFE are the best materials for the high acid conditions. Visual examination of these materials is important to ensure they did not experience localized corrosion. None of the alloys that exhibited low corrosion rates in the low acid solution exhibited any significant evidence of corrosion. Examples of this for the stainless steels, polymers, and graphite from $2000 \mathrm{mg} / \mathrm{L} \mathrm{H}_{2} \mathrm{SO}_{4}$ solution are shown in Figure 4-6. Figures 4-7 through 4-9 show photographs of nickel alloys 690, 22, and 59 in the high acid solutions. Note that the corrosion is primarily uniform, thus justifying the use of a general corrosion rate. Alloy 690 exhibits evidence of general corrosion at all acid concentrations. This is consistent with the corrosion rate data in Table 4-4 and Figure 4-2 in which the corrosion rate of this alloy shows the lowest dependence on solution composition and temperature. Alloys 22 and 59 (Figures 4-8 and 4-9) show no visible signs of corrosion at 65 and 67 percent $\mathrm{H}_{2} \mathrm{SO}_{4}$ concentrations. Evidence for corrosion begins at the 70 percent $\mathrm{H}_{2} \mathrm{SO}_{4}$ level and increases in severity with increasing acid concentration. Alloy 625 (Figure 4-10) shows evidence of corrosion starting at the 67 percent $\mathrm{H}_{2} \mathrm{SO}_{4}$ concentration level, and corrosion becomes rather extensive with increasing acid concentration and temperature. These observations are consistent with the results shown in Figure 4-2.

Figures 4-11 through 4-13 show LOM photomicrographs of alloys 690,22 , and 59 after exposure to the 74 percent $\mathrm{H}_{2} \mathrm{SO}_{4}$ solution. Figures 4-11a and 4-12a show low magnification cross-sectional views of the alloys 690 and 22 in the metallographic mounts. There is no evidence of localized corrosion across the surface of the samples. The higher magnification views provided in these figures also demonstrate there is no localized corrosion associated with any particular microstructural features (e.g., no localized grain boundary corrosion). The sample of alloy 690 shown in Figure 4-13 exhibits accelerated corrosion on a portion of the sample, suggesting this alloy is probably at the useful limit when the acid concentration is 74 percent $\mathrm{H}_{2} \mathrm{SO}_{4}$. 


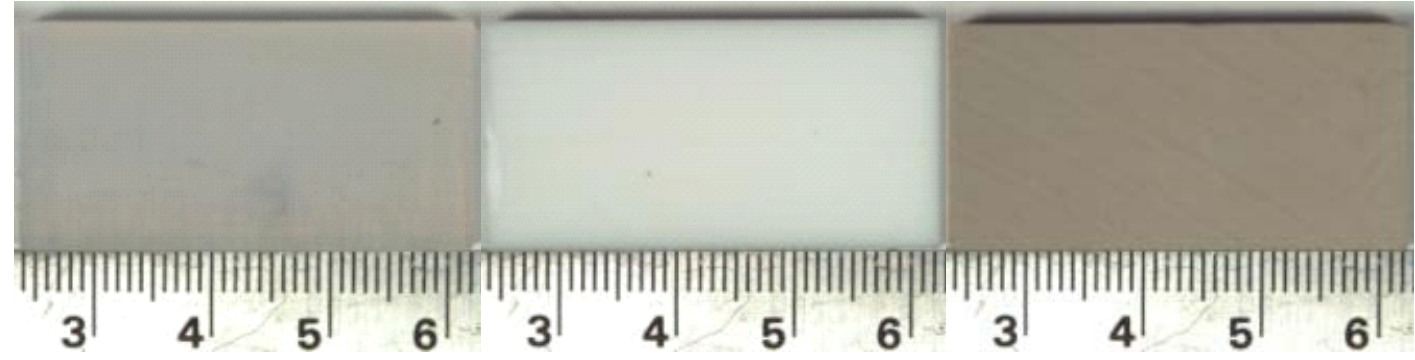

Left: FEP - $2000 \mathrm{mg} / \mathrm{L} \mathrm{H}_{2} \mathrm{SO}_{4} 65.5^{\circ} \mathrm{C}$

Middle: PTFE - $2000 \mathrm{mg} / \mathrm{L} \mathrm{H}_{2} \mathrm{SO}_{4} 65.5^{\circ} \mathrm{C}$

Right: PEEK - $2000 \mathrm{mg} / \mathrm{L} \mathrm{H}_{2} \mathrm{SO}_{4} 65.5^{\circ} \mathrm{C}$

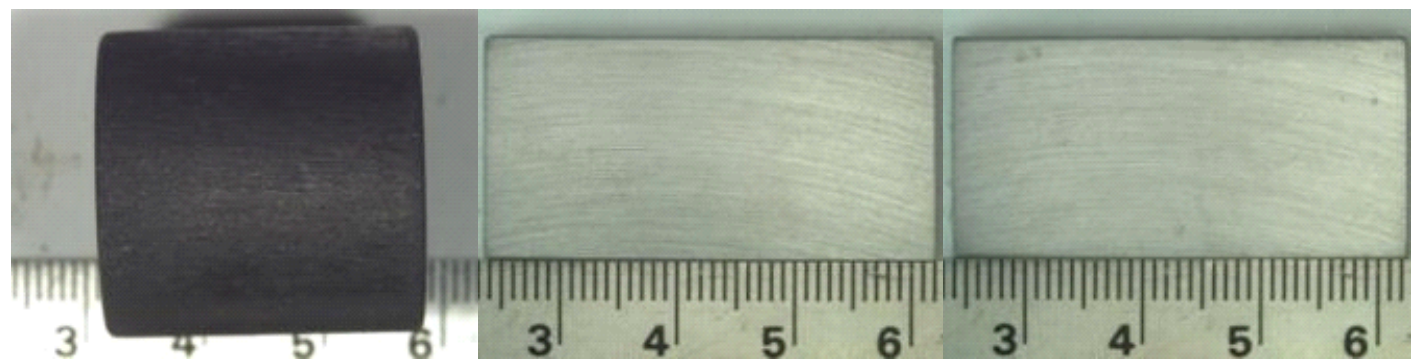

Left: Graphite $-2000 \mathrm{mg} / \mathrm{L} \mathrm{H}_{2} \mathrm{SO}_{4} 65.5^{\circ} \mathrm{C}$

Middle: AL6XN - $2000 \mathrm{mg} / \mathrm{L} \mathrm{H}_{2} \mathrm{SO}_{4} 65.5^{\circ} \mathrm{C}$

Right: $2205-2000 \mathrm{mg} / \mathrm{L} \mathrm{H}_{2} \mathrm{SO}_{4} 65.5^{\circ} \mathrm{C}$

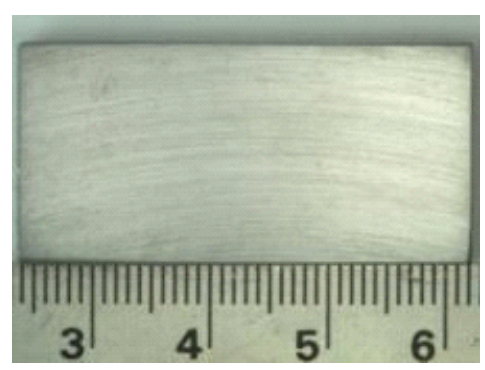

Left: $316-2000 \mathrm{mg} / \mathrm{L} \mathrm{H}_{2} \mathrm{SO}_{4} 65.5^{\circ} \mathrm{C}$

Figure 4-6: Photographs of Various Materials from the Low Acid Test Condition. 


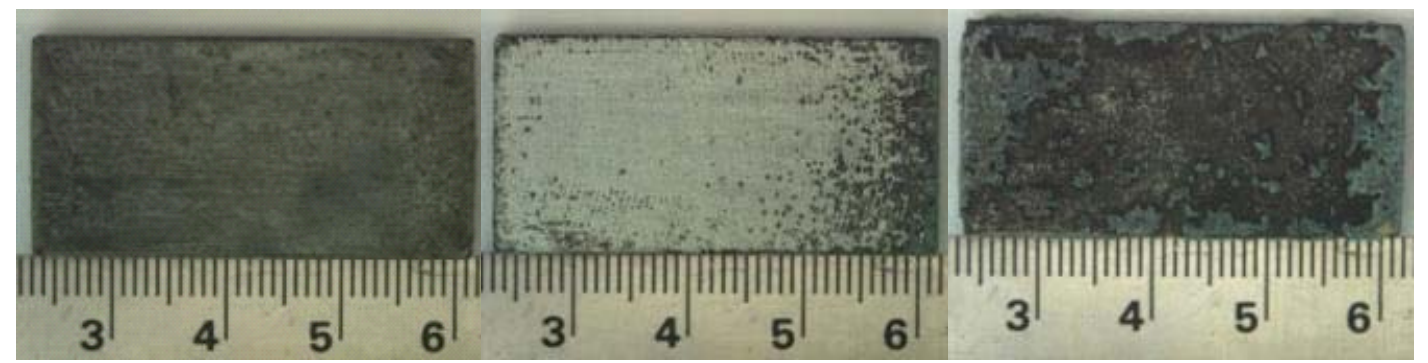

Left: $690-65 \% \mathrm{H}_{2} \mathrm{SO}_{4} 50^{\circ} \mathrm{C}\left(1^{\text {st }}\right.$ test)

Middle: $690-65 \% \mathrm{H}_{2} \mathrm{SO}_{4} 50^{\circ} \mathrm{C}$ ( $2^{\text {nd }}$ test)

Right: $690-67 \% \mathrm{H}_{2} \mathrm{SO}_{4} 67.5^{\circ} \mathrm{C}\left(1^{\text {st }}\right.$ test)

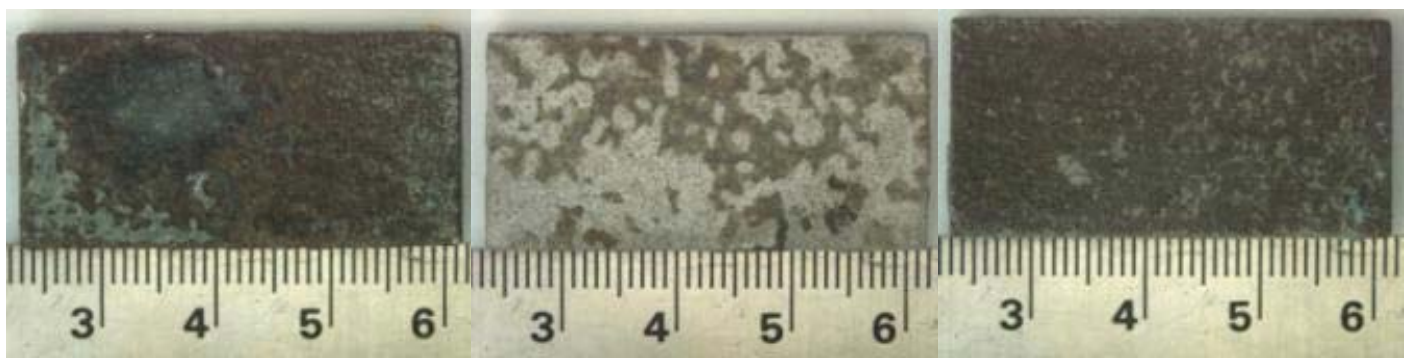

Left: $690-67 \% \mathrm{H}_{2} \mathrm{SO}_{4} 67.5^{\circ} \mathrm{C}$ ( $2^{\text {nd }}$ test) Middle: $690-70 \% \mathrm{H}_{2} \mathrm{SO}_{4} 85^{\circ} \mathrm{C}$ ( $1^{\text {st }}$ test)

Right: $690-70 \% \mathrm{H}_{2} \mathrm{SO}_{4} 85^{\circ} \mathrm{C}$ ( ${ }^{\text {nd }}$ test)

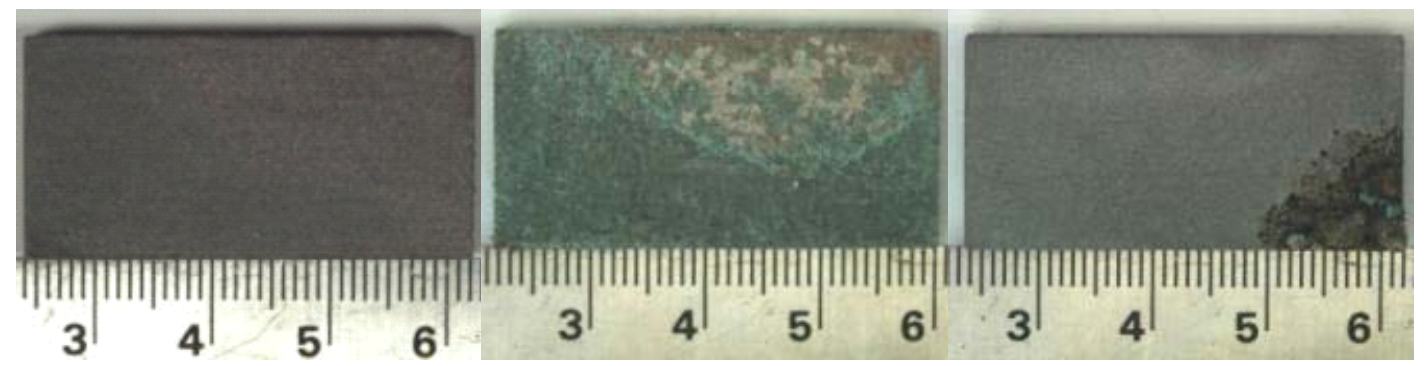

Left: 690 - $74 \% \mathrm{H}_{2} \mathrm{SO}_{4} 115^{\circ} \mathrm{C}$ ( $1^{\text {st }}$ test)

Middle: $690-74 \% \mathrm{H}_{2} \mathrm{SO}_{4} 115^{\circ} \mathrm{C}\left(2^{\text {nd }}\right.$ te st $)$

Right: $690-80 \% \mathrm{H}_{2} \mathrm{SO}_{4} 150^{\circ} \mathrm{C}$

Figure 4-7: Photographs of Samples of Alloy 690 from the High Acid Test Conditions. 


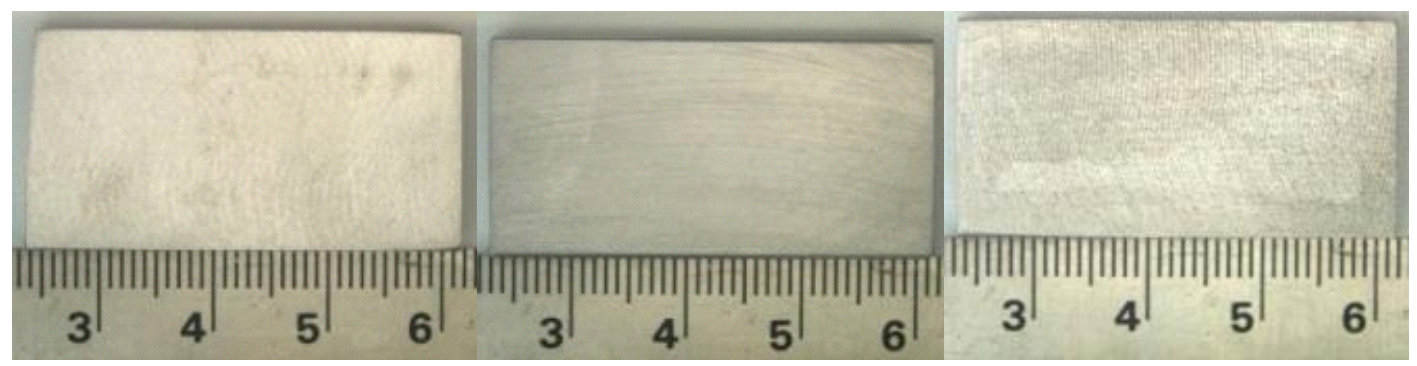

Left: Alloy $22-65 \% \mathrm{H}_{2} \mathrm{SO}_{4} 50^{\circ} \mathrm{C}$ ( $1^{\text {st }}$ test)

Middle: Alloy $22-65 \% \mathrm{H}_{2} \mathrm{SO}_{4} 50^{\circ} \mathrm{C}$ ( $2^{\text {nd }}$ test $)$

Right: Alloy $22-67 \% \mathrm{H}_{2} \mathrm{SO}_{4} 67.5^{\circ} \mathrm{C}$ ( $1^{\text {st }}$ test)

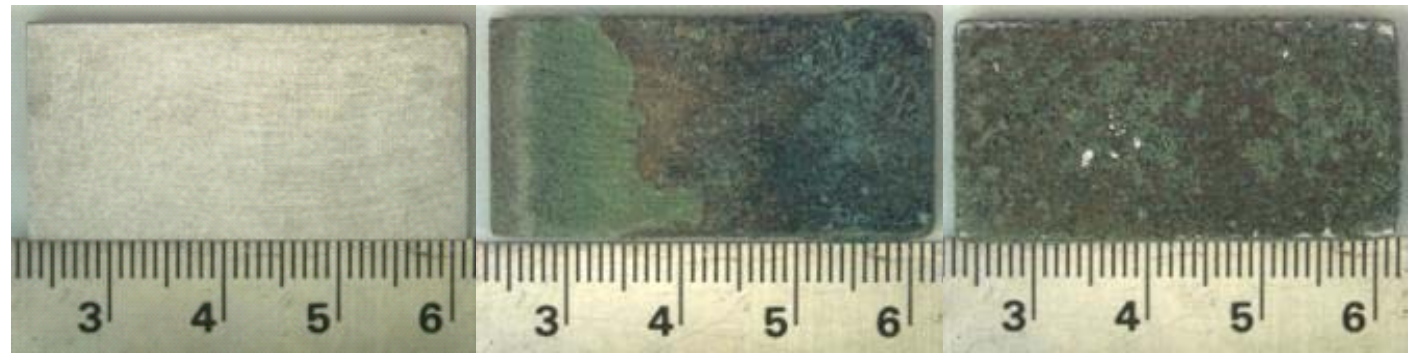

Left: Alloy $22-67 \% \mathrm{H}_{2} \mathrm{SO}_{4} 67.5^{\circ} \mathrm{C}$ ( $2^{\text {nd }}$ test) Middle: Alloy $22-70 \% \mathrm{H}_{2} \mathrm{SO}_{4} 85^{\circ} \mathrm{C}\left(1^{\text {st }}\right.$ test $)$ Right: Alloy $22-70 \% \mathrm{H}_{2} \mathrm{SO}_{4} 85^{\circ} \mathrm{C}$ ( $2^{\text {nd }}$ test)

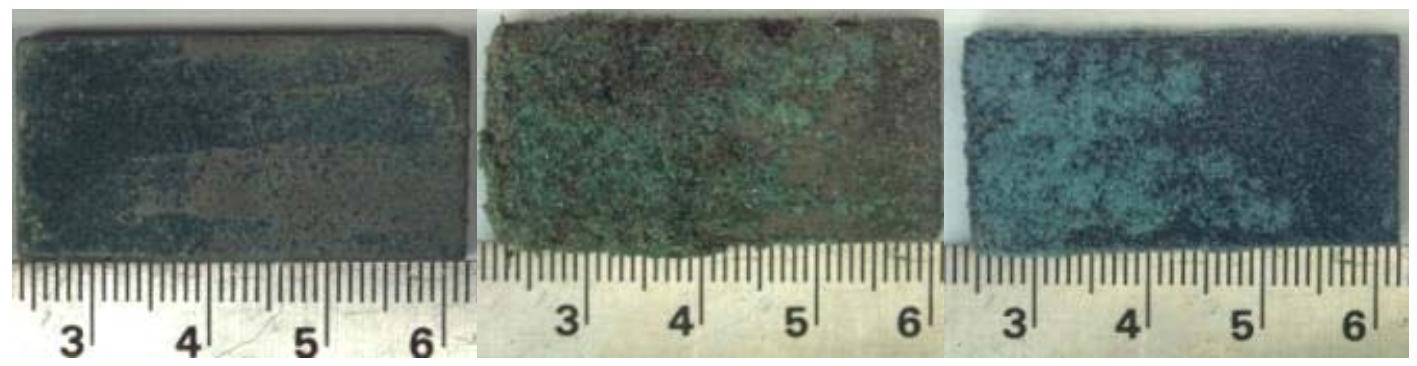

Left: Alloy $22-74 \% \mathrm{H}_{2} \mathrm{SO}_{4} 115^{\circ} \mathrm{C}\left(1^{\text {st }}\right.$ test) Middle: Alloy $22-74 \% \mathrm{H}_{2} \mathrm{SO}_{4} 115^{\circ} \mathrm{C}$ ( $2^{\text {nd }}$ test)

Right: Alloy $22-80 \% \mathrm{H}_{2} \mathrm{SO}_{4} 150^{\circ} \mathrm{C}$

Figure 4-8: Photographs of Samples of Alloy 22 from the High Acid Test Conditions. 


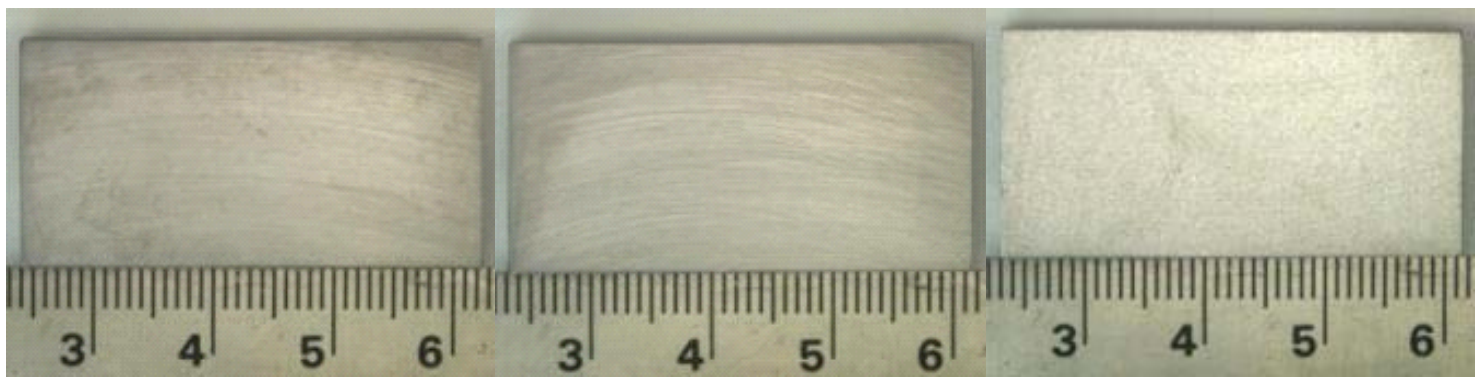

Left: Alloy $59-65 \% \mathrm{H}_{2} \mathrm{SO}_{4} 50^{\circ} \mathrm{C}\left(1^{\text {st }}\right.$ test) Middle: Alloy $59-65 \% \mathrm{H}_{2} \mathrm{SO}_{4} 50^{\circ} \mathrm{C}$ ( $2^{\text {nd }}$ test) Right: Alloy $59-67 \% \mathrm{H}_{2} \mathrm{SO}_{4} 67.5^{\circ} \mathrm{C}\left(1^{\text {st }}\right.$ test)

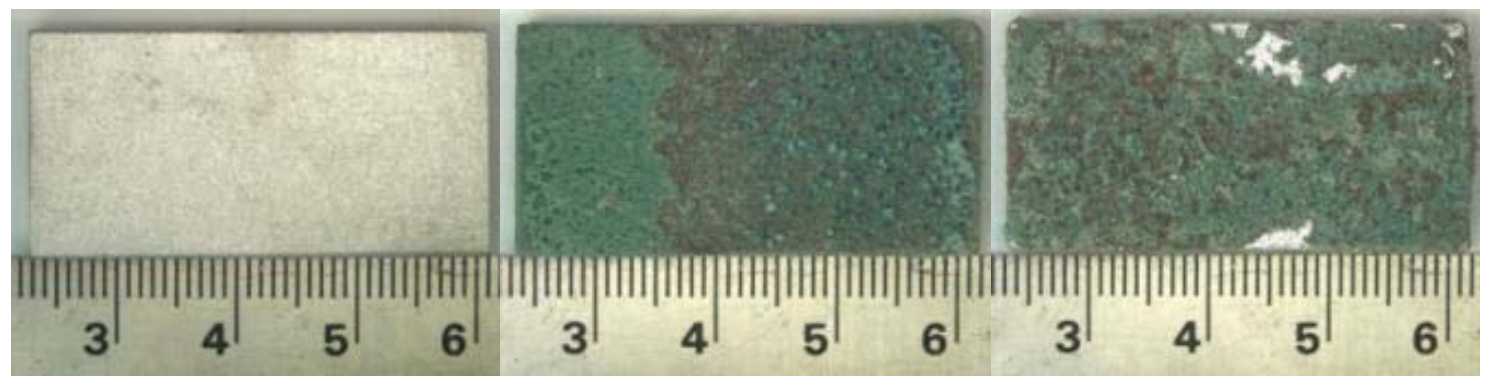

Left: Alloy $59-67 \% \mathrm{H}_{2} \mathrm{SO}_{4} 67.5^{\circ} \mathrm{C}\left(2^{\text {nd }}\right.$ test) Middle: Alloy $59-70 \% \mathrm{H}_{2} \mathrm{SO}_{4} 85^{\circ} \mathrm{C}$ ( $1^{\text {st }}$ test) Right: Alloy $59-70 \% \mathrm{H}_{2} \mathrm{SO}_{4} 85^{\circ} \mathrm{C}\left(2^{\text {nd }}\right.$ test)

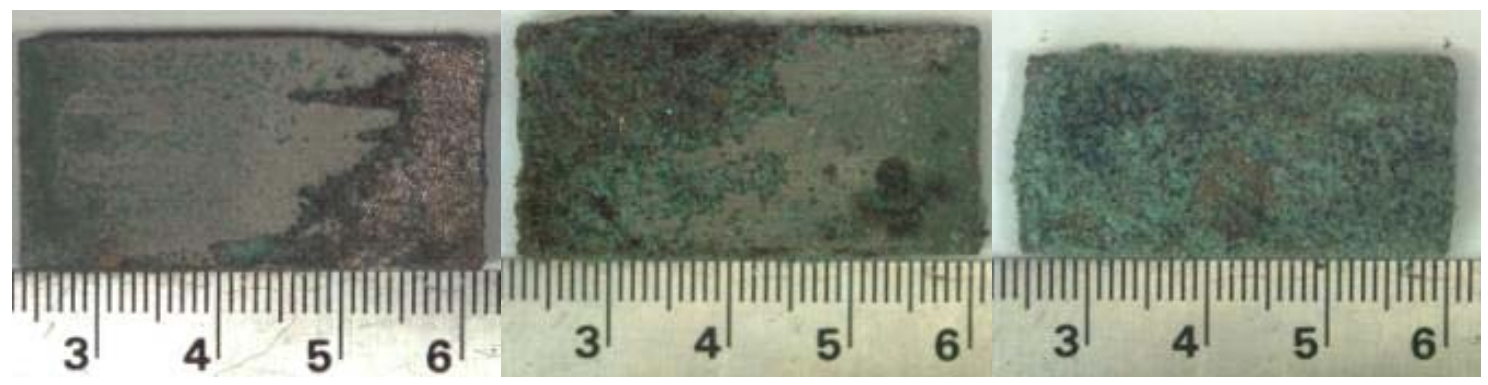

Left: Alloy $59-74 \% \mathrm{H}_{2} \mathrm{SO}_{4} 115^{\circ} \mathrm{C}\left(1^{\text {st }}\right.$ test) Middle: Alloy $59-74 \% \mathrm{H}_{2} \mathrm{SO}_{4} 115^{\circ} \mathrm{C}$ ( $2^{\text {nd }}$ test) Right: Alloy $59-80 \% \mathrm{H}_{2} \mathrm{SO}_{4} 150^{\circ} \mathrm{C}$

Figure 4-9: Photographs of Samples of Alloy 59 from the High Acid Test Conditions. 


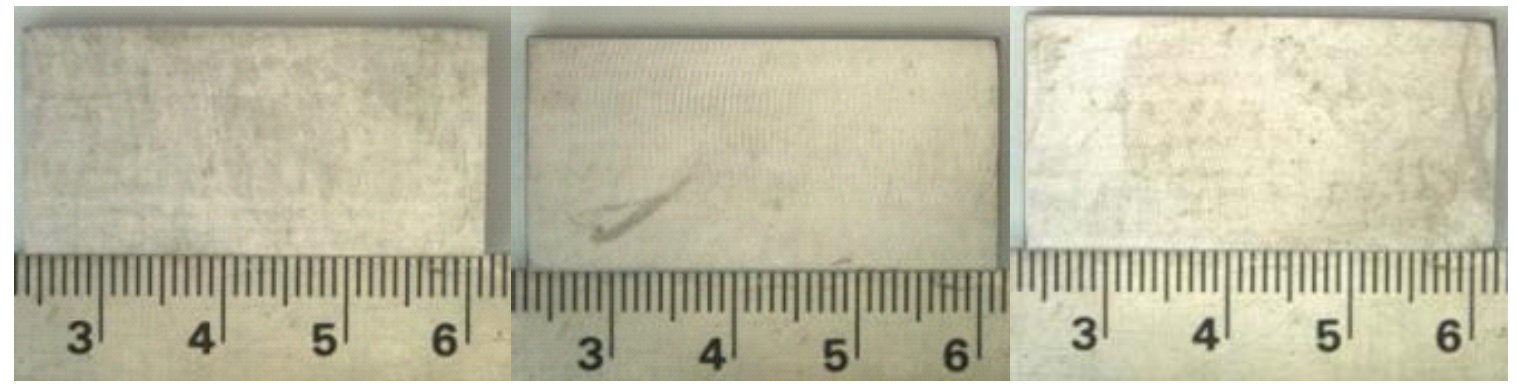

Left: $625-65 \% \mathrm{H}_{2} \mathrm{SO}_{4} 50^{\circ} \mathrm{C}\left(1^{\text {st }}\right.$ test $)$

Middle: $625-65 \% \mathrm{H}_{2} \mathrm{SO}_{4} 50^{\circ} \mathrm{C}$ ( $2^{\text {nd }}$ test)

Right: $625-67 \% \mathrm{H}_{2} \mathrm{SO}_{4} 67.5^{\circ} \mathrm{C}\left(1^{\text {st }}\right.$ test $)$

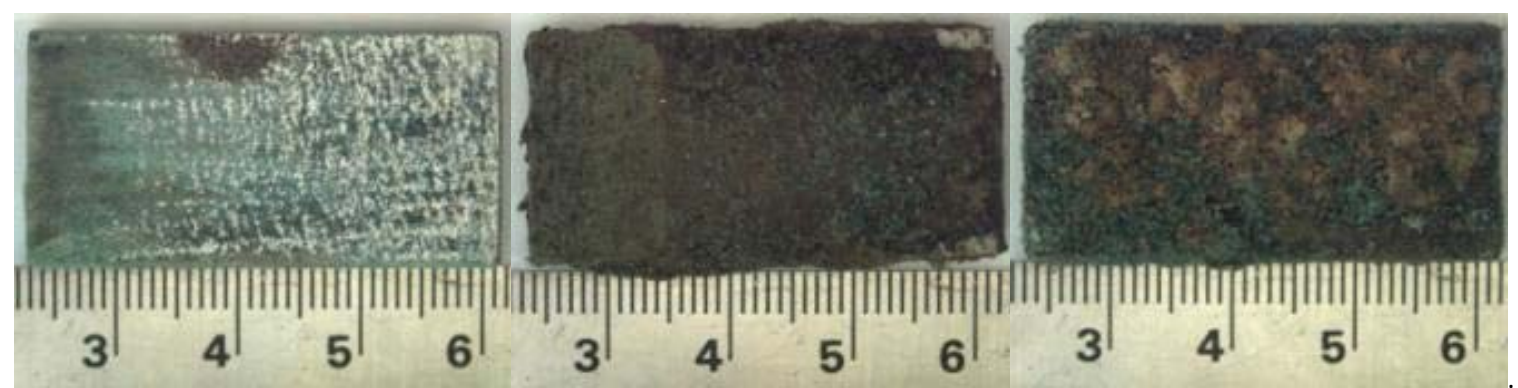

Left: $625-67 \% \mathrm{H}_{2} \mathrm{SO}_{4} 67.5^{\circ} \mathrm{C}$ ( $2^{\text {nd }}$ te st)

Middle: $625-70 \% \mathrm{H}_{2} \mathrm{SO}_{4} 85^{\circ} \mathrm{C}$ ( $1^{\text {st }}$ test)

Right: $625-70 \% \mathrm{H}_{2} \mathrm{SO}_{4} 85^{\circ} \mathrm{C}$ ( ${ }^{\text {nd }}$ test)

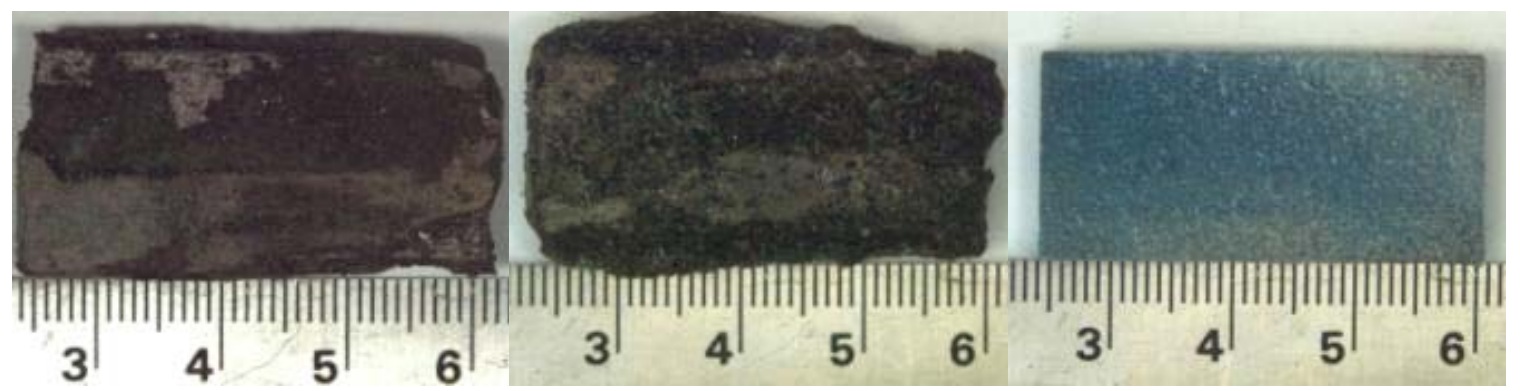

Left: $625-74 \% \mathrm{H}_{2} \mathrm{SO}_{4} 115^{\circ} \mathrm{C}\left(1^{\text {st }}\right.$ test)

Middle: $625-74 \% \mathrm{H}_{2} \mathrm{SO}_{4} 115^{\circ} \mathrm{C}$ (2 $2^{\text {nd }}$ te st)

Right: $80 \% \mathrm{H}_{2} \mathrm{SO}_{4} 150^{\circ} \mathrm{C}$

Figure 4-10: Photographs of Samples of Alloy 625 from the High Acid Test Conditions. 


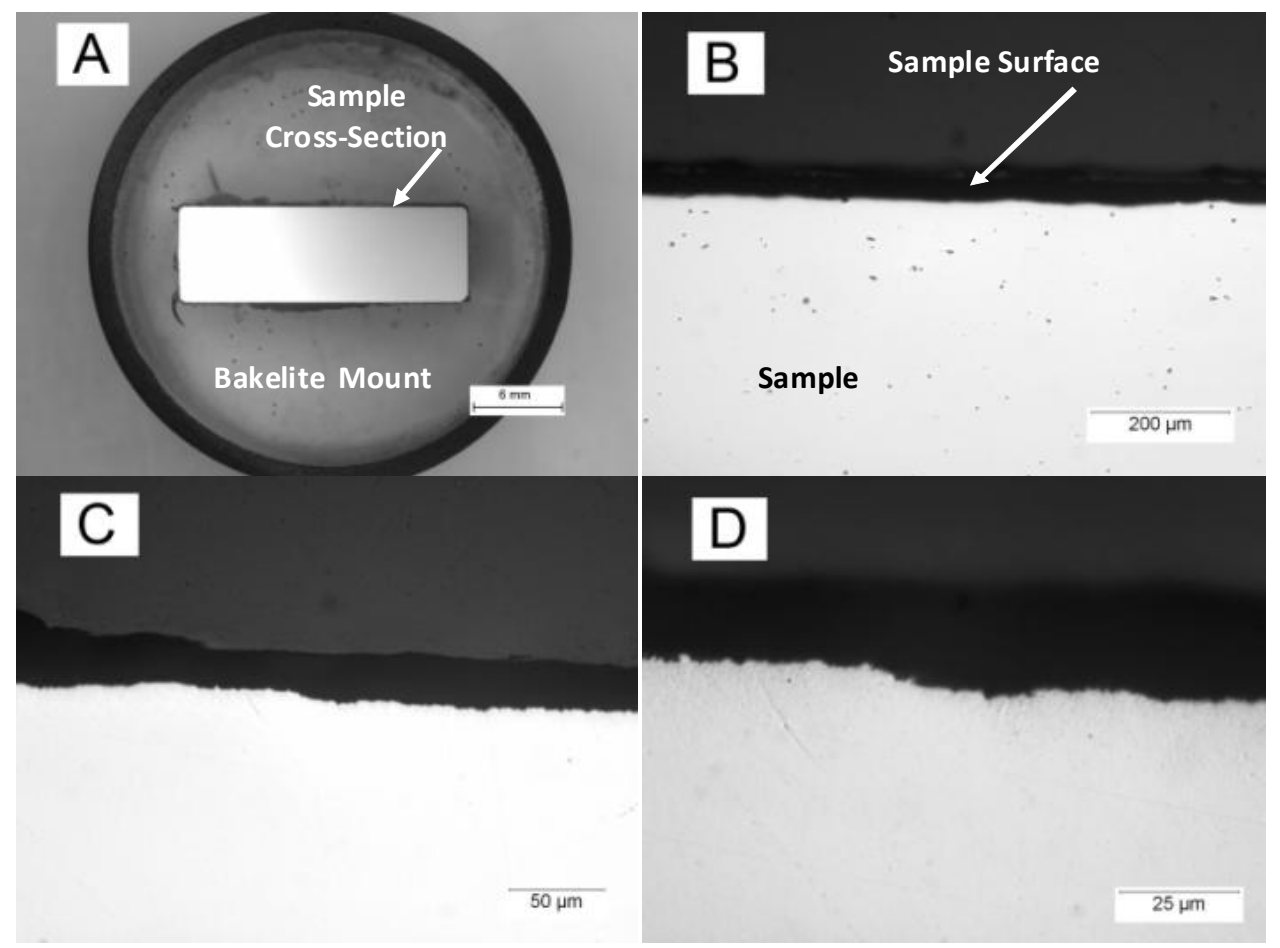

Figure 4-11: Photomicrographs of 690 Following Corrosion Testing at $115^{\circ} \mathrm{C}$ in 74 percent $\mathrm{H}_{2} \mathrm{SO}_{4}$. a) Image Showing Mounted Cross-Section, b) $5 x$ Objective, c) 20x Objective, and d) 50x Objective.
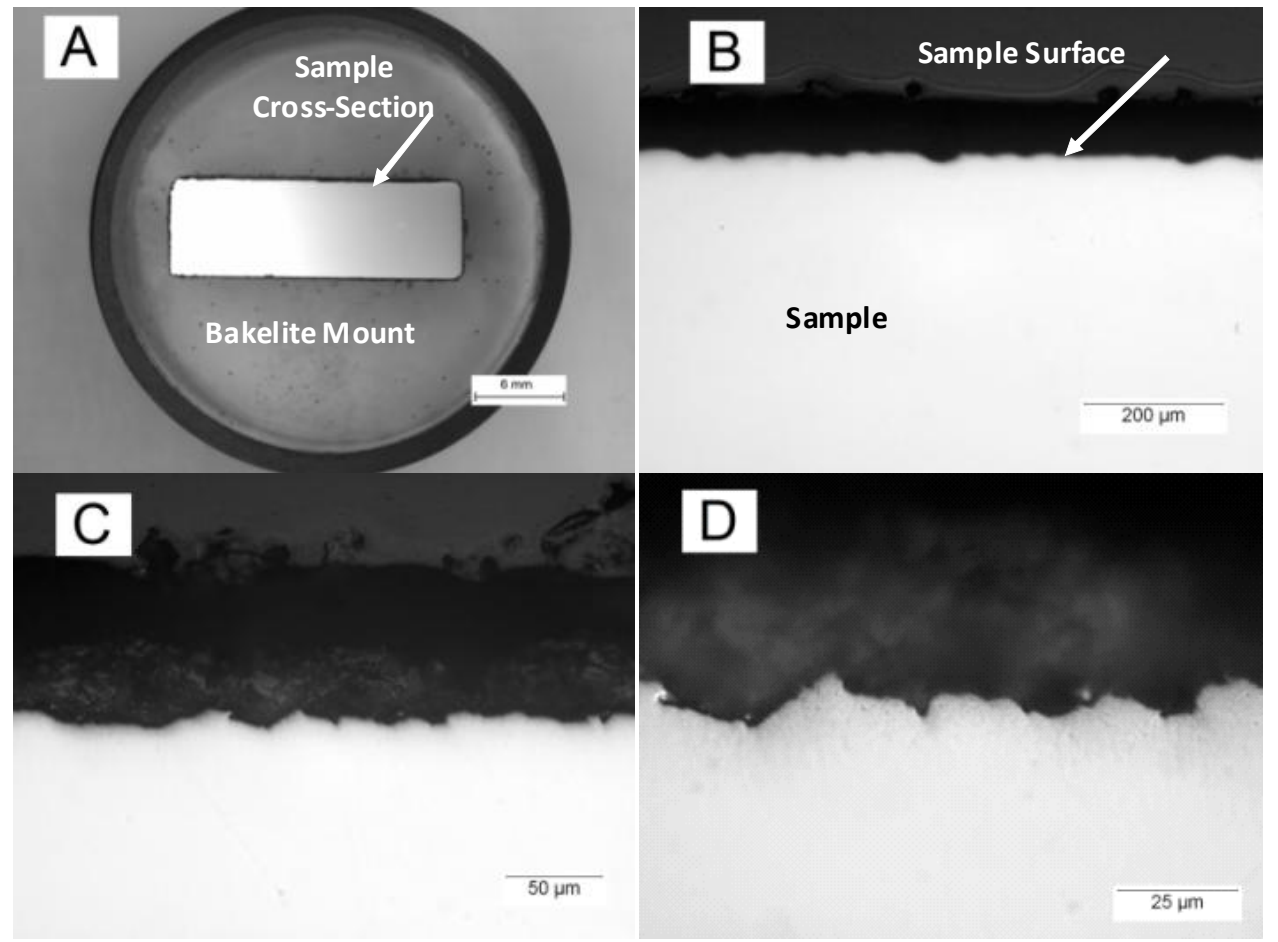

Figure 4-12: Photomicrographs of Alloy 22 Following Corrosion Testing at $115^{\circ} \mathrm{C}$ in 74 Percent $\mathrm{H}_{2} \mathrm{SO}_{4}$. a) Image Showing Mounted Cross-Section, b) $5 x$ Objective, c) 20x Objective, and d) 50x Objective. 


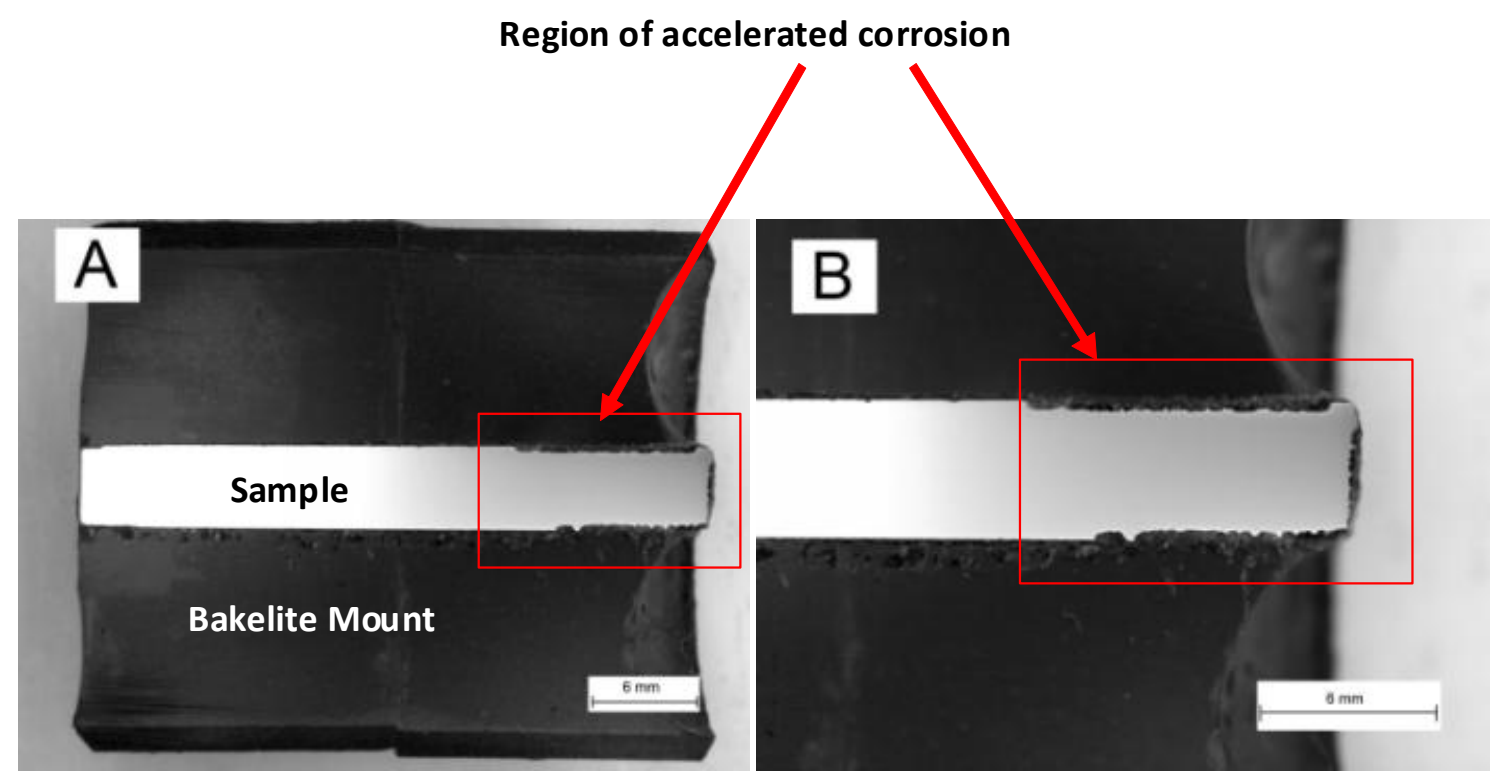

Figure 4-13: Photomicrographs of Alloy 59 Following Corrosion Testing at $115^{\circ} \mathrm{C}$ in 74 Percent $\mathrm{H}_{2} \mathrm{SO}_{4}$. a) Macro-Image Showing Mounted CrossSection, b) Higher Magnification of Mounted Cross-Section Showing Large Areas of Corroded Material.

Figures 4-14 through 4-17 show photographs of the graphite and polymer samples. The FEP and PTFE show no visible signs of degradation over the entire $\mathrm{H}_{2} \mathrm{SO}_{4}$ concentration range for the high acid conditions, which is consistent with the corrosion rate data provided in Table 4-4. The PEEK shows evidence of degradation at 74 percent $\mathrm{H}_{2} \mathrm{SO}_{4}$ and completely disintegrated at the highest acid concentration, which is also consistent with the corrosion rate data. The graphite shows no evidence of degradation, but the data in Table 4-4 suggests that solution absorption occurred at the 74 percent $\mathrm{H}_{2} \mathrm{SO}_{4}$ level.

Figures 4-18 and 4-19 show the Teflon coated samples after testing, and the weight change results are provided in Figures A10-a and A10-b. The samples from the low acid test conditions show no visible signs of degradation. However, a slight weight gain is observed during the $375 \mathrm{mg} / \mathrm{L} \mathrm{H}_{2} \mathrm{SO}_{4}-54^{\circ} \mathrm{C}$ condition, while a significant weight loss is observed during the $2000 \mathrm{mg} / \mathrm{L} \mathrm{H}_{2} \mathrm{SO}_{4}-65.5^{\circ} \mathrm{C}$ condition. Weight change results for the high acid test conditions could only be obtained for the 65 percent and 70 percent $\mathrm{H}_{2} \mathrm{SO}_{4}$ test condition because the coating exposed to the 80 percent $\mathrm{H}_{2} \mathrm{SO}_{4}$ test condition deteriorated rapidly (as shown in Figure 4-19). The coatings tested in the 65 
percent $\mathrm{H}_{2} \mathrm{SO}_{4}$ solution showed only a moderate weight loss (Figure A10-b) and the samples showed no visible signs of degradation (Figure 4-19). Significant weight gain was observed for the 70 percent $\mathrm{H}_{2} \mathrm{SO}_{4}$ test condition, particularly for the last weight change measurement on the MP501 coating. This weight change is consistent with the blistering observed on this coating shown in Figure 4-19. The blistering occurs when solution permeates the coating (thus accounting for the observed weight gain) and leads to subsequent corrosion of the underlying substrate.

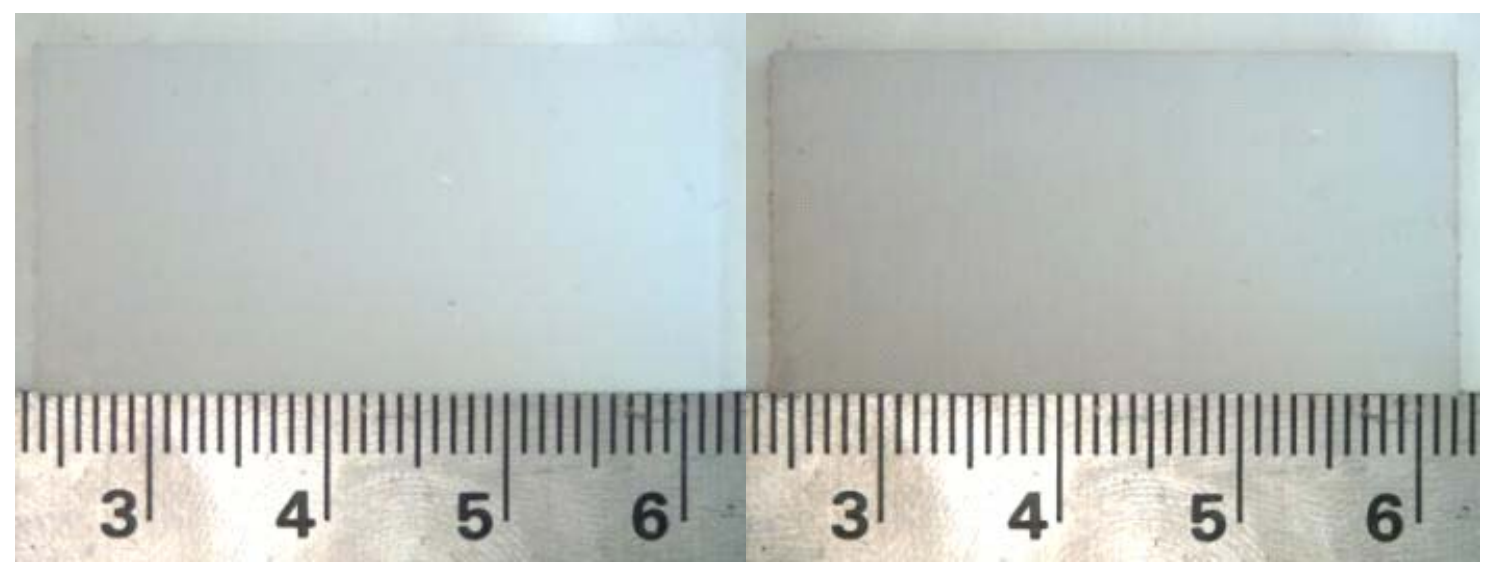

Left: FEP $-65 \% \mathrm{H}_{2} \mathrm{SO}_{4} 50^{\circ} \mathrm{C}\left(1^{\text {st }}\right.$ test)

Right: FEP - $70 \% \mathrm{H}_{2} \mathrm{SO}_{4} 85^{\circ} \mathrm{C}\left(1^{\text {st }}\right.$ test $)$

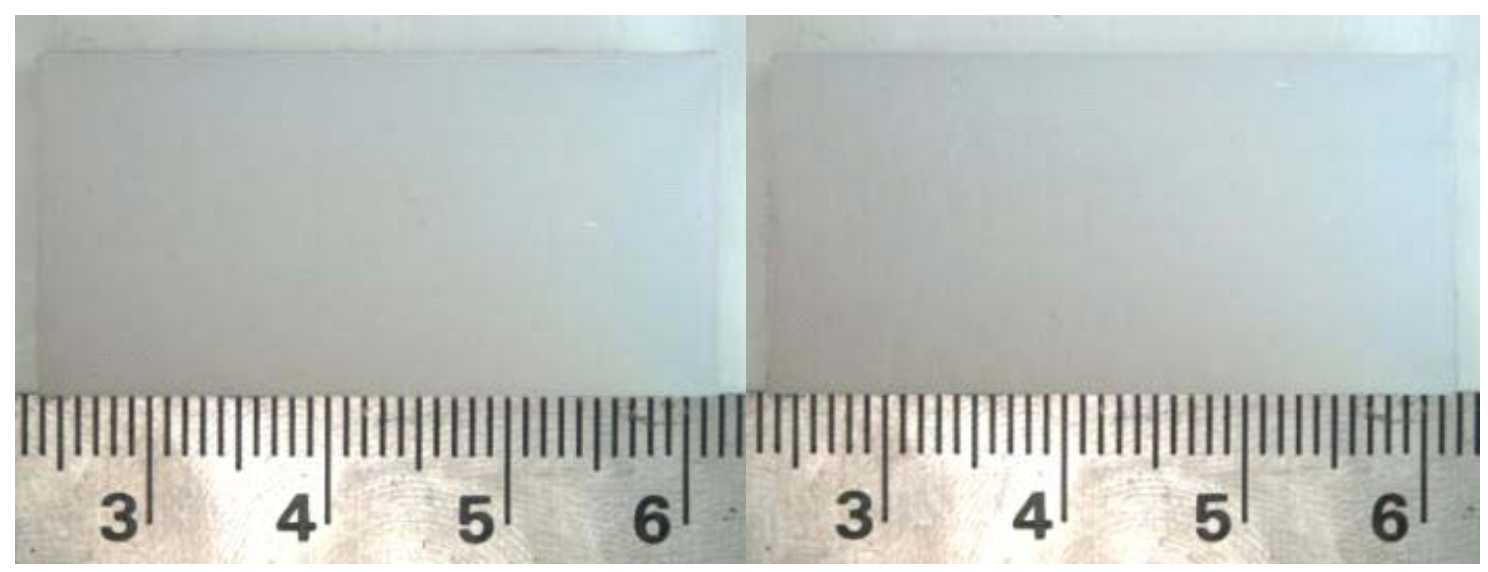

Left: FEP - $74 \% \mathrm{H}_{2} \mathrm{SO}_{4} 115^{\circ} \mathrm{C}\left(1^{\text {st }}\right.$ test)

Right: FEP - $80 \% \mathrm{H}_{2} \mathrm{SO}_{4} 150^{\circ} \mathrm{C}\left(1^{\mathrm{t}}\right.$ test)

Figure 4-14: Photographs of FEP from the High Acid Test Conditions. 


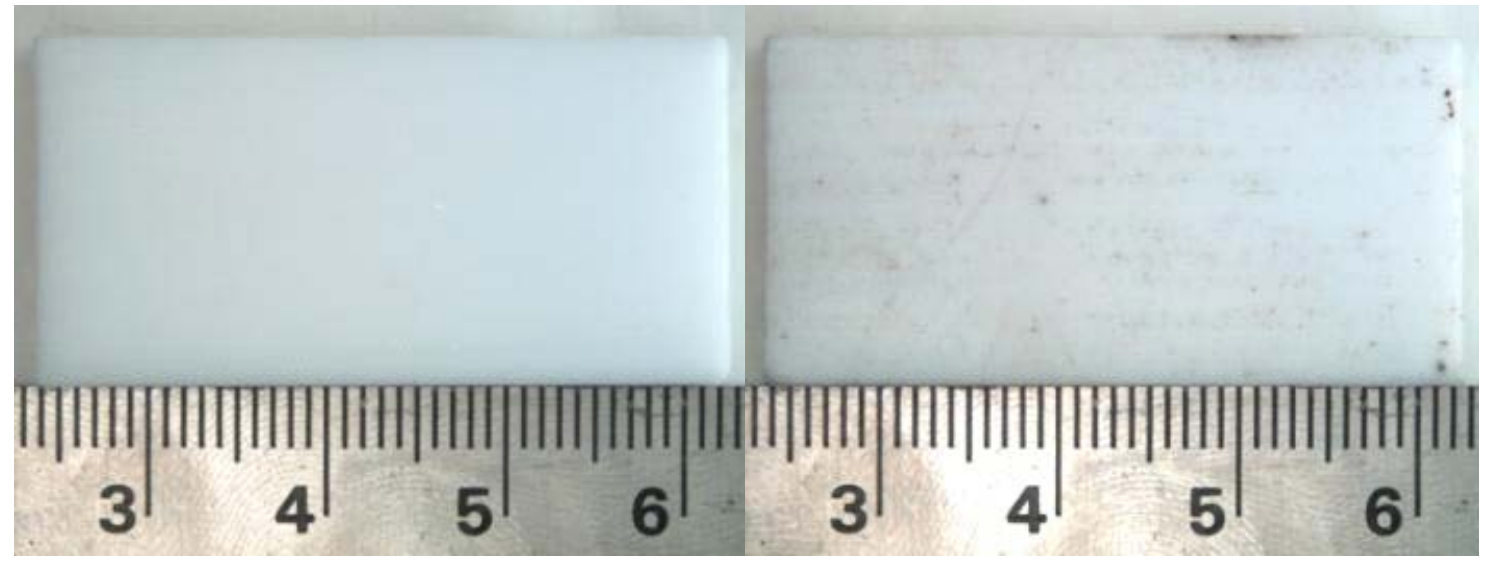

Left: PTFE - $65 \% \mathrm{H}_{2} \mathrm{SO}_{4} 50^{\circ} \mathrm{C}\left(1^{\text {st }}\right.$ test)

Right: PTFE - $70 \% \mathrm{H}_{2} \mathrm{SO}_{4} 85^{\circ} \mathrm{C}$ ( $1^{\text {st }}$ test)

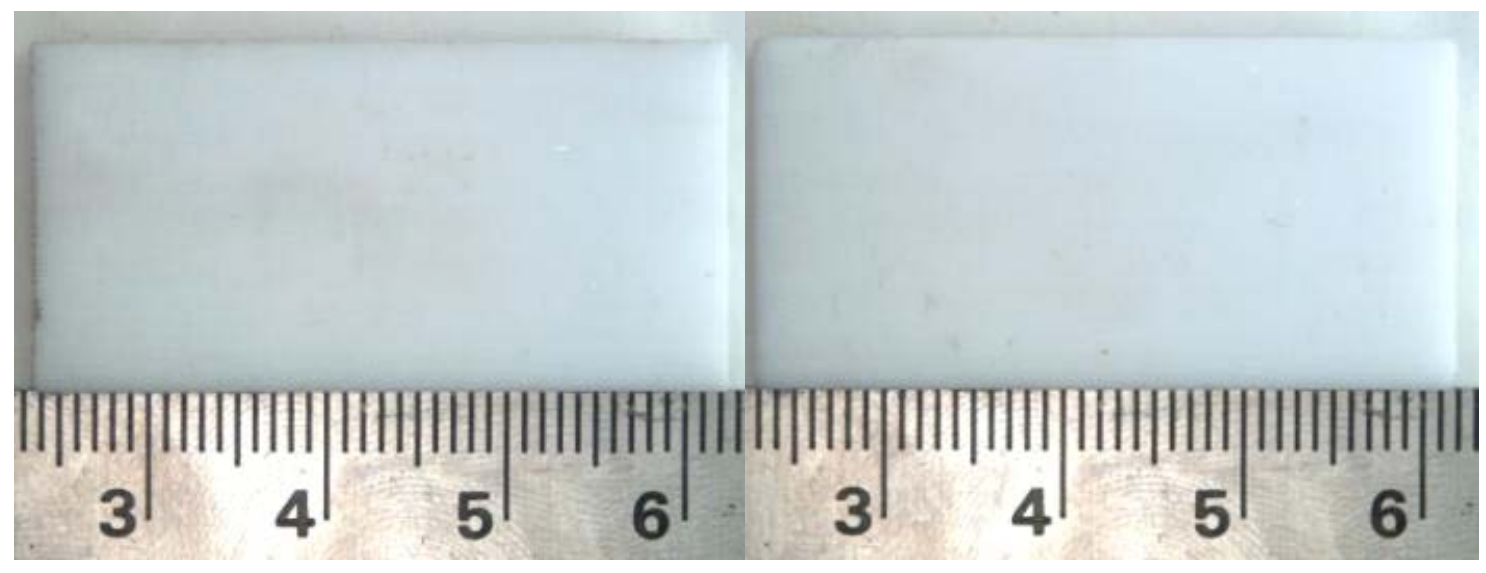

Left: PTFE - $74 \% \mathrm{H}_{2} \mathrm{SO}_{4} 115^{\circ} \mathrm{C}\left(1^{\text {t }}\right.$ test) Right: PTFE - $80 \% \mathrm{H}_{2} \mathrm{SO}_{4} 150^{\circ} \mathrm{C}$ (1 $1^{\text {st }}$ test)

Figure 4-15: Photographs of PTFE From the High Acid Test Conditions. 


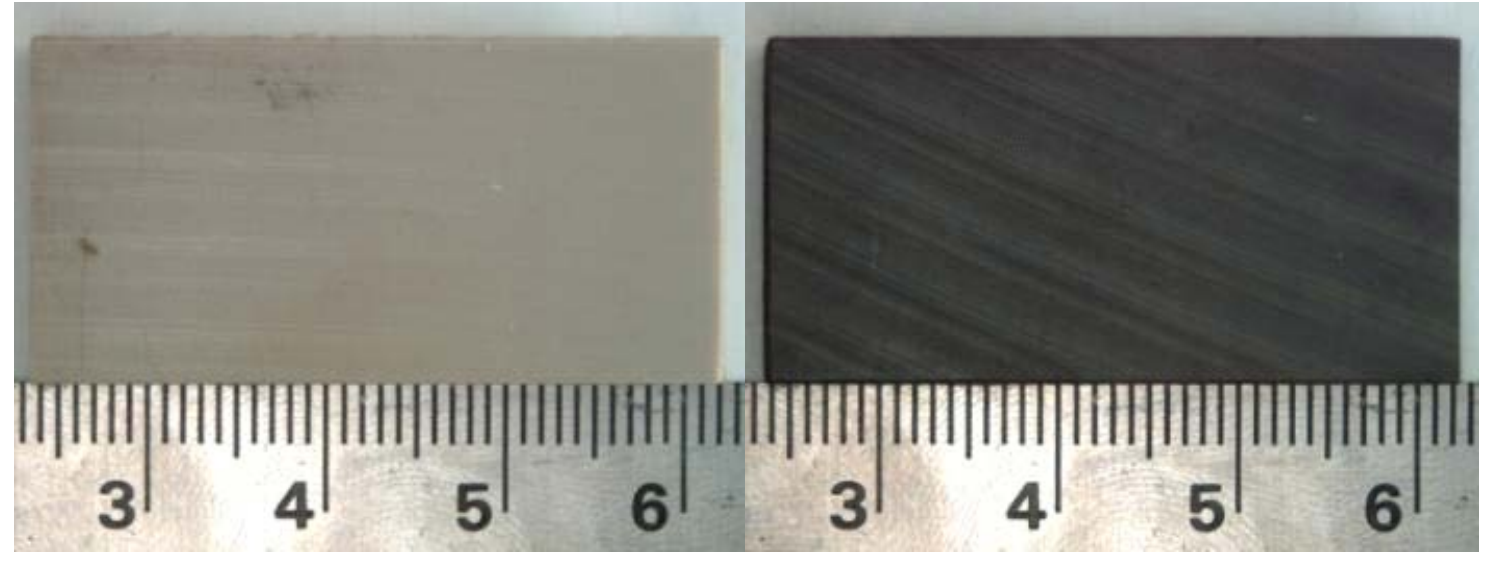

Left: PEEK - $65 \% \mathrm{H}_{2} \mathrm{SO}_{4} 50^{\circ} \mathrm{C}$ ( $1^{\text {st }}$ test)

Right: PEEK - $70 \% \mathrm{H}_{2} \mathrm{SO}_{4} 85^{\circ} \mathrm{C}$ ( $1^{\text {st }}$ test)

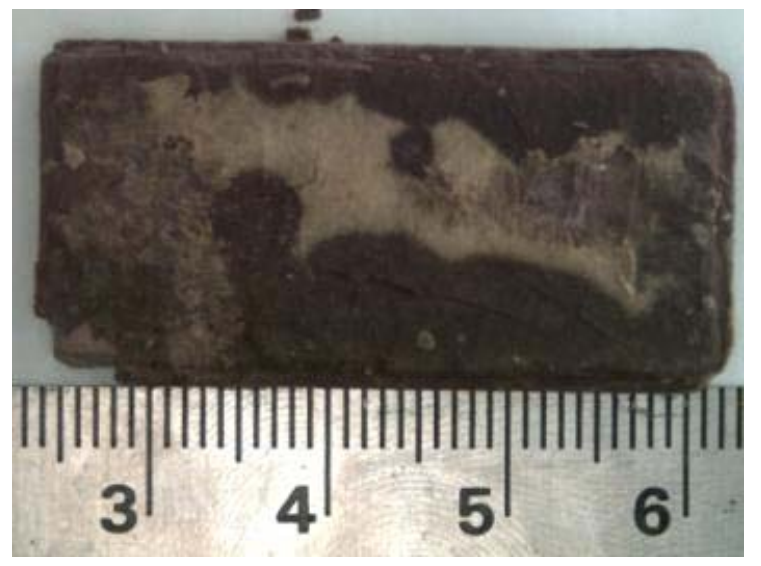

Left: PEEK - $74 \% \mathrm{H}_{2} \mathrm{SO}_{4} 115^{\circ} \mathrm{C}$ ( $1^{\text {\$t }}$ test)

Figure 4-16: Photographs of PEEK From the High Acid Test Conditions. 


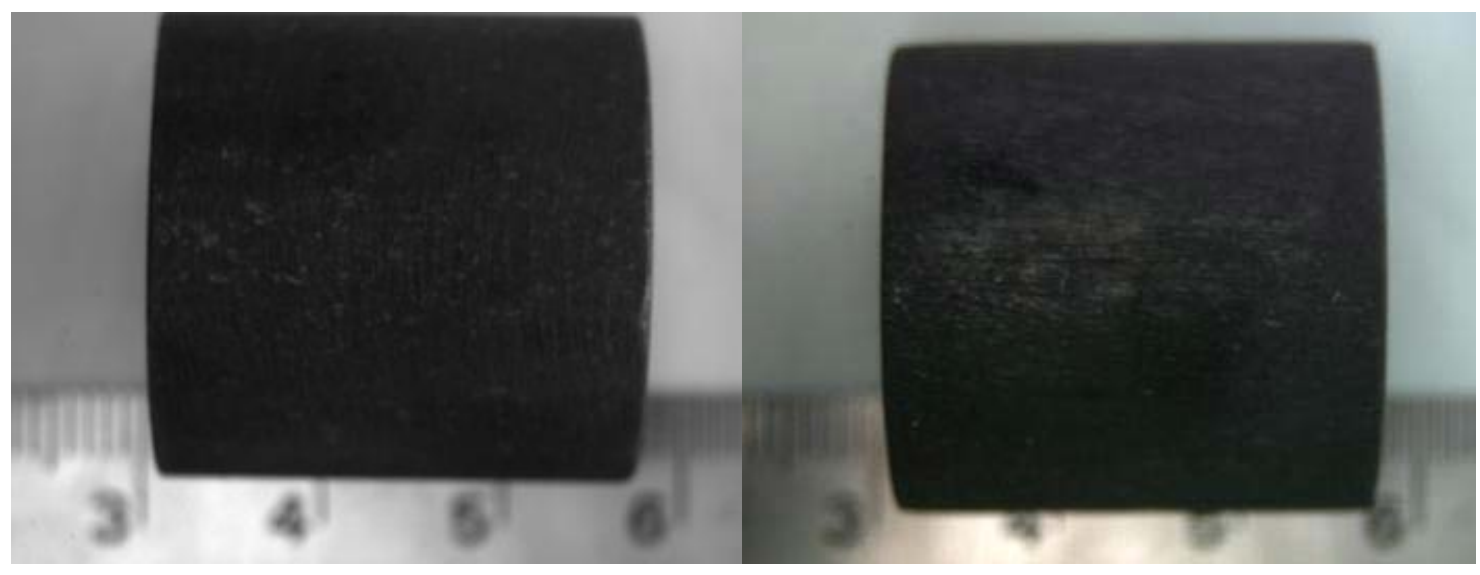

Left: Graphite - $65 \% \mathrm{H}_{2} \mathrm{SO}_{4} 50^{\circ} \mathrm{C}\left(1^{\text {st }}\right.$ test)

Right: Graphite $-70 \% \mathrm{H}_{2} \mathrm{SO}_{4} 85^{\circ} \mathrm{C}\left(1^{\text {st }}\right.$ test $)$

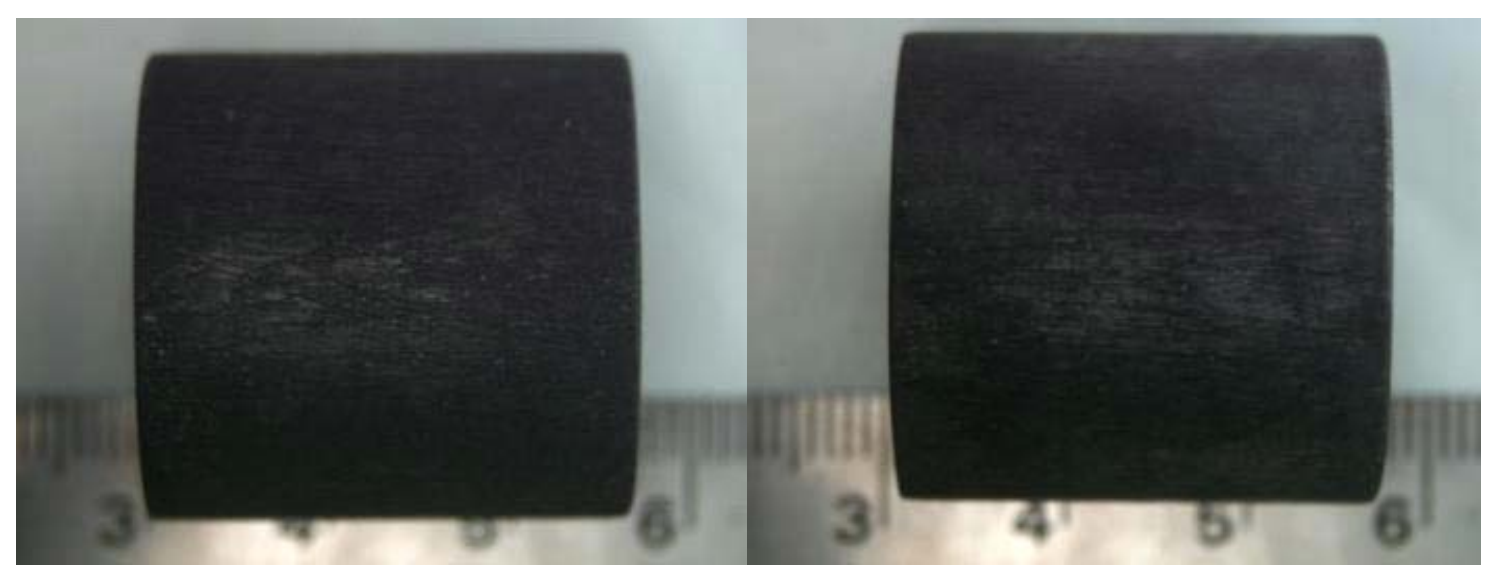

Left: Graphite - $74 \% \mathrm{H}_{2} \mathrm{SO}_{4} 115^{\circ} \mathrm{C}\left(1^{\text {st }}\right.$ test)

Right: Graphite $-80 \% \mathrm{H}_{2} \mathrm{SO}_{4} 150^{\circ} \mathrm{C}$ ( $1^{\text {st }}$ test)

Figure 4-17: Photographs of Graphite From the High Acid Test Conditions. 


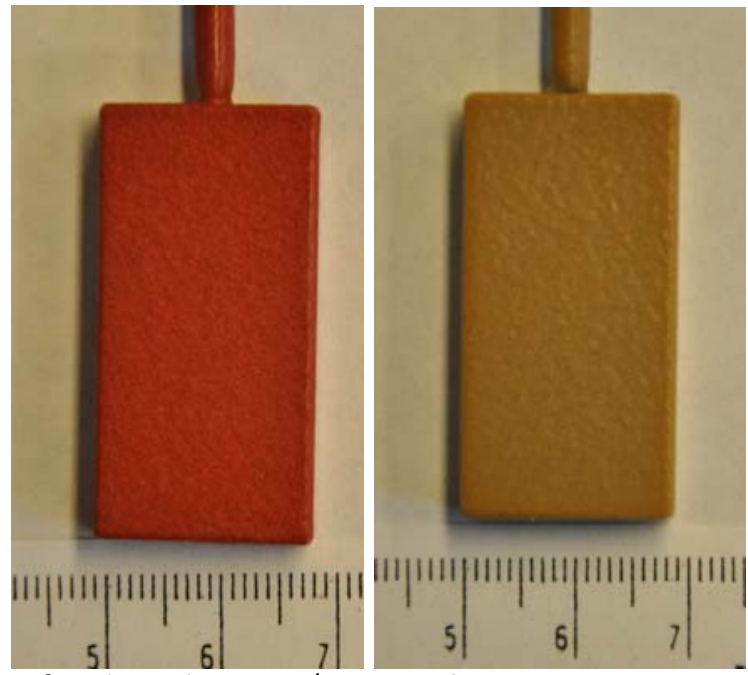

Left: Ruby Red $-375 \mathrm{mg} / \mathrm{L} \mathrm{H}_{2} \mathrm{SO}_{4} 54 ? \mathrm{C}$

Right: MP501 - 375mg/L $\mathrm{H}_{2} \mathrm{SO}_{4} 54$ ?C

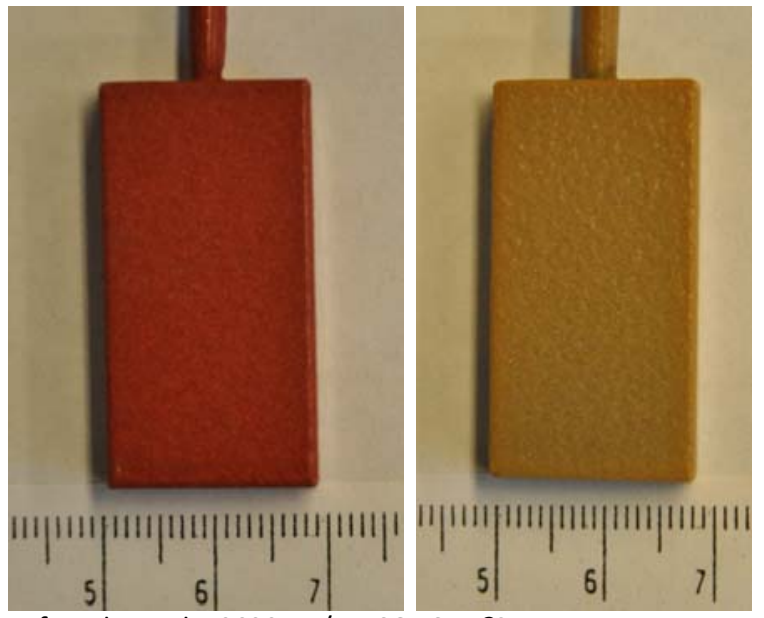

Left: Ruby Red $-2000 \mathrm{mg} / \mathrm{L} \mathrm{H}_{2} \mathrm{SO}_{4} 65.5$ ?

Right: MP501 - 2000mg/ $\mathrm{LH}_{2} \mathrm{SO}_{4}$ 65.5?

Figure 4-18: Photographs of Teflon Coated Samples From the Low Acid Concentration Test Conditions. 

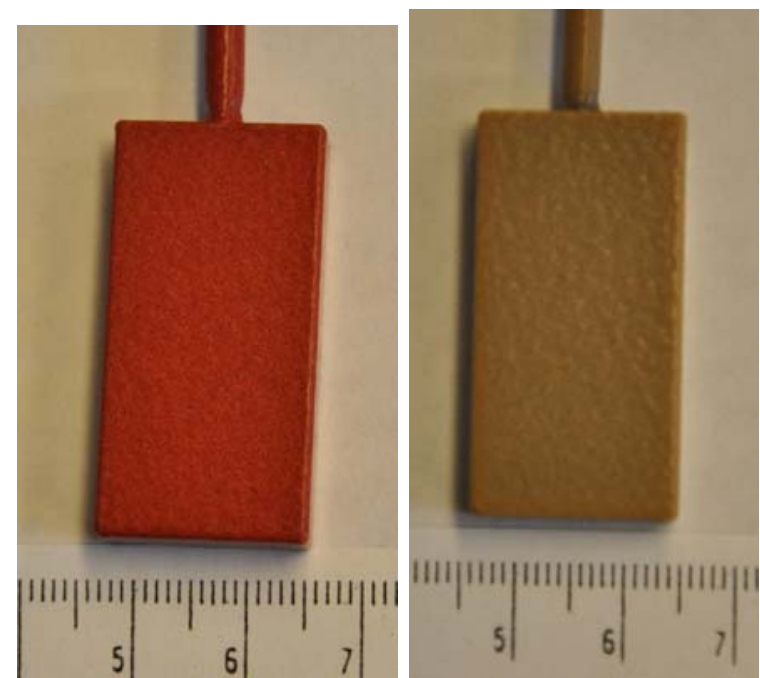

Left: Ruby Red - $65 \% \mathrm{H}_{2} \mathrm{SO}_{4} 50$ ?

Right: MP501 - 65\% $\mathrm{H}_{2} \mathrm{SO}_{4} 50$ ?

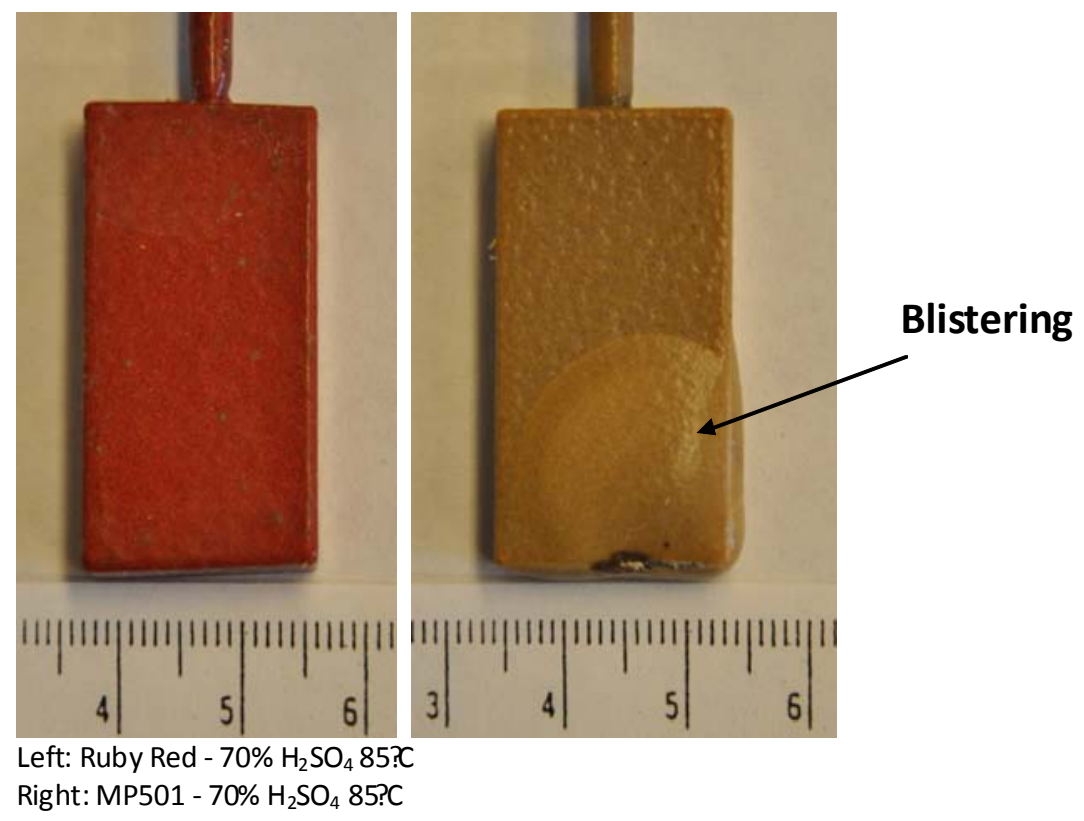

Figure 4-19: Photographs of Teflon Coated Samples From the High Acid Concentration Test Conditions. 


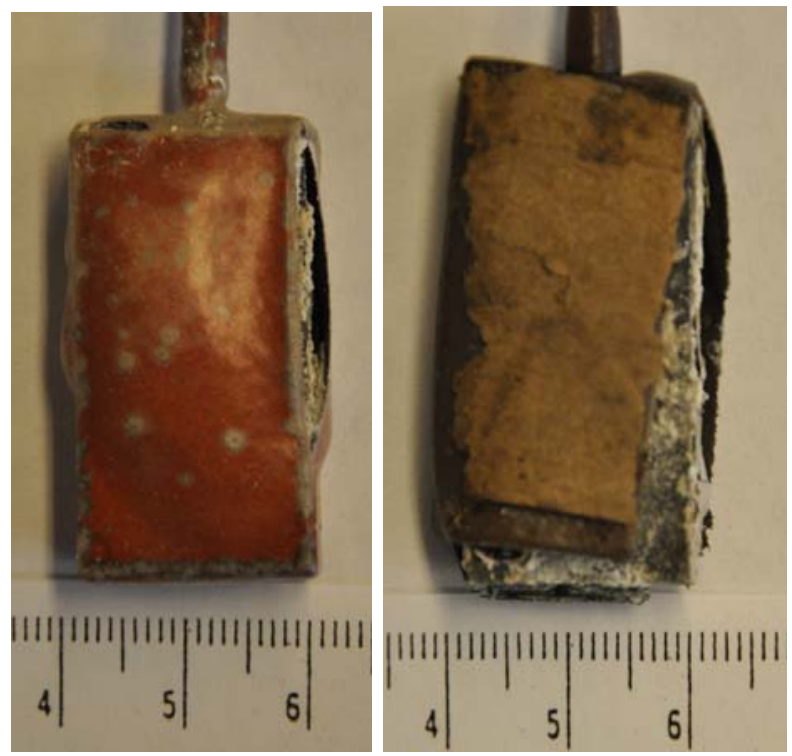

Left: Ruby Red - $80 \% \mathrm{H}_{2} \mathrm{SO}_{4} 150$ ?

Right: MP501 - 80\% $\mathrm{H}_{2} \mathrm{SO}_{4} 150$ ?C

Figure 4-19 (continued): Photographs of Teflon Coated Samples From the High Acid Concentration Test Conditions.

Assuming the corrosion reaction is thermally activated, the corrosion rate should depend on temperature by an Arrhenius equation of the form

$$
C R=A \cdot \exp (-B / R T)
$$

In equation (1), CR is the corrosion rate, $A$ is a pre-exponential term, $B$ is a measure of the activation energy for the corrosion reaction, $R$ is the gas constant $(8.31 \mathrm{~J} /(\mathrm{mol} \cdot \mathrm{K})$ ), and $T$ is absolute temperature. In these tests, it must be noted that both temperature and acid concentration were increased simultaneously in order to simulate the service conditions of the heat exchanger. Thus, $B$ reflects the effect of both temperature and acid concentration, and the analysis must therefore be considered only semiquantitative. Equation (1) indicates that a plot of $\ln (C R)$ vs. 1/T should produce a linear fit in which the intercept is $\ln (A)$ and the slope is $-B / R$. Figures 4-20 through 4-23 show these plots. The values of $\ln (A)$ and $B$ are summarized for each condition in Table 4-6 along with the $R^{2}$ value for each linear fit to the data. Note that the $R^{2}$ values are generally high, suggesting equation (1) provides a good representation of the corrosion rate data. 


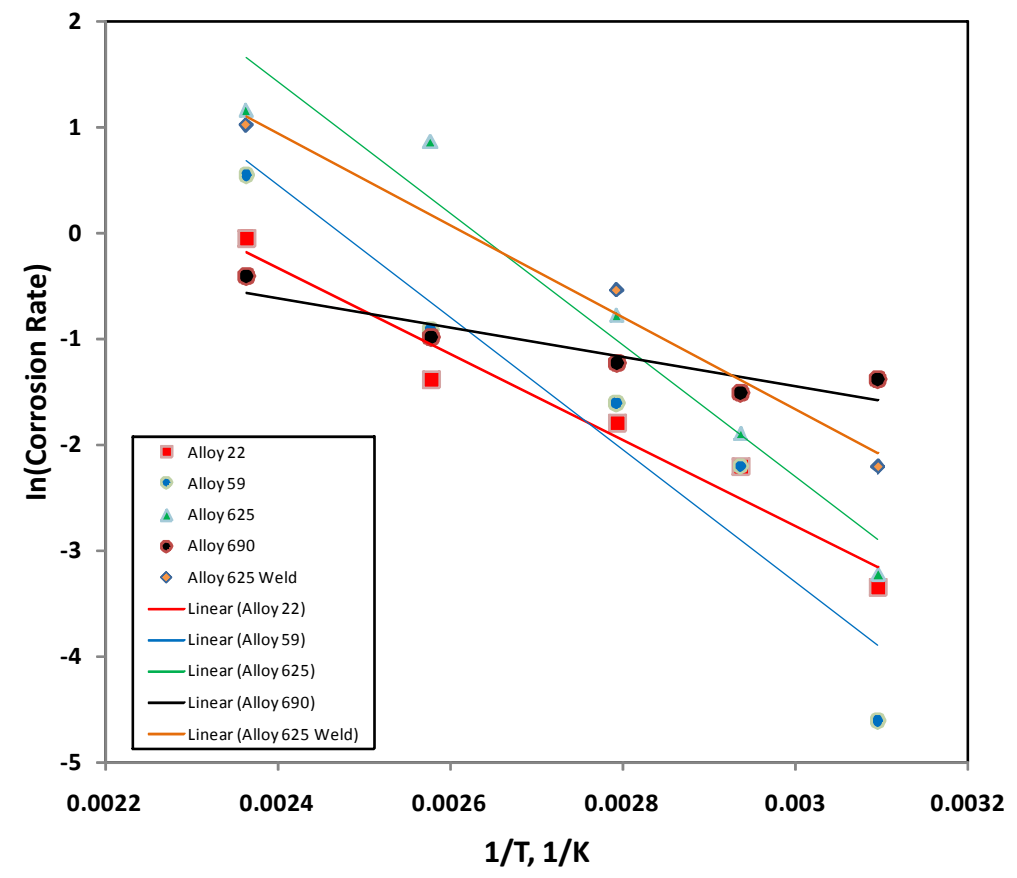

Figure 4-20: Arrhenius Plot of $\operatorname{In}$ (Corrosion Rate) as a Function of 1/T for the Nickel Alloys in the High Acid Concentration Tests.

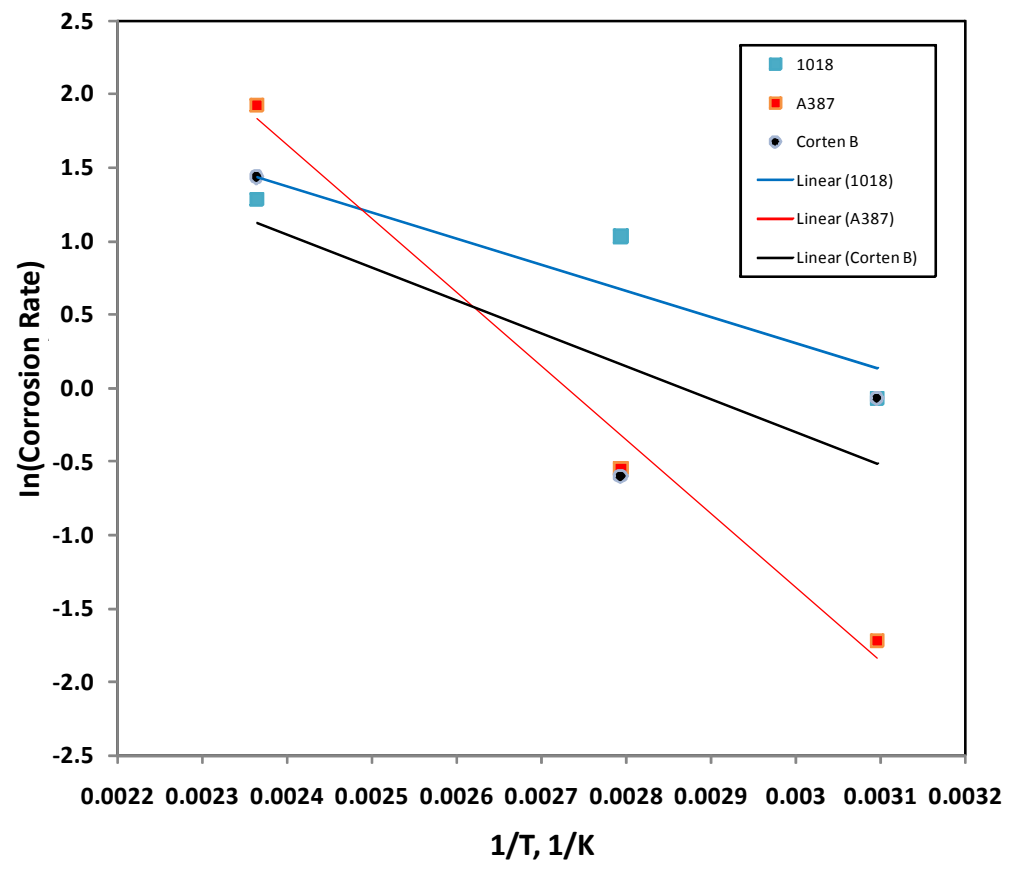

Figure 4-21: Arrhenius Plot of $\ln$ (Corrosion Rate) as a Function of $1 / \mathrm{T}$ for the Steels in the High Acid Concentration Tests. 


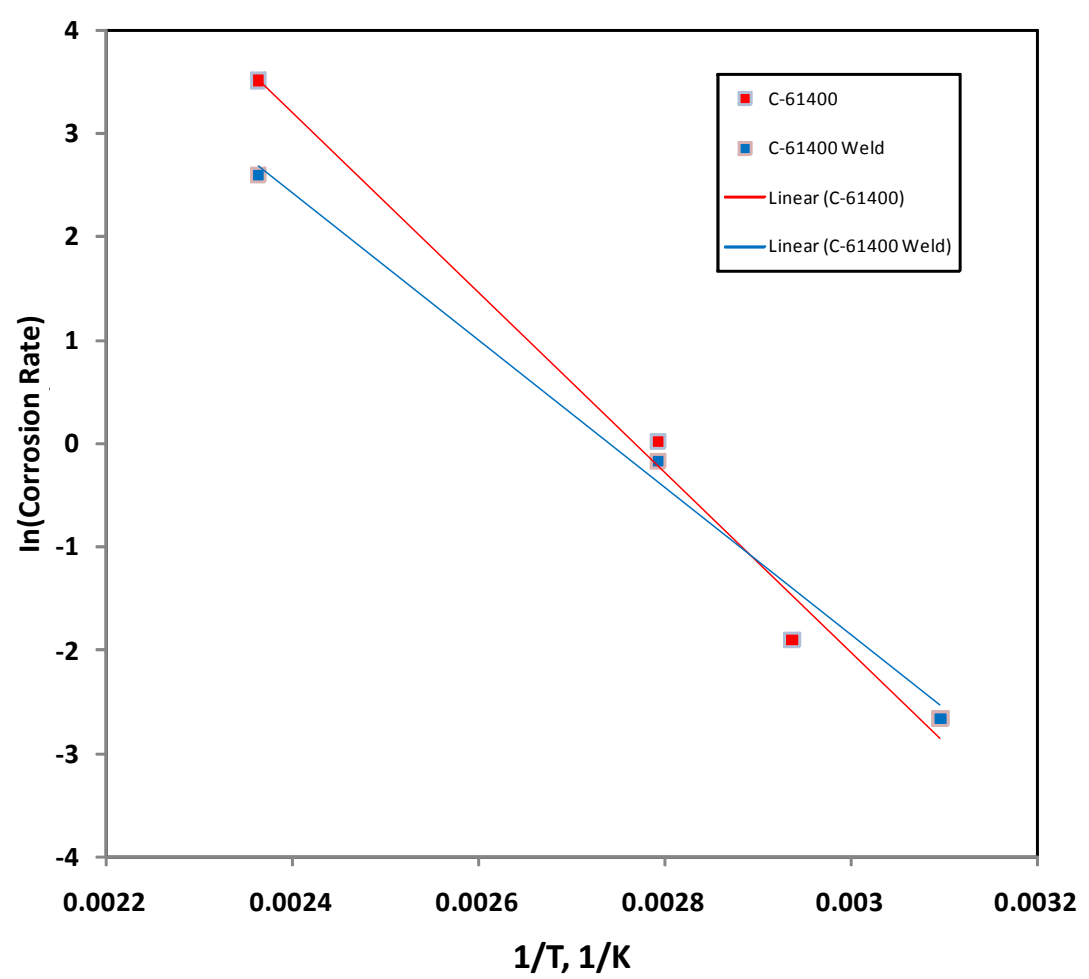

Figure 4-22: Arrhenius Plot of $\ln$ (Corrosion Rate) as a Function of $1 / \mathrm{T}$ for the Aluminum Bronze Alloy in the High Acid Concentration Tests.

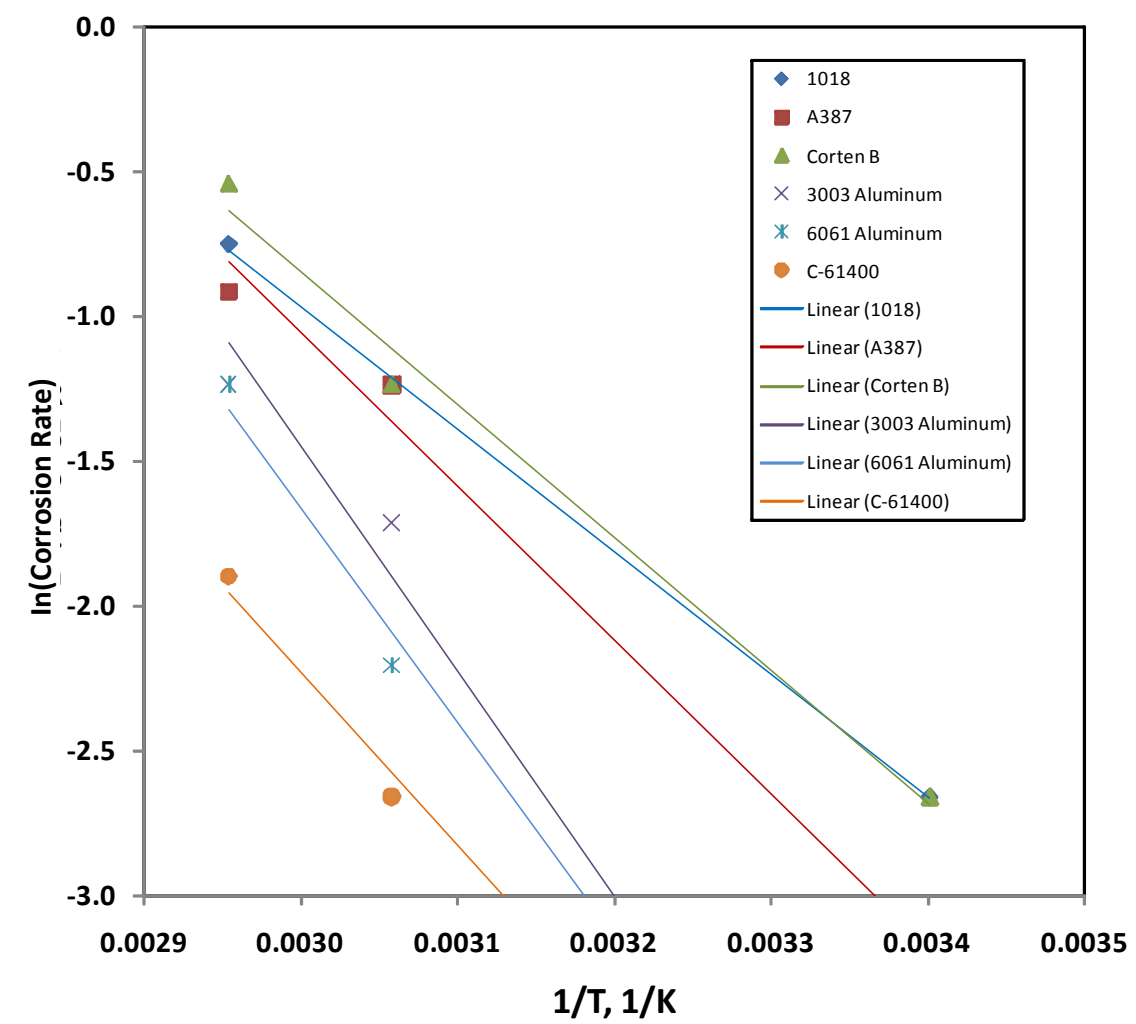

Figure 4-23: Arrhenius Plot of $\operatorname{In}$ (Corrosion Rate) as a Function of $1 / T$ for the Steels, Aluminum Alloys, and Aluminum Bronze Alloy in the Low Acid Concentration Tests. 
Table 4-6: Summary of In (A), B, and $R^{2}$ Values From Arrhenius Plots Provided in Figures 4-18 through 4-21.

\begin{tabular}{|c|c|c|c|}
\hline Alloy & $\operatorname{Ln}(A)$ & $\mathrm{B}, \mathrm{J} / \mathrm{mol}$ & $\mathrm{R}^{2}$ \\
\hline \multicolumn{4}{|c|}{ High Acid Conditions } \\
\hline 1018 Steel & 5.61 & 14,700 & 0.81 \\
\hline A387 Steel & 13.7 & 41,740 & 0.99 \\
\hline Corten B Steel & 6.42 & 18,620 & 0.61 \\
\hline Alloy 22 & 9.42 & 33,740 & 0.95 \\
\hline Alloy 59 & 15.5 & 51,980 & 0.91 \\
\hline Alloy 625 & 16.4 & 51,660 & 0.95 \\
\hline Alloy 625 Welded & 11.4 & 36,090 & 0.99 \\
\hline Alloy 690 & 2.71 & 11,520 & 0.86 \\
\hline C-61400 & 24.1 & 72,370 & 0.99 \\
\hline C-61400 Welded & 19.5 & 59,280 & 0.99 \\
\hline \multicolumn{4}{|c|}{ Low Acid Conditions } \\
\hline 1018 Steel & 11.7 & 35,160 & 0.99 \\
\hline A387 Steel & 14.9 & 44,100 & 0.99 \\
\hline Corten B Steel & 12.9 & 38,100 & 0.99 \\
\hline 3003 Aluminum & 21.8 & 64,460 & 0.99 \\
\hline 6061 Aluminum & 20.5 & 61,470 & 0.99 \\
\hline C-61400 & 15.7 & 49,540 & 0.99 \\
\hline
\end{tabular}

The plots for the nickel alloys (Figure 4-20) show that all alloys except 690 have similar slopes. This difference is probably associated with differences in composition among the alloys. Alloys 22, 59, and 625 are all Ni-Cr-Mo alloys with similar chromium levels while alloy 690 is essentially a Ni-Cr-Fe alloy with no molybdenum and higher chromium. (See Table A in the Appendix for alloy compositions.) Molybdenum is an important alloying element for stabilizing the passive film in aggressive aqueous solutions. The corrosion rates of the Mo-bearing alloys are lower than that of alloy 690 at the lower temperatures, thus leading to the higher B values in Table 4-6. The corrosion rate of alloy 690 exhibits less dependence on temperature and shows lower corrosion rates at the two most aggressive test conditions, which may be attributed to the higher chromium content of the alloy. It is difficult to draw any similar correlations with the data for the steels. It should be noted that the carbon and low alloy steels are known to exhibit a decrease in corrosion rate with increasing acid concentration within the range of 60 to 70 percent $\mathrm{H}_{2} \mathrm{SO}_{4}$. For example, Fontana [1] has demonstrated that the corrosion rate of steels can decrease by a factor of two at ambient temperature 
when the acid concentration is increased from 60 percent to 70 percent $\mathrm{H}_{2} \mathrm{SO}_{4}$. Thus, equation (1) may not provide an accurate representation for steels under these test conditions due to this effect. Note that two of the steel alloys have the lowest $R^{2}$ values in Table 4-6. At acid concentrations below approximately ten percent, previous results presented by Fontana [Ref. 1] have shown that the corrosion rate of steel increases with increasing acid concentration. This is consistent with the data in Table 4-6 for the low acid conditions in which the steels have similar $\ln (A)$ and $B$ values. Note that the $A l$ alloys also have similar $\ln (A)$ and $B$ values.

The results presented here can be compared to available data on similar materials and also provide useful information on newer alloys (e.g., alloys 22,690 , and 59) that can be used for material selection purposes. Previously published data [Ref. 2] have shown that carbon and low alloy steels (i.e., similar to the 1018, A387, and Corten $B$ alloys investigated in this work) are known to provide adequate corrosion protection in sulfuric acid near room temperature at acid concentrations above $\sim 70$ percent $\mathrm{H}_{2} \mathrm{SO}_{4}$. Data published on the corrosion rates of steels under these conditions are typically in the range of 0.1 to $0.5 \mathrm{~mm} / \mathrm{year}$ [Refs. 1 and 2]. Steels are rapidly attacked at lower acid concentrations and higher temperatures. Although acid concentrations above 70 percent $\mathrm{H}_{2} \mathrm{SO}_{4}$ are of interest for this application, the temperature is too high $\left(>115^{\circ} \mathrm{C}\right)$ for steels to provide adequate protection. Moderate corrosion rates were observed at the lower acid concentrations tested in this program, but the rate of 0.40 to 0.58 $\mathrm{mm} /$ year in the $2000 \mathrm{mg} / \mathrm{L}$ solution is too high to warrant the use of steels. Published data on stainless steels [Ref. 2] show that these alloys are generally able to maintain protective passive scales at temperatures below $40^{\circ} \mathrm{C}$ and acid concentrations below about 1 percent and above 93 percent $\mathrm{H}_{2} \mathrm{SO}_{4}$. The alloys will undergo active corrosion at intermediate acid concentrations and higher temperatures. This is consistent with the results from this program which exhibited very low corrosion rates at low acid/low temperature conditions and poor corrosion resistance at the high acid/high temperature conditions. Of the stainless steels investigated in this work for the high acid conditions, alloy AL6XN exhibited the lowest corrosion rate, which can be attributed to its high chromium content (20 to $22 \mathrm{wt}$ percent) and presence of molybdenum (6 to $7 \mathrm{wt}$ percent), each of which stabilize the protective surface scale. All of the remaining 
materials showed very low corrosion rates at the low acid conditions. There is little reported experience on the use of aluminum alloys for handling sulfuric acid, and the corrosion rates were observed to increase with increasing acid concentration and temperature. In contrast, the remaining materials showed negligible corrosion rates under all the low acid conditions, so it is difficult to justify the use of aluminum alloys for this application. Of the remaining alloys, conventional 304 stainless steel would be an optimum choice for the low acid conditions. This alloy is less expensive than the nickel alloys, showed negligible corrosion rates over the entire solution composition range, is readily available and easy to fabricate by conventional manufacturing methods.

The two Teflon coatings tested do not appear to be candidate materials for this application. While only a moderate weight gain was observed for the $375 \mathrm{mg} / \mathrm{L} \mathrm{H}_{2} \mathrm{SO}_{4}$ solution, this may be evidence of solution permeation through the coating that can lead to subsequent corrosion of the underlying substrate. In addition, the weight loss rate for the $2000 \mathrm{mg} / \mathrm{L} \mathrm{H}_{2} \mathrm{SO}_{4}$ was significant, which may be a sign of the coating leaching into the solution under this more aggressive condition. The coatings also showed evidence of permeation and failure under the high acid test conditions.

Corrosion data published to date indicate that nickel alloys, the polymer materials, and graphite are all known to exhibit good resistance to sulfuric acid [Refs. 1 and 2]. However, the results shown here indicate there are important differences among the materials considered for the conditions of interest to this application. Alloy 625 is often used to handle sulfuric acid. Data from Reference 2 indicate this alloy exhibits corrosion rates below $0.5 \mathrm{~mm} /$ year at temperatures below $\sim 85^{\circ} \mathrm{C}$ and acid concentrations from 0 to 70 percent $\mathrm{H}_{2} \mathrm{SO}_{4}$. The corrosion rates become appreciable above these ranges. This is consistent with the corrosion rate data shown in Table 4-4 from this work. Thus, this alloy is not preferred for this application. In contrast, results from this work show that alloys 22, 59, and 690 exhibited lower corrosion rates over a wider range of acid concentrations and temperatures. Alloys 22 and 59 are known to be among the best alloys for resistance to aggressive aqueous corrosion. The good corrosion resistance of these alloys is attributed to their high chromium content (20 - 24 wt percent) and high molybdenum concentration (12 to $16.5 \mathrm{wt}$ percent). The good 
performance of alloy 690 is probably a result of its high chromium content (27-31 wt percent). Of these materials, alloys 22 and 690 are preferred because they showed the lowest susceptibility to accelerated corrosion at the higher temperatures. Alloy 22 showed the best overall performance and is the preferred material for the high acid conditions. This alloy is readily available and can be manufactured by conventional manufacturing methods. The polymer materials are potential options for this application as either protective coatings or structural materials. Of the three materials evaluated here, the FEP and PTFE performed the best. PTFE has been reported to be free from attack of $\mathrm{H}_{2} \mathrm{SO}_{4}$ over the entire composition range at temperature up to $260^{\circ} \mathrm{C}$ [Ref. 2], which is consistent with the results presented here. The ultimate use of FEP and/or PTFE as a structural material or coating would have to be justified by also considering factors associated with reduced heat transfer (due to lower thermal conductivity), ability to handle operating stresses (due to reduced strength), and possible increased assembly costs (due to difficulty in manufacturing relative to engineering alloys).

\section{Conclusions}

The corrosion behavior of a wide range of materials was evaluated under low and high acid sulfuric acid conditions that are representative of the heat exchanger conditions. The following conclusions can be drawn from the results:

1. The corrosion rates of the engineering alloys increased with increasing acid concentration and temperature. Except for the steels, the corrosion rate of the engineering alloys followed an equation of the form $C R=A \cdot \exp (-B / R T)$.

2. All materials except steels showed acceptable corrosion rates in the low acid conditions. Of the remaining alloys, 304 stainless steel is the preferred choice for the low acid condition due to the relatively low cost, ease of fabrication, and negligible corrosion rates over the entire range of test conditions.

3. Teflon coatings MP501 and Ruby Red are not likely candidates for this application due to evidence of permeation, leaching of the coating, and complete coating failure under the most aggressive test conditions. 
4. Alloys 22 and 690 along with polymeric materials FEP and PTFE showed the best performance in the high acid conditions. The polymer materials showed no significant signs of degradation over the entire acid composition range. Alloys 22 and 690 exhibited increased corrosion rates with increasing acid concentration and temperature, but should provide acceptable performance up to 74 percent $\mathrm{H}_{2} \mathrm{SO}_{4}$ and $115^{\circ} \mathrm{C}$ where the corrosion rates are less than $0.4 \mathrm{~mm} /$ year.

5. The corrosion rates of alloys 22 and 625 that contained welds were not significantly different than the wrought alloys.

6. Alloy 22 is the preferred alloy for the high acid concentration due to its low corrosion rate, availability, and ability to be readily fabricated.

\section{References}

1. S.K. Brubaker, Corrosion by Sulfuric Acid, ASM Handbook, Volume 13, Corrosion, ASM International, Materials Park, OH, 2001, pp. 1148-1154.

2. M.G. Fontana, Corrosion Engineering, McGraw-Hill Publishing, New York, NY, 1986, pp. 317-337. 


\section{CHAPTER 5}

\section{REDUCING SULFURIC ACID DEPOSITION ON HEAT EXCHANGER TUBES: MEASUREMENT OF ACID TRAP EFFECTIVENESS}

\section{Introduction}

Project DE-NT0005648 was undertaken with the knowledge that sulfuric acid corrosion of heat exchanger tubes could be a limiting factor in the cost effectiveness of using condensing heat exchangers to recover thermal energy and condensed water vapor from boiler flue gas. One of the project tasks involved tests to assess the potential of reducing the flue gas acid concentration entering the heat exchangers through use of additional surface area in the inlet region to capture a portion of the inlet $\mathrm{H}_{2} \mathrm{SO}_{4}$. The concept involved use of a section of inlet duct filled with closely spaced vertical flat plates aligned parallel to the flow direction (referred to as "acid traps" in this report). Tests were carried out with acid traps located upstream of the first heat exchanger (HX1), between $\mathrm{HX1}$ and $\mathrm{HX} 2$, and both upstream and downstream of $\mathrm{HX1}$.

\section{Results of Slip Stream Tests}

Tests to measure the effectiveness of acid traps in reducing flue gas sulfuric acid concentration were performed in slip streams of flue gas extracted from a gas-fired boiler and two coal-fired boilers. The results are described in the following sections.

Flue Gas from Gas-Fired Boiler. Tests were carried out at Lehigh University's Boiler House using a slip stream of flue gas from a natural gas-fired boiler. Controlled amounts of $\mathrm{H}_{2} \mathrm{SO}_{4}$ were injected into the flue gas slip stream upstream of the condensing heat exchanger apparatus to simulate the $\mathrm{H}_{2} \mathrm{SO}_{4}$ vapor aspects of the flue gas environment in a coal fired boiler.

The plan for this group of tests required that sulfuric acid condense on the first heat exchanger and in the acid trap, while the tube wall surfaces of this heat exchanger and acid trap were at temperatures above the water vapor dew point. The tube wall surfaces of most of the remaining heat exchangers were to be at temperatures below 
the water vapor dew point, leading to condensation of water vapor and sulfuric acid and the formation of relatively dilute acid-water solutions on the downstream heat exchangers. Figure 5-1 shows the physical arrangement of the heat exchangers and the acid trap and Table 5-1 gives the corresponding surface areas.

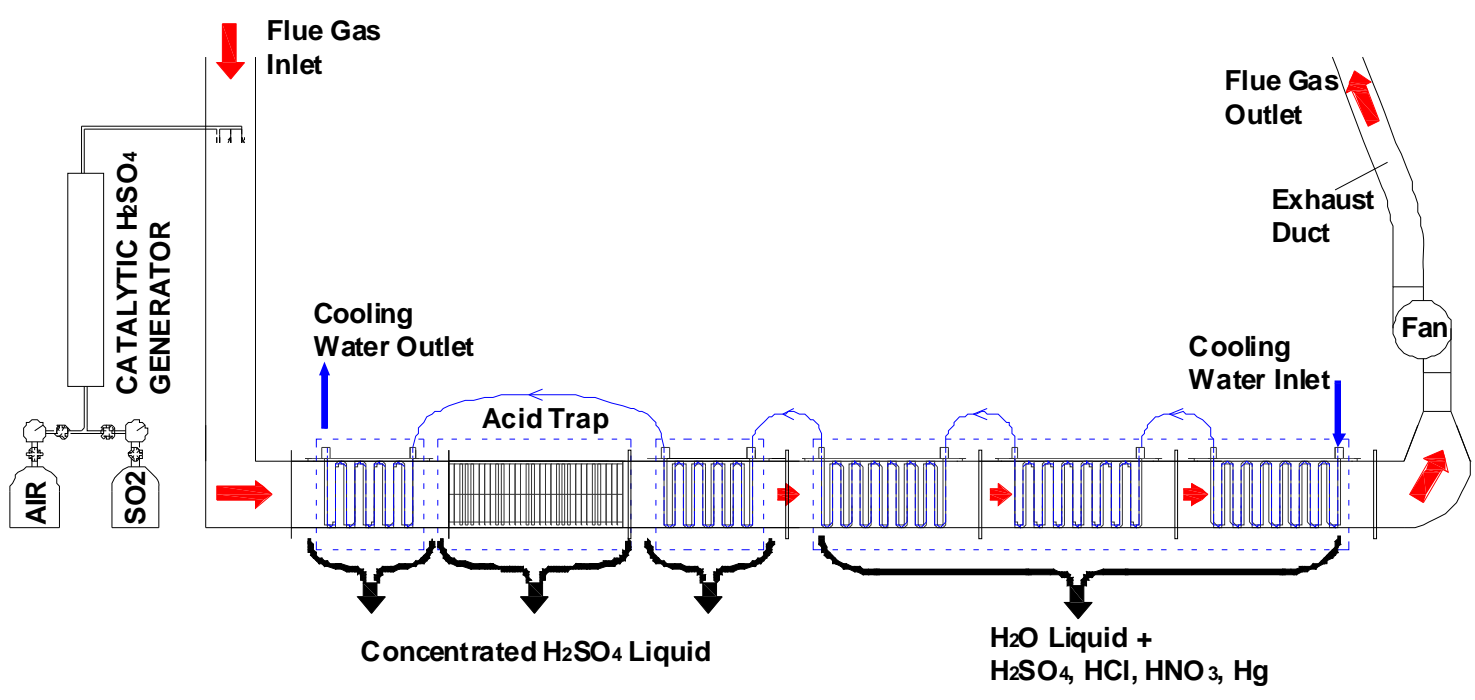

Figure 5-1: Diagram of Heat Exchanger Arrangement Used for Tests at Natural Gas-Fired Boiler

Table 5-1: Surface Areas of Heat Exchangers and Acid Trap

\begin{tabular}{|c|c|}
\hline Heat Exchanger & $\begin{array}{c}\text { Surface Area } \\
{\left[\mathrm{ft}^{2}\right]}\end{array}$ \\
\hline 1 & 7.5 \\
\hline Acid Trap & 66.0 \\
\hline 2 & 17.5 \\
\hline 3 & 12.5 \\
\hline 4 & 17.5 \\
\hline 5 & 17.5 \\
\hline
\end{tabular}

Seven tests were performed with the physical arrangement shown in Figure 5-1. Sulfur trioxide $\left(\mathrm{SO}_{3}\right)$, formed in a catalytic reactor, was injected into the flue gas upstream of the first heat exchanger to simulate flue gas from a coal-fired boiler. Once in contact with flue gas, the $\mathrm{SO}_{3}$ reacted with $\mathrm{H}_{2} \mathrm{O}$ vapor to form $\mathrm{H}_{2} \mathrm{SO}_{4}$ vapor. In some tests, duct heaters located upstream of the acid injection location preheated the flue gas to temperatures above the sulfuric acid dew point, thus preventing acid condensation upstream of the inlet of the first heat exchanger. 
Thermocouples were used to measure flue gas and cooling water temperatures at the inlet and exit of each heat exchanger. At any given axial position in the heat exchanger, the local tube wall temperature was higher than the local bulk cooling water temperature. Results obtained from analyses and earlier tests in this project had shown that the tube wall temperatures were typically within five degrees Fahrenheit of the local bulk cooling water temperatures.

Values of flue gas and cooling water flow rates were based on rotameter readings for the cooling water and S-probe measurements in the flue gas. Flue gas acid concentrations were measured using the Controlled Condensation Method at the inlet and exit of the first heat exchanger and at the exit of the acid trap.

Table 5-2 shows the process conditions for the seven tests and Figures 5-2 to 54 show temperatures, a water vapor condensation profile and a flue gas moisture concentration profile for one of the tests. The trends in these graphs show that no measureable water condensation occurred within HX1. Water condensation began within $\mathrm{HX} 2$ and increased in rate as the flue gas came in contact with lower temperature tube walls further downstream.

The Controlled Condensation measurements of flue gas $\mathrm{SO}_{3}$ concentrations at the inlet and exit of the acid trap show an average $\mathrm{SO}_{3}$ reduction of 13.7 percent across the acid trap (Table 5-3).

Table 5-2: Process Conditions for Acid Deposition Tests

\begin{tabular}{|r|c|c|c|c|c|c|}
\hline Date & $\begin{array}{c}\text { Flue Gas Temp } \\
{\left[{ }^{\circ} \mathrm{F}\right]}\end{array}$ & $\begin{array}{c}\text { Water Temp } \\
{\left[{ }^{\circ} \mathrm{F}\right]}\end{array}$ & $\begin{array}{c}\text { Flue Gas Flow } \\
{[\mathrm{lbm} / \mathrm{hr}]}\end{array}$ & $\begin{array}{c}\text { Water Flow } \\
{[\mathrm{lbm} / \mathrm{hr}]}\end{array}$ & Moisture \% & $\begin{array}{c}\text { Acid Trap Temp } \\
{\left[{ }^{\circ} \mathrm{F}\right]}\end{array}$ \\
\hline 26-Mar & 361 & 109 & 234 & 275 & 12.3 & 209 \\
\hline 29-Mar & 343 & 98 & 321 & 275 & 11.6 & 236 \\
\hline $30-M a r$ & 370 & 106 & 297 & 370 & 12.2 & 226 \\
\hline $30-M a r$ & 376 & 107 & 335 & 275 & 12.2 & 245 \\
\hline $31-M a r$ & 388 & 104 & 314 & 275 & 11.8 & 244 \\
\hline 1-Apr & 374 & 103 & 325 & 275 & 11.2 & 239 \\
\hline 1-Apr & 316 & 118 & 219 & 275 & 12.6 & 203 \\
\hline
\end{tabular}




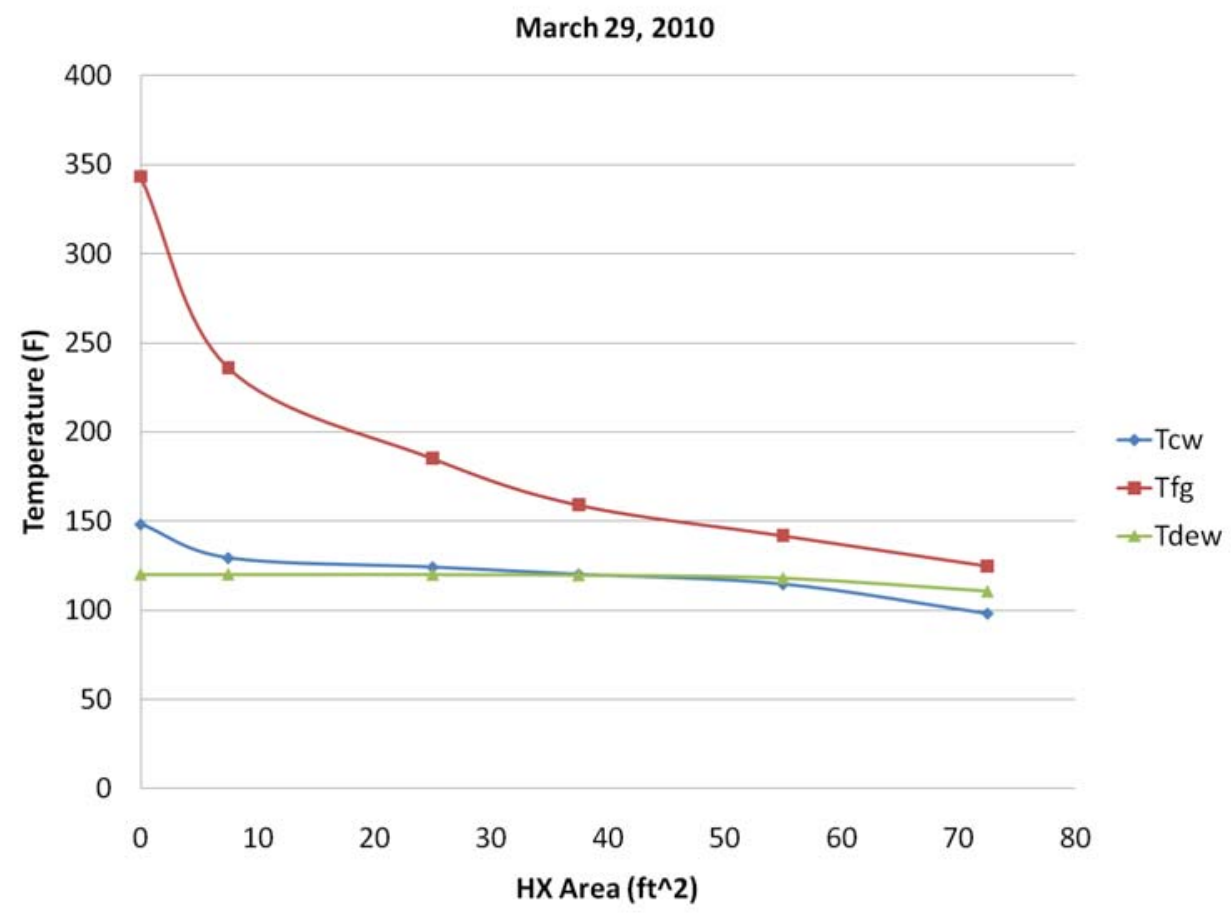

Figure 5-2: Flue Gas, Cooling Water, and Dew Point Temperature Distributions within Heat Exchanger Array

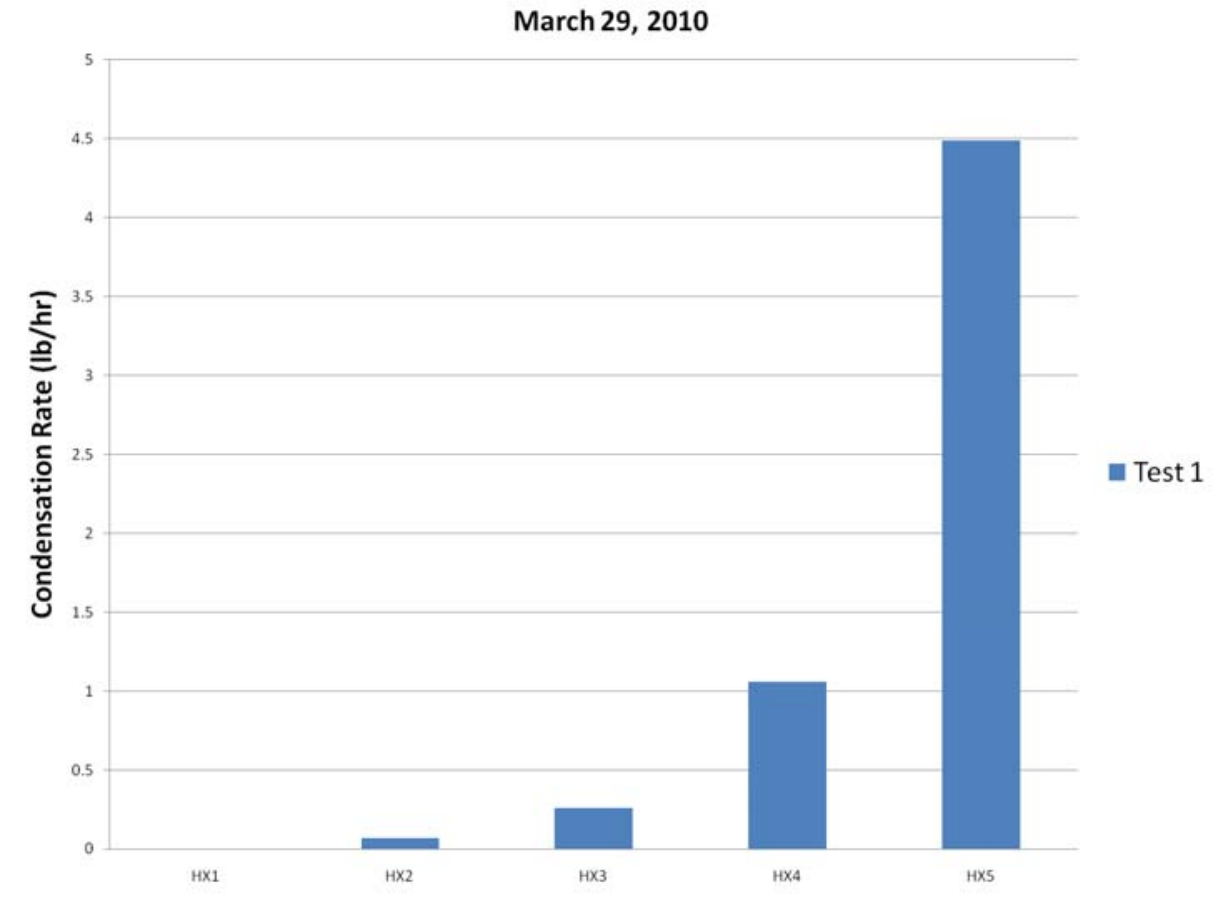

Figure 5-3: Measured Water Vapor Condensation Rates on the Five Heat Exchangers During Test 1 


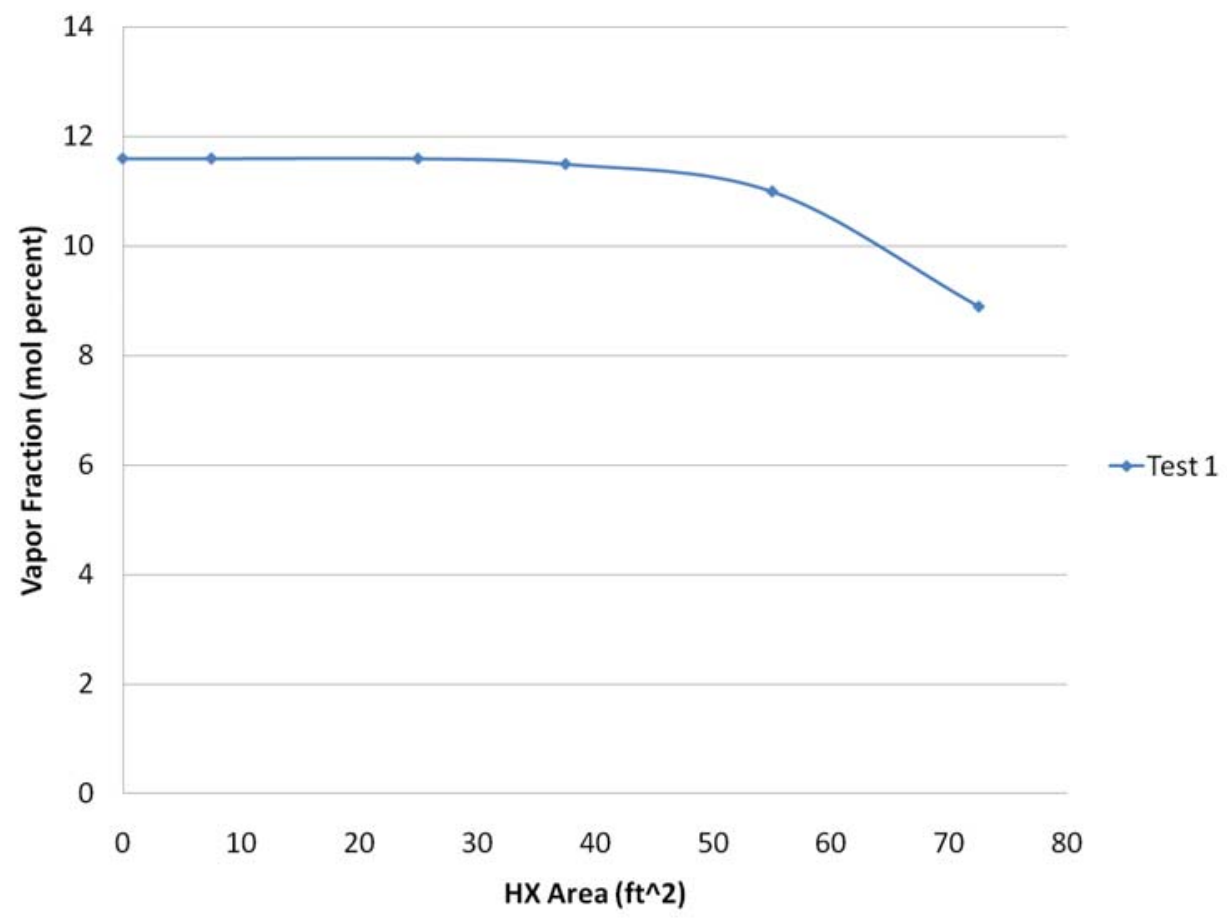

Figure 5-4: Predicted Flue Gas Water Vapor Mole Fraction Distribution within Heat Exchanger Array

Table 5-3: $\mathrm{SO}_{3}$ Capture Tests at Gas Fired Boiler with $\mathrm{SO}_{3}$ Injection

LEHIGH POWER HOUSE TESTS

\begin{tabular}{|c|c|c|c|}
\hline \multicolumn{3}{|c|}{ SO3 Concentration [ppm] } & \multirow[b]{2}{*}{ Reduction } \\
\hline Date & Trap Inlet & Trap Exit & \\
\hline $3 / 26 / 2010$ & 64 & 55 & $14.1 \%$ \\
\hline $3 / 29 / 2010$ & 25 & 18 & $28.0 \%$ \\
\hline 3/30/2010-a & 26 & 18 & $30.8 \%$ \\
\hline 3/30/2010-b & 30 & 28 & $6.7 \%$ \\
\hline $3 / 31 / 2010$ & 27 & 27 & $0.0 \%$ \\
\hline 4/1/2010-a & 29 & 26 & $10.3 \%$ \\
\hline 4/1/2010-b & 49 & 46 & $6.1 \%$ \\
\hline AVEF & GE REDU & ION: & $13.7 \%$ \\
\hline
\end{tabular}

Flue Gas from Unit B. The condensing heat exchanger apparatus tested at Unit B consisted of a long rectangular duct containing water-cooled heat exchangers connected in series. The apparatus processed a slip stream of flue gas from just upstream of the ID fan, and cooling water was supplied from the ash pond. There were five heat exchangers installed in the duct, with a total heat exchanger surface area of 
$72.5 \mathrm{ft}^{2}$ (Figure 5-5). In addition to the condensing heat exchangers, the apparatus contained $\mathrm{a} \mathrm{SO}_{3}$ trap which was installed between heat exchangers 1 and 2 .

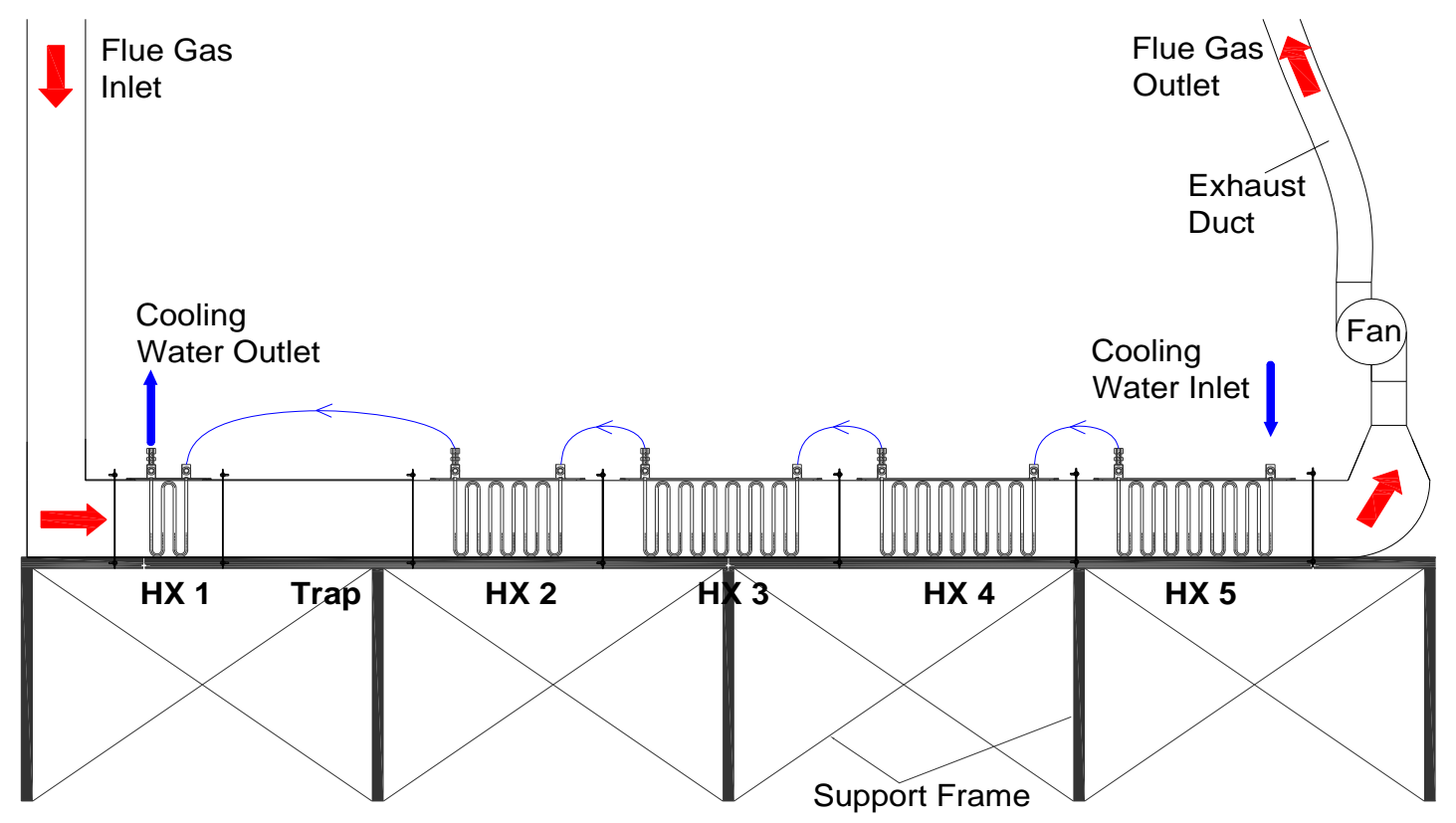

Figure 5-5: Arrangement of Heat Exchangers and Acid Trap

Each heat exchanger was instrumented to measure inlet and outlet temperatures of cooling water and flue gas, water condensation rate, and flue gas and water flow rates. During some tests, the Controlled Condensation Method was used to determine $\mathrm{H}_{2} \mathrm{SO}_{4}$ concentrations in the flue gas. Water condensate samples were collected and then analyzed using ion chromatography to determine the concentrations of sulfate, nitrate, and chloride.

The power plant burns a low sulfur PRB coal and the average measured $\mathrm{SO}_{3}$ concentration of the flue gas at the heat exchanger inlet was $1.8 \mathrm{ppm}$ and flue gas inlet temperatures ranged from 250 to $280^{\circ} \mathrm{F}$. Figure 5-6 shows measured values of $\mathrm{SO}_{3}$ and corresponding flue gas inlet temperature. Also shown in this graph are calculated values of $\mathrm{SO}_{3}$ dewpoint. The fact that measured flue gas temperatures are significantly higher than the local dewpoint temperatures suggests that the measured values of flue gas $\mathrm{SO}_{3}$ concentration are representative of actual values in the flue gas instead of reduced values due to localized $\mathrm{H}_{2} \mathrm{SO}_{4}$ condensation. 


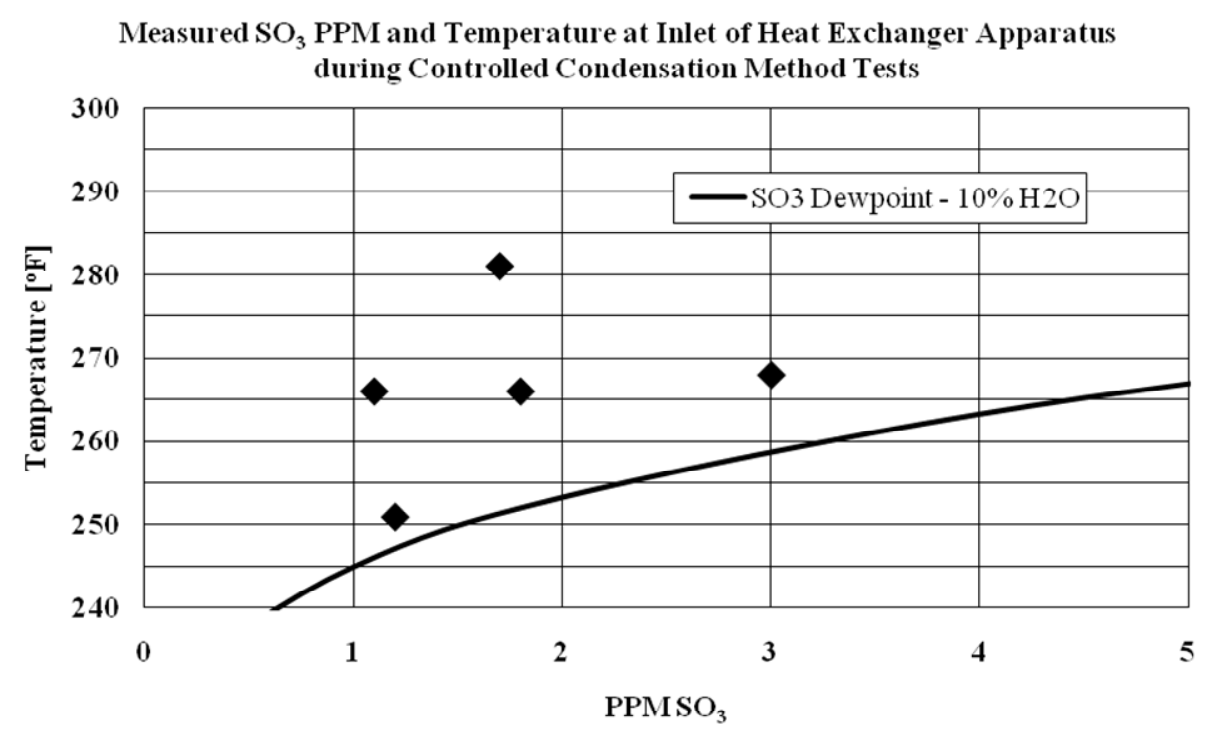

Figure 5-6: Flue Gas Temperature and $\mathrm{SO}_{3}$ Concentration at Heat Exchanger Inlet. Comparison to Acid Dew Point Temperatures.

In some tests, $\mathrm{SO}_{3}$ was injected into the flue gas slip stream upstream of the heat exchangers, resulting in $\mathrm{SO}_{3}$ concentrations up to 39 PPM. The acid trap was installed between heat exchangers 1 and 2 and was maintained at temperatures below the local $\mathrm{SO}_{3}$ dew-point temperatures. Figure 5-7 shows the $\mathrm{SO}_{3}$ dew-point temperature for various water vapor concentrations.

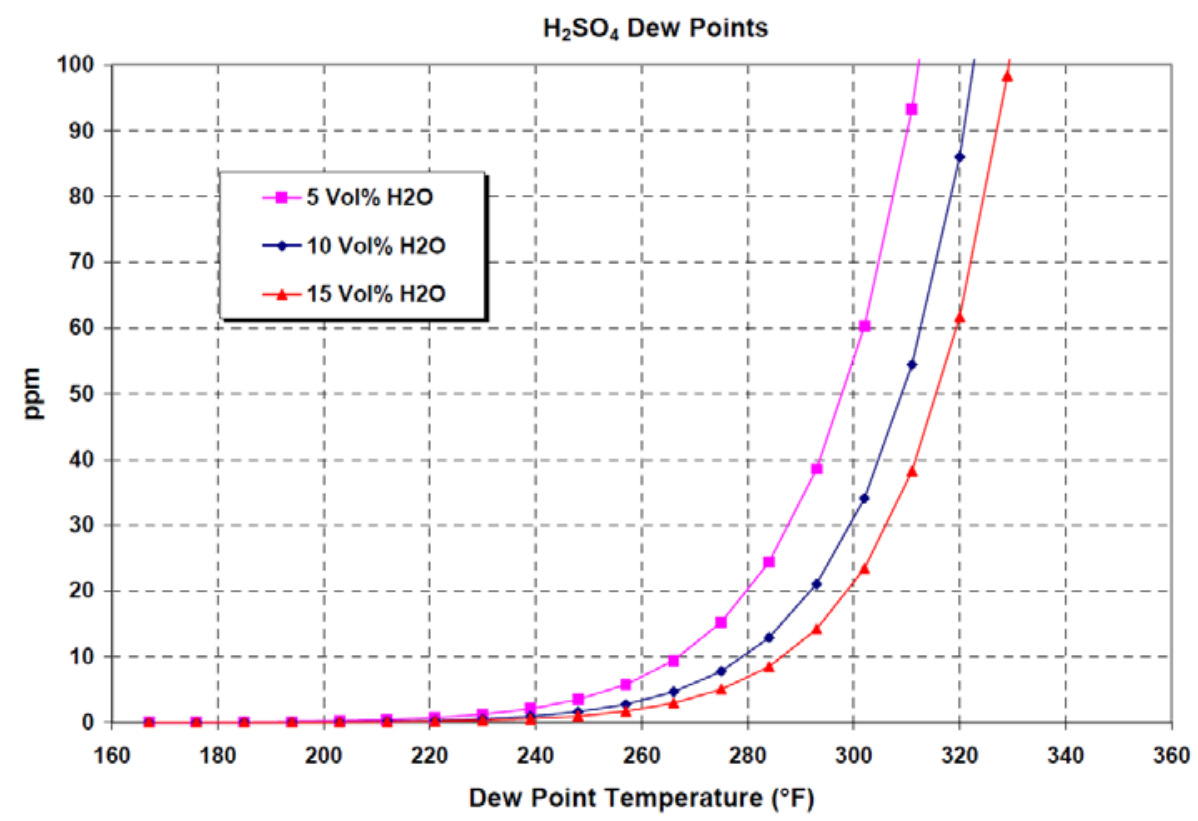

Figure 5-7: Acid Dew Point Temperature as a Function of Vapor Phase Concentration of $\mathrm{SO}_{3}$. 
Table 5-4 shows measured $\mathrm{SO}_{3}$ concentrations in the flue gas upstream and downstream of the apparatus for six tests when $\mathrm{SO}_{3}$ was injected. (Also shown in Table 5-4 are $\mathrm{SO}_{3}$ concentrations in the flue gas upstream of the apparatus for the tests without $\mathrm{SO}_{3}$ injection.) Table 5-5 shows the measured $\mathrm{SO}_{3}$ concentrations at the inlet and exit of the acid trap for the $\mathrm{SO}_{3}$ injection tests. The average reduction of $\mathrm{SO}_{3}$ was $24.1 \%$ across the entire system (trap and heat exchangers) and $10.2 \%$ across the trap. Because the flue gas temperature exiting the entire apparatus was $100^{\circ} \mathrm{F}$, it was expected that most, if not all, of the $\mathrm{SO}_{3} / \mathrm{H}_{2} \mathrm{SO}_{4}$ would condense in the apparatus. However, it is possible that some $\mathrm{H}_{2} \mathrm{SO}_{4}$ existed as a mist and was carried by the flue gas through the heat exchanger and trap apparatus. If so, use of a demister or acid trap downstream of the heat exchanger array would reduce the acid mist concentration in the flue gas duct.

Flue Gas from Unit C. Unit C fires a bituminous coal and has a wet FGD for $\mathrm{SO}_{2}$ control. The heat exchanger system was assembled on a grating adjacent to the flue gas duct at the exit of the wet FGD.

Table 5-4: Measured $\mathrm{SO}_{3}$ Concentration and Flue Gas Temperature, Both With and Without $\mathrm{SO}_{3}$ Injection.

\begin{tabular}{|c|c|c|c|c|c|c|c|c|}
\hline \multirow[b]{3}{*}{ Date } & \multicolumn{4}{|c|}{ Process Conditions } & \multicolumn{4}{|c|}{$\begin{array}{c}\text { Measured } \mathrm{SO}_{3} \text { Concentrations } \\
\text { in Flue Gas [PPM] }\end{array}$} \\
\hline & \multicolumn{2}{|c|}{$\begin{array}{l}\text { Flow Rate } \\
\mathrm{lbm} / \mathrm{hr}\end{array}$} & \multicolumn{2}{|c|}{$\begin{array}{l}\text { Bulk Flue Gas } \\
\text { Temp }{ }^{\circ} \mathrm{F}\end{array}$} & \multirow{2}{*}{$\begin{array}{c}\mathrm{No} \mathrm{SO}_{3} \\
\text { Injected } \\
\text { Inlet }\end{array}$} & \multicolumn{3}{|c|}{$\begin{array}{l}\mathrm{SO}_{3} \text { Injected into Gas } \\
\text { Upstream of System }\end{array}$} \\
\hline & Gas & Water & Inlet & Exit & & Inlet & Exit & $\begin{array}{c}\text { Total } \\
\text { Reduction }\end{array}$ \\
\hline $6 / 14 / 2010$ & 352 & 312 & 270 & 107 & - & 15.7 & 12.3 & $21.3 \%$ \\
\hline $6 / 15 / 2010$ & 317 & 346 & 268 & 98 & 3.0 & 19.1 & - & - \\
\hline 6/16/2010 & 329 & 154 & 251 & 103 & 1.2 & 23.1 & 19.2 & $17.0 \%$ \\
\hline $6 / 17 / 2010$ & 312 & 622 & 266 & 92 & 1.1 & 21.7 & 18.5 & $14.5 \%$ \\
\hline $6 / 18 / 2010$ & 367 & 615 & 281 & 91 & 1.7 & 23.2 & 14.7 & $36.6 \%$ \\
\hline $6 / 21 / 2010$ & 324 & 147 & 266 & 107 & 1.8 & 39.4 & 27.2 & $30.9 \%$ \\
\hline \multicolumn{8}{|c|}{ Average Total Reduction } & $24.1 \%$ \\
\hline
\end{tabular}


Table 5-5: Measured $\mathrm{SO}_{3}$ Concentration at Inlet and Exit of Acid Trap: Tests with $\mathrm{SO}_{3}$ Injection

\begin{tabular}{|c|c|c|c|c|}
\hline Date & $\begin{array}{c}\text { Trap Inlet } \\
\text { PPM }\end{array}$ & $\begin{array}{l}\text { Trap Exit } \\
\text { PPM }\end{array}$ & $\begin{array}{l}\text { Trap Temp } \\
{ }^{\circ} \mathrm{F}\end{array}$ & $\begin{array}{c}\text { Reduction in } \\
\mathrm{SO}_{3}\end{array}$ \\
\hline $6 / 15 / 2010$ & 16.5 & 16.1 & 171 & $2.2 \%$ \\
\hline $6 / 16 / 2010$ & 22.1 & 17.0 & 189 & $23.0 \%$ \\
\hline $6 / 17 / 2010$ & 25.8 & 21.1 & 158 & $18.3 \%$ \\
\hline $6 / 18 / 2010$ & 19.6 & 17.6 & 184 & $10.0 \%$ \\
\hline $6 / 21 / 2010$ & 30.0 & 30.7 & 190 & $-2.3 \%$ \\
\hline \multicolumn{4}{|c|}{ Average Reduction Across Trap } & $10.2 \%$ \\
\hline \multicolumn{4}{|c|}{ Average Trap Temperature } & 178 \\
\hline
\end{tabular}

Sulfuric Acid Deposition. Some of the tests at Unit C were run to determine acid deposition characteristics as a function of configuration of the heat exchanger system. The four configurations tested (Figure 5-8) include heat exchangers $H X 1, H X 2$, HX3 and HX4 arranged in series (Configuration 1), an "acid trap" located upstream of HX1 (Configuration 2), an "acid trap" located between HX1 and HX2 (Configuration 3), and acid traps located upstream and downstream of HX1 (Configuration 4). Referred to as "Traps 1 and 2" in this report, the acid traps consist of closely-spaced vertical plates aligned parallel to the direction of flow. Since the heat exchanger apparatus was installed just downstream of the wet FGD and the flue gas entering the apparatus was saturated with water vapor, the flue gas entering the acid traps contained both vapor phase $\mathrm{H}_{2} \mathrm{SO}_{4}$ and a sulfuric acid mist.

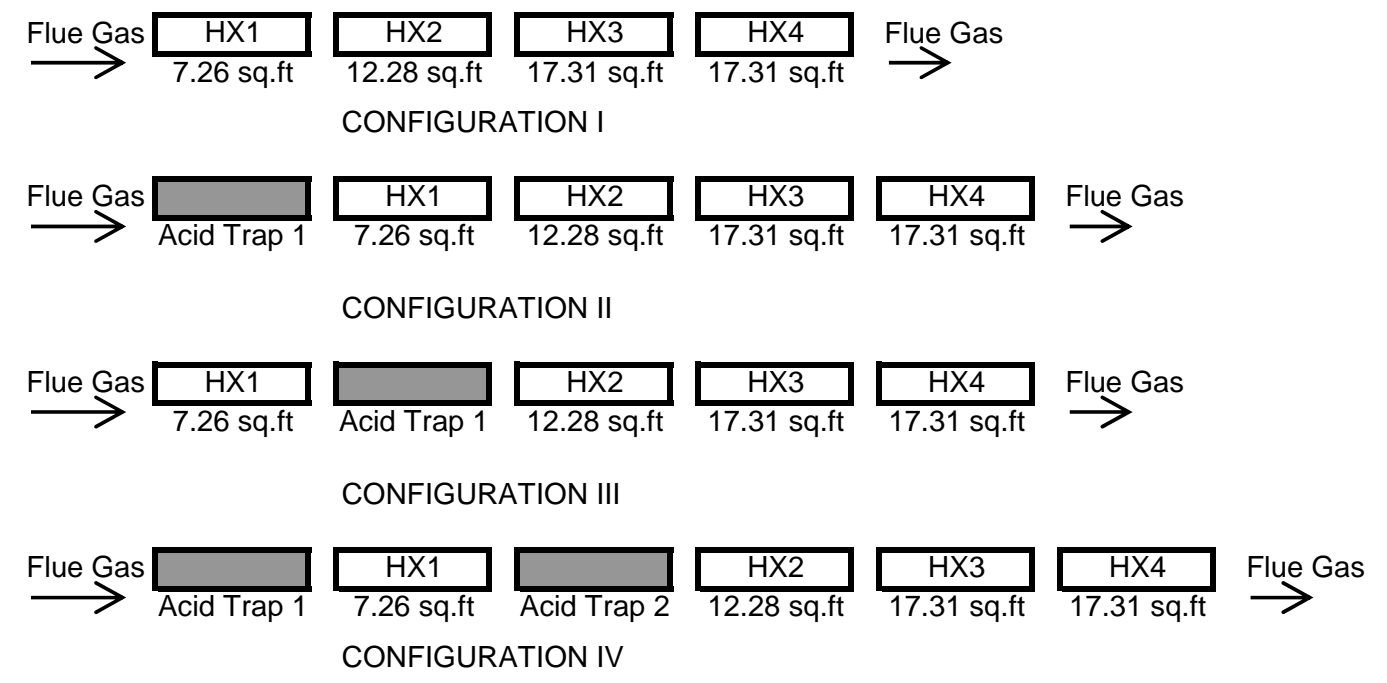

Figure 5-8: Heat Exchanger Configurations Tested at Plant Yates 
Figure 5-9 shows the sulfuric acid concentrations of the acid-water solutions which formed on the four heat exchangers when they were arranged in Configuration 1. With each heat exchanger, there was some variation in sulfuric acid concentration from one day to the next, most likely due to day-to-day variations in flue gas vapor phase $\mathrm{H}_{2} \mathrm{SO}_{4}$ concentrations and in water condensation rate. The data also show sulfuric acid concentrations varying from one heat exchanger to the next, with a peak concentration of $1400 \mathrm{mg} / \mathrm{L}$ on HX2 and the lowest concentration (33 mg/L) on HX4. Figure 5-10 shows the corresponding sulfate flux values $\left(\mathrm{mg} / \mathrm{ft}^{2} \mathrm{~L}\right)$ for the four heat exchangers.

Figure 5-11 shows, for three days of testing of Configurations I and II with fixed process conditions, the effects of the presence of Trap 1 on the flux of dissolved sulfate draining from $\mathrm{HX} 1$ in condensed water. In all three cases, the presence of Trap 1 resulted in reduced acid flux from $\mathrm{HX1}$, with the reduction averaging 33 percent.

Figure 5-12 shows the presence of either Trap 1 and/or Trap 2 (Configurations III and IV) resulted in a decrease in acid flux on HX2 for three of the four days of tests, with the average decrease being 42 percent.

Figures 5-13 and 5-14 show the sulfate deposition rates in $\mathrm{mg} / \mathrm{hr}$ onto Traps 1 and 2 (Configuration IV) and the four heat exchangers during two tests, each two hours long. These data show that Trap 1 captured from 62 to 76 percent of the total sulfuric acid captured in the heat exchanger system, with the remaining acid divided between the four heat exchangers and Trap 2 (see Table 5-6).

These results on sulfuric acid deposition show that the presence of an acid trap resulted in reduced acid flux on heat exchangers positioned just downstream of the trap, with reductions in acid flux averaging 33 and 42 percent for the two cases tested. Measurements of total acid deposition rates show that the trap located upstream of the first heat exchanger (Trap 1) removed from 62 to 76 percent of the sulfuric acid captured in the heat exchanger system. 


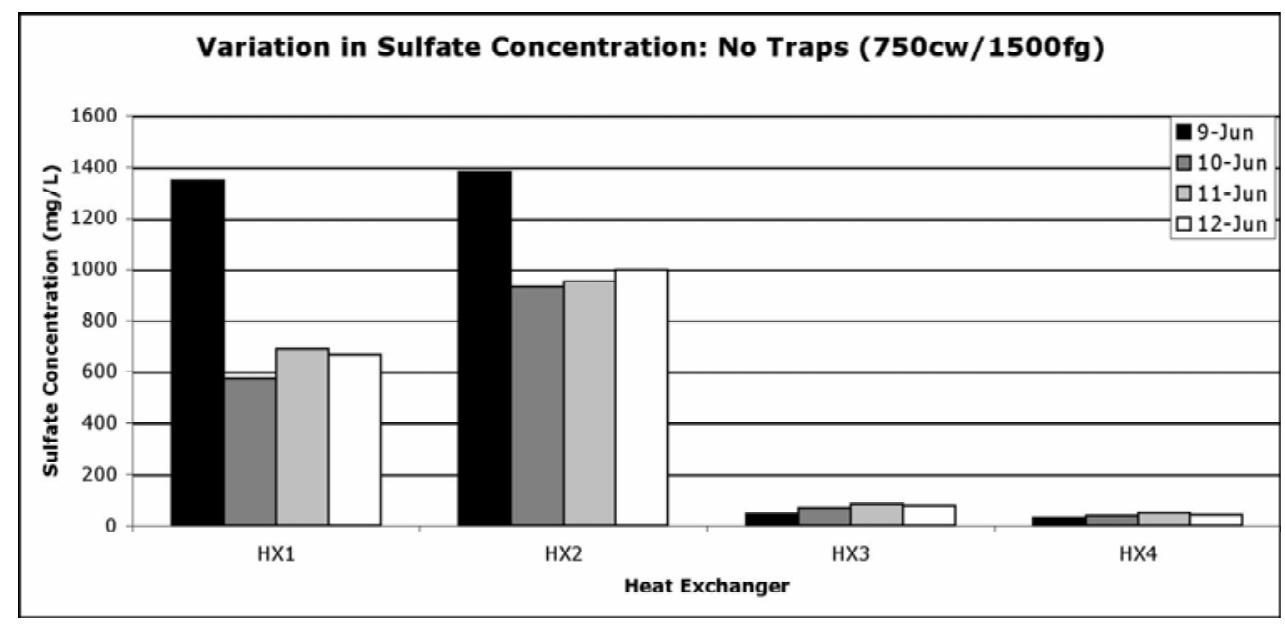

Figure 5-9: Condensate Sulfate Concentration from the Four Heat Exchangers: Without Acid Traps

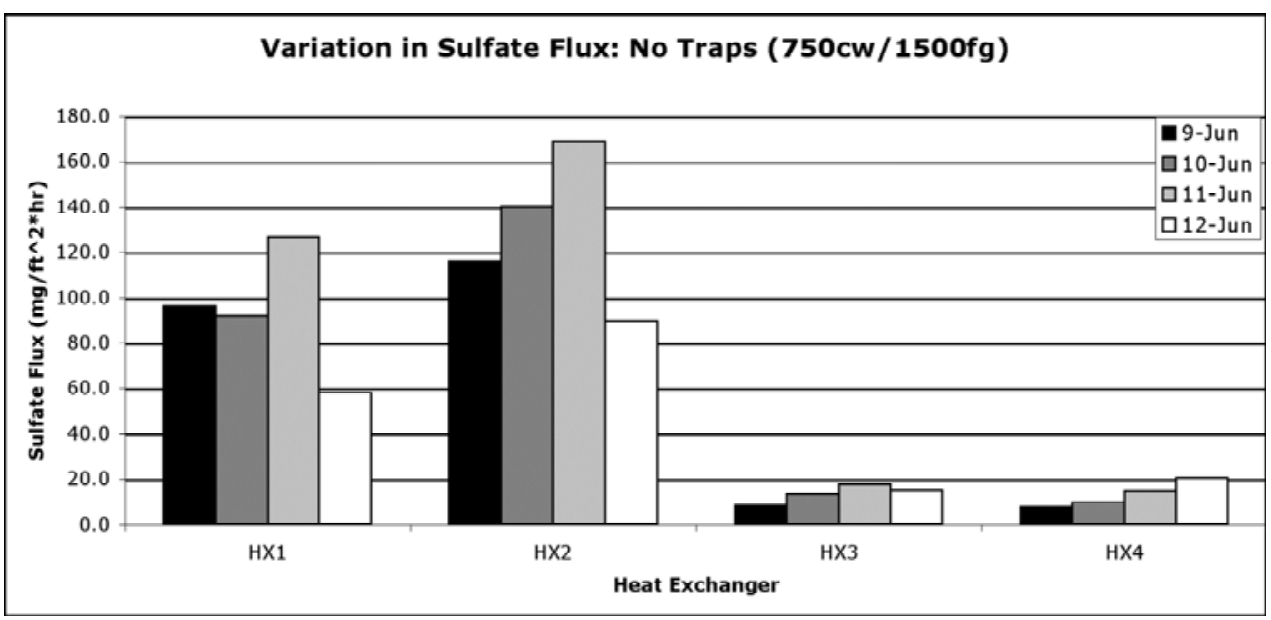

Figure 5-10: Sulfate Flux on the Four Heat Exchangers: Without Acid Traps

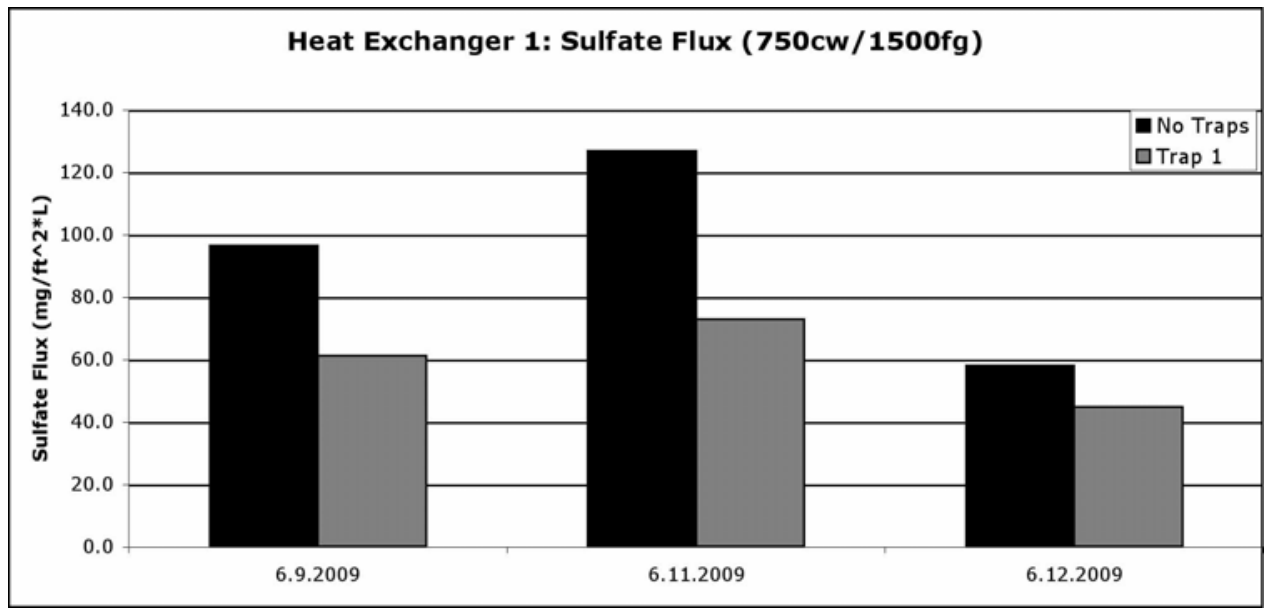

Figure 5-11: Sulfate Flux on HX1: Comparison of No Traps to Trap 1 


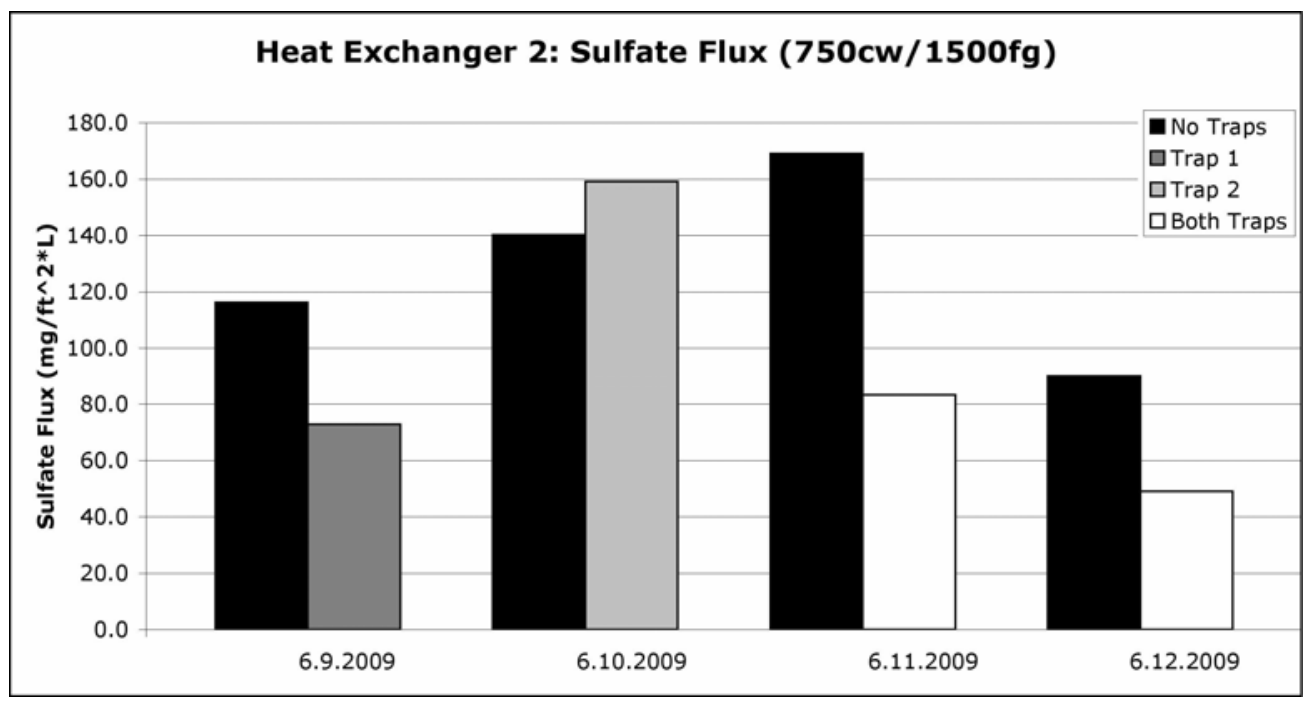

Figure 5-12: Sulfate Flux on HX2: Comparison of the Four HX Configurations

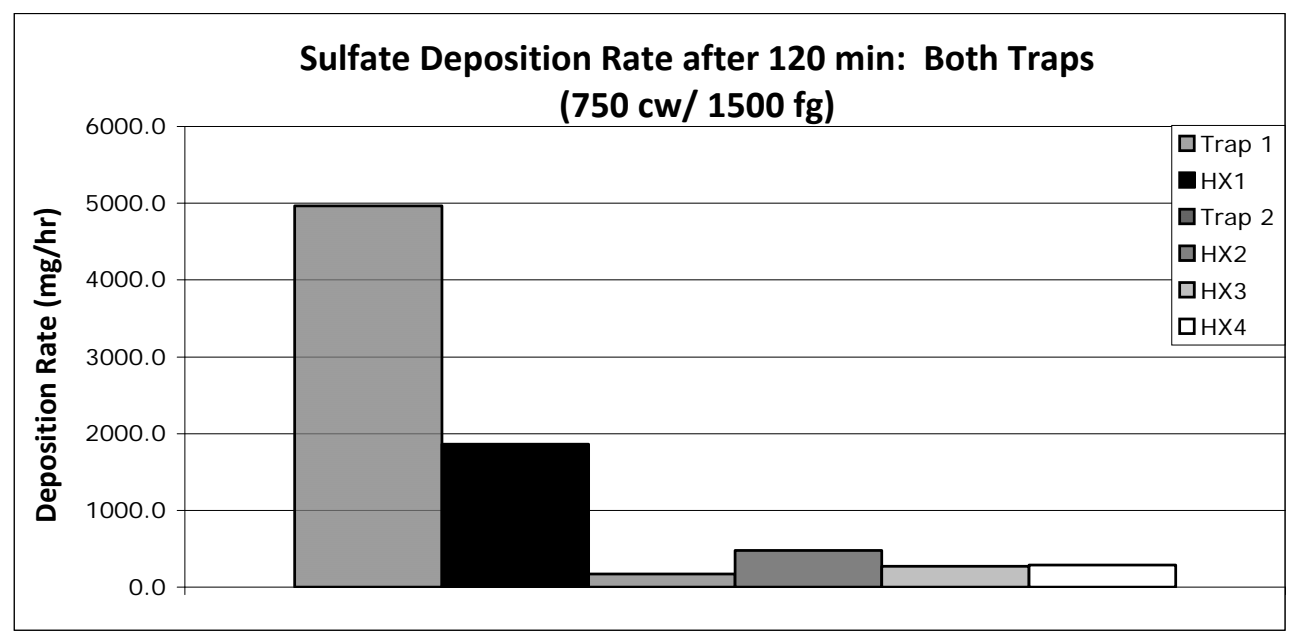

Figure 5-13: Sulfate Deposition Rate on All Four Heat Exchangers and the Acid Traps: First Two Hour Test Period

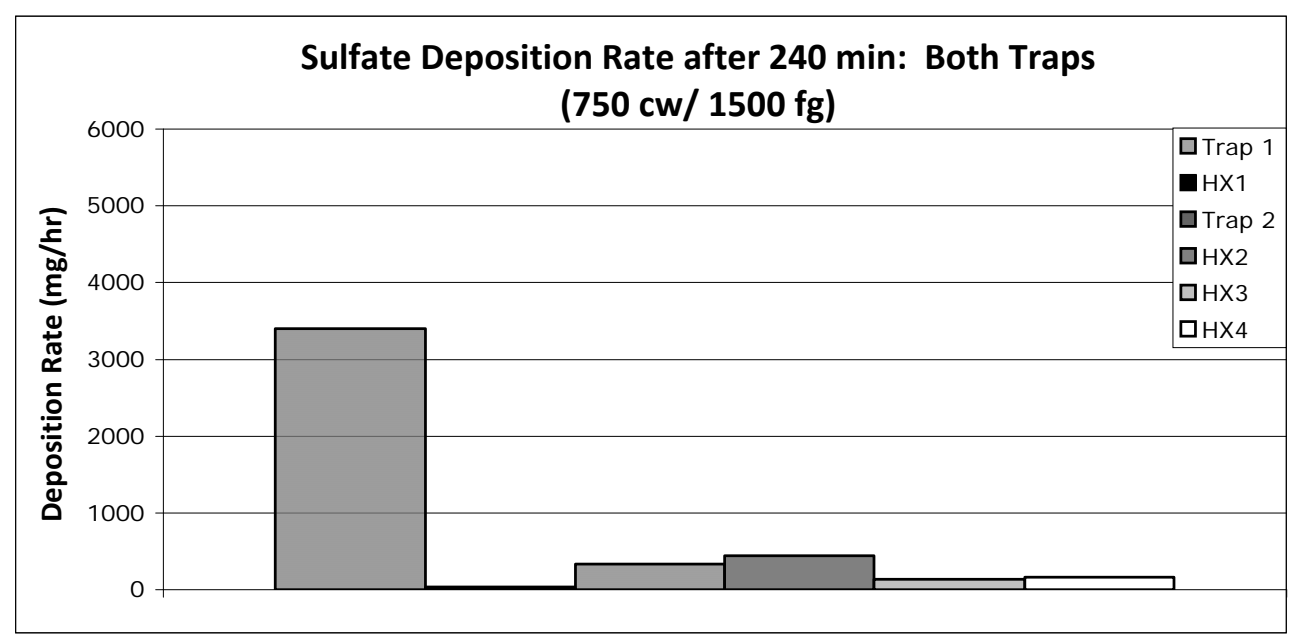

Figure 5-14: Sulfate Deposition Rate on All Four Heat Exchangers and the Acid Traps: Second Two Hour Test Period 
Table 5-6: Measurements of Sulfate Concentration, Total Liquid Deposition and Sulfate Deposition Rates

\begin{tabular}{|c|c|c|c|}
\hline Test 1 & $\begin{array}{c}\text { Sulfate } \\
\text { Concentration } \\
(\mathrm{mg} / \mathrm{L})\end{array}$ & $\begin{array}{l}\text { Total Liquid } \\
\text { Deposition } \\
\text { During Two } \\
\text { Hour Test (ml) }\end{array}$ & $\begin{array}{c}\text { Sulfate } \\
\text { Deposition Rate } \\
\text { (mg/hr) }\end{array}$ \\
\hline Trap 1 & 9240.0 & 1075.0 & 4966.5 \\
\hline $\mathrm{HX1}$ & 1380.0 & 2700.0 & 1863.0 \\
\hline Trap 2 & 4470.0 & 75.0 & 167.6 \\
\hline $\mathrm{HX} 2$ & 243.0 & 3940.0 & 478.7 \\
\hline $\mathrm{H} \times 3$ & 80.7 & 6740.0 & 272.0 \\
\hline $\mathrm{HX} 4$ & 65.4 & 8820.0 & 288.4 \\
\hline Test 2 & $\begin{array}{c}\text { Sulfate } \\
\text { Concentration } \\
\text { (mg/L) }\end{array}$ & $\begin{array}{c}\text { Total Liquid } \\
\text { Deposition } \\
\text { During Two } \\
\text { Hour Test }(\mathrm{ml}) \\
\end{array}$ & $\begin{array}{c}\text { Sulfate } \\
\text { Deposition Rate } \\
\text { (mg/hr) }\end{array}$ \\
\hline Trap 1 & 8670.0 & 785.0 & 3403.0 \\
\hline $\mathrm{HX1}$ & 28.7 & 2320.0 & 33.3 \\
\hline Trap 2 & 8890.0 & 75.0 & 333.4 \\
\hline $\mathrm{HX} 2$ & 234.0 & 3740.0 & 437.6 \\
\hline $\mathrm{HX3}$ & 49.7 & 5250.0 & 130.5 \\
\hline $\mathrm{HX} 4$ & 37.6 & 8800.0 & 165.4 \\
\hline
\end{tabular}

Gypsum Deposition. There is carryover of acid mist containing fine gypsum $\left(\mathrm{CaSO}_{4}\right)$ particles in the flue gas from the wet FGD at Unit C. This is of concern because of the potential for having gypsum deposits fouling the heat exchangers and thus decreasing rates of heat and mass transfer and increasing pressure drop. The condensate draining from the heat exchangers was analyzed to determine the concentrations of calcium in the various condensate streams. The results are shown in Figure 5-15 for one set of process conditions. These data indicate that calcium deposited throughout the heat exchanger array, but with the largest calcium concentration appearing in the condensate draining off of $\mathrm{HX1}$. The data also show that use of an acid trap upstream of the first heat exchanger (Configuration II) resulted in a 60 percent reduction in calcium concentration on HX1. (Note that while the data on calcium concentrations in the condensate provide evidence that gypsum penetrated the heat exchanger array, the data do not indicate the extent to which gypsum deposits would have developed on the heat exchanger tubes over the long term.) 


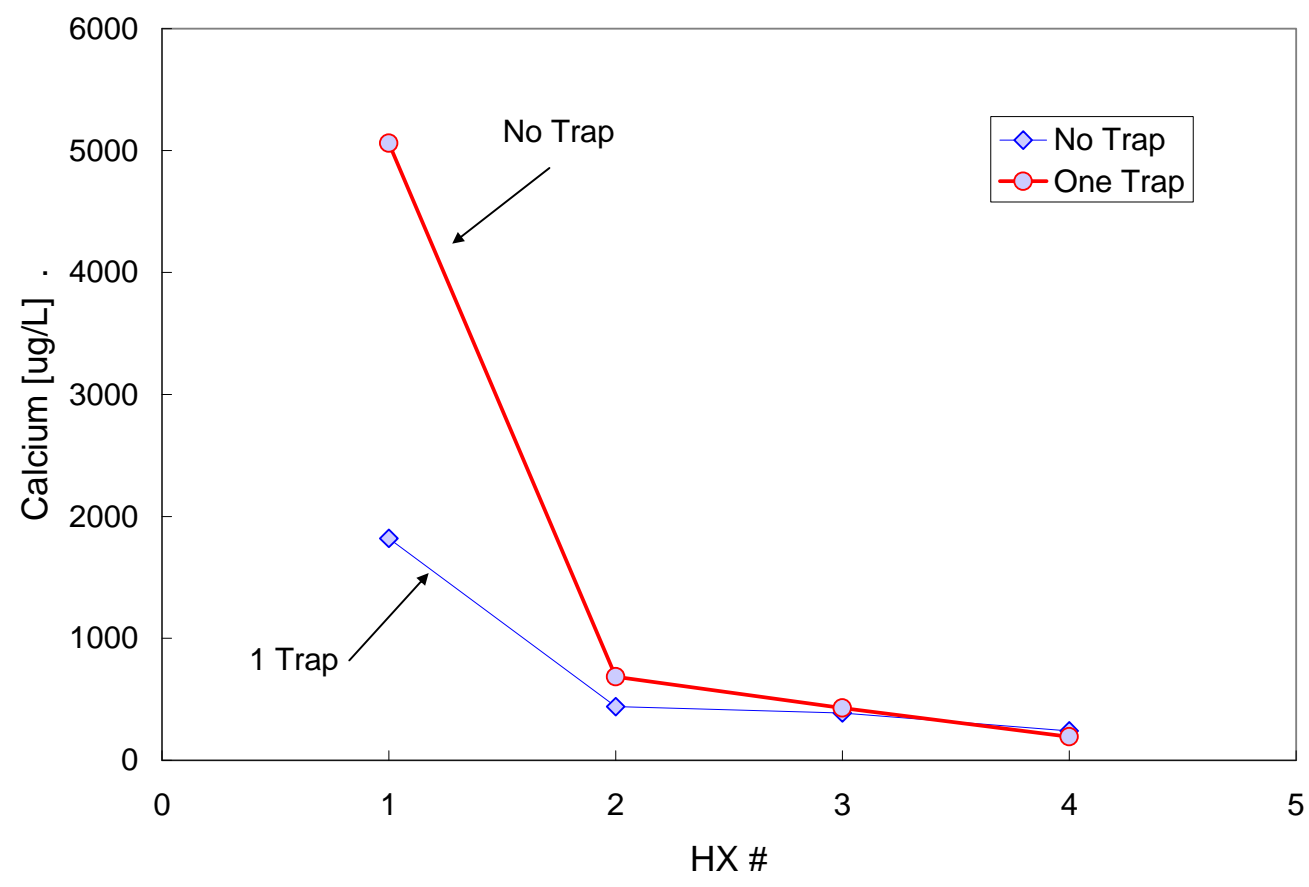

Figure 5-15: Calcium Concentration in Condensate on Four Heat Exchangers: Comparison of No Trap with Trap 1

\section{Conclusions}

Tests at Gas-Fired Boiler. Acid deposition tests were performed with flue gas from a natural gas-fired boiler, with sulfur trioxide being injected into the flue gas to form a sulfuric acid vapor component in the flue gas. Flue gas inlet temperature and flue gas and cooling water flow rates were adjusted to establish tube wall temperatures which were above the water vapor dew point temperature and below the sulfuric acid dew point temperature in the first heat exchanger and acid trap. Controlled Condensation measurements of flue gas $\mathrm{SO}_{3}$ concentrations at the inlet and exit of the acid trap showed an average $\mathrm{SO}_{3}$ reduction of 13.7 percent across the acid trap in the gas-fired boiler tests.

Tests at Unit B. The tests at Unit B were carried out with the heat exchanger apparatus located next to one of the induced draft fans and a slip stream of flue gas being taken at the fan discharge. As was the case with the tests at the gas-fired boiler, flue gas and cooling water flow rates were adjusted to establish tube wall temperatures 
which were above the water vapor dew point temperature and below the sulfuric acid dew point temperature in the first heat exchanger and acid trap.

Tests performed with $\mathrm{SO}_{3}$ injected into the flue gas upstream of the first heat exchanger, resulted in inlet $\mathrm{SO}_{3}$ concentrations which were as high as $39 \mathrm{ppm}$. The acid trap reduced the $\mathrm{SO}_{3}$ vapor phase concentration entering the first heat exchanger by 10.2 percent. In addition, the overall reduction of flue gas $\mathrm{SO}_{3}$ concentration between the inlet of the first heat exchanger and the exit of the last heat exchanger was 24.1 percent.

Tests at Unit C. In the tests at Unit $\mathrm{C}$, the heat exchanger system was installed just downstream of a wet FGD, with acid trap temperatures just below the water vapor dew point temperature.

The test data show that the presence of an acid trap resulted in reduced sulfuric acid flux on heat exchangers positioned just downstream of the trap, with reductions in flux averaging 33 and 42 percent for the two cases tested. Measurements of total acid flow rates showed that the trap located upstream of the first heat exchanger captured from 62 to 76 percent of the total sulfuric acid which was captured by the heat exchanger system.

There is carryover of acid mist containing fine gypsum $\left(\mathrm{CaSO}_{4}\right)$ particles in the flue gas from the wet FGD at Unit $C$. This is of concern because of the potential for having gypsum deposits fouling the heat exchangers and decreasing rates of heat and mass transfer and increasing pressure drop. The condensate draining from the heat exchangers was analyzed to determine the concentrations of calcium in the various condensate streams. The data indicate that calcium deposited throughout the heat exchanger array, but with the largest calcium concentration appearing in the condensate draining from HX1. The data also show that use of an acid trap upstream of the first heat exchanger resulted in a 60 percent reduction in calcium concentration on HX1. 
Final Comments. In summary, the results from the three boilers show that acid traps can be effective at reducing the quantities of sulfuric acid flowing into the heat exchangers. At temperatures above the water vapor dewpoint, the acid traps reduced the vapor phase acid concentrations entering the heat exchangers just downstream of the traps by 10.2 to 13.7 percent. At temperatures at or below the water vapor dew point, the presence of an acid trap reduced the sulfuric acid flux on the heat exchanger positioned just downstream of the trap by 33 to 42 percent.

Corrosion test data described elsewhere in this report show that rates of corrosion increase with increasing sulfuric acid concentration for some materials. This suggests that acid traps can be useful in reducing rates of heat exchanger tube wall corrosion. The data also show acid traps can be effective at reducing amounts of sulfuric acid which pass through the heat exchanger array into the downstream ductwork, which is of potential importance for acid emissions control, component life and maintenance costs. 


\section{CHAPTER 6}

\section{CONDENSING HEAT EXCHANGER DESIGN ANALYSES}

\section{Introduction}

The pilot scale heat transfer tests described in Chapter 2 were performed to determine the relationship between inlet flue gas moisture concentration and temperature, heat exchanger operating conditions, and water vapor condensation rate. A theoretical heat and mass transfer model, developed by the project team, was used for predicting rates of heat transfer and water vapor condensation and comparisons were made with pilot scale measurements. These show very good agreement between predicted values and field measurements (for example, see Figures 6-1 to 6-4).

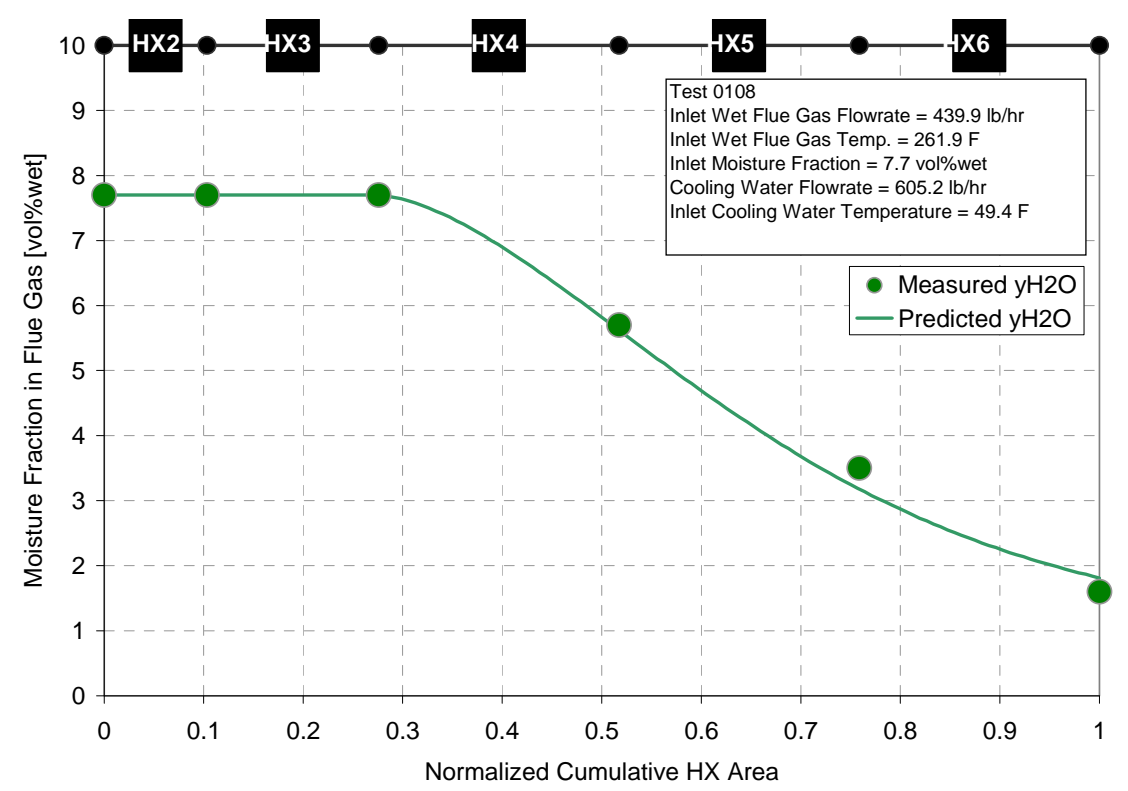

Figure 6-1: Variation of Flue Gas Moisture Fraction with Distance through the Heat Exchanger: Comparison of Predicted and Measured Values 


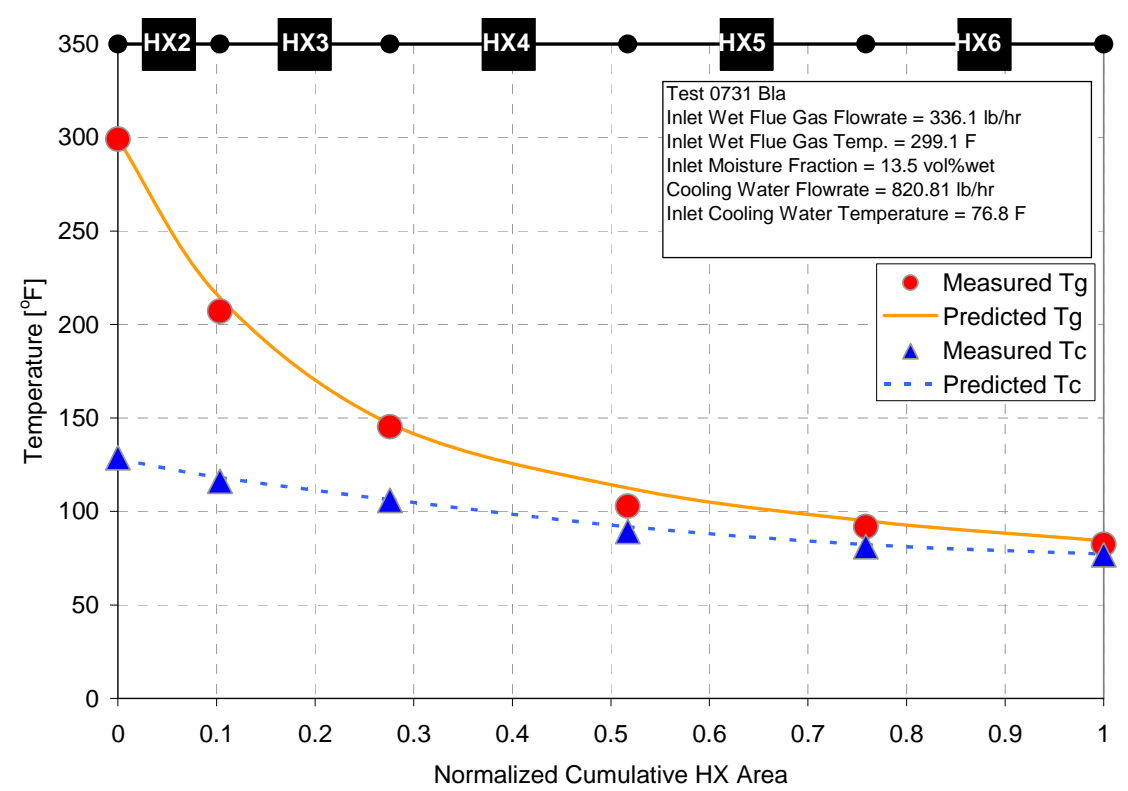

Figure 6-2: Variations of Flue Gas and Cooling Water Temperatures with Distance through the Heat Exchanger: Comparison of Predicted and Measured Values

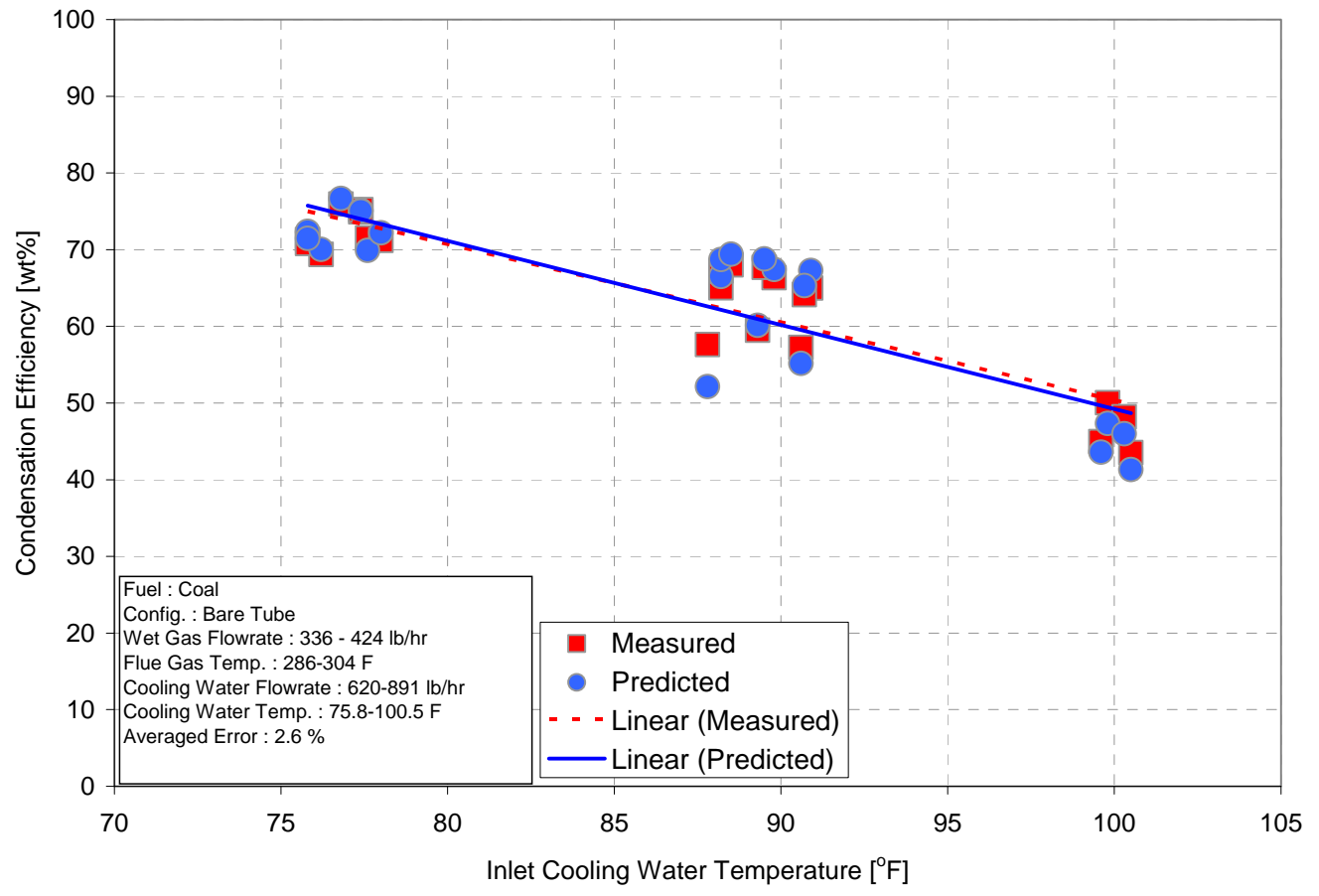

Figure 6-3: Comparison of Predicted and Measured Values of Condensation Efficiency vs. Cooling Water Temperature 


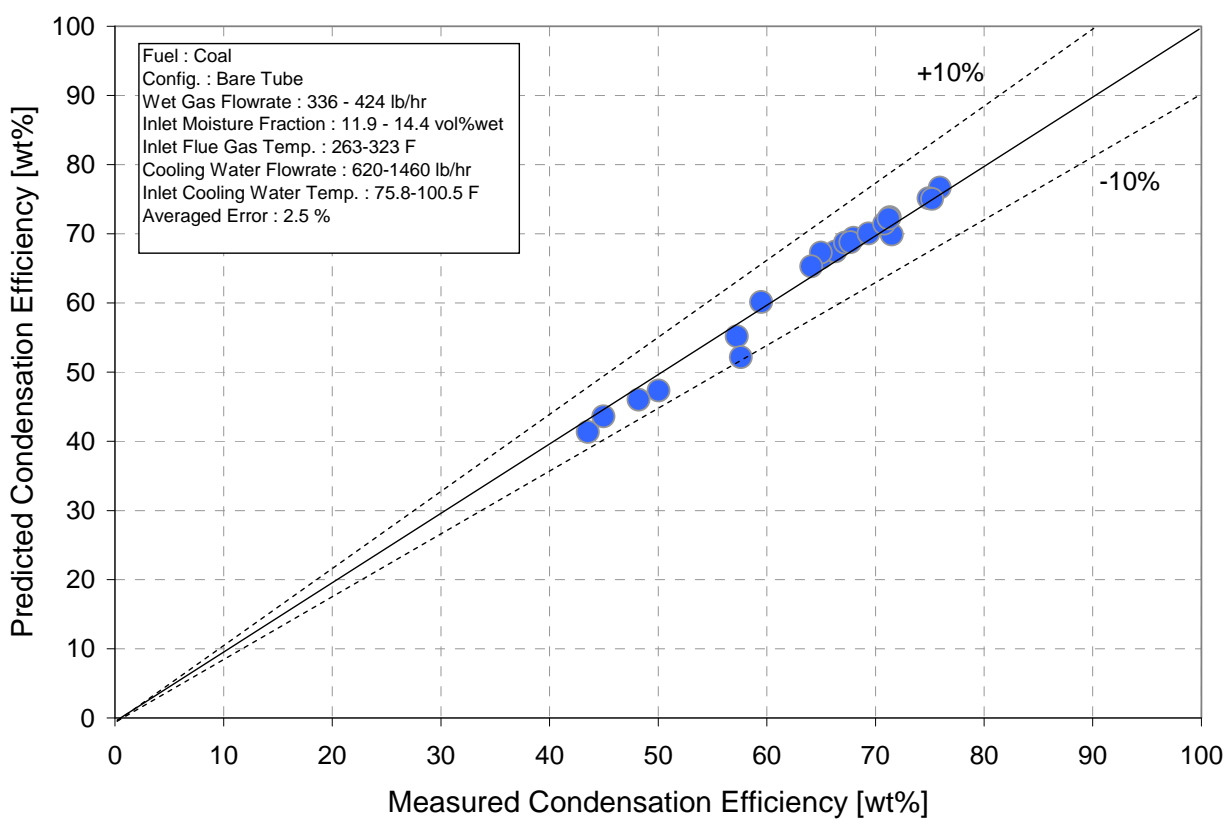

Figure 6-4: Comparison of Predicted and Measured Values of Condensation Efficiency

The computer software, which is described in the following section, was then used to perform analyses to estimate how much flue gas moisture it would be practical to recover from boiler flue gas, the size and cost of the heat exchangers, and flue gas and cooling water pressure drops.

\section{Heat Exchanger Simulation Method}

The heat and mass transfer model used for the simulations assumes a counterflow bare-tube heat exchanger in a duct, with cooling water flowing through the tubes and the gas/water vapor mixture flowing on the outside of the tubes (Reference 1). The software solves finite difference forms of the equations for conservation of energy in the flue gas

$$
\dot{\mathrm{m}}_{\mathrm{g}} * C \mathrm{p}_{\mathrm{g}} * \mathrm{dT}=\mathrm{h}_{\mathrm{g}} *\left(\mathrm{~T}_{\mathrm{g}}-\mathrm{T}_{\mathrm{i}}\right) * \mathrm{dA}
$$

and cooling water

$$
\left[\mathrm{h}_{\mathrm{g}}\left(\mathrm{T}_{\mathrm{g}}-\mathrm{T}_{\mathrm{i}}\right)+\mathrm{h}_{\mathrm{fg}} * \mathrm{k}_{\mathrm{m}}\left(\mathrm{y}_{\mathrm{H}_{2} \mathrm{O}}-\mathrm{y}_{\mathrm{i}}\right)\right] \mathrm{d} \mathrm{d}=\dot{\mathrm{m}}_{\mathrm{c}} * \mathrm{Cp}_{\mathrm{c}} * \mathrm{dT} \mathrm{T}_{\mathrm{c}}
$$


along with the Colburn-Hougen equation, which when condensation occurs, is used to calculate the liquid-vapor interface temperature, $T_{i}$. In the absence of condensation, $T_{i}$ is replaced by the tube wall temperature, $T_{w}$.

$$
h_{g}\left(T_{g}-T_{i}\right)+k_{m} * h_{f g}\left(y_{h_{2} 0}-y_{i}\right)=U_{O}\left(T_{i}-T_{c}\right)
$$

In addition to the governing equations, correlations were used to approximate the heat and mass transfer coefficients. The heat transfer coefficient for the flue gas side was calculated using a correlation for Nussult number for bare tube heat exchangers.

$$
\mathrm{Nu}_{\mathrm{D}}=\mathrm{C} * \operatorname{Re}_{\mathrm{D}, \mathrm{max}}^{\mathrm{m}} * \operatorname{Pr}^{0.36}\left(\frac{\mathrm{Pr}}{\operatorname{Pr}_{\mathrm{s}}}\right)^{0.25}
$$

where $C$ and $m$ are functions of Reynolds number. The respective heat transfer coefficient for the cooling water side is calculated from

$$
\mathrm{Nu}_{\mathrm{D}}=\frac{\left(\frac{\mathrm{f}}{8}\right)(\operatorname{Re} * \mathrm{D}-1000) \operatorname{Pr}}{1+12.7\left(\frac{\mathrm{f}}{8}\right)^{0.5}\left(\operatorname{Pr}^{0.67}-1\right)}
$$

where the parameter $f$ is a function of $\mathrm{Re}_{\mathrm{D}}$. The mass transfer coefficient for water vapor in flue gas is related to the heat transfer coefficient through the following expression.

$$
\mathrm{k}_{\mathrm{m}}=\frac{\mathrm{h}_{\mathrm{g}} * \mathrm{M}_{\mathrm{h}_{2} \mathrm{O}}}{\mathrm{Cp}_{\mathrm{g}} * \mathrm{M}_{\mathrm{g}} * \mathrm{y}_{\mathrm{Im}} * \mathrm{Le}_{\mathrm{g}}^{0.67}}
$$

The final correlation used is the Antoine equation, which is used to calculate interfacial mole fractions of water vapor.

$$
y_{i}=\frac{e^{\left(a-\frac{b}{T_{i}+c}\right)}}{P_{\text {total }}}
$$

Numerical analyses were performed in a step-wise fashion in the axial direction by discretizing the heat transfer surface area into infinitesimal cells. Inlet flue gas temperature and mass flow rate were specified, as well as cooling water mass flow rate, inlet vapor fraction, and inlet cooling water temperature. Because the simulation 
models a cross-flow, counter-flow heat exchanger, the exit cooling water temperature is unknown initially, although it is needed for performing the simulation. To handle this, the code uses a "goal-seek" type analysis, where the cooling water exit temperature is arbitrarily assigned. The code subsequently steps through the heat exchanger one "cell" at a time, where each cell's exit conditions represent the inlet of conditions of the subsequent cell. When the heat exchanger exit conditions are calculated, the calculated cooling water inlet temperature is compared to the known cooling water inlet temperature. At this point, the process is iterated with a new estimated exit cooling water temperature until the calculated and specified inlet cooling water temperatures agree to within 1 percent.

\section{Design of Full-Scale Heat Exchangers}

Heat Exchanger Dimensions and Process Parameters. The heat exchanger simulation code was used to explore alternate designs for full-scale heat exchangers. The general heat exchanger configuration consists of bare wall tubes in a cross flowcounter flow arrangement in a rectangular duct with cooling water flowing inside the tubes and flue gas around the tubes (Figure 6-5). Key process and design parameters include heat transfer surface area, choice of tube material, inlet flue gas temperature and water vapor concentration, inlet cooling water temperature and inlet flue gas and cooling water flow rates.

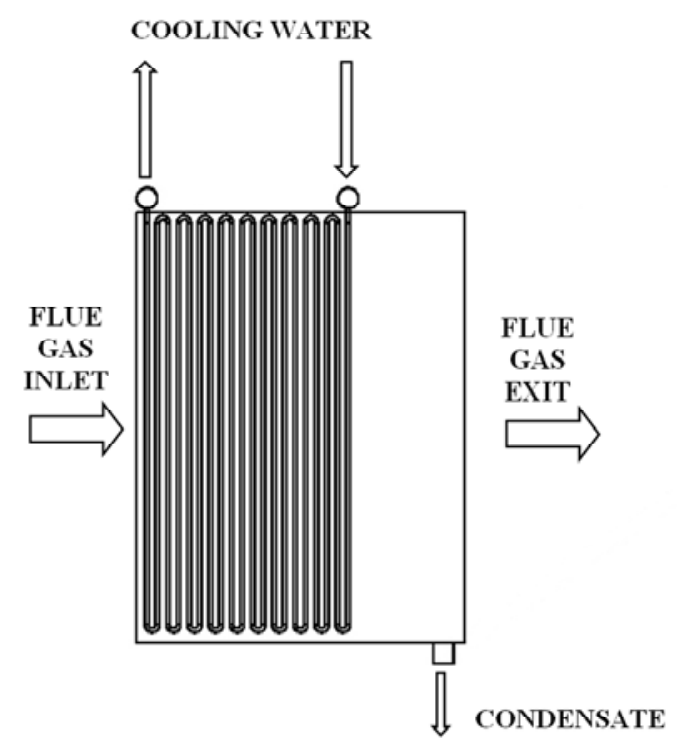

Figure 6-5: Two Dimensional Diagram of Heat Exchanger: Side View. 
The results described in this Chapter are for a $550 \mathrm{MW}$ unit with a 6 million $\mathrm{lbm} / \mathrm{hr}$ flue gas flow rate. Simulations were performed early in this task to identify tube bundle dimensions which would provide a good compromise between heat transfer and pressure drop. The result was an in-line heat exchanger in a $40 \mathrm{ft}$ wide by $40 \mathrm{ft}$ high square duct. The tube bundle consists of 2.375 inch OD tubing with a 0.218 inch wall thickness and with a 6.17 inch center-to-center transverse tube spacing and a center-tocenter 2.97 inch longitudinal tube spacing.

Heat exchanger capital costs were estimated from tube material costs and costs for fabrication and installation. Flue gas pressure drops were calculated using standard correlations for pressure drops in tube bundles and cooling water pressure drops were taken from correlations for pressure drops in cylindrical tubes. These were then used to estimate the incremental power requirements for the induced draft (ID) fan and cooling water pump. Unless otherwise noted, annual power costs are based on full load operation for 7,000 hrs per year at $\$ 50 / \mathrm{MWh}$.

Choice of Tube Material. The laboratory tube material corrosion measurements described in Chapter 4 identified 304 stainless steel as the best candidate for heat exchangers which operate at temperatures below the water vapor dew point temperature and Teflon and Alloy 22 for heat exchangers which operate at temperatures above the water vapor dew point temperature, but below the sulfuric acid dew point temperature. Table 6-1 summarizes the thermal conductivities, tensile strengths and cost/ft of tubing with a 2.375 " OD and 0.218 " thick wall.

Table 6-1: Tube Material Properties and Costs

\begin{tabular}{|l|c|c|c|}
\hline & $\begin{array}{c}\mathrm{k} \\
\left(\mathrm{Btu} / \mathrm{ft} \mathrm{hr}{ }^{\circ} \mathrm{F}\right)\end{array}$ & $\begin{array}{c}\text { Tensile } \\
\text { Strength (ksi) }\end{array}$ & \$/ft \\
\hline Teflon & 0.14 & 3.9 & 40.48 \\
\hline Alloy 22 & 7 & 120 & 110.71 \\
\hline 304 SS & 7 & 100 & 8.60 \\
\hline \multicolumn{3}{|l|}{ 2.375"OD \& 0.218" (5mm) wall } & \multicolumn{3}{|l}{} \\
\cline { 1 - 3 } & &
\end{tabular}


Table 6-1 shows that because of its relatively low cost and high tensile strength and thermal conductivity, 304 SS is the preferred choice for heat exchanger tubing at temperatures below the water vapor dew point.

At locations in the flue gas upstream of the water vapor dewpoint, the choice is between Teflon and Alloy 22. While Teflon is the less expensive of the two materials per foot of tubing, it has extremely low values of thermal conductivity and tensile strength compared to Alloy 22. Heat exchanger design calculations were carried out to determine which would be the more cost effective for the high temperature flue gas cooler application.

Figure 6-6 shows predicted temperature profiles in a heat exchanger with a total surface area of $300,000 \mathrm{ft}^{2}$. Flue gas enters from the left (at $\mathrm{SA}=0 \mathrm{ft}^{2}$ ) at $300^{\circ} \mathrm{F}$ and cooling water enters from the right at $100^{\circ} \mathrm{F}$. The wall and dew point temperatures cross at approximately $240,000 \mathrm{ft}^{2}$ from the flue gas inlet, causing water vapor to condense over the region from 240,000 to $300,000 \mathrm{ft}^{2}$. It was assumed the tubes are made from Alloy 22 for tube wall temperatures above the local water vapor dew point temperature and 304 SS for tube wall temperatures below the local water dew point temperature.

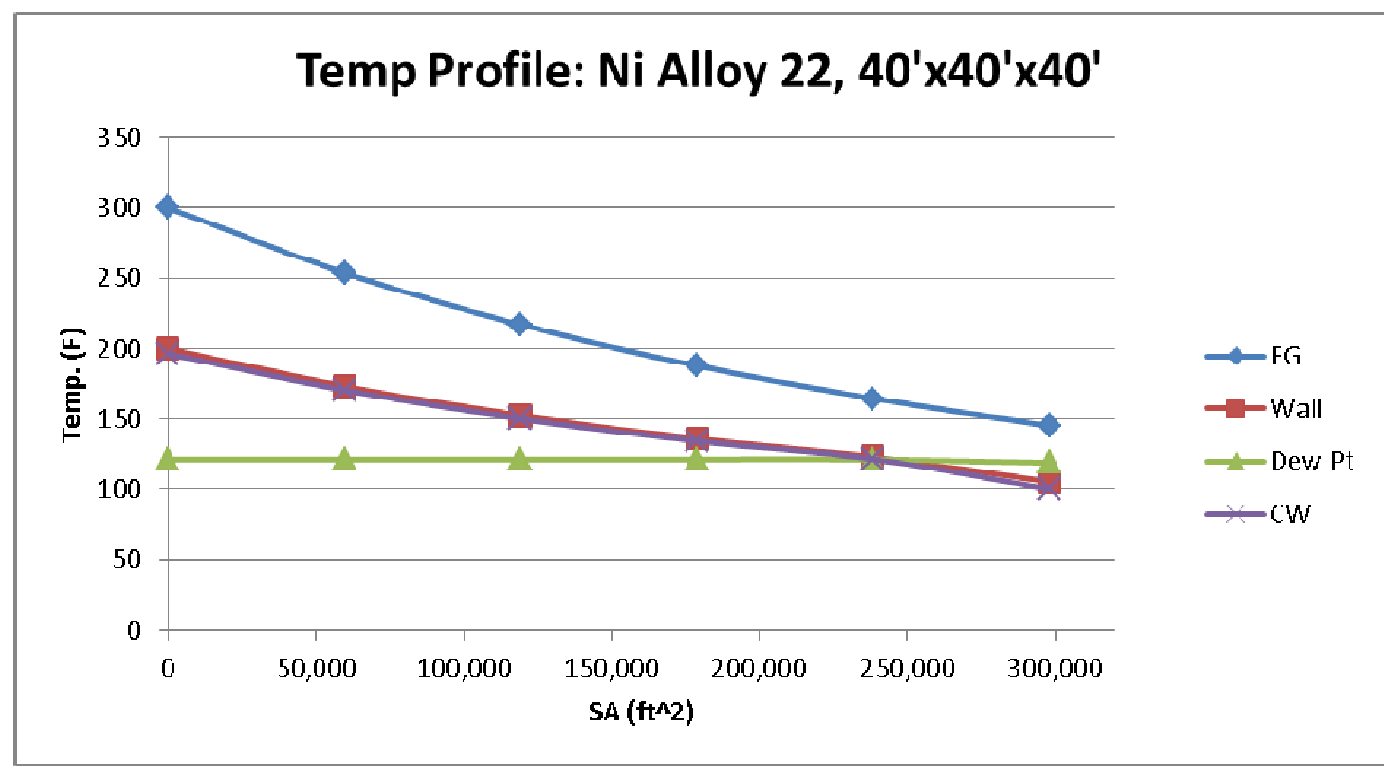

Figure 6-6: Temperature Profiles Through an Alloy 22 Heat Exchanger 
Figure 6-7 shows predicted temperature profiles in a Teflon (PTFE) heat exchanger having the same dimensions, gas and water flow rates and inlet temperatures as the heat exchanger in Figure 6-6. The extremely poor thermal conductivity of the Teflon tube results in tube walls with high thermal resistance, which causes relatively large temperature differences between the outer surface of the tube wall and cooling water. For the process conditions shown, this prevents the outer wall temperature from dropping below the dew point temperature. Thus, while the Teflon heat exchanger would cool the flue gas, no water vapor would condense for this design and process conditions.

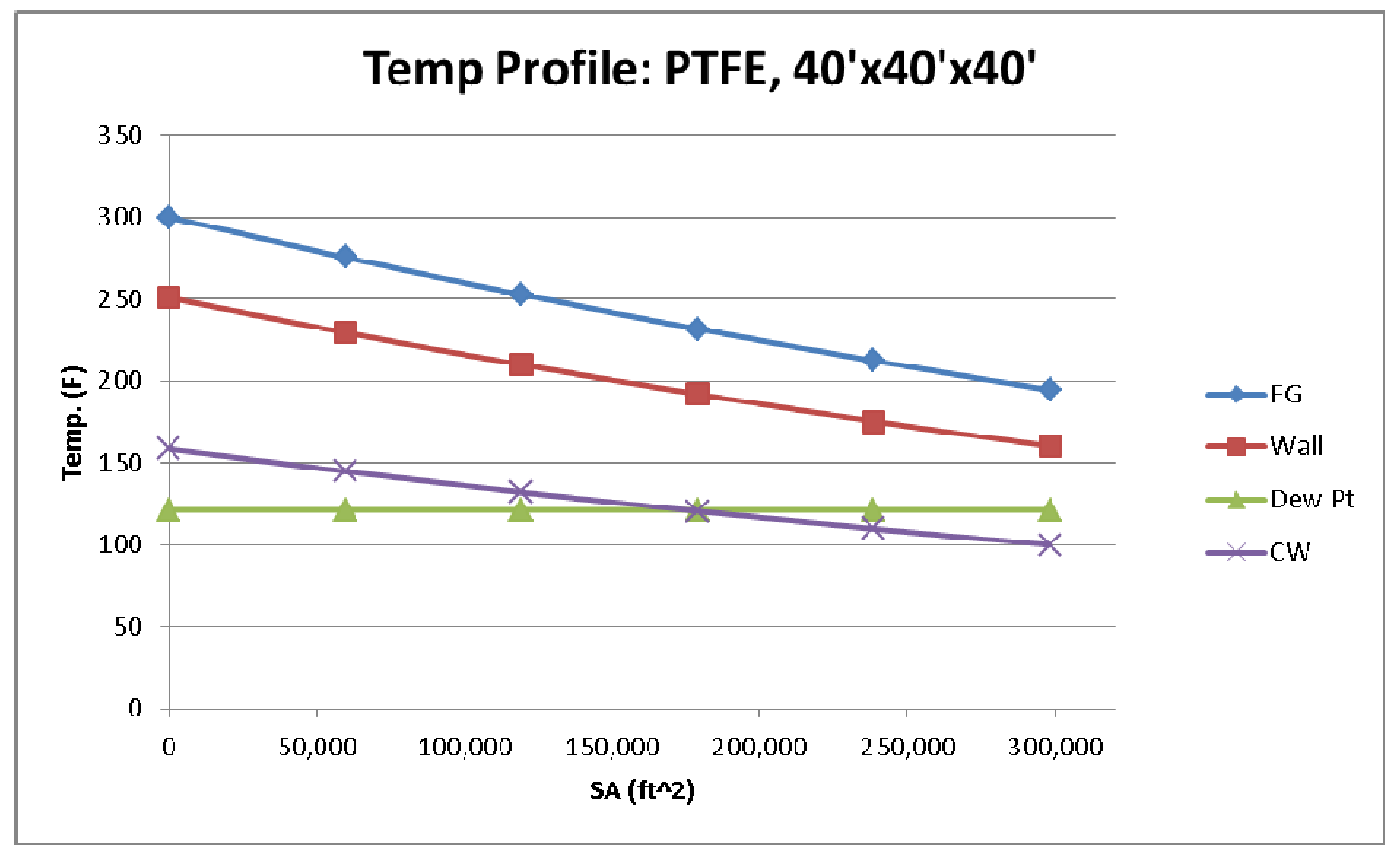

Figure 6-7: Temperature Profiles Through a Teflon Heat Exchanger

Figure 6-8 compares predicted total heat transfer rate as functions of heat exchanger surface area for Teflon and Alloy 22 heat exchangers with the same inlet process conditions. This shows that in order to transfer the same amount of heat, the Teflon heat exchanger would need to have approximately three times the surface area of an Alloy 22 heat exchanger. Figure 6-9 compares predicted total heat transfer as functions of total annual costs for the Teflon and Alloy 22 heat exchangers shown in Figure 6-8. (Note: Annual cost is based on an annual fixed charge rate and the cost of electric power needed to overcome the gas side and cooling water side heat exchanger pressure drops.) This figure shows that the Teflon heat exchanger would result in a 
larger total annual cost than the Alloy 22 heat exchanger for the same rate of heat transfer. While Teflon tubing is less expensive per foot of tubing than Alloy 22 tubing, a larger heat exchanger would be needed with Teflon and this would also result in larger pump and fan power requirements than would be needed for the Alloy 22 heat exchanger. (Note: The analyses described in Figures 6-7 to 6-9 are for heat exchangers with cooling water pressures in excess of 15 psi. To avoid creep damage to Teflon tubes with high internal pressures, thicker tube walls would be needed for Teflon tubes than would be needed for Alloy 22 tubes. However, to facilitate direct comparison of Alloy 22 and PTFE heat exchangers, the same tube wall thickness was used in analyses of each. As a result, the impacts of low thermal conductivity tube walls, when using Teflon tubes, on heat exchanger size and cost and on cooling water and flue gas pressure drops are even larger than are shown in Figures 6-7 to 6-9.)

In summary, Alloy 22 is a better choice than Teflon for heat exchangers which would operate at temperatures above the water vapor dew point temperature. The relatively low thermal conductivity of Teflon would prevent water vapor condensation with Teflon tubes. In addition, the total annual costs for a Teflon heat exchanger would be greater than for a heat exchanger fabricated from Alloy 22 .

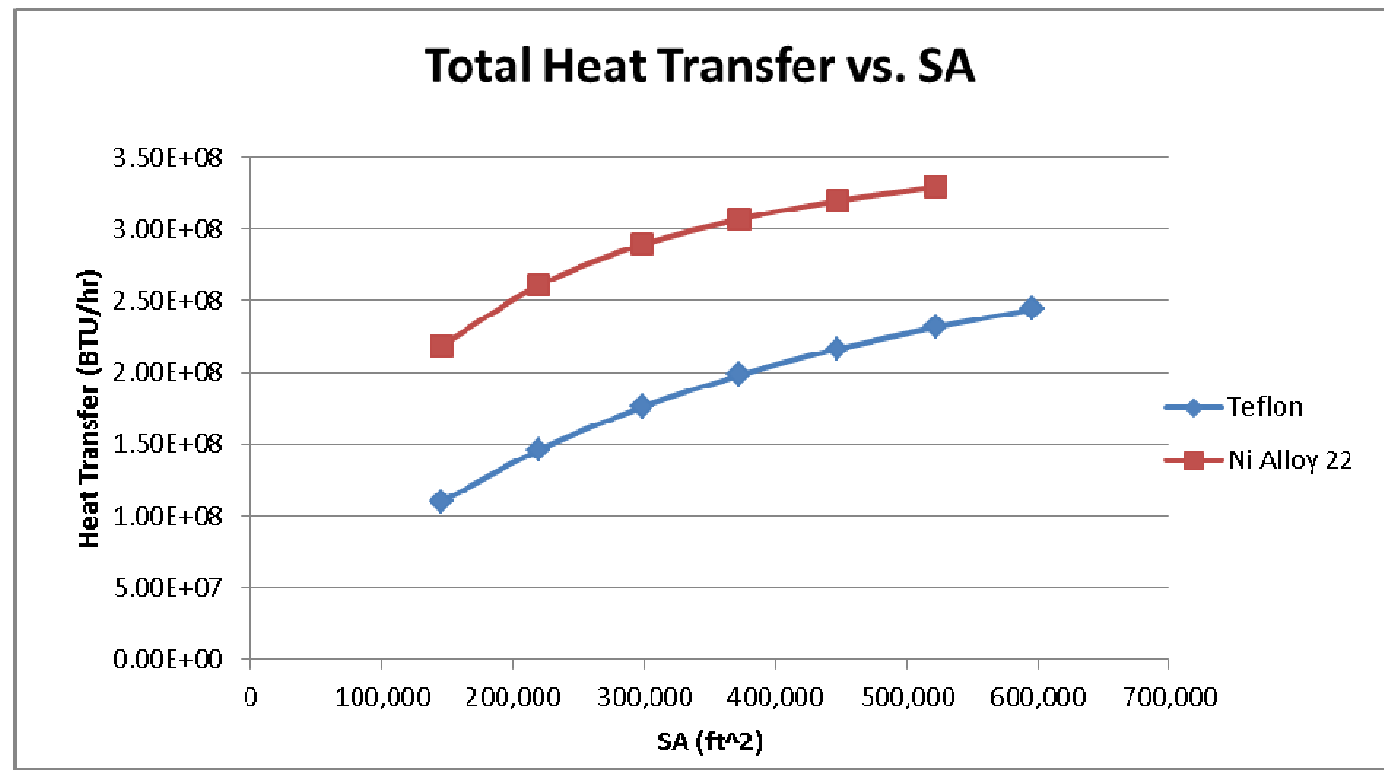

Figure 6-8: Total Heat Transfer vs. Surface Area. Comparison of Teflon and Alloy 22 Heat Exchangers 


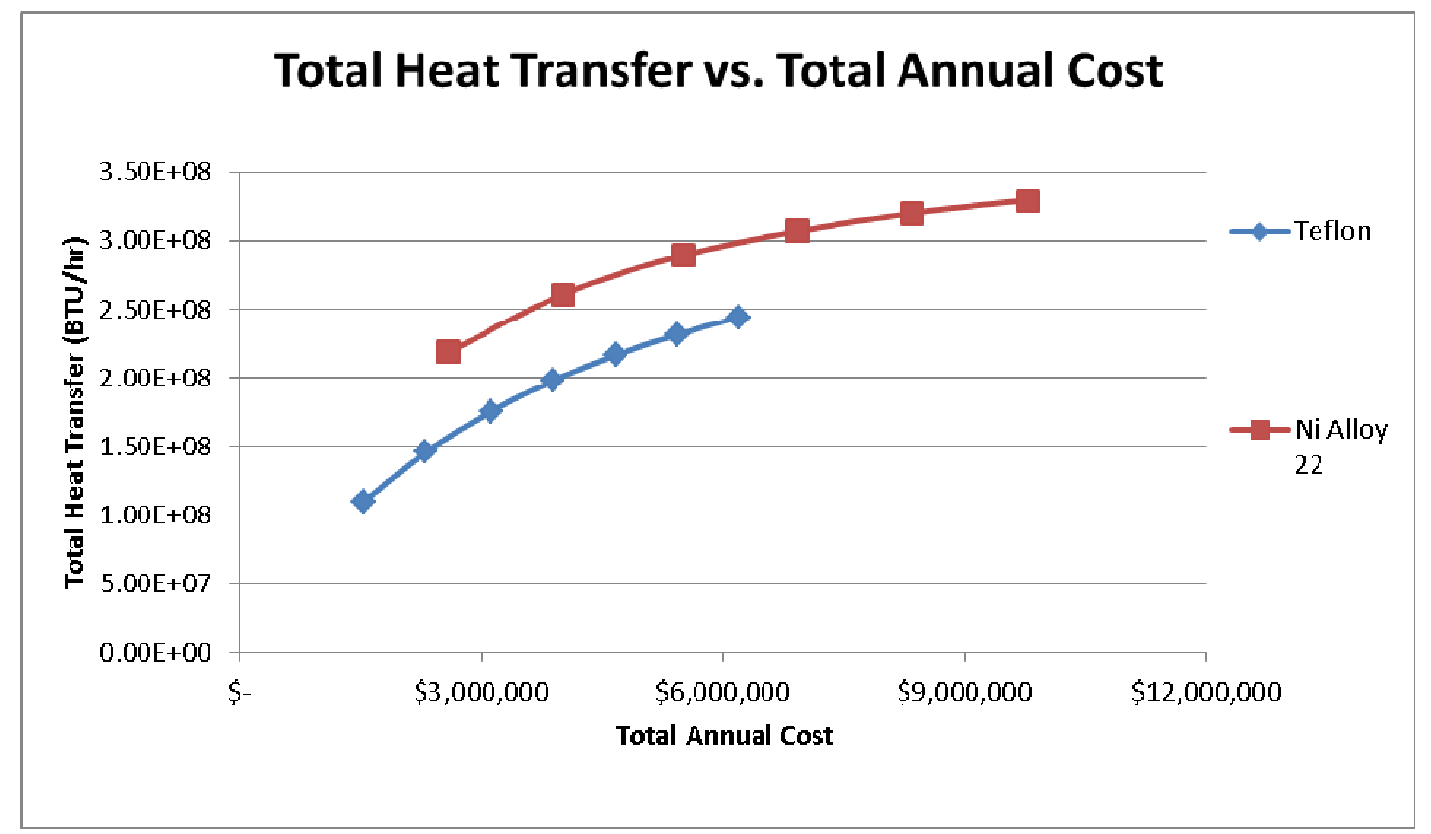

Figure 6-9: Total Heat Transfer vs. Annual Cost. Comparison of Teflon and Alloy 22 Heat Exchangers.

Heat Exchangers for $300^{\circ} \mathrm{F}$ and $135^{\circ} \mathrm{F}$ Inlet Gas Temperatures. There will be separate applications for condensing heat exchangers, depending on coal type. A boiler firing a Powder River Basin coal, with its typically low sulfur and high alkali contents, may not need a wet $\mathrm{SO}_{2}$ scrubber, and in this case, the flue gas temperature at the inlet of the condensing heat exchanger will be in the $300^{\circ} \mathrm{F}$ range with inlet water vapor concentrations of approximately 12 volume percent range. For those applications in which a wet FGD is needed for $\mathrm{SO}_{2}$ control (bituminous coals and some lignites typically require wet FGD's), the flue gas entering the condensing heat exchanger will be saturated with water vapor and have a temperature ranging from 125 to $135^{\circ} \mathrm{F}$, with the temperature depending on coal moisture content.

Design calculations were performed for heat exchangers with $300^{\circ} \mathrm{F}$ and $135^{\circ} \mathrm{F}$ inlet flue gas temperatures, and the corresponding capital and operating costs were estimated. In each case, an inlet flue gas flow rate of 6 million $\mathrm{lbm} / \mathrm{hr}$ and a cooling water to flue gas flow rate ratio of 0.5 were assumed. Inlet water temperatures from 90 to $105^{\circ} \mathrm{F}$ were assumed. Inlet flue gas water vapor concentrations of 12 volume percent for PRB coal and 17.2 volume percent for the wet FGD case were assumed. 
Figures 6-10 to 6-12 show predicted condensation rate, condensation efficiency and heat transfer rate as functions of inlet cooling water temperature and heat exchanger length (or equivalently, heat exchanger surface area) for a $300^{\circ} \mathrm{F}$ inlet flue gas temperature. These show the condensation process is particularly sensitive to cooling water temperature, with predicted condensation rate doubling as cooling water temperature decreases from 105 to $90^{\circ} \mathrm{F}$.

Rates of heat transfer and condensation and condensation efficiency also depend strongly on cooling water to flue gas flow rate ratio. Figure 6-13 shows predicted condensation efficiencies for a $300^{\circ} \mathrm{F}$ flue gas inlet temperature and for a $90^{\circ} \mathrm{F}$ inlet cooling water temperature and heat exchanger surface areas ranging up to $600,000 \mathrm{ft}^{2}$. The results show the condensation efficiency increases from approximately 17 to 60 percent as Mcw/Mfg increases from 0.5 to 2.0 for a heat exchanger with $600,000 \mathrm{ft}^{2}$ of surface area.

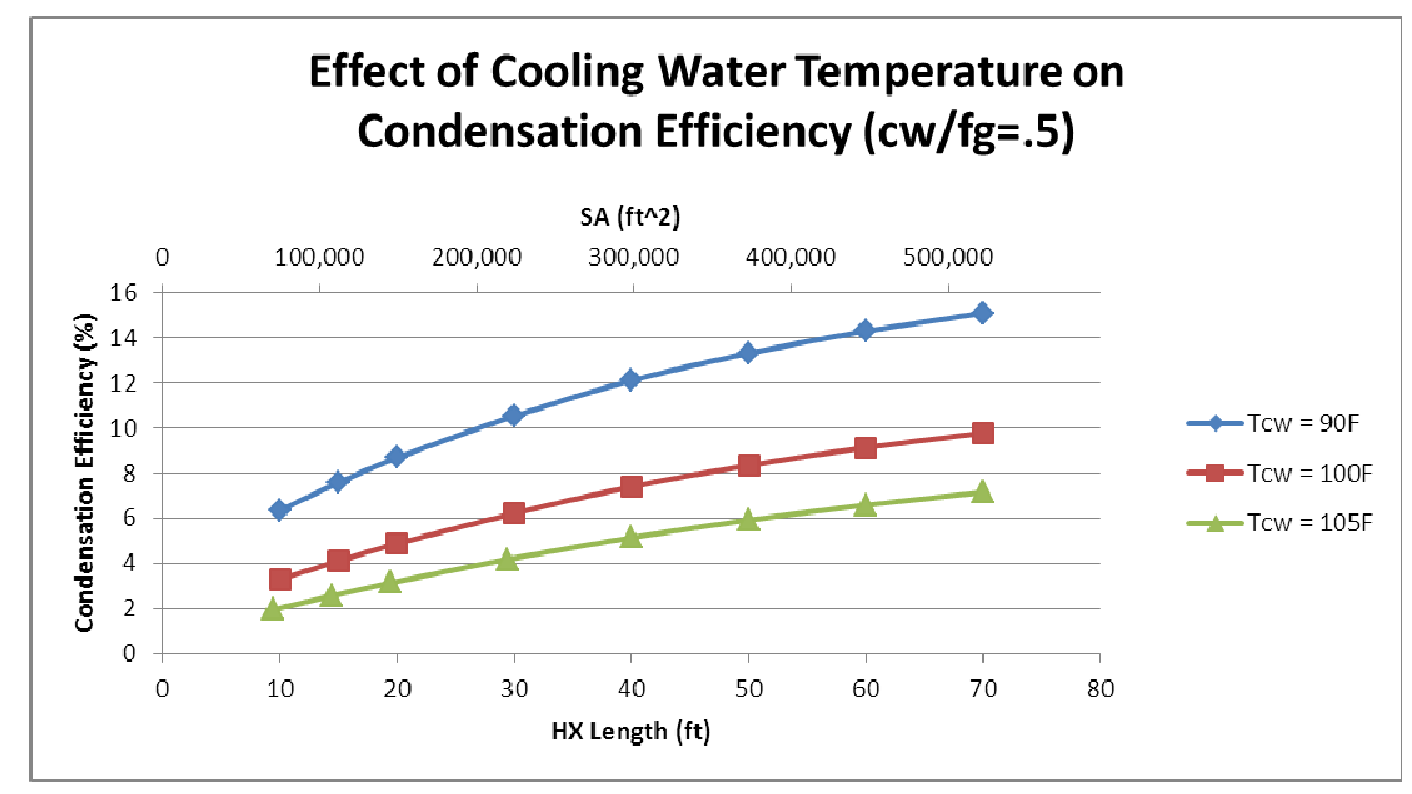

Figure 6-10: Condensation Efficiency vs. Heat Exchanger Size for $300^{\circ} \mathrm{F}$ Inlet Flue Gas Temperature. Effect of Inlet Cooling Water Temperature. 


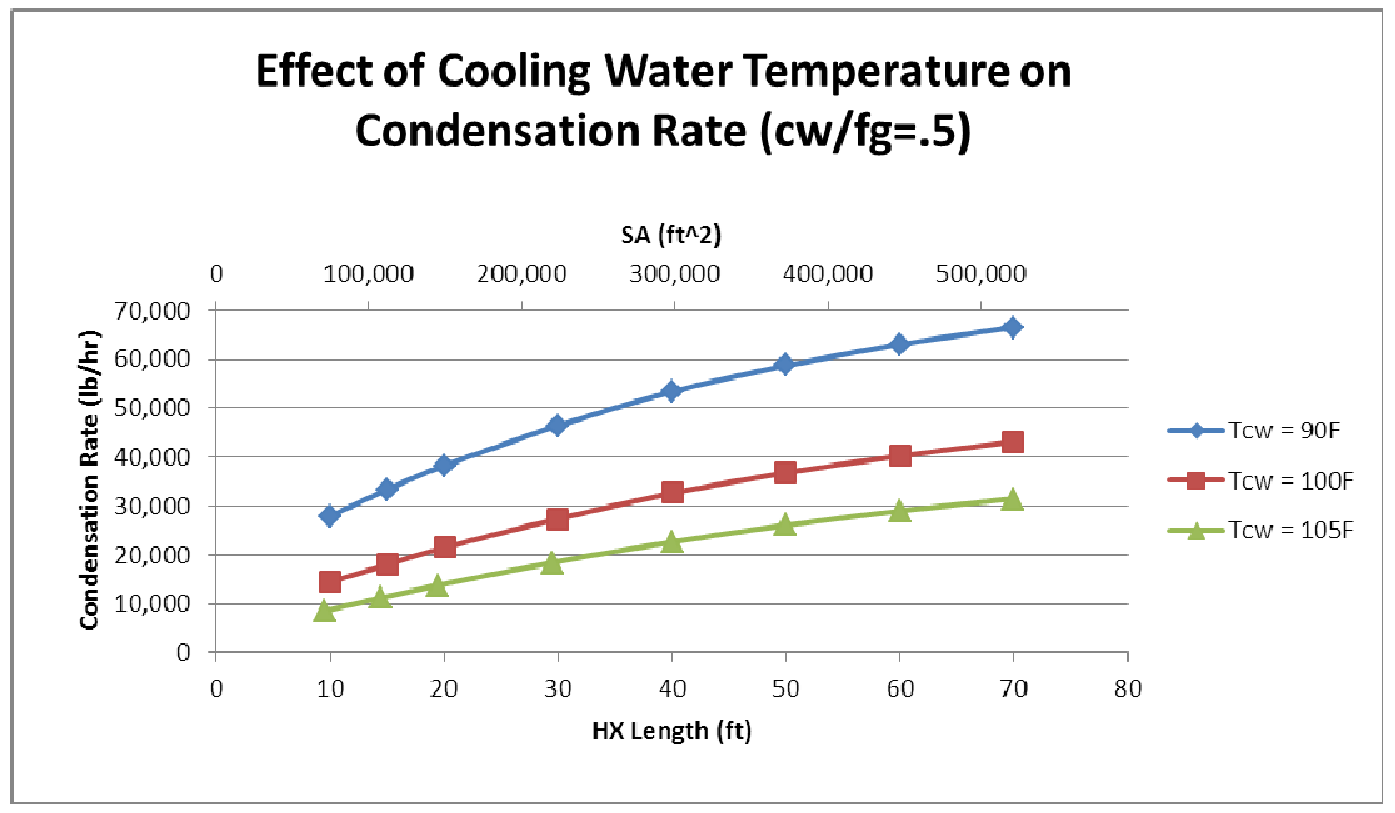

Figure 6-11: Condensation Rate vs. Heat Exchanger Size for $300^{\circ} \mathrm{F}$ Inlet Flue Gas Temperature. Effect of Inlet Cooling Water Temperature.

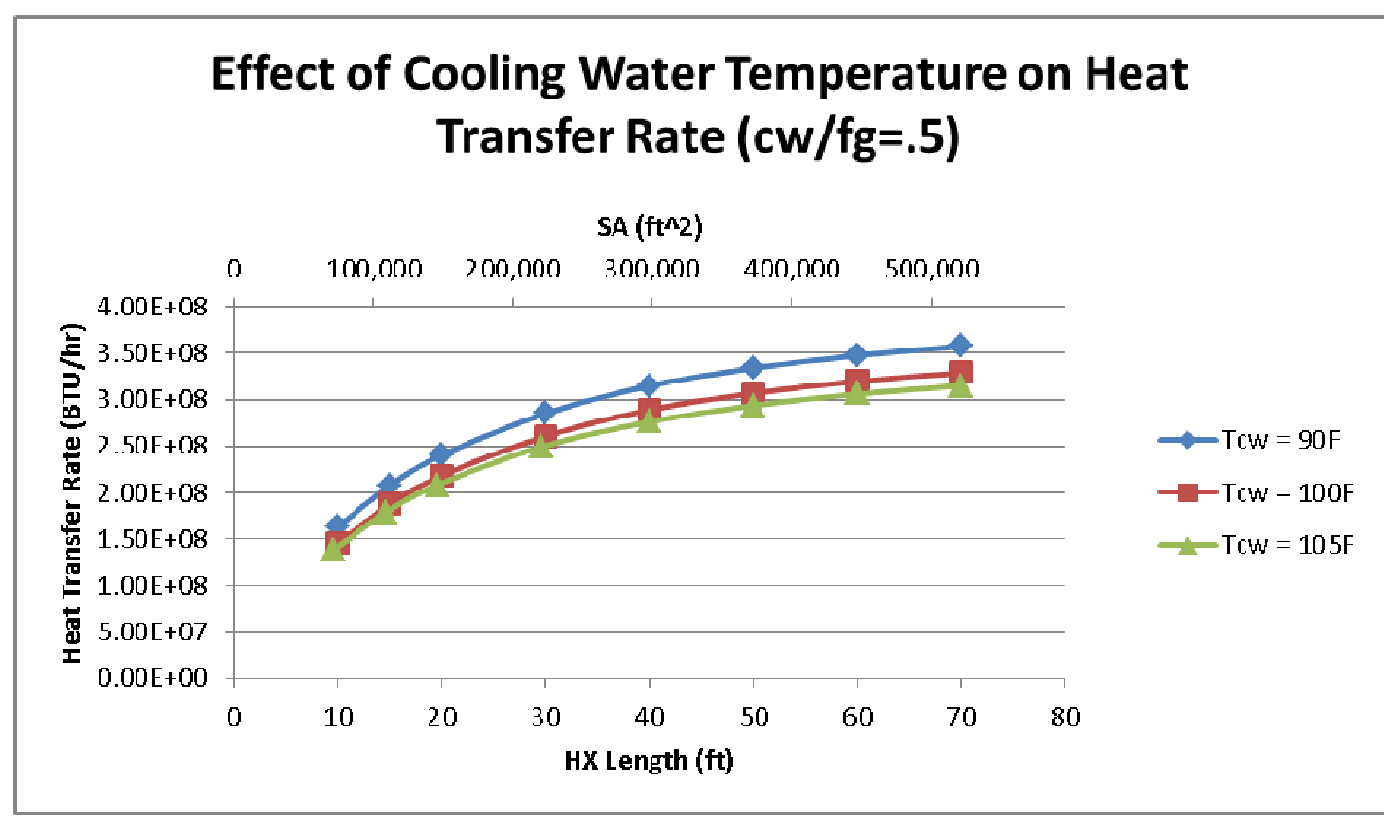

Figure 6-12: Heat Transfer Rate vs. Heat Exchanger Size for $300^{\circ} \mathrm{F}$ Inlet Flue Gas Temperature. Effect of Inlet Cooling Water Temperature. 


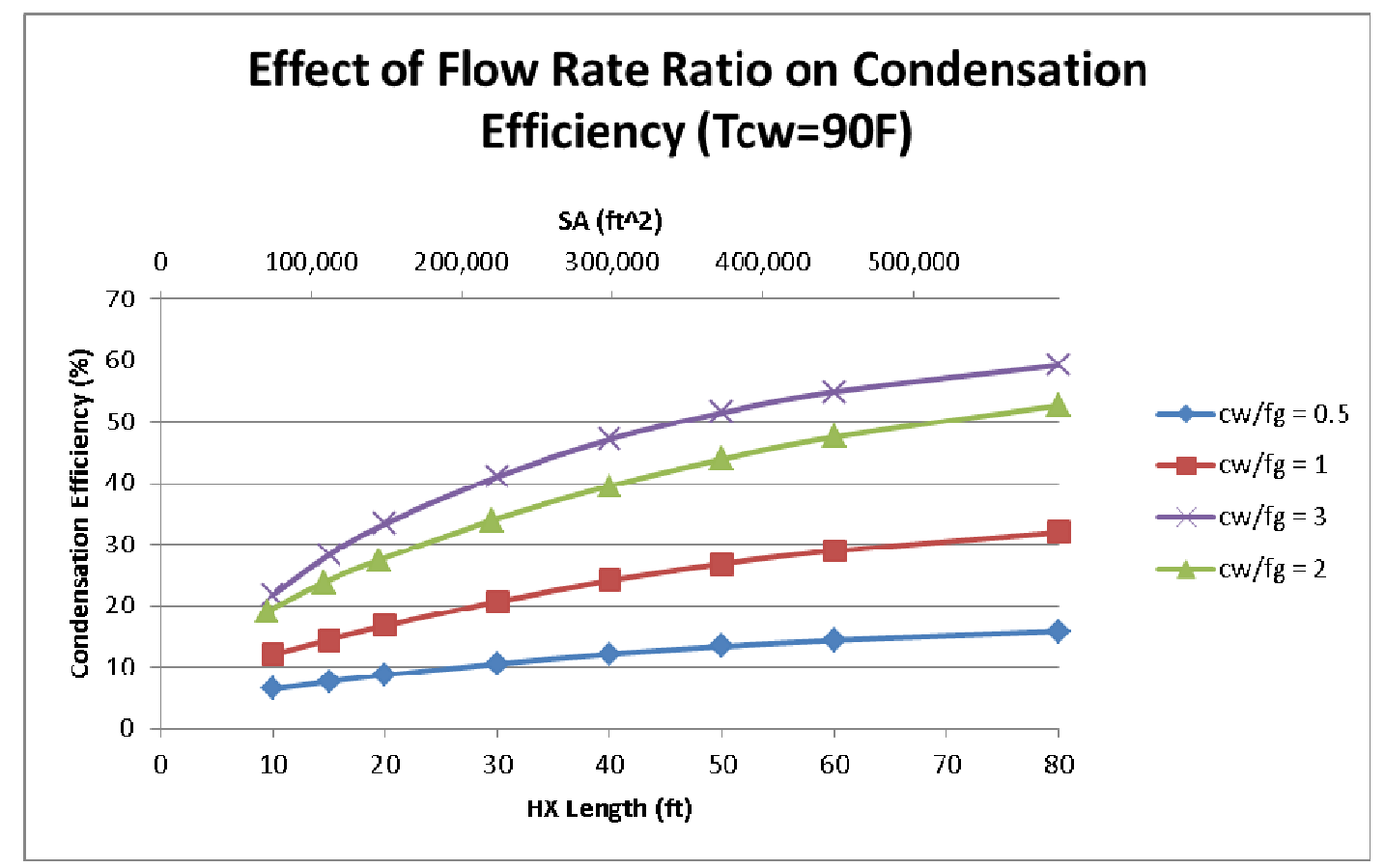

Figure 6-13: Condensation Efficiency vs. Heat Exchanger Size for $300^{\circ} \mathrm{F}$ Inlet Flue Gas Temperature. Effect of Cooling Water to Flue Gas Flow Rate Ratio.

Figures 6-14 to 6-17 show corresponding results for the $135^{\circ} \mathrm{F}$ inlet case. Because of a lower inlet flue gas temperature, heat exchangers for use after a wet FGD will have much smaller heat transfer surface areas, with correspondingly smaller flue gas and cooling water pressure drops. The comparisons between heat exchangers for 135 and $300^{\circ} \mathrm{F}$ inlet flue gas are shown more clearly in Figure 6-18 and Table 6-2.

The cost summary in Table 6-2 and condensation efficiency predictions in Figures $6-10$ and $6-14$ show that for the $135^{\circ} \mathrm{F}$ inlet case, there would be approximately 18 percent water capture, the heat exchanger installed costs would be $\$ 4.55$ million and total annual costs would be $\$ 602,000$. A $50 \mathrm{ft}$ long, $375,000 \mathrm{ft}^{2}$ heat exchanger for a $300^{\circ} \mathrm{F}$ inlet flue gas, would have an installed capital cost of $\$ 66$ million, $\$ 6.92$ million in total annual costs and would have a 14 percent water capture efficiency. 


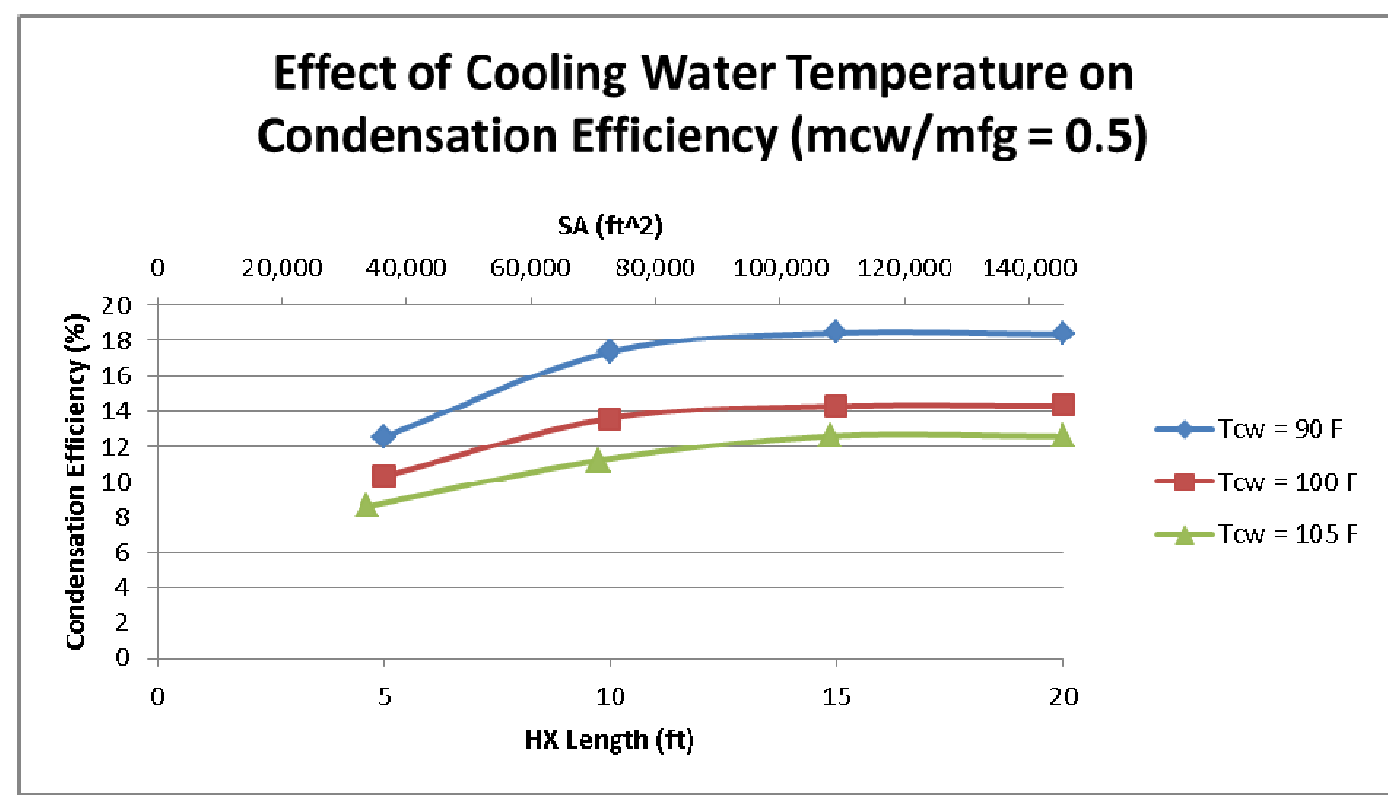

Figure 6-14: Condensation Efficiency vs. Heat Exchanger Size for $135^{\circ} \mathrm{F}$ Inlet Flue Gas Temperature. Effect of Inlet Cooling Water Temperature.

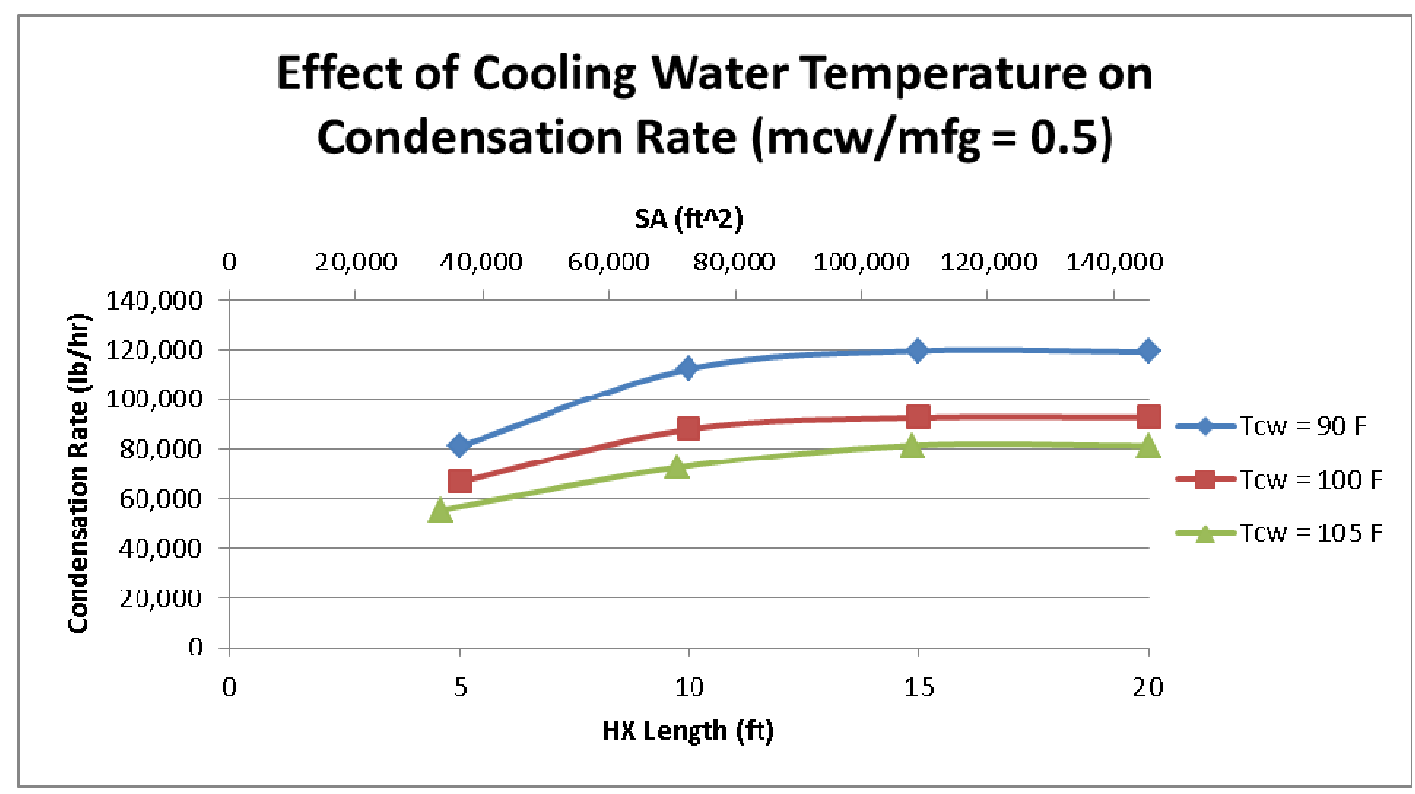

Figure 6-15: Condensation Rate vs. Heat Exchanger Size for $135^{\circ} \mathrm{F}$ Inlet Flue Gas Temperature. Effect of Inlet Cooling Water Temperature. 


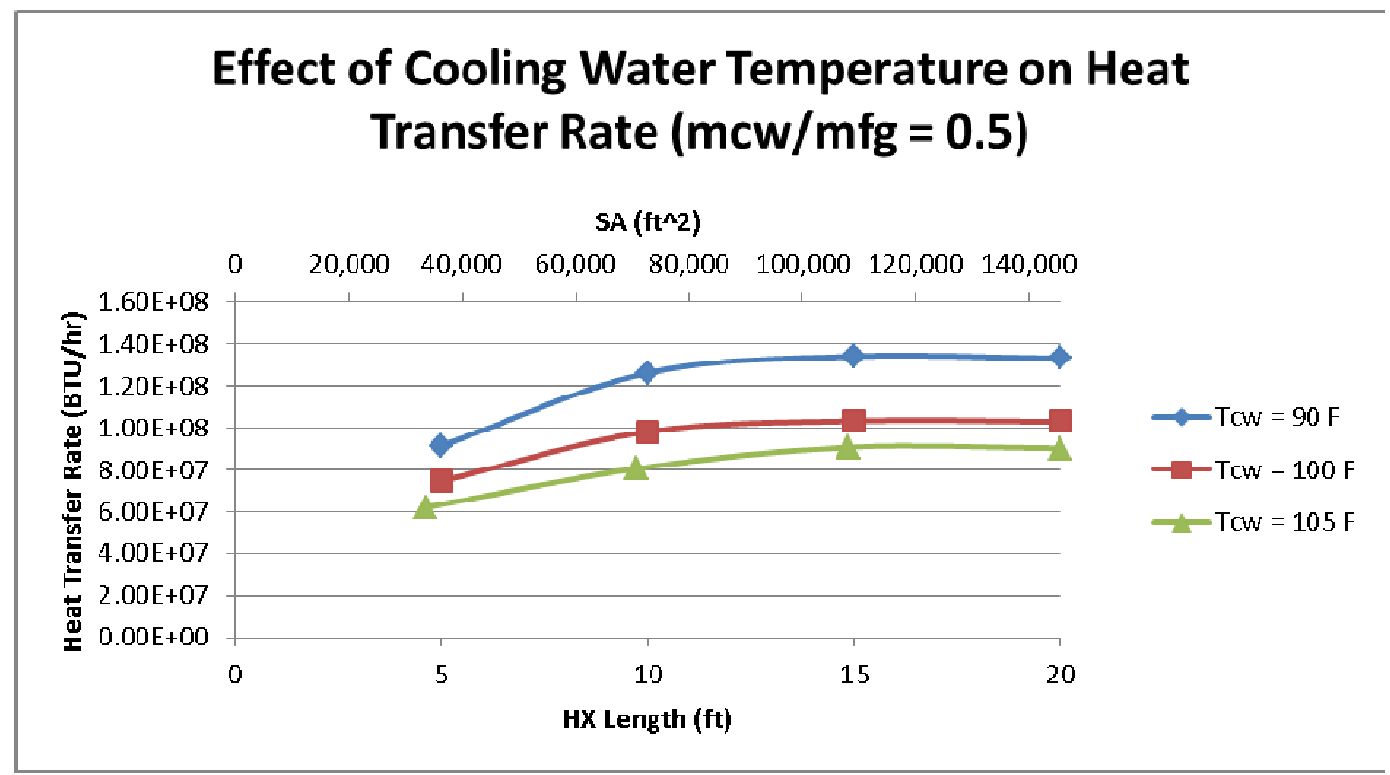

Figure 6-16: Heat Transfer Rate vs. Heat Exchanger Size for $135^{\circ} \mathrm{F}$ Inlet Flue Gas Temperature. Effect of Inlet Cooling Water Temperature.

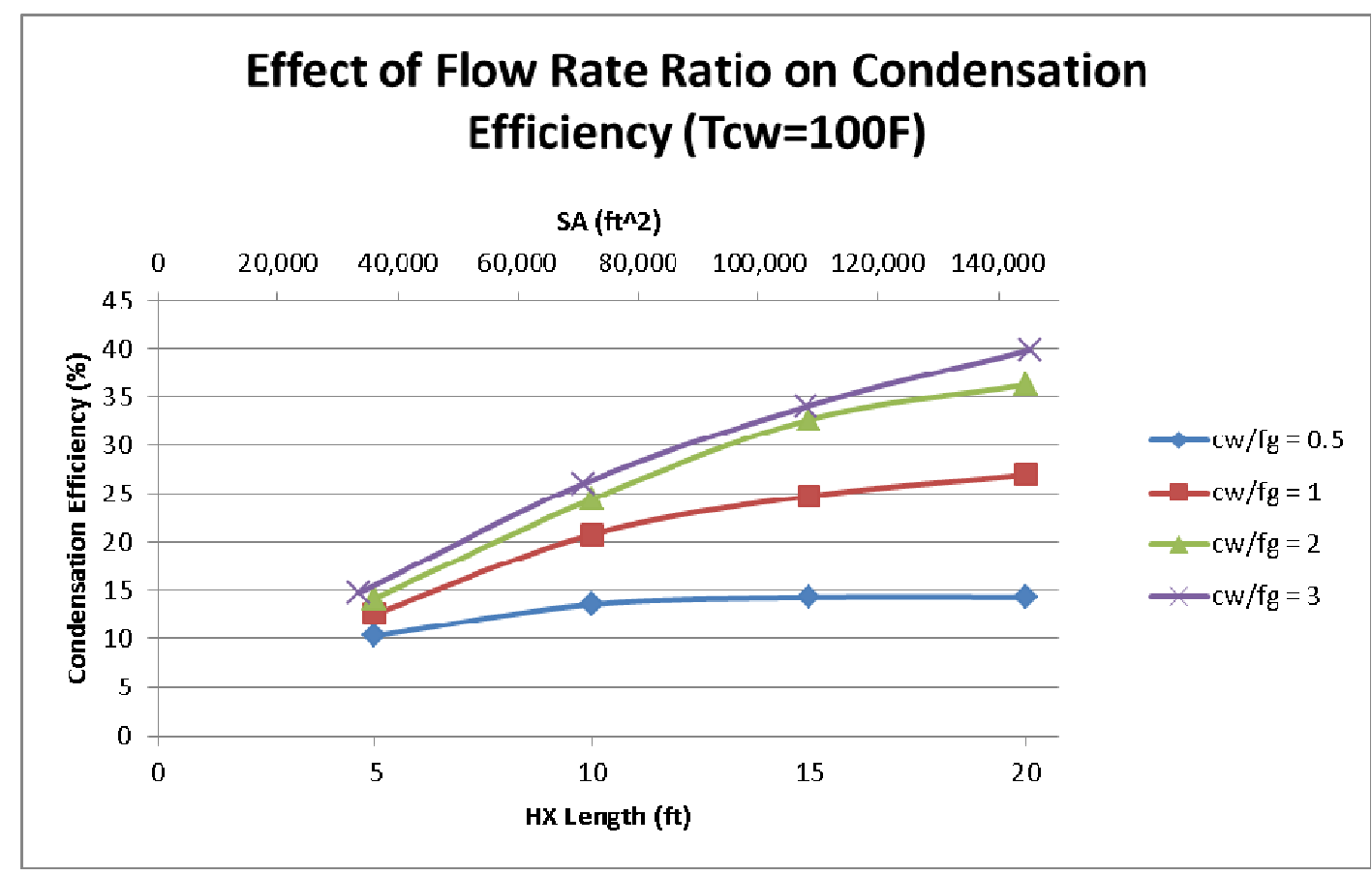

Figure 6-17: Condensation Efficiency vs. Heat Exchanger Size for $135^{\circ} \mathrm{F}$ Inlet Flue Gas Temperature. Effect of Cooling Water to Flue Gas Flow Rate Ratio. 


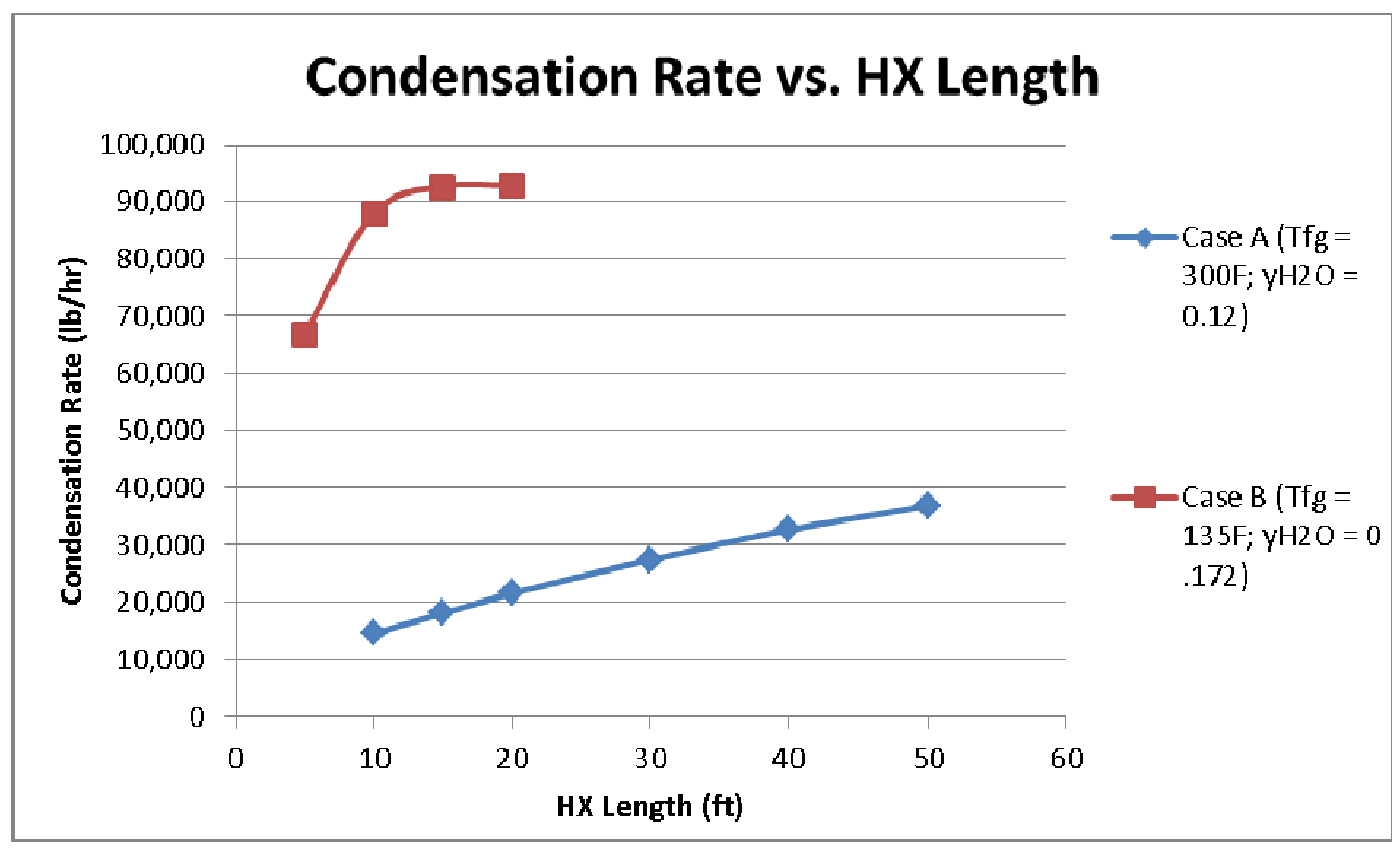

Figure 6-18: Performance Comparison of $135^{\circ} \mathrm{F}$ and $300^{\circ} \mathrm{F}$ Heat Exchangers.

Table 6-2: Predicted Heat Exchanger Costs and Condensation and Heat Transfer Rates vs. Heat Exchanger Length for $300^{\circ} \mathrm{F}$ and $135^{\circ} \mathrm{F}$ Inlet Flue Gas Temperatures and $90^{\circ} \mathrm{F}$ Inlet Cooling Water Temperature.

\begin{tabular}{|c|c|c|c|c|c|}
\hline & & $\mathrm{Tfg}=300 \mathrm{~F}$ & $; Y=0.12$ & & \\
\hline $\begin{array}{l}\text { Duct } \\
\text { Length }\end{array}$ & $\begin{array}{c}\text { Cond. } \\
\text { Rate }\end{array}$ & $\begin{array}{c}\text { Heat } \\
\text { Transfer }\end{array}$ & $\begin{array}{c}\text { Capital } \\
\text { Cost }\end{array}$ & $\begin{array}{c}\text { Annual } \\
\text { Operating } \\
\text { Cost }\end{array}$ & $\begin{array}{c}\text { Total } \\
\text { Annual } \\
\text { Cost } \\
\end{array}$ \\
\hline $\mathrm{ft}$ & $\mathrm{Ib} / \mathrm{hr}$ & Btu/hr & \$ Million & \$ Million & $\$$ Million \\
\hline 10 & $1.45 \mathrm{E}+04$ & $1.46 \mathrm{E}+08$ & 10.9 & 0.155 & 1.18 \\
\hline 15 & $1.80 \mathrm{E}+04$ & $1.88 \mathrm{E}+08$ & 17.6 & 0.229 & 1.89 \\
\hline 20 & $2.15 E+04$ & $2.19 \mathrm{E}+08$ & 24.3 & 0.301 & 2.59 \\
\hline 30 & $2.74 \mathrm{E}+04$ & $2.61 \mathrm{E}+08$ & 37.9 & 0.444 & 4.01 \\
\hline 40 & $3.27 E+04$ & $2.89 \mathrm{E}+08$ & 52.1 & 0.591 & 5.5 \\
\hline 50 & $3.68 \mathrm{E}+04$ & $3.07 \mathrm{E}+08$ & 65.7 & 0.729 & 6.92 \\
\hline & & $\mathrm{Tfg}=135 \mathrm{~F}$ & $; Y=0.172$ & & \\
\hline $\begin{array}{c}\text { Duct } \\
\text { Length }\end{array}$ & $\begin{array}{l}\text { Cond. } \\
\text { Rate }\end{array}$ & $\begin{array}{c}\text { Heat } \\
\text { Transfer }\end{array}$ & $\begin{array}{c}\text { Capital } \\
\text { Cost }\end{array}$ & $\begin{array}{c}\text { Annual } \\
\text { Operating } \\
\text { Cost }\end{array}$ & $\begin{array}{c}\text { Total } \\
\text { Annual } \\
\text { Cost } \\
\end{array}$ \\
\hline $\mathrm{ft}$ & $\mathrm{lb} / \mathrm{hr}$ & Btu/hr & \$ Million & \$ Million & \$ Million \\
\hline 5 & $6.68 \mathrm{E}+04$ & $7.50 \mathrm{E}+07$ & 1.7 & 0.067 & 0.229 \\
\hline 10 & $8.81 E+04$ & $9.80 \mathrm{E}+07$ & 3.6 & 0.138 & 0.478 \\
\hline 12.5 & $9.04 \mathrm{E}+04$ & $1.01 \mathrm{E}+08$ & 4.55 & 0.172 & 0.602 \\
\hline 15 & $9.27 \mathrm{E}+04$ & $1.03 E+08$ & 5.5 & 0.206 & 0.728 \\
\hline 20 & $9.28 \mathrm{E}+04$ & $1.03 \mathrm{E}+08$ & 7.2 & 0.276 & 0.951 \\
\hline
\end{tabular}




\section{Summary}

Because of its high corrosion resistance in dilute aqueous sulfuric acid solutions, relatively low cost and high tensile strength and thermal conductivity, 304 SS is the preferred choice for heat exchanger tubing at temperatures below the water vapor dew point.

At locations in the flue gas upstream of the water vapor dewpoint, the choice is between Teflon and Alloy 22. The relatively low thermal conductivity of Teflon would prevent water vapor condensation with Teflon tubes. In addition, while Teflon is the less expensive of the two materials per foot of tubing, it has extremely low values of thermal conductivity and tensile strength compared to Alloy 22. In order to transfer the same amount of heat, the Teflon heat exchanger would need to have approximately three times the surface area of an Alloy 22 heat exchanger, and this would also result in larger pump and fan power requirements than would be needed for the Alloy 22 heat exchanger. As a consequence, the total annual costs for a Teflon heat exchanger would be greater than for a heat exchanger fabricated from Alloy 22 .

There will be separate applications for condensing heat exchangers, depending on coal type. A boiler firing a Powder River Basin coal may not need a wet $\mathrm{SO}_{2}$ scrubber, and in this case, the flue gas temperature at the inlet of the condensing heat exchanger will be in the $300^{\circ} \mathrm{F}$ range with inlet water vapor concentrations of approximately 12 volume percent range. For those applications in which a wet FGD is needed for $\mathrm{SO}_{2}$ control (bituminous coals and some lignites typically require wet FGD's), the flue gas entering the condensing heat exchanger will be saturated with water vapor and have a temperature ranging from 125 to $135^{\circ} \mathrm{F}$, with the temperature depending on coal moisture content.

Because of a lower inlet flue gas temperature, heat exchangers for use after a wet FGD will have much smaller heat transfer surface areas, with correspondingly smaller flue gas and cooling water pressure drops. For the case analyzed here, there would be approximately 18 percent water capture, the heat exchanger installed costs 
would be $\$ 4.55$ million and total annual costs would be $\$ 602,000$ for a post-FGD heat exchanger installation. A condensing heat exchanger for $300^{\circ} \mathrm{F}$ inlet flue gas, would have an installed capital cost of at least $\$ 66$ million, at least $\$ 6.92$ million in total annual costs and a water capture efficiency of approximately 14 percent.

Results of heat exchanger performance calculations show the condensation process is particularly sensitive to cooling water temperature, with predicted condensation rate doubling as cooling water temperature decreases from 105 to $90^{\circ} \mathrm{F}$.

Rates of heat transfer and condensation and condensation efficiency also depend strongly on cooling water to flue gas flow rate ratio. For example, results for a $300^{\circ} \mathrm{F}$ flue gas inlet temperature and for a $90^{\circ} \mathrm{F}$ inlet cooling water temperature show the predicted condensation efficiency increasing from approximately 17 to 60 percent as $\dot{\mathrm{M}} \mathrm{cw} / \dot{\mathrm{M} f g}$ increases from 0.5 to 2.0 for a heat exchanger with $600,000 \mathrm{ft}^{2}$ of heat exchanger surface area.

As a consequence, if the heat exchangers are water cooled, the available cooling water flow rate and temperature will govern to some extent whether the heat exchangers are better suited for improving unit heat rate or recovering water vapor from flue gas for use as cooling tower makeup water. For applications in which water conservation is the principal concern, a likely source of cooling water will be cold boiler feedwater leaving the steam condenser. The flow rate of cold boiler feedwater is typically about one half of the flue gas flow rate of the unit and depending on time of year, the feedwater temperature typically ranges from 85 to $110^{\circ} \mathrm{F}$. Recovery of water vapor from flue gas can be enhanced through a combination of water and air-cooled heat exchangers.

For applications in which heat rate improvement is the principal concern, and sufficiently high flow rates of cooling water are available, the total rate of heat transfer can be increased significantly by operating the flue gas heat exchanger with cooling water-to-flue gas flow ratios which are larger than 0.5 and cooling water inlet temperatures which are lower than typical cold boiler feedwater temperatures. 


\section{Reference}

1. Jeong, K., M. Kessen, H. Bilirgen and E. Levy, "Analytical Modeling of Water Condensation in Condensing Heat Exchanger," International Journal of Heat and Mass Transfer, 53 (2010) 2361-2368. 


\section{CHAPTER 7}

\section{TREATMENT OF CONDENSED WATER FOR USE AS COOLING TOWER MAKEUP WATER}

\section{Introduction}

The slip stream tests described in Chapter 2 were carried out at three coal fired boilers using the test heat exchanger apparatus shown in Figure 7-1. In all tests, the pilot scale test apparatus was located downstream of the boiler's particulate control device. The total flue gas flow rate through the apparatus ranged from 300 to 1500 $\mathrm{lbm} / \mathrm{hr}$. For a $500 \mathrm{MW}$ coal-fired power plant, the actual flue gas flow rate is estimated to be about $6,000,000 \mathrm{lbm} / \mathrm{hr}$. Therefore, the ratio of the flue gas flow rate used in the pilot scale system to the actual flue gas flow rate in a $500 \mathrm{MW}$ power plant is in the range of $5 / 100,000$ to $25 / 100,000$.

Condensate samples were collected at the bottom of each heat exchanger section to determine the condensate flow rate and chemical composition of the collected water.

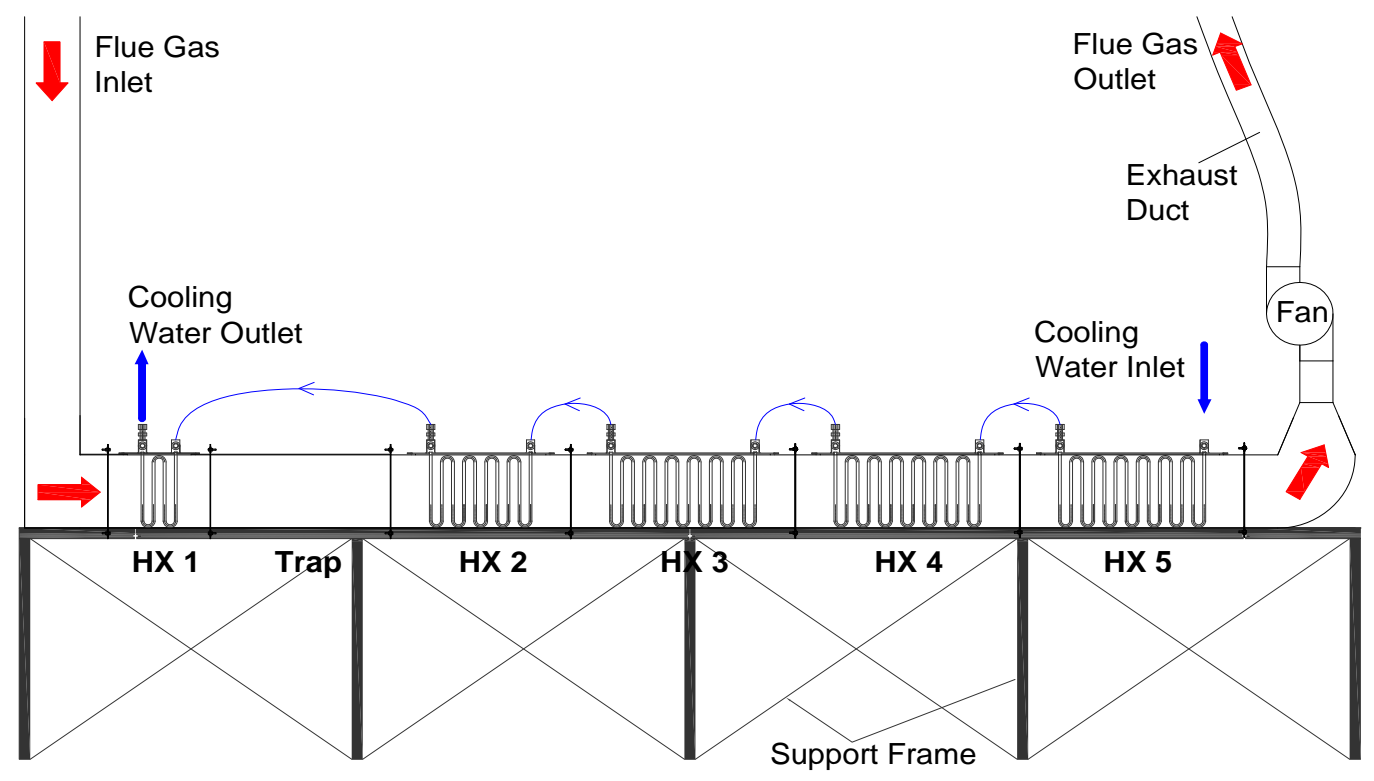

Figure 7-1: Condensing Heat Exchanger Test Apparatus - Water Recovery System (WRS). 
Table 7-1 summarizes the ranges of concentrations of impurities in the condensed water obtained from two of the coal-fired boilers (Units $A$ and $C$ ) and a oilfired boiler (Unit D). Table 7-2 illustrates the range of measured heavy metal concentrations obtained from two coal-fired boilers (Units B and C). Table 7-3 shows the estimated flow rates of impurities in condensed water for a $500 \mathrm{MW}$ coal-fired boiler for a range of flue gas conditions and heat exchanger capture efficiencies. According to these calculations, the estimated condensate flow rate for a $500 \mathrm{MW}$ boiler would range from about 8,000 to $30,000 \mathrm{gph}$. The corresponding flow rates of acids are shown in Table 7-3.

Water is used for a multitude of purposes in a fossil-fired power plant, including equipment cooling (cooling water), maintenance cleaning, air pollution control (scrubbing), solids conveying, and as the working fluid for the steam cycle. Cooling water includes the water used for condenser cooling in the turbine cycle heat rejection system and for the cooling of auxiliary equipment.

This Chapter examines the treatment costs for condensed water from flue gas, where the treated water is to be used as cooling tower makeup water. Two treatment options (ion exchange and reverse osmosis) were considered, with the ion exchange method being selected because of it's ability to provide levels of water purity consistent of the needs of cooling tower makeup water and at a substantially lower cost than treated water from a reverse osmosis system. While reverse Osmosis (RO) can be considered to be an alternative to ion exchange water treatment systems, RO systems are usually used for processes that require extremely high purity water. In addition, the capital investment and O\&M costs of the RO systems can be considerably higher than those for ion exchange systems. One of the disadvantages of the RO recovery systems is that they are subject to fouling without good prefiltration and $\mathrm{pH}$ adjustment. In addition, ion exchange systems can be designed to remove only the target ions from the effluent stream, which helps to reduce the capital and O\&M costs. 
Table 7-1: Ranges of Impurity Concentrations in Condensed Water

\begin{tabular}{|c|c|c|c|c|c|c|c|}
\hline & & Unit & & & $\mathrm{tC}$ & & it $D$ \\
\hline & Unit & rans & & & & & nge \\
\hline Avg moisture @ inlet & $\%$ & 12.5 & 13.2 & & 12.8 & & 10.9 \\
\hline H2O capture efficiency & $\%$ & 45 & 75 & 26 & 34 & 27 & 65 \\
\hline Total flue gas flow rate, DRY & $\mathrm{Ib} / \mathrm{hr}$ & 360 & 371 & 1000 & 1500 & 342 & 504 \\
\hline Water condensation rate & $\mathrm{Ib} / \mathrm{hr}$ & 13 & 24 & 22 & 37.5 & 9.5 & 23 \\
\hline Sulfate concentration in condensate & $\mathrm{mg} / \mathrm{L}$ & 5 & 450 & 10 & 1400 & 10 & 450 \\
\hline Chloride concentration & $\mathrm{mg} / \mathrm{L}$ & 10 & 170 & 15 & 15 & 2 & 27 \\
\hline Nitrate concentration & $\mathrm{mg} / \mathrm{L}$ & 0.3 & 22 & 10 & 10 & 0.1 & 5.6 \\
\hline Mercury concentration & $\mathrm{mg} / \mathrm{L}$ & 0.0008 & 0.0013 & & & & \\
\hline Calcium concentration & $\mathrm{mg} / \mathrm{L}$ & & & 0.2 & $\overline{5.1}$ & & \\
\hline
\end{tabular}

Table 7-2: Ranges of Heavy Metal Concentrations in Condensed Water

\begin{tabular}{|c|c|c|c|c|c|c|c|}
\hline Heavy Metals & & \multicolumn{2}{|c|}{ Unit A } & \multicolumn{2}{|c|}{ Unit C } & \multicolumn{2}{|c|}{ Unit B } \\
\hline Mercury & $\mathrm{mg} / \mathrm{L}$ & 0.0008 & 0.0013 & $<0.0002$ & 0.0003 & & \\
\hline Arsenic & $\mathrm{mg} / \mathrm{L}$ & & & $<0.025$ & $<0.025$ & & \\
\hline Boron & $\mathrm{mg} / \mathrm{L}$ & & & $<0.1$ & 2.11 & & \\
\hline Cadmium & $\mathrm{mg} / \mathrm{L}$ & & & $<0.001$ & $<0.001$ & & \\
\hline Chromium & $\mathrm{mg} / \mathrm{L}$ & & & $<0.001$ & 0.107 & & \\
\hline Selenium & $\mathrm{mg} / \mathrm{L}$ & & & $<0.04$ & 0.045 & & \\
\hline Bromide & $\mathrm{mg} / \mathrm{L}$ & & & $<0.05$ & 0.42 & & \\
\hline $\mathrm{Be}$ & ppb & & & & & 0.025 & 0.093 \\
\hline $\mathrm{Na}$ & $\mathrm{ppb}$ & & & & & 77.7 & 391.1 \\
\hline $\mathrm{Mg}$ & $\mathrm{ppb}$ & & & & & 80.3 & 440.1 \\
\hline $\mathrm{Al}$ & ppb & & & & & 268.3 & 2592.0 \\
\hline $\mathrm{K}$ & ppb & & & & & 30.1 & 200.0 \\
\hline $\mathrm{Ca}$ & ppb & & & & & 612.1 & 2175.0 \\
\hline $\mathrm{V}$ & $\mathrm{ppb}$ & & & & & 0.503 & 70.960 \\
\hline $\mathrm{Cr}$ & ppb & & & & & 286.76 & 8732.55 \\
\hline $\mathrm{Mn}$ & ppb & & & & & 16.79 & 1722.04 \\
\hline $\mathrm{Fe}$ & ppb & & & & & 2053.7 & 232841.7 \\
\hline Co & ppb & & & & & 0.738 & 40.783 \\
\hline $\mathrm{Ni}$ & $\mathrm{ppb}$ & & & & & 105.9 & 4962.1 \\
\hline $\mathrm{Cu}$ & $\mathrm{ppb}$ & & & & & 2.1 & 528.4 \\
\hline $\mathrm{Zn}$ & ppb & & & & & 58.7 & 12334.8 \\
\hline As & ppb & & & & & 0.065 & 1.516 \\
\hline $\mathrm{Se}$ & ppb & & & & & 11.93 & 80.82 \\
\hline Mo & ppb & & & & & 0.128 & 21.058 \\
\hline $\mathrm{Cd}$ & $\mathrm{ppb}$ & & & & & 0.014 & 0.255 \\
\hline $\mathrm{Ba}$ & ppb & & & & & 16.0 & 48.5 \\
\hline$\overline{T T}$ & ppb & & & & & 0.006 & 0.066 \\
\hline $\mathrm{Pb}$ & ppb & & & & & 0.698 & 11.426 \\
\hline
\end{tabular}


Table 7-3: Projected Ranges of Concentrations of Impurities in Condensed Water for a 500 MW Coal-fired Power Plant

\begin{tabular}{|c|c|c|c|c|}
\hline \multicolumn{5}{|c|}{ For a 500 MW-gross Coal-fired Boiler } \\
\hline Avg moisture @ inlet & $\%$ & & 11 & 11 \\
\hline $\mathrm{H} 2 \mathrm{O}$ capture efficiency & $\%$ & & 17 & 57 \\
\hline Total flue gas flow rate & $\mathrm{lb} / \mathrm{hr}$ & & $6,000,000$ & $6,000,000$ \\
\hline Water condensation rate, MAX & $\mathrm{Ib} / \mathrm{hr}$ & & $409,655.2$ & $409,655.2$ \\
\hline Water condensation rate, Eff & Ib/hr & & $69,641.4$ & $233,503.4$ \\
\hline Condensated water flow Rate & $\mathrm{ft} \wedge 3 / \mathrm{hr}$ & & $1,121.23$ & $3,759.41$ \\
\hline Condensated water flow Rate & L/hr & & $31,749.29$ & $106,453.50$ \\
\hline Condensated water flow Rate & gal/hr & & $8,387.30$ & $28,122.13$ \\
\hline \multirow[t]{2}{*}{ Condensated Sulfate flow rate } & Ibm/hr & Min & 4.6855 & 15.7101 \\
\hline & & Max & 194.48 & 652.09 \\
\hline \multirow[t]{2}{*}{ Condensated Chloride flow rate } & $\mathrm{lbm} / \mathrm{hr}$ & Min & 0.133 & 0.446 \\
\hline & & Max & 3.80 & 12.76 \\
\hline \multirow[t]{2}{*}{ Condensated Nitrate flow rate } & Ibm/hr & 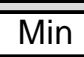 & 0.084 & 0.281 \\
\hline & & Max & 1.133 & 3.799 \\
\hline \multirow[t]{2}{*}{ Condensated Calcium flow rate } & $\mathrm{lbm} / \mathrm{hr}$ & 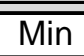 & 0.01399 & 0.04690 \\
\hline & & Max & 0.35666 & 1.19584 \\
\hline Sulfate concentration in condensate & $\mathrm{mg} / \mathrm{L}$ & & 67 & 2781 \\
\hline Chloride concentration in condensate & $\mathrm{mg} / \mathrm{L}$ & & 1.9 & 54.4 \\
\hline Nitrate concentration in condensate & $\mathrm{mg} / \mathrm{L}$ & & 1.2 & 16.2 \\
\hline Calcium concentration in condensate & $\mathrm{mg} / \mathrm{L}$ & & 0.2 & 5.1 \\
\hline
\end{tabular}

\section{Cooling Tower Makeup Water}

Cooling towers are heat-transfer units and are used as part of the condenser cooling system in the turbine cycle heat rejection system. The cooled water leaving a cooling tower is re-circulated (and thus, recycled) back to the condenser. Since the process water is re-circulated, the mineral concentration increases as a result of evaporation. When the water contains two times the original mineral content, it is said to contain two cycles of concentration. When it contains three times the original mineral content, it has three cycles of concentration and so on. The term "makeup", as defined in this report, refers specifically to an additional water supply for the circulating water used in a cooling tower and it should not be confused with makeup to the high purity water supply for steam/water cycle of fossil plant units.

The evaporation of water as the cooling flow is recirculated through the tower results in high concentrations of dissolved species. As these materials begin to reach 
solubility limits and the dissolved solids levels are increased, the potential for deposition, fouling, and corrosion of materials in the cooling circuit is dramatically increased. Blowdown is employed to limit the cooling water cycles of concentration to control the dissolved solids within prescribed control limits. Blowdown is also used to control the suspended solids in the circulating water and minimize the accumulation of sediments in the cooling tower basin.

The chemical composition of the cooling water is important from the standpoint of fill material selection. Scaling, corrosion and fouling are three common problems encountered on the heat transfer surfaces of cooling towers. All water contains some level of impurities which cause scale and corrosion in the heat exchanger equipment.

Problems caused by the impurities in cooling tower water system can be categorized into three classes; scaling, corrosion, and fouling.

Scaling - Most of the impurities in cooling water are alkaline, usually in the form of calcium bicarbonate and magnesium bicarbonate. The higher the concentrations of these impurities, the higher the $\mathrm{pH}$ level of the water. These impurities, especially calcium bicarbonate, are less soluble at higher $\mathrm{pH}$ values. Therefore, acid (usually sulfuric) is added to the circulating water to lower the $\mathrm{pH}$ value and increase the solubility of the impurities so they can be removed by system blow down. The $\mathrm{pH}$ of the circulating water should not fall below 6.0. If more acidic solutions are used, thorough rinsing is required to minimize any damage to galvanized surfaces.

$\mathrm{pH}$ is a measure of the acidity or alkalinity of a solution. Aqueous solutions at $25^{\circ} \mathrm{C}$ with a $\mathrm{pH}$ less than seven are considered acidic, while those with a $\mathrm{pH}$ greater than seven are considered basic (alkaline). When a pH level is 7.0, it is defined as 'neutral' at $25^{\circ} \mathrm{C}$ because at this $\mathrm{pH}$ the concentration of $\mathrm{H} 30+$ equals the concentration of $\mathrm{OH}$ - in pure water. 
Corrosion - Evaporation is the primary cooling effect of the tower, but as it occurs the concentration of salts in the water will increase. Only by disposing of a percentage of the re-circulated water and by adding fresh water to the cooling tower can the concentration of total dissolved solids (TDS) be kept under corrosive limits.

Corrosion can be minimized by the addition of a corrosion inhibitor, which is a chemical compound that stops or slows down corrosion of metals and alloys. Inhibitors are chemicals that react with a metallic surface, giving the surface a certain level of protection. This is done by relating inhibitor demand to the acid demand [4].

Fouling - Fouling occurs when suspended particles fall out of solution forming deposits. Common foulants include organic matter, process oils, and silt (fine dirt particles that blow into the tower system, or enter in the make-up water supply). Factors that lead to fouling are low water velocities, corrosion, and process leaks. Fouling deposits, similar to scale deposits, impede the heat exchange capabilities of the system by providing an insulating barrier to the system metallurgy. Fouling in the tower fill can plug film fill reducing the evaporative surface area, leading to lower thermal efficiency of the system [5].

\section{Water Analyses: Condensed (Captured) Water and Typical Makeup Water}

The water analysis results indicate that the condensed water may need to be purified prior to its introduction to the cooling tower water cycle. Table 7-4 lists chemical compositions of cooling tower water, cooling tower makeup water, and river water for several units. These show there are large variations in the chemical compositions of cooling tower water. The total dissolved iron, for instance, ranged from $0.115 \mathrm{mg} / \mathrm{L}$ to $0.923 \mathrm{mg} / \mathrm{L}$ among the cooling tower water samples. An average of 50 percent or more variation in the concentrations of impurities in cooling tower water seems to be typical. 
Table 7-5 compares the average values of water sample data presented in Table 7-4. Comparisons of chemistry among the water samples reveal that the condensed water is comparable with typical cooling tower water except for nitrate, sulfate, and iron. In particular, iron concentrations are several orders of magnitude higher than those in average cooling tower water. This unusually high iron level in the condensate is most likely due to corrosion occurring on the duct walls and possibly also on some tube surfaces in the slip stream heat exchanger apparatus. The duct walls were made from carbon steel, which corrodes very rapidly in a sulfuric acid environment. The heat exchanger tubes in the region of water vapor condensation were stainless steel, which also corrodes, but at a much lower rate than carbon steel. The authors believe that the iron level would be much lower than that shown in Table 7-5 if corrosion resistant materials were used in the heat exchangers. (Please see Chapter 4 for a discussion of corrosion rates of various candidate heat exchanger tube materials).

Nitrate and sulfate concentrations are higher in the condensate flow when compared to the cooling tower water. In addition, the acidity of the condensed water $(\mathrm{pH} \sim 4.72)$ is higher than that of typical makeup water $(\mathrm{pH} \sim 7.55)$ used in the cooling tower. The average $\mathrm{pH}$ value in the condensate flow was computed using four condensate samples collected from heat exchangers 1,2,3, and $4(H X 1, H X 2, H X 3$, and $\mathrm{HX} 4$ ) for two different flow conditions. The $\mathrm{pH}$ analyses were repeated two times. Therefore, the average $\mathrm{pH}$ value of 4.72 was obtained by taking the arithmetic average of 16 condensate samples.

\section{Condensed Water Treatment}

A number of treatment processes are applicable for circulating water makeup pretreatment. Based on a literature survey and discussions with scientists and engineers who specialize in water treatment technologies, the following processes are recommended to treat the condensed water collected by the heat exchangers (Figure 71) before its introduction to the cooling tower water cycle. The process diagram of the proposed water treatment system is illustrated in Figure 7-2. 
Table 7-4: Typical Cooling Tower Water, River Water, and Makeup
Water Analyses (Performed on Three Different Days)

\begin{tabular}{|c|c|c|c|c|c|c|c|c|c|c|c|c|c|}
\hline Field Sample ID & Units & Unit E1 & Unit E2 & Unit E & Unit E1 & Unit E2 & Unit E & Unit E1 & Unit E2 & Unit E & Unit F & Unit G & Unit H \\
\hline & & $\begin{array}{l}\text { Cooling } \\
\text { Tower }\end{array}$ & $\begin{array}{l}\text { Cooling } \\
\text { Tower }\end{array}$ & $\begin{array}{l}\text { River } \\
\text { Water }\end{array}$ & $\begin{array}{l}\text { Cooling } \\
\text { Tower }\end{array}$ & $\begin{array}{l}\text { Cooling } \\
\text { Tower }\end{array}$ & $\begin{array}{c}\text { River } \\
\text { Water }\end{array}$ & $\begin{array}{l}\text { Cooling } \\
\text { Tower }\end{array}$ & $\begin{array}{l}\text { Cooling } \\
\text { Tower }\end{array}$ & $\begin{array}{l}\text { River } \\
\text { Water }\end{array}$ & $\begin{array}{l}\text { Cooling } \\
\text { Tower }\end{array}$ & $\begin{array}{c}\text { Makeup } \\
\text { Water }\end{array}$ & River Water \\
\hline Date & & \multicolumn{3}{|c|}{$8 / 26 / 2010$} & \multicolumn{3}{|c|}{$10 / 8 / 2010$} & \multicolumn{3}{|c|}{$11 / 3 / 2010$} & $2 / 28 / 2005$ & $4 / 10 / 2005$ & $12 / 12 / 2007$ \\
\hline Conductivity - Lab & umhos $/ \mathrm{cm}$ & 861 & 826 & 312 & 776 & 859 & 160 & 216 & 872 & 667 & 98 & 96 & \\
\hline pH Lab & & 7.37 & 7.59 & 7.65 & 7.8 & 8.05 & 7.38 & 7.74 & 7.98 & 7.99 & & 7.18 & 7.23 \\
\hline Ammonia Nitrogen & $\mathrm{mg} / \mathrm{L}$ & 0.05 & 0.04 & 0.03 & 0.05 & 0.09 & 0.03 & 0.07 & 0.08 & 0.07 & 0.11 & 0.36 & 0.4 \\
\hline Calcium, Dissolved, ICP & $\mathrm{mg} / \mathrm{L}$ & 79.8 & 81.8 & 28.6 & 71.6 & 84.6 & 15.1 & 21.4 & 86.4 & 65.5 & & & \\
\hline Calcium, Total, ICP & $\mathrm{mg} / \mathrm{L}$ & 79.0 & 81.4 & 27.7 & 73.9 & 84.4 & 15.1 & 21.4 & 87 & 65.7 & $\begin{array}{c}\text { not } \\
\text { detected }\end{array}$ & 8.16 & 20.1 \\
\hline Magnesium, Dissolved, ICP & $\mathrm{mg} / \mathrm{L}$ & 30.3 & 31.1 & 10.5 & 24.9 & 29.5 & 4.93 & 6.78 & 30.5 & 23.2 & & & \\
\hline Magnesium, Total, ICP & $\mathrm{mg} / \mathrm{L}$ & 30.1 & 31.0 & 10.5 & 25.5 & 29.5 & 4.99 & 6.85 & 30.8 & 23.3 & 2.03 & 4.22 & 5.71 \\
\hline Sodium, Dissolved & $\mathrm{mg} / \mathrm{L}$ & 33.8 & 32.0 & 9.48 & 40.5 & 43.1 & 5.56 & 6.66 & 38.1 & 27.2 & & & \\
\hline Sodium, Total & $\mathrm{mg} / \mathrm{L}$ & 33.7 & 32.0 & 9.66 & 41.3 & 43.1 & 5.61 & 6.73 & 38.5 & 27.4 & 7.18 & 2.94 & 28.2 \\
\hline Potassium, Dissolved & $\mathrm{mg} / \mathrm{L}$ & 4.38 & 4.45 & 1.52 & 5.81 & 6.92 & 1.32 & 1.7 & 6.16 & 4.69 & & & \\
\hline Potassium, Total & $\mathrm{mg} / \mathrm{L}$ & 4.37 & 4.46 & 1.54 & 6.04 & 6.88 & 1.33 & 1.77 & 6.3 & 4.67 & 0.038 & 2.06 & 2.87 \\
\hline PHT Alkalinity & $\mathrm{mg} / \mathrm{L}$ & 0 & 0 & 0 & 0 & 0 & 0 & 0 & 0 & 0 & & & \\
\hline Total Alkalinity & $\mathrm{mg} / \mathrm{L}$ & 34.0 & 27.5 & 41.3 & 40.0 & 53 & 26 & 35.1 & 45 & 44 & 26 & 24.2 & 77.3 \\
\hline Chloride & $\mathrm{mg} / \mathrm{L}$ & 55.6 & 50.7 & 16.1 & 60.8 & 64.9 & 8.17 & 12 & 64.2 & 47 & 7.41 & 2.65 & 16.5 \\
\hline Nitrate as $\mathrm{NO} 3$ & $\mathrm{mg} / \mathrm{L}$ & 5.59 & 5.74 & 2.54 & 7.2 & 8.23 & 1.9 & 1.05 & 4.95 & 3.7 & & & \\
\hline Total phosphorus as $\mathrm{P}$ & $\mathrm{mg} / \mathrm{L}$ & & & & & & & & & & $\begin{array}{c}\text { not } \\
\text { detected }\end{array}$ & 0.01 & 0.06 \\
\hline Sulfate & $\mathrm{mg} / \mathrm{L}$ & 316 & 305 & 78.5 & 240 & 272 & 33.9 & 50.5 & 315 & 231 & 7.85 & 12.6 & 20.3 \\
\hline Silica (C) & ppm & 5.80 & 5.50 & 1.75 & 14.00 & 15.60 & 4.41 & 1.73 & 8.13 & 6.46 & & & \\
\hline Iron, Dissolved, ICP & $\mathrm{mg} / \mathrm{L}$ & 0.131 & 0.046 & 0.025 & 0.214 & 0.239 & 0.054 & 0.028 & 0.125 & 0.107 & & & \\
\hline Iron, Total, ICP & $\mathrm{mg} / \mathrm{L}$ & 0.297 & 0.184 & 0.059 & 0.814 & 0.923 & 0.211 & 0.319 & 0.499 & 0.435 & 0.115 & 0.099 & 0.162 \\
\hline Aluminum, Dissolved, ICP & $\mathrm{ug} / \mathrm{L}$ & 10.6 & 32.9 & 5.46 & 60.6 & 65.7 & 24.8 & 5.72 & 24.4 & 28.2 & & & \\
\hline Aluminum, Total, ICP & $\mathrm{ug} / \mathrm{L}$ & 56.6 & 97.1 & 32.4 & 274 & 273 & 99.1 & 103 & 149 & 135 & 0.097 & 0.021 & 0.112 \\
\hline Copper, Dissolved, ICP & $\mathrm{ug} / \mathrm{L}$ & 7.84 & 7.89 & 4.32 & 16.1 & 14 & 3.81 & -1.21 & 9.06 & 4.42 & & & \\
\hline Copper, Total, ICP & $\mathrm{ug} / \mathrm{L}$ & 8.92 & 15.5 & 3.18 & 24.3 & 108 & 5.78 & -3.06 & 16.4 & 18.7 & $\begin{array}{c}\text { not } \\
\text { detected }\end{array}$ & 0.024 & \\
\hline Manganese, Dissolved, ICP & $\mathrm{ug} / \mathrm{L}$ & 8.07 & 8.78 & 1.71 & 17 & 26.9 & 10.5 & 4.6 & 5.66 & 5.52 & & & \\
\hline Manganese, Total, ICP & $\mathrm{ug} / \mathrm{L}$ & 132 & 108 & 64.3 & 273 & 246 & 129 & 68.4 & 118 & 103 & 0.011 & 0.021 & \\
\hline Nickel, Dissolved, ICP & $\mathrm{ug} / \mathrm{L}$ & 1.32 & 1.83 & 1.56 & 5.33 & 6.47 & 8.16 & 1.28 & 2.41 & 4.52 & & & \\
\hline Nickel, Total, ICP & $\mathrm{ug} / \mathrm{L}$ & 1.62 & 3.68 & 0.407 & 5.41 & 10.4 & 3.78 & 2.19 & 3.51 & 5.66 & $\begin{array}{c}\text { not } \\
\text { detected }\end{array}$ & $\begin{array}{c}\text { not } \\
\text { detected }\end{array}$ & \\
\hline Zinc, Dissolved, ICP & $\mathrm{ug} / \mathrm{L}$ & 4.52 & 18.3 & 9.81 & 6.07 & 7.09 & 20 & -2.55 & -1.29 & 1.36 & & & \\
\hline Zinc, Total, ICP & $\mathrm{ug} / \mathrm{L}$ & 7.31 & 30.1 & 4.04 & 6.08 & 32 & 1.01 & -5.33 & 0.073 & 20.1 & $\begin{array}{c}\text { not } \\
\text { detected } \\
\end{array}$ & $\begin{array}{c}\text { not } \\
\text { detected }\end{array}$ & \\
\hline Total Suspended Solids & $\mathrm{mg} / \mathrm{L}$ & 4.29 & 3.43 & 3.38 & 11 & 10 & 2.2 & 6.4 & 10.5 & 8 & 53 & 60 & \\
\hline
\end{tabular}


Table 7-5: Comparisons of Water Compositions on Average Basis Typical Cooling Tower Water, Cooling Tower Makeup Water and Condensed Water

\begin{tabular}{|c|c|c|c|c|}
\hline Field Sample ID & Units & Cooling Tower & Cooling Tower & Condensate \\
\hline & & Water & Makeup Water & Water \\
\hline Date & & Average & Average & Average \\
\hline Conductivity - Lab & umhos/cm & 644.00 & 308.75 & \\
\hline pH Lab & & 7.76 & 7.55 & 4.72 \\
\hline Ammonia Nitrogen & $\mathrm{mg} / \mathrm{L}$ & 0.07 & 0.12 & \\
\hline Calcium, Dissolved, ICP & $\mathrm{mg} / \mathrm{L}$ & 70.93 & 36.40 & \\
\hline Calcium, Total, ICP & $\mathrm{mg} / \mathrm{L}$ & 71.18 & 29.17 & 2.650 \\
\hline Magnesium, Dissolved, ICP & $\mathrm{mg} / \mathrm{L}$ & 25.51 & 12.88 & \\
\hline Magnesium, Total, ICP & $\mathrm{mg} / \mathrm{L}$ & 22.25 & 10.75 & 0.260 \\
\hline Sodium, Dissolved & $\mathrm{mg} / \mathrm{L}$ & 32.36 & 14.08 & \\
\hline Sodium, Total & $\mathrm{mg} / \mathrm{L}$ & 28.93 & 11.40 & 0.234 \\
\hline Potassium, Dissolved & $\mathrm{mg} / \mathrm{L}$ & 4.90 & 2.51 & \\
\hline Potassium, Total & $\mathrm{mg} / \mathrm{L}$ & 4.27 & 2.40 & 0.115 \\
\hline Total Alkalinity & $\mathrm{mg} / \mathrm{L}$ & 37.23 & 33.88 & \\
\hline Chloride & $\mathrm{mg} / \mathrm{L}$ & 45.09 & 18.48 & 28.150 \\
\hline Nitrate as NO3 & $\mathrm{mg} / \mathrm{L}$ & 5.46 & 2.71 & 8.700 \\
\hline Sulfate & $\mathrm{mg} / \mathrm{L}$ & 215.19 & 89.00 & 1424 \\
\hline Silica (C) & ppm & 8.46 & 4.21 & \\
\hline Iron, Dissolved, ICP & $\mathrm{mg} / \mathrm{L}$ & 0.13 & 0.06 & \\
\hline Iron, Total, ICP & $\mathrm{mg} / \mathrm{L}$ & 0.45 & 0.20 & 117.4 \\
\hline Aluminum, Dissolved, ICP & $\mathrm{ug} / \mathrm{L}$ & 33.32 & 19.49 & \\
\hline Aluminum, Total, ICP & $\mathrm{ug} / \mathrm{L}$ & 136.11 & 66.63 & 1.430 \\
\hline Copper, Dissolved, ICP & $\mathrm{ug} / \mathrm{L}$ & 8.95 & 4.18 & \\
\hline Copper, Total, ICP & $\mathrm{ug} / \mathrm{L}$ & 28.34 & 6.92 & 0.265 \\
\hline Manganese, Dissolved, ICP & $\mathrm{ug} / \mathrm{L}$ & 11.84 & 5.91 & \\
\hline Manganese, Total, ICP & $\mathrm{ug} / \mathrm{L}$ & 135.06 & 74.08 & 0.869 \\
\hline Nickel, Dissolved, ICP & $\mathrm{ug} / \mathrm{L}$ & 3.11 & 4.75 & \\
\hline Nickel, Total, ICP & $\mathrm{ug} / \mathrm{L}$ & 4.47 & 3.28 & 2.534 \\
\hline Zinc, Dissolved, ICP & $\mathrm{ug} / \mathrm{L}$ & 5.36 & 10.39 & \\
\hline Zinc, Total, ICP & $\mathrm{ug} / \mathrm{L}$ & 11.71 & 8.38 & 6.197 \\
\hline Total Suspended Solids & $\mathrm{mg} / \mathrm{L}$ & 14.09 & 18.40 & \\
\hline
\end{tabular}

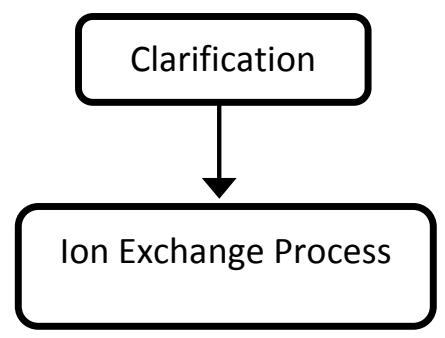

Figure 7-2: Proposed Water Treatment Process for the Condensate Water

Although the heat exchanger system would be located downstream of particulate collection devices (ESP or bag house), which remove the majority of dust particles from flue gas, very small amounts of dust particles were observed in the captured water at 
the bottom of the heat exchangers. Therefore, a particulate (suspended solid) filtering or removal system is recommended as the first step in the process.

Filtration (sometimes referred to as clarification) can be used to reduce total suspended solids (TSS), and, in some cases, organics, but it does not reduce levels of dissolved species such as calcium, magnesium, and silica. Reduction of TSS reduces the potential for settling of solids in the circulating water system. This improves maintainability and availability because the fouling of heat transfer surfaces and the contributions to microbiological attack decrease as the amount of sediment accumulation is reduced.

As an alternate to a clarification system, filter systems can be used as pretreatment options for TSS control. Particle filters function to remove suspended solids, organics, and silt particles down to 0.45 microns from a portion or all of the system water on a continual basis, thereby reducing fouling, and scaling.

In general, water softening is a necessary step to remove hardness (calcium and magnesium) from makeup water. This effectively manages (or eliminates) the amount of calcium and magnesium in the tower bulk water, thereby reducing the scaling potential of calcium and magnesium related deposits. However, this step (softening) does not seem to be necessary for the treatment of condensed water since both calcium and magnesium concentrations were low in the condensed water.

For high $\mathrm{pH}$ level make up water, acid treatment with sulfuric, hydrochloric, or ascorbic acid is used to improve the efficiency of a cooling system by controlling the scale buildup potential from mineral deposits. However, the $\mathrm{pH}$ level of the condensed water is very low (acidic solution) in this application, which is probably due to high concentrations of sulfate and nitrate in the condensed water. An ion exchange system can remove sulfate and nitrate ions, which will cause an increase in the $\mathrm{pH}$ level of the condensed water to levels which are compatible with the composition of typical makeup water, as illustrated in Table 7-5. Ion exchange will be the main treatment system for 
the condensed water preparation for the cooling tower. The following section discusses the details of a typical ion exchange water treatment system.

\section{Ion Exchange System}

Ion exchange and adsorption processes are used to remove dissolved ions and other charged species from water. Ion exchange processes are reversible chemical reactions that remove dissolved ions from solution and replace them with other similarly charged ions [1]. As water flows through a bed of ion exchange material, undesirable ions are removed and replaced with less objectionable ones (Figure 7-3). For example, in softening processes, calcium and magnesium ions (hardness) are exchanged for sodium ions. In dealkalization, the ions contributing to alkalinity (carbonate, bicarbonate, etc.) are removed and replaced with chloride ions. Other dealkalization processes utilizing weak acid cation resin or strong acid cation resin in a split stream process, exchange cations with hydrogen. This forms carbonic acid which can be removed in a decarbonator tower. Demineralization is simply replacing all cations with hydrogen ions $(\mathrm{H}+)$ and all anions with hydroxide ions $(\mathrm{OH}-)$. Ion exchange materials are like storage batteries; they must be recharged (regenerated) periodically to restore their exchange capacity [2]. With proper design and operation, ion exchange processes are capable of removing selected ions almost completely (in some cases to a fraction of a part per million).

In water treatment, the most common ion exchange process is cation exchange softening in which calcium and magnesium are removed. Anion exchange processes can be used for the removal of contaminants such as nitrate, fluoride, perchlorate, uranium, selenium, arsenic, sulfate, and natural organic matter (NOM), as well as others. Adsorption processes, such as activated alumina and granular ferric hydroxide, are used to remove arsenic and similar species. 


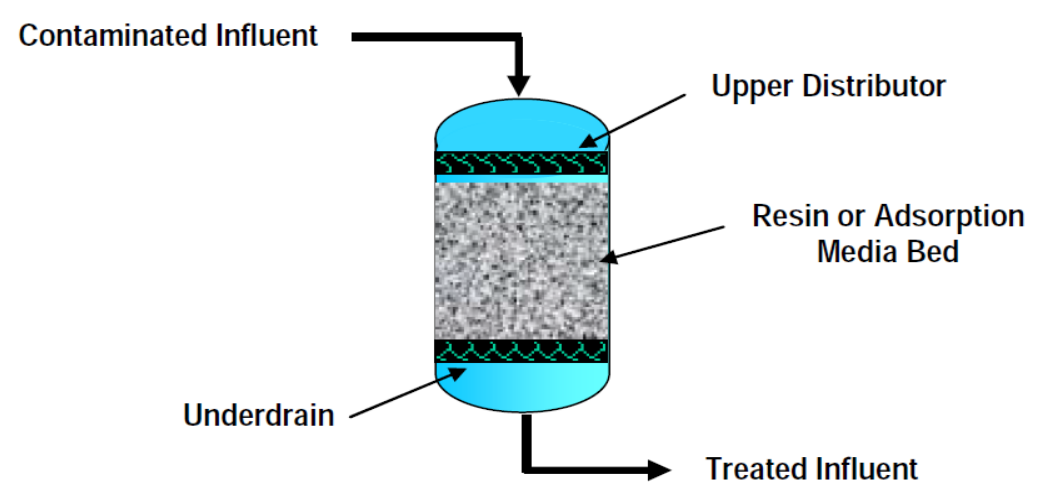

Figure 7-3: A Sketch of an Ion Exchange System

Competition for ion exchange or adsorption sites can greatly impact a given system's efficiency in removing contaminants. Generally, ions with higher valence, greater atomic weights and smaller radii are preferred by ion exchange resins and adsorption media. Competing ions lead to a reduction in capacity for the target contaminant. When the capacity of the ion exchange resin is exhausted, it is necessary to regenerate the resin using a saturated solution of the exchange ion (e.g., $\mathrm{Na}+$ or $\mathrm{Cl}$-).

Anion exchange processes will generally preferentially remove sulfate over other target contaminants. Removal of sulfate and increased chloride concentrations (as a result of the exchange) can cause an increase in the chloride-to-sulfate ratio, which has been demonstrated to cause increases in lead corrosion in some distribution systems. Strong acid anion exchange resins are generally available in two types: Type I and Type II. Type I resins contain trialkyl ammonium chloride or hydroxide, and Type II contain dialkyl 2-hydroxyethyl ammonium chloride or hydroxide. Type II resins have been demonstrated to release nitrosamines when preceded by chlorination in the treatment process or by an initial rinse following installation or regeneration. The cation exchange functional group includes sodium, which can result in an increase in finished water sodium concentrations. Disposal of spent media with high concentrations of removed contaminants may require disposal as a hazardous waste.

Approximate capital and operations and maintenance (O\&M) costs for ion exchange and adsorption are provided in Table 7-6 from Reference 2. Capital costs include the addition of ion exchange or adsorption beds, chemical storage, associated 
piping and valves, and instrumentation and controls. It should be noted that the capital is computed based on the maximum system capacity while the annual operating and maintenance cost is calculated based on the average flow rate.

Table 7-6: Approximate Costs of Ion Exchange and Adsorption [2].

\begin{tabular}{|r|l|c|c|c|c|c|}
\hline Maxium Capacity & gal/day & 10,000 & 100,000 & $1,000,000$ & $10,000,000$ & $100,000,000$ \\
\hline Average Flow & gal/day & 5,000 & 30,000 & 350,000 & $4,400,000$ & $50,000,000$ \\
\hline Capital Cost & $\$$ /gal & 2.5 & 0.8 & 0.5 & 0.5 & 0.5 \\
\hline CAPITAL COST & $\$$ & $\mathbf{2 5 , 0 0 0}$ & $\mathbf{7 5 , 0 0 0}$ & $\mathbf{5 0 0 , 0 0 0}$ & $\mathbf{5 , 0 0 0 , 0 0 0}$ & $\mathbf{5 0 , 0 0 0 , 0 0 0}$ \\
\hline O\&M Cost & $\$ /$ gal & 0.0030 & 0.0010 & 0.0008 & 0.0005 & 0.0005 \\
\hline ANNUAL O\&M COST & $\mathbf{\$ / y r}$ & $\mathbf{5 , 4 7 5}$ & $\mathbf{1 0 , 9 5 0}$ & $\mathbf{9 5 , 8 1 3}$ & $\mathbf{8 0 3 , 0 0 0}$ & $\mathbf{9 , 1 2 5 , 0 0 0}$ \\
\hline
\end{tabular}

The total condensed water from the heat exchanger system for a $500 \mathrm{MW}$ power plant was estimated to range from 8,000 to $30,000 \mathrm{gph}$ or 120,000 to $720,000 \mathrm{gpd}$, respectively. Table 7-7 shows the total capital cost and annual operating and maintenance (O\&M) cost estimates for a $500 \mathrm{MW}$ coal-fired power plant. The numbers in Table 7-7 are based on the data in Table 7-6 from Reference 2. Table 7-8 depicts the summary of the cost calculations for a water treatment system that is capable of converting the condensed water from the WRS to makeup water.

Table 7-7: Approximate Costs of an Ion Exchange Water Treatment System for Treating Condensed Water from a $500 \mathrm{MW}$ Power Plant

\begin{tabular}{|r|l|c|}
\hline Maximum Capacity & gal/day & 720,000 \\
\hline Average Flow & gal/day & 420,000 \\
\hline Capital Cost & $\$ /$ gal & 0.5304 \\
\hline CAPITAL COST & $\$$ & $\mathbf{3 8 1 , 8 8 8}$ \\
\hline O\&M Cost & $\$ /$ gal & 0.00078 \\
\hline ANNUAL O\&M COST & $\mathbf{\$} / \mathbf{y r}$ & $\mathbf{1 1 9 , 2 9 6}$ \\
\hline
\end{tabular}


Table 7-8: Unit Cost of Makeup Water from Ion

Exchange Treatment System

\begin{tabular}{|l|c|r|}
\hline Loan amount & $\$$ & $381,887.73$ \\
\hline Interest rate & $\%$ & 6.00 \\
\hline Loan term & $\mathrm{yr}$ & 20.00 \\
\hline Annual loan payments & $\$ / \mathrm{yr}$ & $\$ 32,831.55$ \\
\hline Annual O\&M cost & $\$ / \mathrm{yr}$ & $119,295.73$ \\
\hline Annual treated water & gallons & $153,300,000$ \\
\hline Total treatment syst cost & $\$ / \mathrm{yr}$ & 152,127 \\
\hline Cost of treated water & $\$ / g a l$ & 0.000992 \\
\hline
\end{tabular}

\section{Summary and Conclusions}

In this study, various water treatment options were evaluated for condensed water from flue gas water recovery heat exchangers, with the goal of using the recovered water in the cooling tower as makeup water. The quality of the makeup water used in a cooling tower does not have to be very high, however, impurities in the makeup water, such as iron, magnesium and calcium have to be below certain levels to avoid or minimize corrosion and fouling on heat transfer surfaces.

Comparisons of the chemical composition of condensed water from the heat exchanger with cooling tower, makeup water, and river water samples reveal that they are comparable except for nitrate, sulfate, and iron. In particular, iron concentrations in the condensed water are several orders of magnitude higher than those in average cooling tower water. This unusually high iron level in the condensate is most likely due to corrosion occurring on the duct walls and possibly also on some tube surfaces in the slip stream heat exchanger apparatus. The duct walls were made from carbon steel, which corrodes very rapidly in a sulfuric acid environment. The heat exchanger tubes in the region of water vapor condensation were stainless steel, which also corrodes, but at a much lower rate than carbon steel. The authors believe that the iron level would be much lower than that shown in Table 7-5 if corrosion resistant materials had been used. 
Nitrate and sulfate concentrations are higher in the condensate flow when compared to the cooling tower water. In addition, the acidity of the condensed water $(\mathrm{pH} \sim 4.72)$ is higher than that of typical makeup water $(\mathrm{pH} \sim 7.55)$ used in the cooling tower. The low level of $\mathrm{pH}$ is probably due to the high concentrations of sulfate and nitrate in the condensed water.

An ion exchange system is recommended for removal of sulfate and nitrate ions. Insoluble or precipitated iron is readily removed like other suspended solids by both clarification and filtration and ion exchange materials remove iron in the water being treated. Although the heat exchanger system is located downstream of the particulate collection devices (ESP or bag house), which filter the majority of dust particles from flue gas, very small amounts of dust particles were observed in the captured water at the bottom of the heat exchangers. Therefore, a particulate filtering (suspended solid) system is recommended as the first step in the process.

Economic analysis of the ion exchange system revealed that the cost of treated water would be about $\$ 0.001 /$ gallon (see Table $7-8$ ). This analysis does not include the capital cost and O\&M cost of the water recovery system. It only considers the treatment of the condensed water from the water recovery systems prior to its use in the cooling tower as makeup water.

\section{References}

1. U.S. Environmental Protection Agency - Water Research Foundation, "http://iaspub.epa.gov/ tdb/pages/treatment/treatmentOverview.do?treatmentProcessld=263654386", Cincinnati, Ohio, 2011.

2. Technifax, "Ion Exchange Process," Nalco Chemical Company, Naperville, Illinois, 1998.

3. Drbal, L., F., Boston, P. G., Westra, K. L., and Erickson, R. B, "Power Plant Engineering," Black \& Veatch, 1996.

4. Application Note, "Yokogawa Corporation of America," http://www.yokogawa.com/us, Report No: AD-A-003, 2008. 
5. Lintner, W., "Cooling Towers: Understanding Key Components of Cooling Towers and How to Improve Water Efficiency," U.S. Department of Energy Efficiency and Renewable Energy, Federal Energy Management Program, February 2011. 


\section{CHAPTER 8}

\section{COST-BENEFIT ANALYSES}

\section{Introduction}

The analyses described in this chapter provide estimates of the costs and benefits of utilizing a heat exchanger to cool boiler flue gas to temperatures below the water vapor dewpoint. It is assumed the condensed water is treated and then used for cooling tower makeup water and the heat captured from the flue gas is used to preheat boiler feedwater.

Three cases are presented, with one involving a condensing heat exchanger $(\mathrm{CHX})$ installed downstream of a wet FGD, and the other two involving $\mathrm{CHX}$ 's with $300^{\circ} \mathrm{F}$ inlet flue gas temperatures. In all three cases, the cooling water for the condensing heat exchanger $(\mathrm{CHX})$ is cold boiler feedwater which enters the condensing heat exchanger at $87^{\circ} \mathrm{F}$ with a flow rate which is 50 percent of the flue gas flow rate.

Case 1: Unit with Wet FGD. This case involves a unit with a wet FGD, where the flue gas leaving the FGD is saturated with water vapor at a temperature of $135^{\circ} \mathrm{F}$ and a water vapor concentration of 17.2 volume percent. The condensing heat exchanger is located downstream of the FGD, and it has sufficient heat transfer surface area to increase the temperature of the cooling water from $87^{\circ} \mathrm{F}$ to $134^{\circ} \mathrm{F}$ and reduce the flue gas temperature to $128^{\circ} \mathrm{F}$. After leaving the $\mathrm{CHX}$, the cooling water enters the first low pressure feedwater heater (FWH1) where extraction steam from the LP turbine increases the feedwater temperature to $151.9^{\circ} \mathrm{F}$ (Figure 8-1). But the amount of LP extraction steam needed for FWH1 is less than would be needed if the feedwater had entered $\mathrm{FWH} 1$ at $87^{\circ} \mathrm{F}$ instead of at $134^{\circ} \mathrm{F}$ and thus the LP turbine generates more power than it would have in the absence of the $\mathrm{CHX}$. 


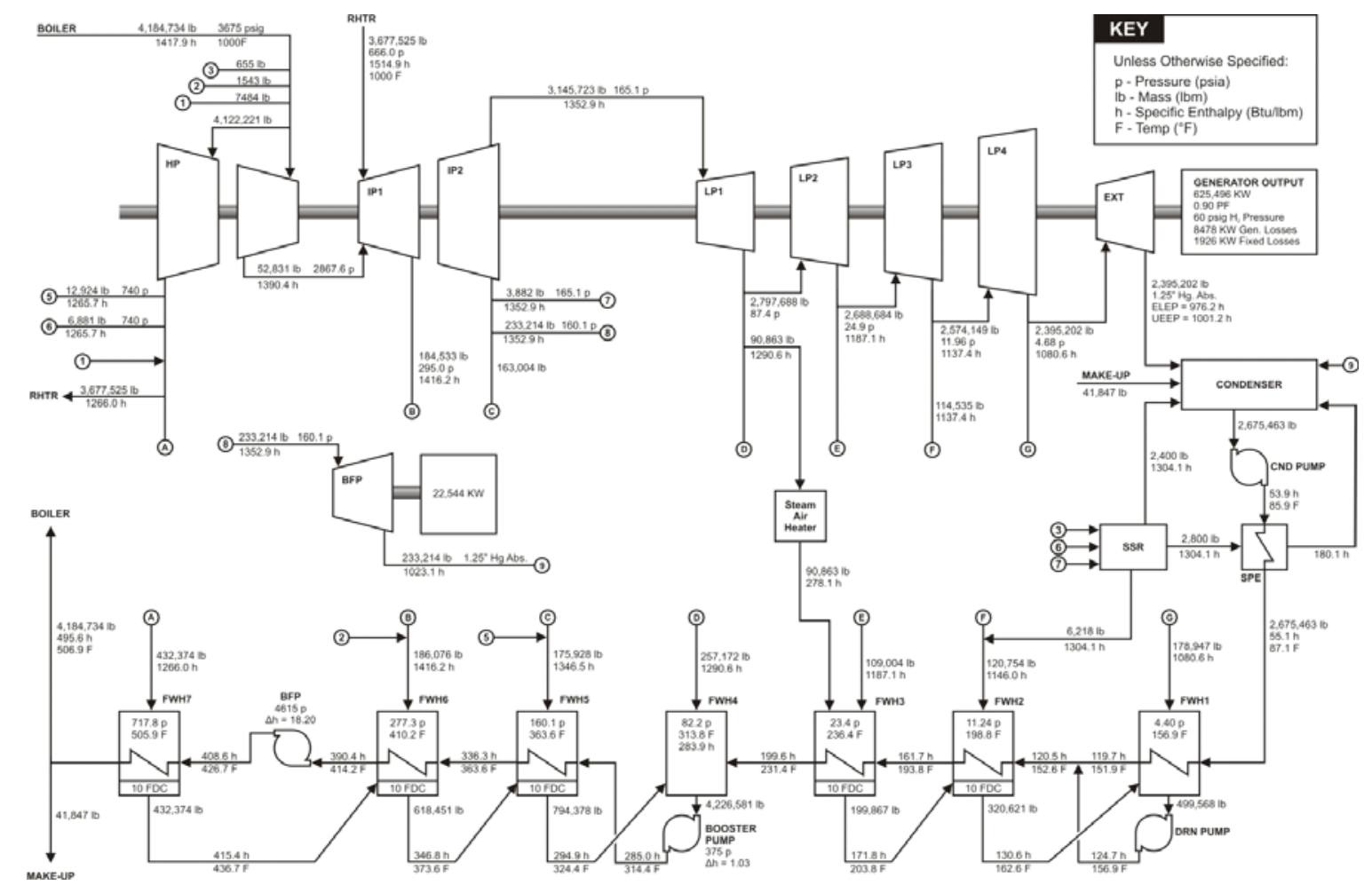

Figure 8-1: Turbine Cycle Diagram Showing Flow Rates, Temperatures and Pressures

Case 2: Unscrubbed Unit. This case involves an unscrubbed unit which fires PRB coal. The flue gas temperature at the heat exchanger inlet is $300^{\circ} \mathrm{F}$ and the flue gas inlet water vapor concentration is 12 volume percent, which is typical of a unit firing PRB coal. The condensing heat exchanger has sufficient heat transfer surface area to increase the temperature of the cooling water from $87^{\circ} \mathrm{F}$ to $211^{\circ} \mathrm{F}$ and reduce the flue gas temperature to $121^{\circ} \mathrm{F}$. In Case 2 , the normal steam turbine extractions flowing to $\mathrm{FWH} 1$ and $\mathrm{FWH} 2$ are set to zero. After leaving the $\mathrm{CHX}$, the cooling water enters the third low pressure feedwater heater (FWH3) where extraction steam from the LP turbine increases the feedwater temperature to $231.4^{\circ} \mathrm{F}$ (Figure 8-2). The amount of LP extraction steam needed for FWH3 is less than would be needed in the case without heat being available from the flue gas. That combined with zero steam turbine extraction flows to FWH1 and FWH2, results in more power produced by the LP turbine than it would have in the absence of the $\mathrm{CHX}$. 


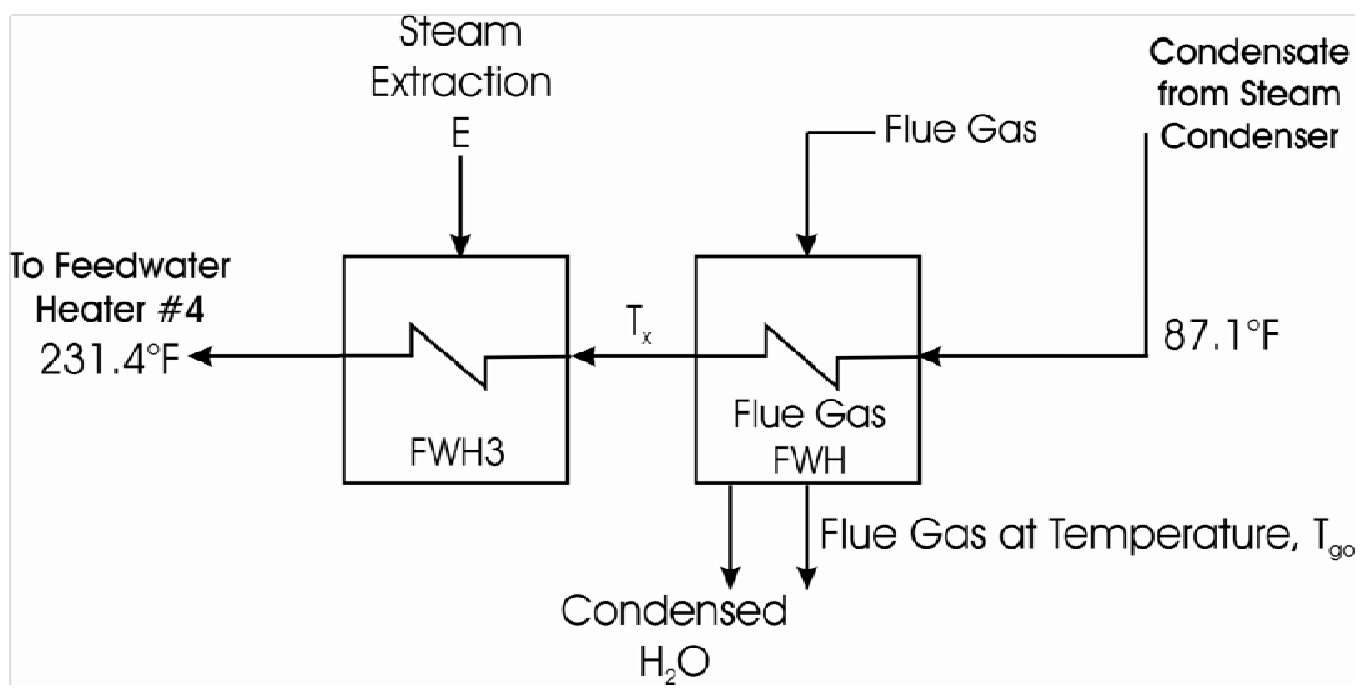

Figure 8-2: Diagram of Preheated Boiler Feedwater Entering Feedwater Heater 3

Case 3: Unscrubbed Unit. In this case, the flue gas temperature at the heat exchanger inlet is $300^{\circ} \mathrm{F}$ and the flue gas inlet water vapor volume is 12 percent. This heat exchanger has much less surface area than the one in Case 2, so that the flue gas is cooled only to $214^{\circ} \mathrm{F}$ and the cooling water temperature is increased only to $146^{\circ} \mathrm{F}$. In Case 3 , after leaving the $\mathrm{CHX}$, the cooling water enters the first low pressure feedwater heater (FWH1) where extraction steam from the LP turbine increases the feedwater temperature to $151.9^{\circ} \mathrm{F}$ But the amount of LP extraction steam needed for FWH1 is less than would be needed if the feedwater had entered $\mathrm{FWH} 1$ at $87^{\circ} \mathrm{F}$ instead of at $146^{\circ} \mathrm{F}$ and thus the LP turbine generates more power than it would have in the absence of the $\mathrm{CHX}$.

Estimates of heat exchanger capital costs were made and these were converted into annual fixed charges for the three cases. Both the cooling water and flue gas experience pressure drops as they flow through the $\mathrm{CHX}$ and the additional power needed for the ID fan and feedwater pump are included in the analyses as operating costs.

The water condensed from the flue gas is acidic and should be treated before being added to the cooling tower. Ion exchange treatment is recommended for this 
application (See Chapter 7) and the annual fixed charge and annual O\&M costs for an ion exchange system are also included.

The benefits include increased turbine power and credit for reduced external water consumption. In addition, there are reduced emissions of mercury and sulfuric, hydrochloric and nitric acids, although, for these analyses, no dollar amounts have been placed on the value of avoided stack emissions.

Values used for key parameters include 20 year equipment life, 5 percent annual interest rate, electrical power at $\$ 60 / \mathrm{MWhr}$, and cooling water at $\$ 1.50 / 1000$ gallons. The flue gas flow rate entering the $\mathrm{CHX}$ is approximately $6 \times 10^{6} \mathrm{lbm} / \mathrm{hr}$ and the cooling water flow rate is approximately $3 \times 10^{6} \mathrm{lbm} / \mathrm{hr}$. Actual flow rates for the three cases are given in Table 8-1.

\section{Analyses of Costs and Benefits}

Table 8-1 provides a summary of inlet and exit temperatures, inlet flue gas moisture concentrations, condensation and heat transfer rate data, heat exchanger surface areas, predicted improvements in net unit power increase, and cost information for the three heat exchangers. Case 1 , which represents the largest condensation rate of the three cases, has the least expensive of the heat exchangers (\$4.14 Million) and the smallest increase in net power (2.68 MW). While the heat exchanger in Case 2 has sufficient heat transfer surface area to cool the flue gas from 300 to $121^{\circ} \mathrm{F}$ and heat the cooling water to $211^{\circ} \mathrm{F}$, it has a prohibitively high installed cost ( $\$ 101.9$ million). However, because of relatively high cooling water exit temperature, this case would provide the largest increase in net power $(11.3 \mathrm{MW})$ and decrease in net unit heat rate (1.87 percent). Case 3 , which is also for a $300^{\circ} \mathrm{F}$ inlet flue gas temperature, has a much

smaller heat exchanger than Case 2 and a correspondingly smaller capital cost. As a consequence, this case results in smaller predicted power increase (3.75 MW) and heat rate decrease (0.63 percent). 
Table 8-1: Heat Exchanger Process Conditions, Heat and Mass Transfer Rates, Costs and Unit Performance Impacts

\begin{tabular}{|l|c|c|c|}
\hline PARAMETER & CASE 1 & CASE 2 & CASE 3 \\
\hline Tfg,in (F) & 135 & 300 & 300 \\
\hline Tfg,out (F) & 128 & 121 & 214 \\
\hline Tcw,in (F) & 87 & 87 & 87 \\
\hline Tcw,out (F) & 134 & 211 & 146 \\
\hline Inlet $\mathbf{H}_{\mathbf{2}}$ O Concentration (\%) & 17.2 & 12 & 12 \\
\hline Cooling Water Flow Rate (Million Ibm/hr) & 3.34 & 3 & 3 \\
\hline Flue Gas Flow Rate (Million Ibm/hr) & 6.68 & 6 & 6 \\
\hline Condensation Rate (Ibm/hr) & 141,435 & 74,414 & 31,172 \\
\hline Condensation Efficiency (\%) & 19.4 & 16.87 & 7.07 \\
\hline Heat Transfer Rate (million Btu/hr) & 158 & 371 & 175 \\
\hline Surface Area (ft ${ }^{2}$ ) & 100,625 & 596,241 & 78,200 \\
\hline Installed Cost (\$ million) & 4.14 & 101.9 & 10.59 \\
\hline Annual Operating Cost (\$ million/yr) & 0.251 & 1.06 & 0.15 \\
\hline Power Increase (MW) & 2.68 & 11.3 & 3.75 \\
\hline Decrease in Net Unit Heat Rate (\%) & -0.45 & -1.87 & -0.63 \\
\hline
\end{tabular}

Tables 8-2 to 8-4 summarize the cost-benefit calculations for the three cases. These show that the Case 1 system (Post FGD condensing heat exchanger) has estimated annual costs of $\$ 793,146$ and estimated annual benefits of $\$ 1,304,505$. Estimated annual condensate water treatment costs are approximately 25 percent of the heat exchanger capital and operating costs. The benefits are dominated by revenue from increased power sales.

The Case 2 system has estimated annual costs of $\$ 10.76$ million and annual benefits of $\$ 4.84$ million. A heat exchanger of this size, fabricated largely from Alloy 22 , would not be cost-effective due to high material cost. In contrast, the Case 3 system has estimated annual costs of $\$ 1.19$ million and estimated annual benefits of $\$ 1.614$ million. This suggests that use of condensing heat exchangers to cool flue gas to an intermediate temperature may be a cost effective strategy. While the annual benefits are less for Case 3 than for Case 2, the installed cost for the Case 3 heat exchanger is only 10 percent of that of Case 2 . 
Table 8-2: Cost-Benefit Summary: Case 1

Case 1: $135^{\circ} \mathrm{F}$ Inlet, Exit Cooling Water Temp $=134^{\circ} \mathrm{F}$

\begin{tabular}{|c|c|c|c|c|}
\hline Costs & $\begin{array}{l}\text { Capital } \\
\text { Cost (\$) }\end{array}$ & $\begin{array}{c}\text { Annual } \\
\text { Fixed Cost (\$) } \\
\end{array}$ & $\begin{array}{c}\text { Annual } \\
\text { Operating Cost(\$) } \\
\end{array}$ & $\begin{array}{c}\text { Total } \\
\text { Annual Cost (\$) }\end{array}$ \\
\hline CHX Installed Capital Cost & $4,139,425$ & 389,911 & & 389,911 \\
\hline CHX Gas and Water DP: Fan \& Pump Power & & & 251,108 & 251,108 \\
\hline Ion Exchange System Capital Cost & 381,888 & 32,831 & & 32,831 \\
\hline Ion Exchange System O\&M Cost & & & 119,296 & 119,296 \\
\hline Subtotal & & & & 793,146 \\
\hline Benefits & Amount & Unit Value & Total & Annual Benefit (\$) \\
\hline Increased Power Generation & $2.682 \mathrm{MW}$ & $\$ 60 / \mathrm{MWh}$ & $18,974 \mathrm{MWh} / \mathrm{yr}$ & $1,126,440$ \\
\hline Water Savings & $141,435 \# \mathrm{~m} / \mathrm{hr}$ & $\$ 1.50 / 1000$ gallons & $7000 \mathrm{hr} / \mathrm{yr}$ & 178,065 \\
\hline Subtotal & & & & $1,304,505$ \\
\hline Notes: & & & & \\
\hline$\$ 60 / \mathrm{MWhr}$ & & & & \\
\hline 20 year life & & & & \\
\hline $5 \%$ annual interest rate & & & & \\
\hline$\$ 1.50 / 1000$ gallons & & & & \\
\hline 600 MW Unit & & & & \\
\hline
\end{tabular}

Table 8-3: Cost-Benefit Summary: Case 2

Case 2: $300^{\circ} \mathrm{F}$ Inlet, Exit Cooling Water Temp $=210^{\circ} \mathrm{F}$

\begin{tabular}{|c|c|c|c|c|}
\hline Costs & $\begin{array}{l}\text { Capital } \\
\text { Cost (\$) }\end{array}$ & $\begin{array}{c}\text { Annual } \\
\text { Fixed Cost (\$) }\end{array}$ & $\begin{array}{c}\text { Annual } \\
\text { Operating Cost(\$) }\end{array}$ & $\begin{array}{c}\text { Total } \\
\text { Annual Cost (\$) }\end{array}$ \\
\hline CHX Installed Capital Cost & $101,878,000$ & $9,596,000$ & & $9,596,000$ \\
\hline CHX Gas and Water DP:Fan \& Pump Power & & & $1,058,400$ & $1,058,400$ \\
\hline Ion Exchange System Capital Cost & 381888 & 32831 & & 32831 \\
\hline Ion Exchange System O\&M Cost & & & 74,560 & 74,560 \\
\hline Subtotal & & & & $10,761,791$ \\
\hline Benefits & Amount & Unit Value & Total & Annual Benefit (\$) \\
\hline Increased Power Generation & $11.3 \mathrm{MW}$ & $\$ 60 / \mathrm{MWh}$ & $79,100 \mathrm{MWh} / \mathrm{yr}$ & $4,746,000$ \\
\hline Water Savings & $75,000 \# \mathrm{~m} / \mathrm{hr}$ & $\$ 1.50 / 1000$ gallons & $7000 \mathrm{hr} / \mathrm{yr}$ & 94,424 \\
\hline Subtotal & & & & $4,840,424$ \\
\hline
\end{tabular}

Notes:

$\$ 60 / \mathrm{MWhr}$

20 year life

$5 \%$ annual interest rate

$\$ 1.50 / 1000$ gallons

600 MW Unit 
Table 8-4: Cost-Benefit Summary: Case 3

Case 3: $300^{\circ} \mathrm{F}$ Inlet, Exit Cooling Water Temp $=146^{\circ} \mathrm{F}$

\begin{tabular}{|c|c|c|c|c|}
\hline Costs & $\begin{array}{l}\text { Capital } \\
\text { Cost (\$) } \\
\end{array}$ & $\begin{array}{c}\text { Annual } \\
\text { Fixed Cost (\$) }\end{array}$ & $\begin{array}{c}\text { Annual } \\
\text { Operating Cost(\$) } \\
\end{array}$ & $\begin{array}{c}\text { Total } \\
\text { Annual Cost (\$) } \\
\end{array}$ \\
\hline CHX Installed Capital Cost & $10,590,000$ & 998,000 & & 998,000 \\
\hline CHX Gas and Water DP:Fan \& Pump Power & & & 146,400 & 146,400 \\
\hline Ion Exchange System Capital Cost & 190,000 & 16,334 & & 16,334 \\
\hline Ion Exchange System O\&M Cost & & & 29,824 & 29,824 \\
\hline Subtotal & & & & $1,190,558$ \\
\hline Benefits & Amount & Unit Value & Total & Annual Benefit (\$) \\
\hline Increased Power Generation & $3.75 \mathrm{MW}$ & $\$ 60 / \mathrm{MWh}$ & $26,250 \mathrm{MWh} / \mathrm{yr}$ & $1,575,000$ \\
\hline Water Savings & $31,200 \# \mathrm{~m} / \mathrm{hr}$ & $\$ 1.50 / 1000$ gallons & $7000 \mathrm{hr} / \mathrm{yr}$ & 39,280 \\
\hline Subtotal & & & & $1,614,280$ \\
\hline
\end{tabular}

Notes:

$\$ 60 / \mathrm{MWhr}$

20 year life

$5 \%$ annual interest rate

$\$ 1.50 / 1000$ gallons

$600 \mathrm{MW}$ Unit

\section{Conclusions}

Results presented in this Chapter suggest that condensing heat exchangers installed downstream of wet FGD's would be cost effective. The benefits would include capture of water from flue gas for use within the power plant and increase in net unit power output. Estimated annual benefits are $\$ 1.304$ million vs. costs of $\$ 0.793$ million.

Condensing heat exchangers for use upstream of wet FGD's or at units which do not have wet scrubbers may be cost effective if they are designed to cool flue gas to intermediate temperatures. Such a design strategy would restrict heat exchanger annual costs to levels below the financial benefit derived from increased power generation obtained from using flue gas heat to preheat boiler feedwater.

Finally, it should be noted that no credit was taken in these analyses for financial benefits from decreased emissions of $\mathrm{NO}_{x}, \mathrm{SO}_{x}$ and $\mathrm{Hg}$. Quantification of these factors would provide increased financial justification for using condensing heat exchangers. 


\section{CHAPTER 9}

\section{SUMMARY}

This report, which is the final technical report for DOE project DE-NT0005648, describes the continued development of condensing heat exchanger technology for coal-fired boilers. The report describes results of slip stream tests performed at coalfired power plants, theoretical predictions for acid concentrations in liquid deposits at surface temperatures above the water vapor dewpoint temperature, laboratory corrosion data on candidate tube materials, data on the effectiveness of acid traps in reducing sulfuric acid concentrations in heat exchanger tube bundles, designs of full scale heat exchangers and installed capital costs, condensed water treatment needs and costs, and results of cost-benefit studies of condensing heat exchangers.

Power Plant Slip Stream Tests. An expanded data base on water and acid condensation characteristics of boiler flue gas with water-cooled condensing heat exchangers was generated from slip stream tests at coal-fired power plants. The units included one which fires high sulfur bituminous coal and has a wet FGD scrubber and two which are unscrubbed and fire high-moisture low rank coals (Chapter 2). In the case of the two unscrubbed units, the flue gas slip streams were obtained from flue gas ducts downstream of the ESP's, while the flue gas slip stream from the third boiler was taken just downstream of the wet FGD. The results show strong dependence of total heat transfer and water vapor capture efficiency on flow rate ratio of cooling water to flue gas and inlet cooling water temperature. If cold boiler feedwater is used as the cooling fluid, the flow rate ratio of cooling water to flue gas will be approximately 0.5 and water vapor capture efficiencies will be limited to approximately 20 percent. For applications in which flow rates of cooling water greater than the flow rate of cold boiler feedwater are available, water vapor capture efficiencies significantly greater than 20 percent will be possible.

As boiler flue gas is reduced in temperature below the sulfuric acid dew point, the acid first condenses as a highly concentrated solution of sulfuric acid and water. Based 
on thermodynamic liquid-vapor phase equilibrium calculations for sulfuric acid-water mixtures, concentrations of sulfuric acid in the condensate will depend on vapor phase $\mathrm{H}_{2} \mathrm{SO}_{4}$ and $\mathrm{H}_{2} \mathrm{O}$ concentrations and will range from 75 to 85 weight percent (Chapter 3).

Flue gas from coal-fired boilers contains relatively high water vapor concentrations, with water vapor dewpoint temperatures from 100 to $135^{\circ} \mathrm{F}$, depending on coal moisture content. For those applications in which the flue gas temperature is reduced to temperatures below the water vapor dewpoint, the liquid mixture of water and sulfuric acid which forms is approximately two orders of magnitude more dilute in sulfuric acid than the highly concentrated acid solutions which form at temperatures above the water vapor dewpoint temperature, but below the sulfuric acid dew point temperature.

Both $\mathrm{HCl}$ and $\mathrm{HNO}_{3}$ condense at temperatures less than $140^{\circ} \mathrm{F}$. Samples of water which had condensed on the heat exchangers were analyzed to determine concentrations of sulfuric, hydrochloric and nitric acids. The measured concentrations of $\mathrm{HCl}$ and $\mathrm{HNO}_{3}$ in the condensate were significantly lower than those of $\mathrm{H}_{2} \mathrm{SO}_{4}$, with the range of values of each summarized in Table 9-1 (Chapter 2).

Table 9-1: Measured Acid Concentrations (mg/L) in Condensate which Formed at Temperatures Below the Water Vapor Dew Point Temperature

\begin{tabular}{|l|c|c|c|}
\hline & Unit A & Unit B & Unit C \\
\hline $\mathrm{H}_{2} \mathrm{SO}_{4}$ & 100 to 350 & 200 to 1800 & 50 to 1400 \\
\hline $\mathrm{HCl}$ & 10 to 100 & 5 to 55 & 0 to 15 \\
\hline $\mathrm{HNO}_{3}$ & 0.5 to 2 & 2 to 15 & 0 \\
\hline
\end{tabular}

Mercury measurements were also made during tests at two of the units, and the results showed that vapor phase mercury decreased by 60 percent between the inlet and exit of the heat exchanger system at one unit and from 30 to 80 percent at the second, with the percentage capture increasing as the flue gas exit temperature decreased (Chapter 2).

Laboratory Corrosion Tests. Laboratory corrosion tests, designed to simulate the corrosive condensate solutions encountered in field tests carried out in the project, 
were conducted to identify materials which would have adequate service life. The corrosion tests were performed in aqueous solutions containing sulfuric acid at concentration levels representative of both dilute and high acid concentration conditions. The dilute aqueous solutions also contained hydrochloric and nitric acids at concentration levels observed during the slip stream field tests.

The corrosion tests showed that all materials tested except carbon steel exhibited acceptable corrosion rates in dilute acid solutions. Of the remaining alloys, 304 stainless steel was found to be the preferred choice due to relatively low cost, ease of fabrication, and negligible corrosion rates over the entire range of test conditions.

Alloys 22 and 690 along with two Teflon materials (FEP and PTFE) showed the best performance at high acid concentration conditions. The Teflons showed no significant signs of degradation over the entire range of acid composition. Alloys 22 and 690 exhibited increased corrosion rates with increasing acid concentration and temperature, but should provide acceptable performance up to 74 percent $\mathrm{H}_{2} \mathrm{SO}_{4}$ and $115^{\circ} \mathrm{C}$. Alloy 22 is the preferred alloy for the high acid concentration due to its low corrosion rate, high yield strength and thermal conductivity and ability to be readily fabricated. Corrosion resistance of welds will also be important for condensing heat exchangers, and the test data showed the corrosion rates of welded 22 and 625 alloy test specimens were not significantly different than corrosion rates of the wrought alloys.

Teflon coatings MP501 and Ruby Red were found to be poor candidates for this application due to evidence of permeation, leaching of the coating, and complete coating failure under the most aggressive test conditions.

Effectiveness of Acid Traps. One of the project tasks involved tests to assess the potential of reducing the flue gas sulfuric acid concentration entering the heat exchangers through use of additional surface area in the inlet region to capture a portion of the inlet $\mathrm{H}_{2} \mathrm{SO}_{4}$. The concept involves use of a section of inlet duct filled with closely spaced vertical flat plates aligned parallel to the flow direction (referred to as "acid traps" in this report). Tests were carried out with acid traps located upstream of 
the first heat exchanger ( $\mathrm{HX} 1)$, between $\mathrm{HX} 1$ and $\mathrm{HX} 2$, and both upstream and downstream of $\mathrm{HX1}$. The test results show that acid traps can be effective at reducing the quantities of sulfuric acid flowing into the heat exchangers. At temperatures above the water vapor dewpoint, the acid traps reduced the vapor phase acid concentrations entering the heat exchangers just downstream of the traps by 10.2 to 13.7 percent. At temperatures at or below the water vapor dew point, the presence of an acid trap reduced the sulfuric acid flux on the heat exchanger positioned just downstream of the trap by 33 to 42 percent.

Design of Full-Scale Heat Exchangers. Heat exchanger design software developed by the project team was used to estimate how much flue gas moisture it would be possible to recover from boiler flue gas, the size and cost of the heat exchangers, and flue gas and cooling water pressure drops. The laboratory corrosion test data showed that at locations in the flue gas upstream of the water vapor dewpoint, the choice of tube material is between Teflon and Alloy 22. Heat exchanger design calculations show that the relatively low thermal conductivity of Teflon would prevent water vapor condensation with a Teflon heat exchanger. In addition, while Teflon is less expensive than Alloy 22 per foot of tubing, it has extremely low values of thermal conductivity and tensile strength compared to Alloy 22 . In order to transfer the same amount of heat, the Teflon heat exchanger would need to have approximately three times the surface area of an Alloy 22 heat exchanger, and this would also result in larger pump and fan power requirements than would be needed for the Alloy 22 heat exchanger. As a consequence, the total annual costs for a Teflon heat exchanger would be greater than for a heat exchanger fabricated from Alloy 22 .

Because of its corrosion resistance in aqueous solutions with low acid concentrations, relatively low cost and high tensile strength and thermal conductivity, 304 SS is the preferred choice for heat exchanger tubing at temperatures below the water vapor dew point.

There will be separate applications for condensing heat exchangers, depending on coal type. A boiler firing a Powder River Basin coal may not need a wet $\mathrm{SO}_{2}$ 
scrubber, and in this case, the flue gas temperature at the inlet of the condensing heat exchanger will be in the $300^{\circ} \mathrm{F}$ range with inlet water vapor concentrations of approximately 12 volume percent. For those applications in which a wet FGD is needed for $\mathrm{SO}_{2}$ control (bituminous coals and some lignites typically require wet FGD's), the flue gas entering the condensing heat exchanger will be saturated with water vapor and have a temperature ranging from 125 to $135^{\circ} \mathrm{F}$, with the temperature depending on coal moisture content.

If the heat exchangers are water cooled, the available cooling water flow rate and temperature will govern whether the heat exchangers are better suited for improving unit heat rate or recovering water vapor from flue gas for use as cooling tower makeup water. For applications in which water conservation is the principal concern, a likely source of cooling water will be cold boiler feedwater leaving the steam condenser. The flow rate of cold boiler feedwater is typically about one half of the flue gas flow rate of the unit and depending on time of year, the feedwater temperature typically ranges from 85 to $110^{\circ} \mathrm{F}$. Recovery of water vapor from flue gas can be enhanced through a combination of water and air-cooled heat exchangers.

For applications in which heat rate improvement is the principal concern, in order to maximize the total rate of heat transfer rate, the flue gas heat exchangers will need to be cooled with cooling water-to-flue gas flow ratios which are larger than 0.5 and cooling water inlet temperatures which are lower than typical cold boiler feedwater temperatures.

Treatment of Condensed Water. Various water treatment options were evaluated for condensed water from flue gas water recovery heat exchangers, with the goal of using the recovered water in the cooling tower as makeup water. Comparisons of the chemical composition of condensed water with cooling tower water, makeup water, and river water samples reveal that they are comparable except for nitrate, sulfate, iron and $\mathrm{pH}$ level. An ion exchange system is recommended for this application, and cost analysis of the ion exchange system revealed that the cost of water treatment would be approximately $\$ 0.001 /$ gallon. 
Cost-Benefit Analyses. Chapter 8 provides estimates of the costs and benefits of utilizing heat exchangers to cool boiler flue gas to temperatures below the water vapor dewpoint for three cases. The analyses assume the condensed water is treated and then used for cooling tower makeup water and the heat captured from the flue gas is used to preheat boiler feedwater.

Case 1 involves a condensing heat exchanger ( $\mathrm{CHX}$ ) installed downstream of a wet FGD and Case 2 involves an unscrubbed PRB-fired unit with the $\mathrm{CHX}$ having $300^{\circ} \mathrm{F}$ inlet and $120^{\circ} \mathrm{F}$ exit flue gas temperatures. Case 3 also involves an unscrubbed PRB-fired unit, but with the $\mathrm{CHX}$ having $300^{\circ} \mathrm{F}$ inlet and $214^{\circ} \mathrm{F}$ exit flue gas temperatures. In all three cases, the cooling water for the condensing heat exchanger $(\mathrm{CHX})$ is cold boiler feedwater which enters the condensing heat exchanger at $87^{\circ} \mathrm{F}$ with a flow rate which is 50 percent of the flue gas flow rate.

Estimates of heat exchanger capital costs were made and these were converted into annual fixed charges for the three cases. Both the cooling water and flue gas experience pressure drops as they flow through the $\mathrm{CHX}$ and the additional power needed for the ID fan and feedwater pump are included in the analyses as operating costs. The annual fixed charges and annual O\&M costs for ion exchange systems are also included in the cost-benefit analyses.

The benefits include increased turbine power, credit for reduced external water consumption and credit for reduced emissions of mercury and sulfuric, hydrochloric and nitric acids. For these analyses, no dollar amounts were placed on the value of avoided stack emissions.

The results suggest that condensing heat exchangers installed downstream of wet FGD's would be cost effective (Table 9-2). The benefits would include capture of water from flue gas for use within the power plant and increase in net unit power output. Estimated annual benefits are $\$ 1.304$ million vs. costs of $\$ 0.793$ million. 
The results also show that condensing heat exchangers for use upstream of wet FGD's or at units which do not have wet scrubbers may be cost effective if they are designed to cool flue gas to intermediate temperatures (Tables 9-3 and 9-4). Such a design strategy would restrict heat exchanger annual costs to levels below the financial benefit derived from increased power generation obtained from using flue gas heat to preheat boiler feedwater.

Table 9-2: Cost-Benefit Analysis for Heat Exchanger Located Downstream of Wet FGD

Case 1: $135^{\circ} \mathrm{F}$ Inlet, Exit Cooling Water Temp $=134^{\circ} \mathrm{F}$

\begin{tabular}{|c|c|c|c|c|}
\hline Costs & $\begin{array}{l}\text { Capital } \\
\text { Cost (\$) } \\
\end{array}$ & $\begin{array}{c}\text { Annual } \\
\text { Fixed Cost (\$) } \\
\end{array}$ & $\begin{array}{c}\text { Annual } \\
\text { Operating Cost(\$) } \\
\end{array}$ & $\begin{array}{c}\text { Total } \\
\text { Annual Cost (\$) } \\
\end{array}$ \\
\hline CHX Installed Capital Cost & $4,139,425$ & 389,911 & & 389,911 \\
\hline CHX Gas and Water DP: Fan \& Pump Power & & & 251,108 & 251,108 \\
\hline Ion Exchange System Capital Cost & 381,888 & 32,831 & & 32,831 \\
\hline Ion Exchange System O\&M Cost & & & 119,296 & 119,296 \\
\hline Subtotal & & & & 793,146 \\
\hline Benefits & Amount & Unit Value & Total & Annual Benefit (\$) \\
\hline Increased Power Generation & $2.682 \mathrm{MW}$ & $\$ 60 / \mathrm{MWh}$ & $18,974 \mathrm{MWh} / \mathrm{yr}$ & $1,126,440$ \\
\hline Water Savings & $141,435 \# \mathrm{~m} / \mathrm{hr}$ & $\$ 1.50 / 1000$ gallons & $7000 \mathrm{hr} / \mathrm{yr}$ & 178,065 \\
\hline Subtotal & & & & $1,304,505$ \\
\hline
\end{tabular}

Notes:

$\$ 60 / \mathrm{MWhr}$

20 year life

$5 \%$ annual interest rate

$\$ 1.50 / 1000$ gallons

$600 \mathrm{MW}$ Unit 


\section{Table 9-3: Cost-Benefit Analysis of Heat Exchanger in Unit Without Wet FGD and with $210^{\circ} \mathrm{F}$ Cooling Water Exit Temperature}

Case 2: $300^{\circ} \mathrm{F}$ Inlet, Exit Cooling Water Temp $=210^{\circ} \mathrm{F}$

\begin{tabular}{|c|c|c|c|c|}
\hline Costs & $\begin{array}{l}\text { Capital } \\
\text { Cost (\$) }\end{array}$ & $\begin{array}{c}\text { Annual } \\
\text { Fixed Cost (\$) }\end{array}$ & $\begin{array}{c}\text { Annual } \\
\text { Operating Cost(\$) }\end{array}$ & $\begin{array}{c}\text { Total } \\
\text { Annual Cost (\$) }\end{array}$ \\
\hline CHX Installed Capital Cost & $101,878,000$ & $9,596,000$ & & $9,596,000$ \\
\hline CHX Gas and Water DP:Fan \& Pump Power & & & $1,058,400$ & $1,058,400$ \\
\hline Ion Exchange System Capital Cost & 381888 & 32831 & & 32831 \\
\hline Ion Exchange System O\&M Cost & & & 74,560 & 74,560 \\
\hline Subtotal & & & & $10,761,791$ \\
\hline Benefits & Amount & Unit Value & Total & Annual Benefit (\$) \\
\hline Increased Power Generation & $11.3 \mathrm{MW}$ & $\$ 60 / M W h$ & 79,100 MWh/yr & $4,746,000$ \\
\hline Water Savings & $75,000 \# \mathrm{~m} / \mathrm{hr}$ & $\$ 1.50 / 1000$ gallons & $7000 \mathrm{hr} / \mathrm{yr}$ & 94,424 \\
\hline Subtotal & & & & $4,840,424$ \\
\hline
\end{tabular}

\section{Notes:}

\section{$\$ 60 / \mathrm{MWhr}$}

20 year life

$5 \%$ annual interest rate

$\$ 1.50 / 1000$ gallons

600 MW Unit

\section{Table 9-4: Cost-Benefit Analysis of Heat Exchanger in Unit Without Wet FGD and with $146^{\circ} \mathrm{F}$ Cooling Water Exit Temperature}

Case 3: $300^{\circ} \mathrm{F}$ Inlet, Exit Cooling Water Temp $=146^{\circ} \mathrm{F}$

\begin{tabular}{|c|c|c|c|c|}
\hline Costs & $\begin{array}{l}\text { Capital } \\
\text { Cost (\$) }\end{array}$ & $\begin{array}{c}\text { Annual } \\
\text { Fixed Cost (\$) } \\
\end{array}$ & $\begin{array}{c}\text { Annual } \\
\text { Operating Cost(\$) }\end{array}$ & $\begin{array}{c}\text { Total } \\
\text { Annual Cost (\$) } \\
\end{array}$ \\
\hline CHX Installed Capital Cost & $10,590,000$ & 998,000 & & 998,000 \\
\hline CHX Gas and Water DP:Fan \& Pump Power & & & 146,400 & 146,400 \\
\hline Ion Exchange System Capital Cost & 190,000 & 16,334 & & 16,334 \\
\hline Ion Exchange System O\&M Cost & & & 29,824 & 29,824 \\
\hline Subtotal & & & & $1,190,558$ \\
\hline Benefits & Amount & Unit Value & Total & Annual Benefit (\$) \\
\hline Increased Power Generation & $3.75 \mathrm{MW}$ & $\$ 60 / \mathrm{MWh}$ & $26,250 \mathrm{MWh} / \mathrm{yr}$ & $1,575,000$ \\
\hline Water Savings & $31,200 \# \mathrm{~m} / \mathrm{hr}$ & $\$ 1.50 / 1000$ gallons & $7000 \mathrm{hr} / \mathrm{yr}$ & 39,280 \\
\hline Subtotal & & & & $1,614,280$ \\
\hline
\end{tabular}

\section{Notes:}

$\$ 60 / \mathrm{MWhr}$

20 year life

$5 \%$ annual interest rate

$\$ 1.50 / 1000$ gallons

600 MW Unit 


\section{APPENDIX A}

\section{ALLOY PROPERTIES AND CORROSION TEST DATA}

Table A: The Candidate Alloys and Their Compositions

\begin{tabular}{|c|c|c|c|c|c|c|c|c|c|c|c|}
\hline & C & $\mathrm{Mn}$ & $\mathrm{Si}$ & $\mathrm{Ni}$ & $\mathrm{Cr}$ & Mo & $\mathrm{Fe}$ & $\mathrm{Cu}$ & Zinc & $\mathrm{Al}$ & $\mathrm{Mg}$ \\
\hline 1018 & $0.15-0.20$ & $0.60-0.90$ & - & - & - & - & Balance & - & - & - & - \\
\hline Coreten B & 0.2 (max) & $0.75-1.25$ & $0.15-0.3$ & $0.25-0.5$ & $0.4-0.7$ & - & Balance & $0.2-0.4$ & - & - & - \\
\hline 304 & 0.08 (max) & 2.0 (max) & $1.0(\max )$ & 8.0-10.5 & $18.0-20.0$ & - & Balance & - & - & - & - \\
\hline 316 & 0.07 (max) & 2.0 (max) & 1.0 (max) & $10.0-14.0$ & $16.0-18.0$ & $2.0-3.0$ & Balance & - & - & - & - \\
\hline 3003 & - & $1.0-1.5$ & 0.6 (max) & - & - & - & 0.7 (max) & $0.05-0.20$ & 0.1 (max) & Balance & - \\
\hline 6061 & - & 0.15 (max) & $0.40-0.8$ & - & $0.04-0.35$ & - & 0.7 (max) & $0.15-0.40$ & 0.25 (max) & Balance & $\begin{array}{l}0.8- \\
1.2 \\
\end{array}$ \\
\hline 600 & 0.15 (max) & 1.00 (max) & 0.50 (max) & Balance & $14.0-17.0$ & - & $6.00-10.00$ & 0.50 (max) & - & - & - \\
\hline 601 & 0.1 & 1 & 0.5 & $58-63$ & 21-25 & - & Balance & - & - & $1.0-1.7$ & - \\
\hline Alloy 59 & 0.1 & 0.5 & 0.1 & Balance & $22-24$ & $15-16.5$ & 1.5 & - & - & 0.4 & - \\
\hline $\begin{array}{l}\text { Aluminum } \\
\text { Bronze D }\end{array}$ & - & $1(\max )$ & - & - & - & - & $1.5-3.5$ & Balance & 0.2 (max) & $6.0-8.0$ & - \\
\hline
\end{tabular}

Thickness Loss (mm) vs. Time for $60 \% \mathrm{H} 2 \mathrm{SO}, 121^{\circ} \mathrm{C}$

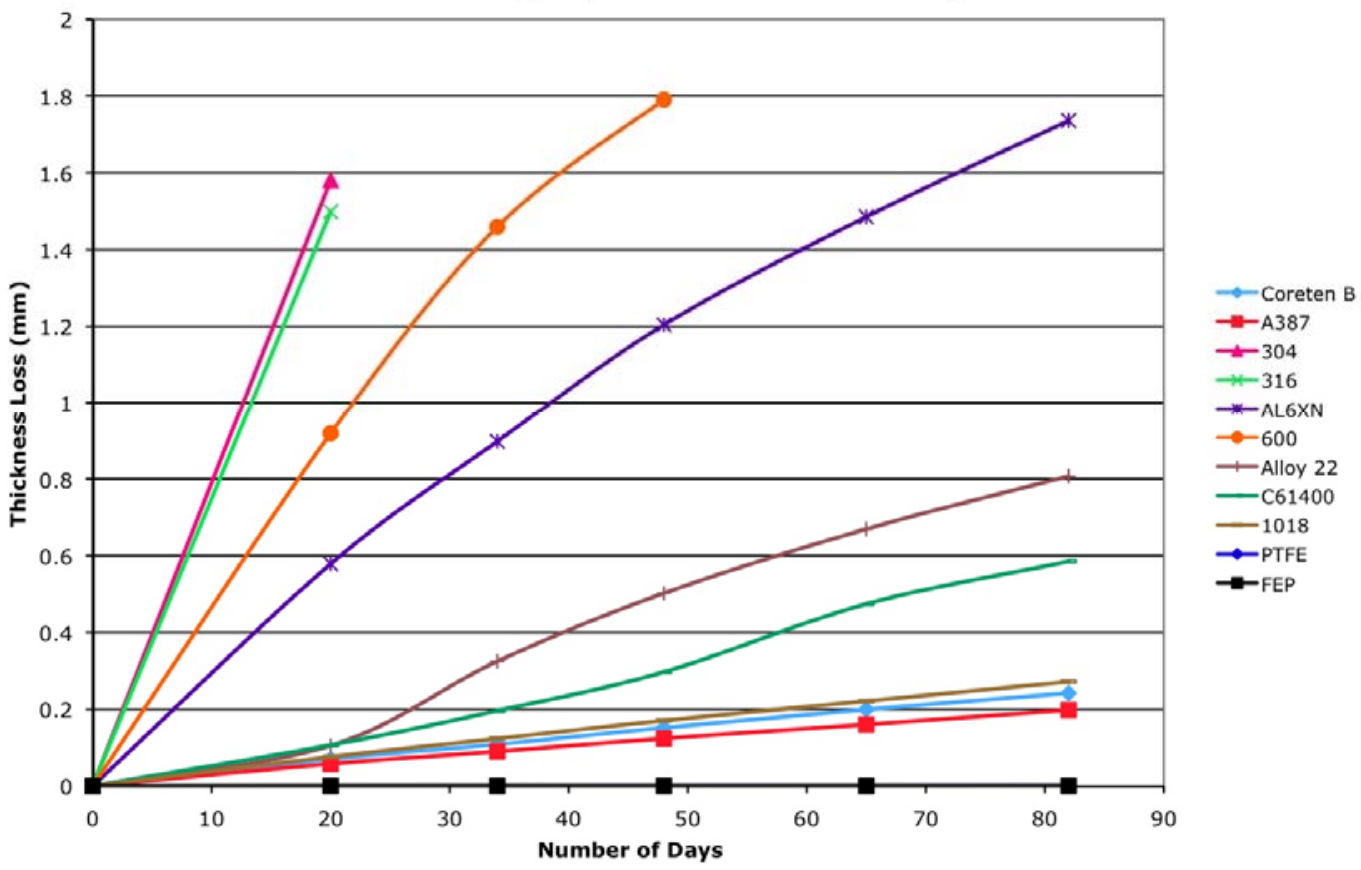

Figure A1: Plot of Thickness Loss in mm Versus Time in Days for Materials in a 60 Percent $\mathrm{H}_{2} \mathrm{SO}_{4}$ Solution at $121^{\circ} \mathrm{C}$. 
Thickness Loss vs. time for $65 \% \mathrm{H} 2 \mathrm{SO} 4,50^{\circ} \mathrm{C}$

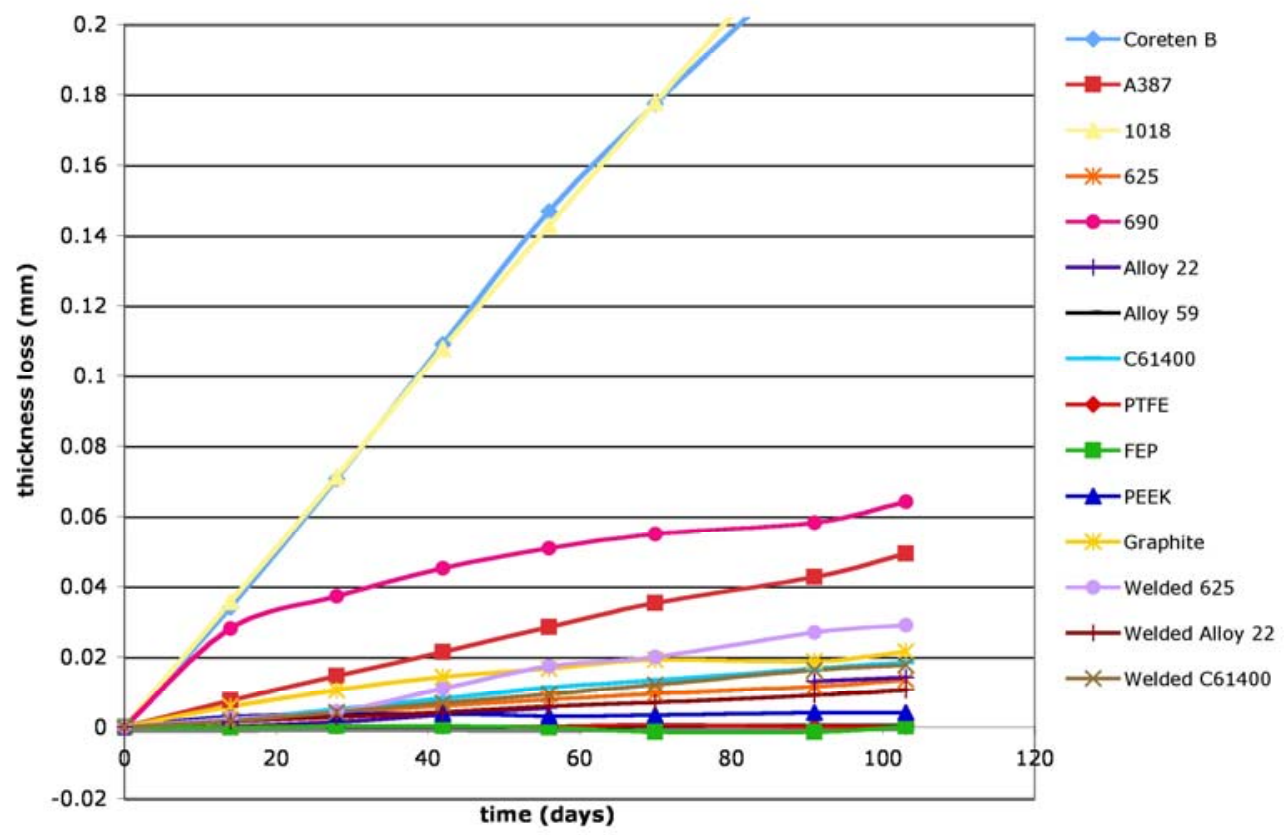

Figure A2a: Plot of Thickness Loss in mm Versus Time in Days for Materials in a 65 Percent $\mathrm{H}_{2} \mathrm{SO}_{4}$ Solution at $50^{\circ} \mathrm{C}$.

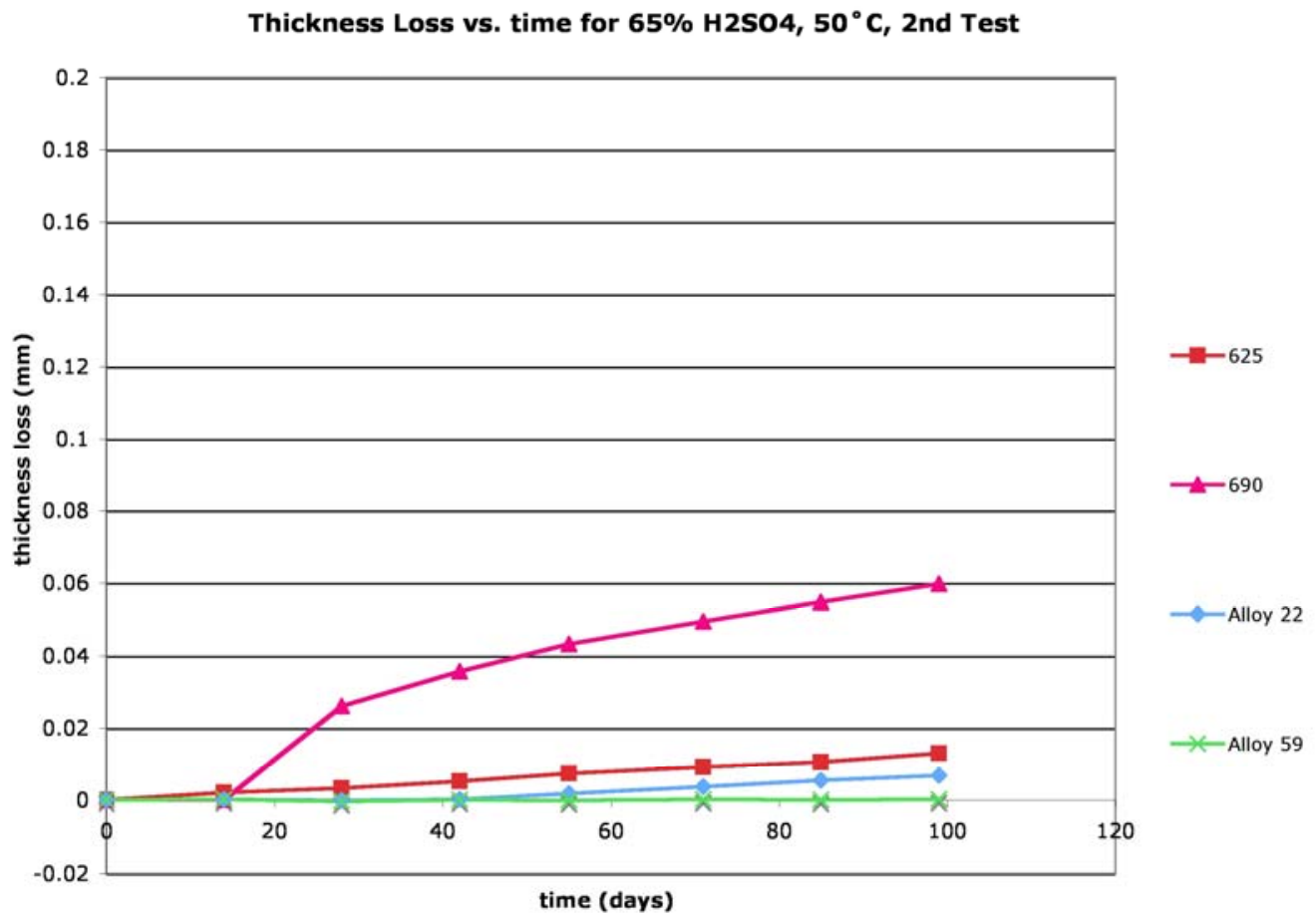

Figure A2b: Plot of Thickness Loss in $\mathrm{mm}$ Versus Time in Days for Materials in a 65 Percent $\mathrm{H}_{2} \mathrm{SO}_{4}$ Solution at $50^{\circ} \mathrm{C}$ that was Retested to Confirm the Trends. 
Thickness Loss vs. time for $67 \% \mathrm{H2SO} 4,67.5^{\circ} \mathrm{C}$

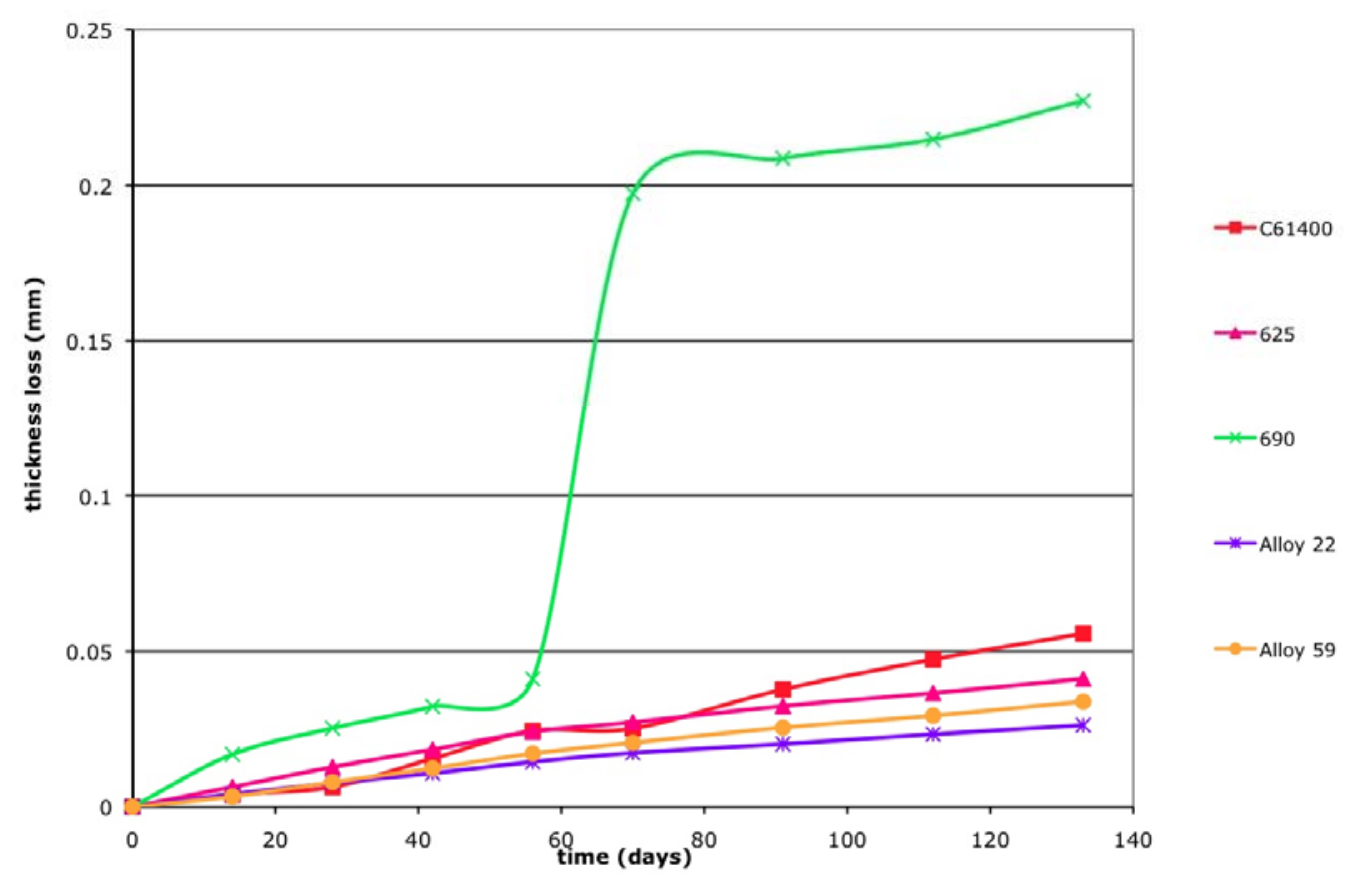

Figure A3a: Plot of Thickness Loss in mm Versus Time in Days for Materials in a 67 Percent $\mathrm{H}_{2} \mathrm{SO}_{4}$ Solution at $67.5^{\circ} \mathrm{C}$.

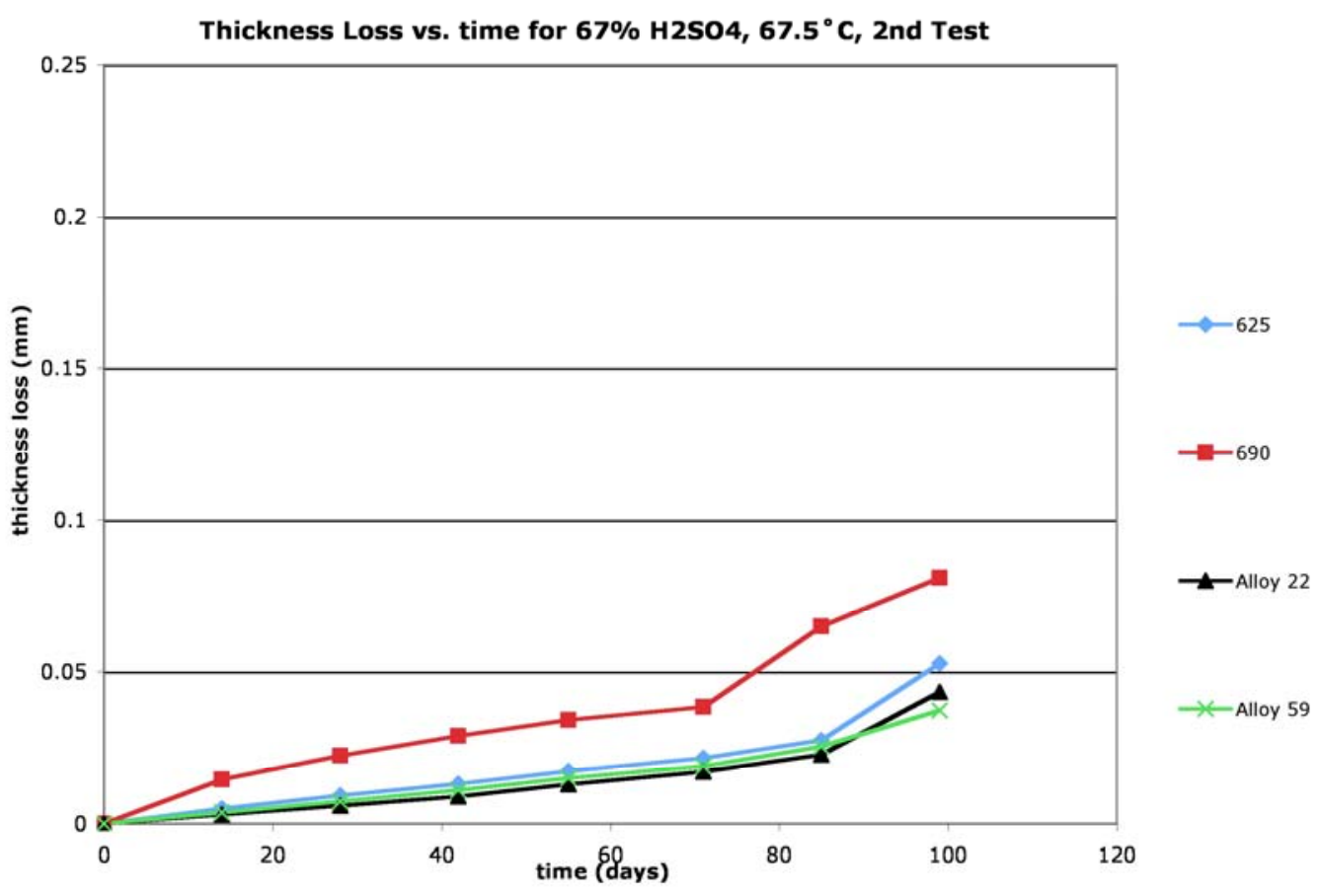

Figure A3b: Plot of Thickness Loss in mm Versus Time in Days for Materials in a 67 Percent $\mathrm{H}_{2} \mathrm{SO}_{4}$ Solution at $67.5^{\circ} \mathrm{C}$ Tested a Second Time to Confirm Trends. 


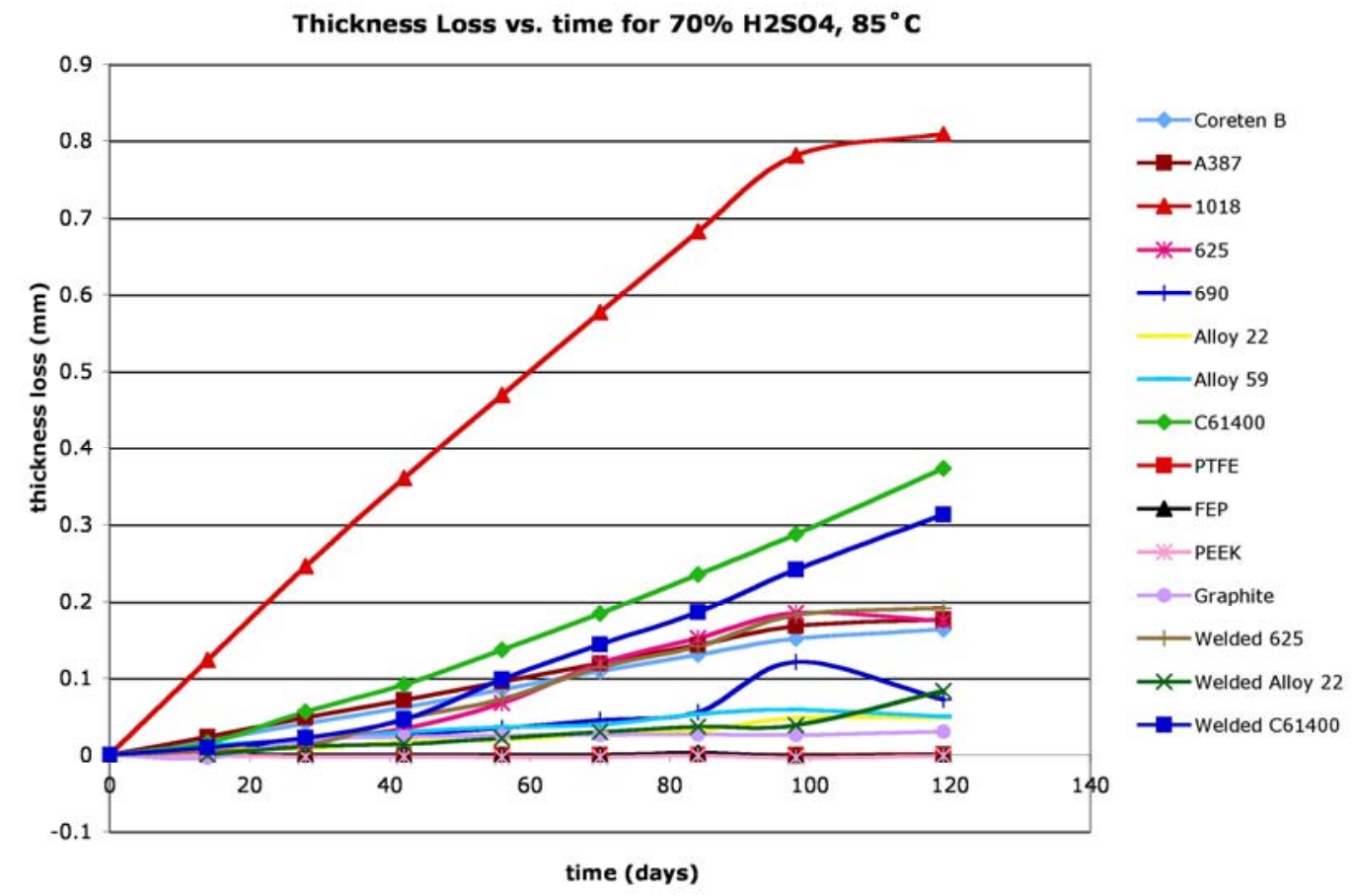

Figure A4a: Plot of Thickness Loss in mm Versus Time in Days for Materials in a 70 Percent $\mathrm{H}_{2} \mathrm{SO}_{4}$ Solution at $85^{\circ} \mathrm{C}$.

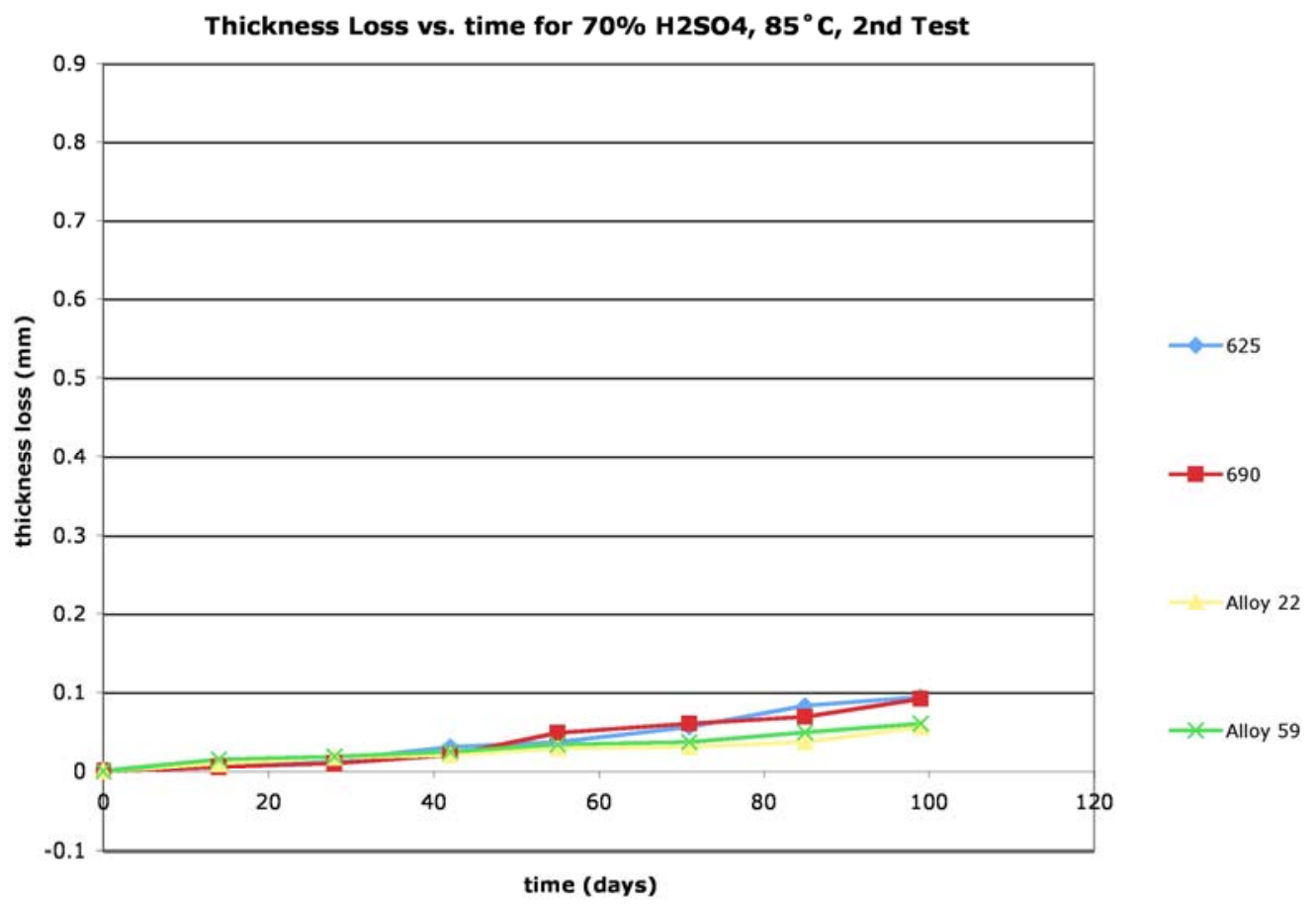

Figure A4b: Plot of Thickness Loss in mm Versus Time in Days for Materials in a 70 Percent $\mathrm{H}_{2} \mathrm{SO}_{4}$ Solution at $85^{\circ} \mathrm{C}$ Tested for a Second Time to Confirm Trends. 


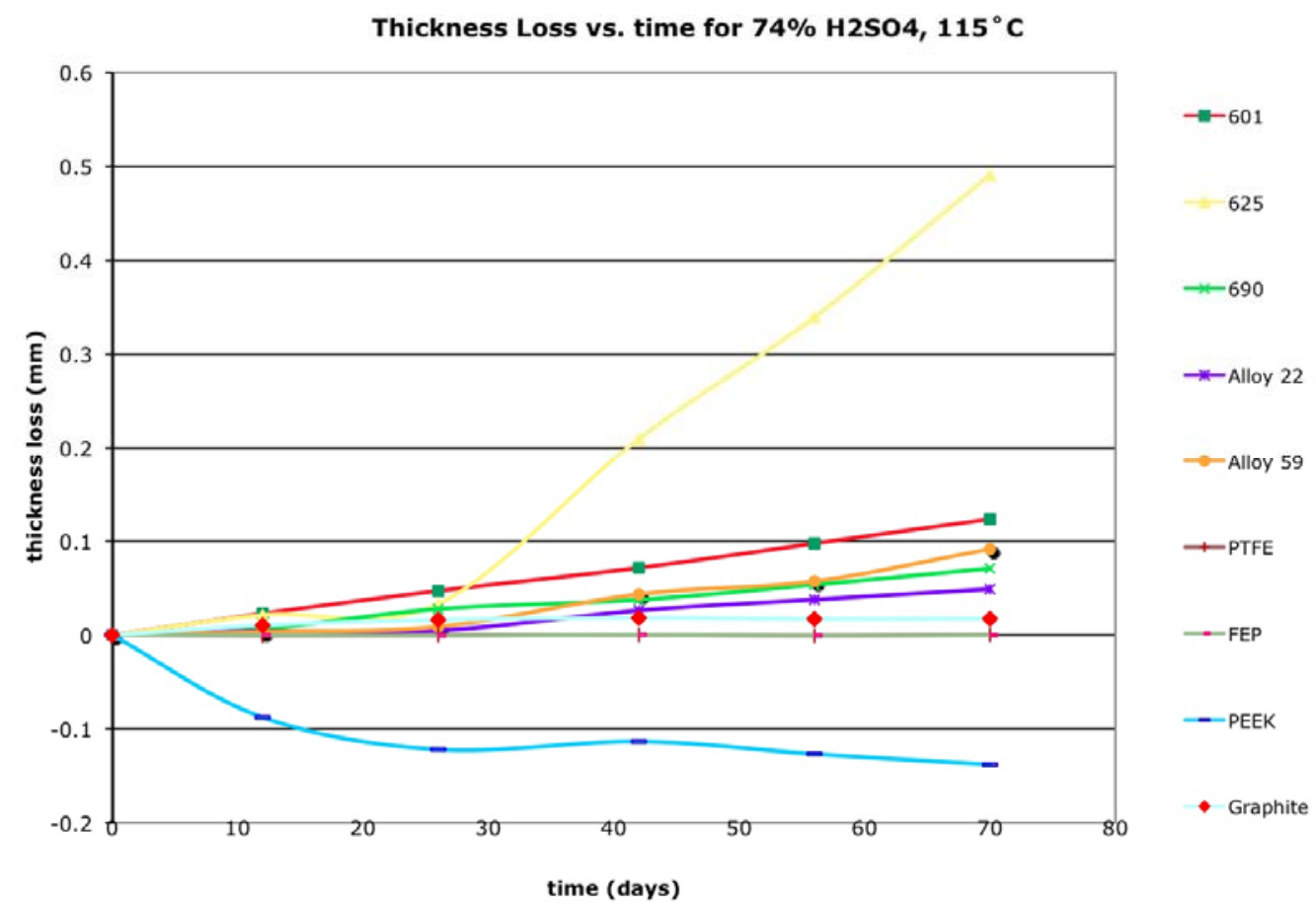

Figure A5a: Plot of Thickness Loss in mm Versus Time in Days for Materials in a 74 Percent $\mathrm{H}_{2} \mathrm{SO}_{4}$ Solution at $115^{\circ} \mathrm{C}$.

Thickness Loss vs. time for $74 \% \mathrm{H}^{2 S O}, 115^{\circ} \mathrm{C}$, 2nd Test

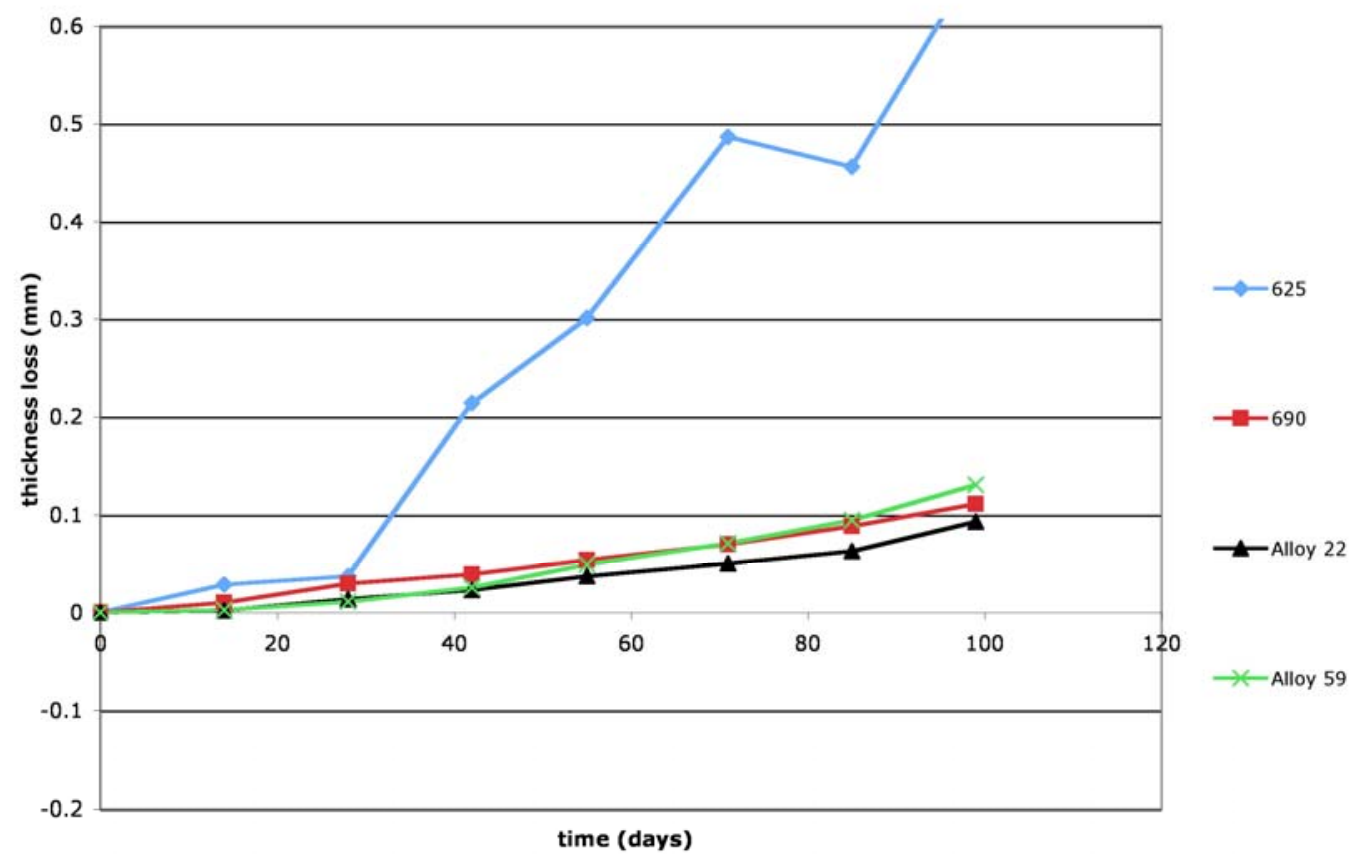

Figure A5b: Plot of Thickness Loss in mm Versus Time in Days for Materials in a 74 Percent $\mathrm{H}_{2} \mathrm{SO}_{4}$ Solution at $115^{\circ} \mathrm{C}$ Tested a Second Time to Confirm Trends. 
Thickness Loss vs. time for $74 \% \mathrm{H} 2 \mathrm{SO}, 115^{\circ} \mathrm{C}$, 2nd Test

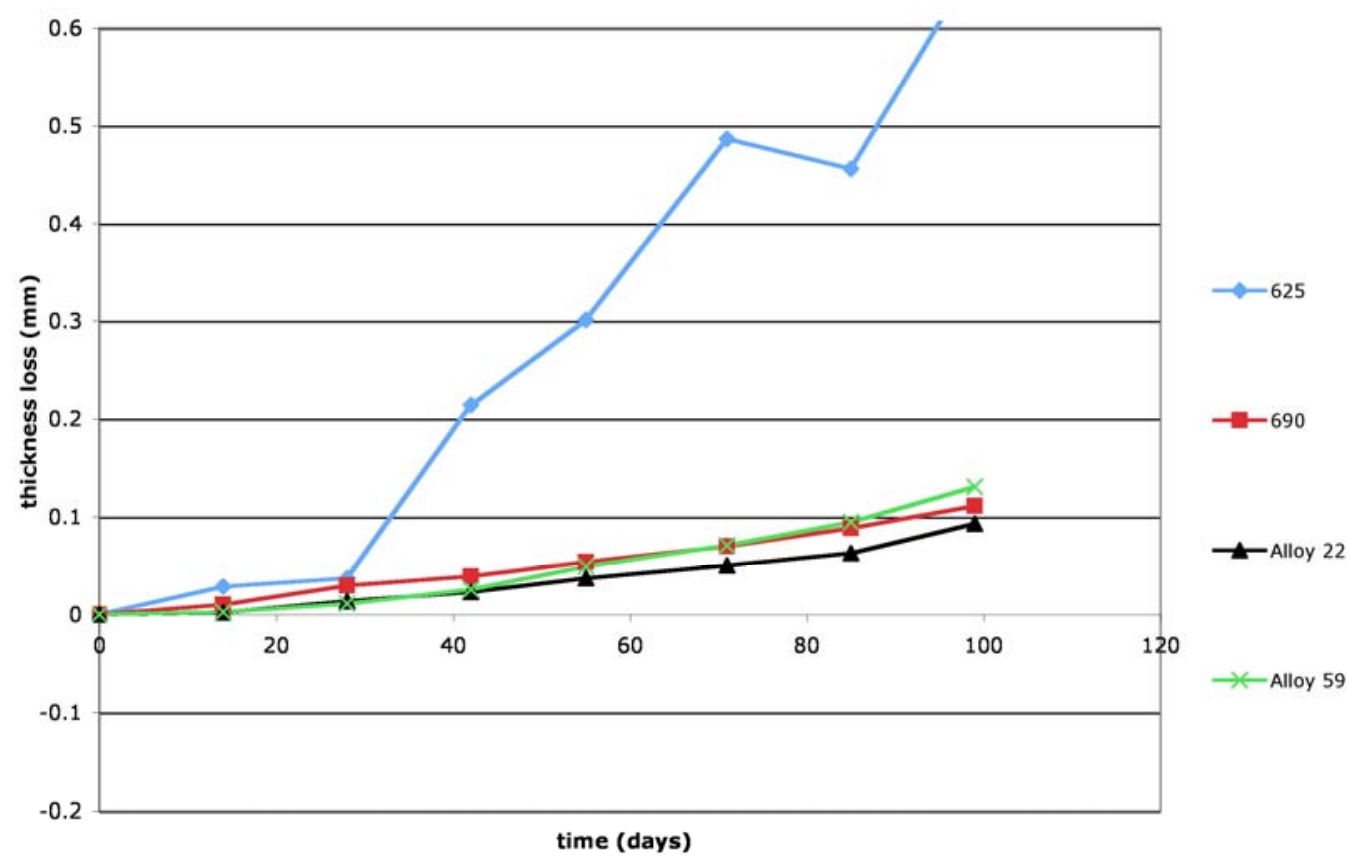

Figure A6: Plot of Thickness Loss in mm Versus Time in Days for Materials in a 80 Percent $\mathrm{H}_{2} \mathrm{SO}_{4}$ Solution at $150^{\circ} \mathrm{C}$.

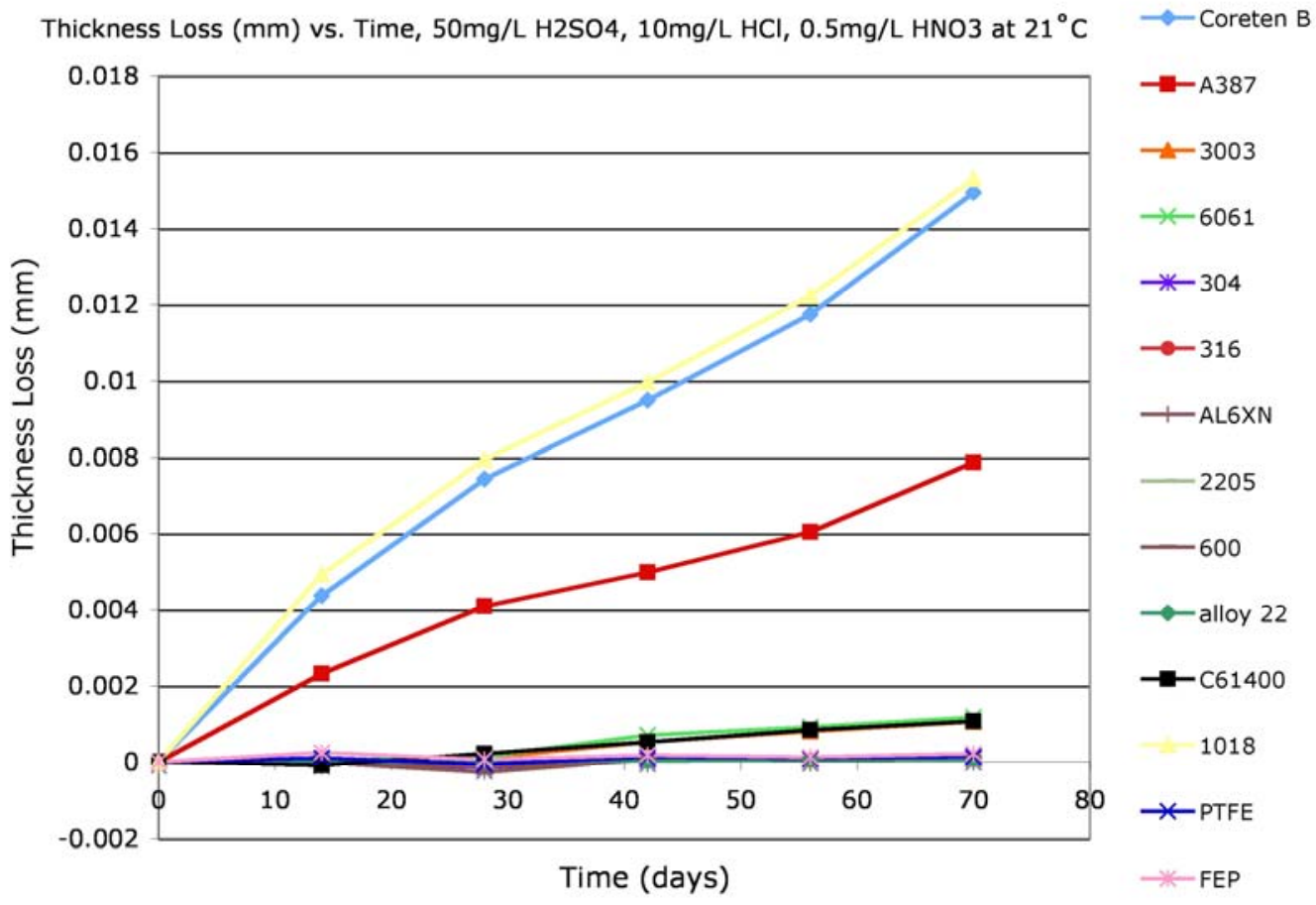

Figure A7: Plot of Thickness Loss in mm Versus Time in Days for Materials in a $50 \mathrm{mg} / \mathrm{L} \mathrm{H}_{2} \mathrm{SO}_{4} 10 \mathrm{mg} / \mathrm{L} \mathrm{HCl} 0.5 \mathrm{mg} / \mathrm{L} \mathrm{HNO}_{3}$ solution at $21^{\circ} \mathrm{C}$. 


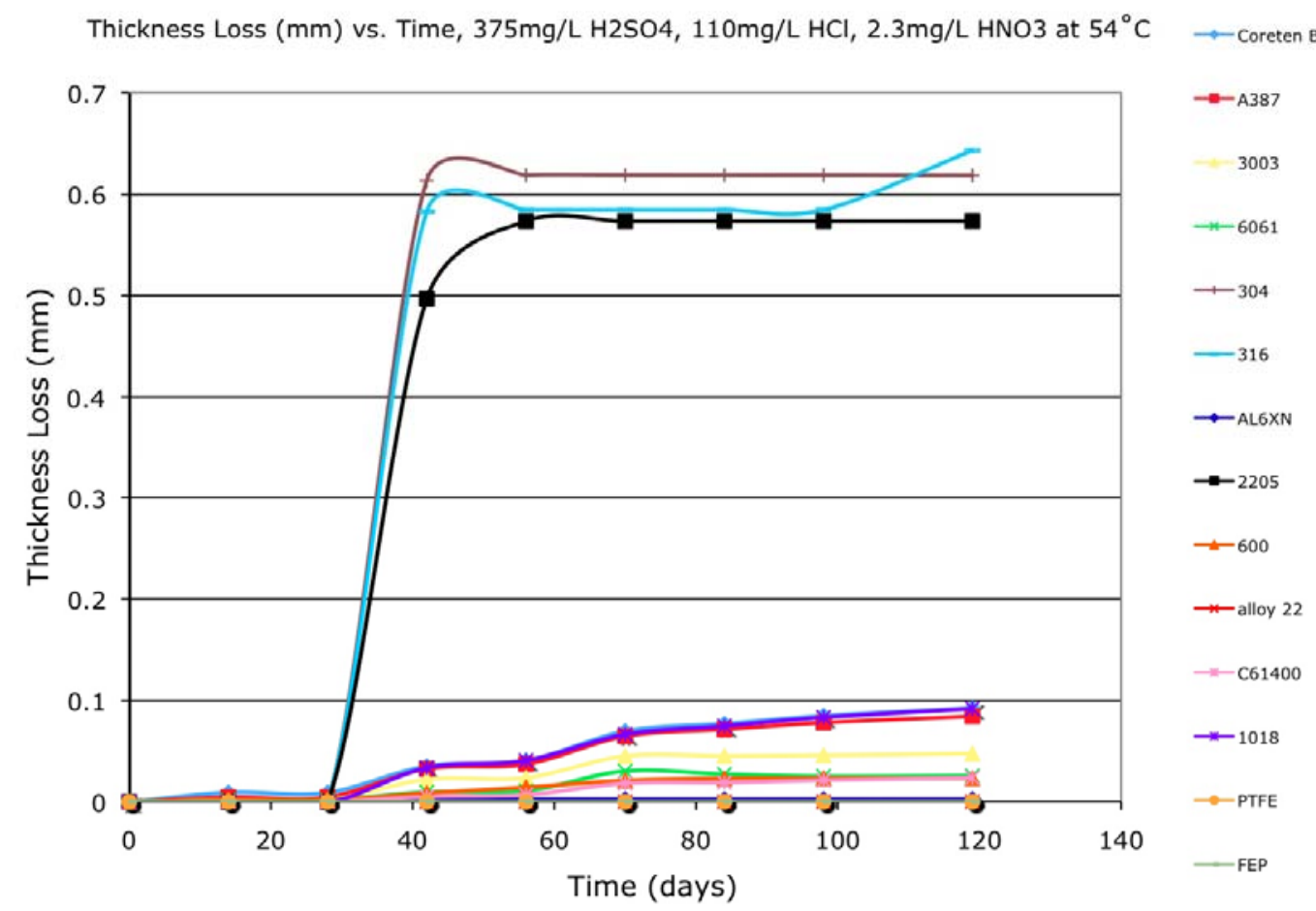

Figure A8a: Plot of Thickness Loss in mm Versus Time in Days for Materials in a $375 \mathrm{mg} / \mathrm{L} \mathrm{H}_{2} \mathrm{SO}_{4} 110 \mathrm{mg} / \mathrm{L} \mathrm{HCl} 2.3 \mathrm{mg} / \mathrm{L} \mathrm{HNO}{ }_{3}$ Solution at $54^{\circ} \mathrm{C}$.

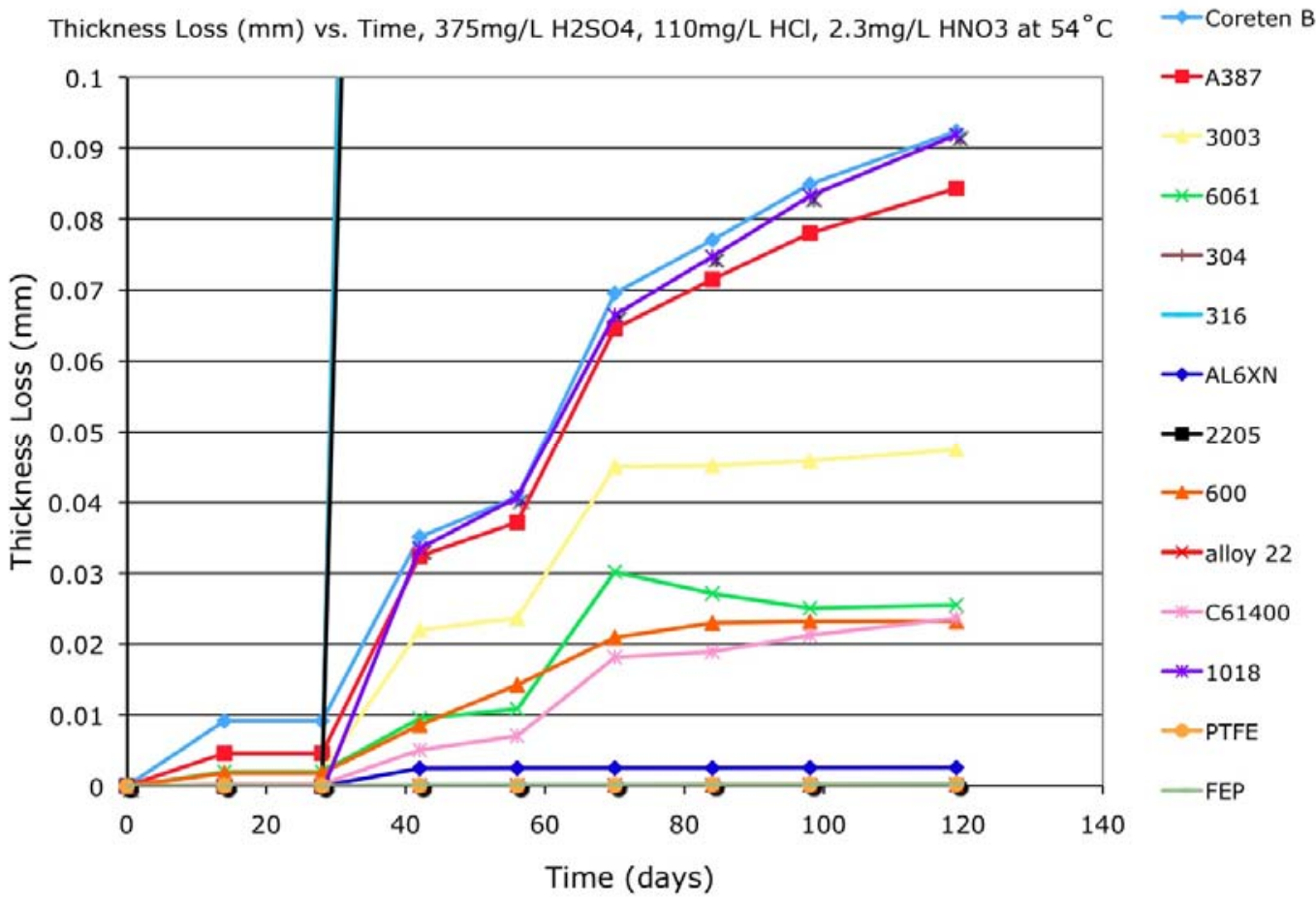

Figure A8b: Plot of Thickness Loss in mm Versus Time in Days for Materials in a $375 \mathrm{mg} / \mathrm{L} \mathrm{H}_{2} \mathrm{SO}_{4} 110 \mathrm{mg} / \mathrm{L} \mathrm{HCl} 2.3 \mathrm{mg} / \mathrm{L} \mathrm{HNO}_{3}$ Solution at $54^{\circ} \mathrm{C}$. This is the Same Plot as Figure $8 \mathrm{a}$, but the Axis is adjusted to Show Details of Some of the Samples. 


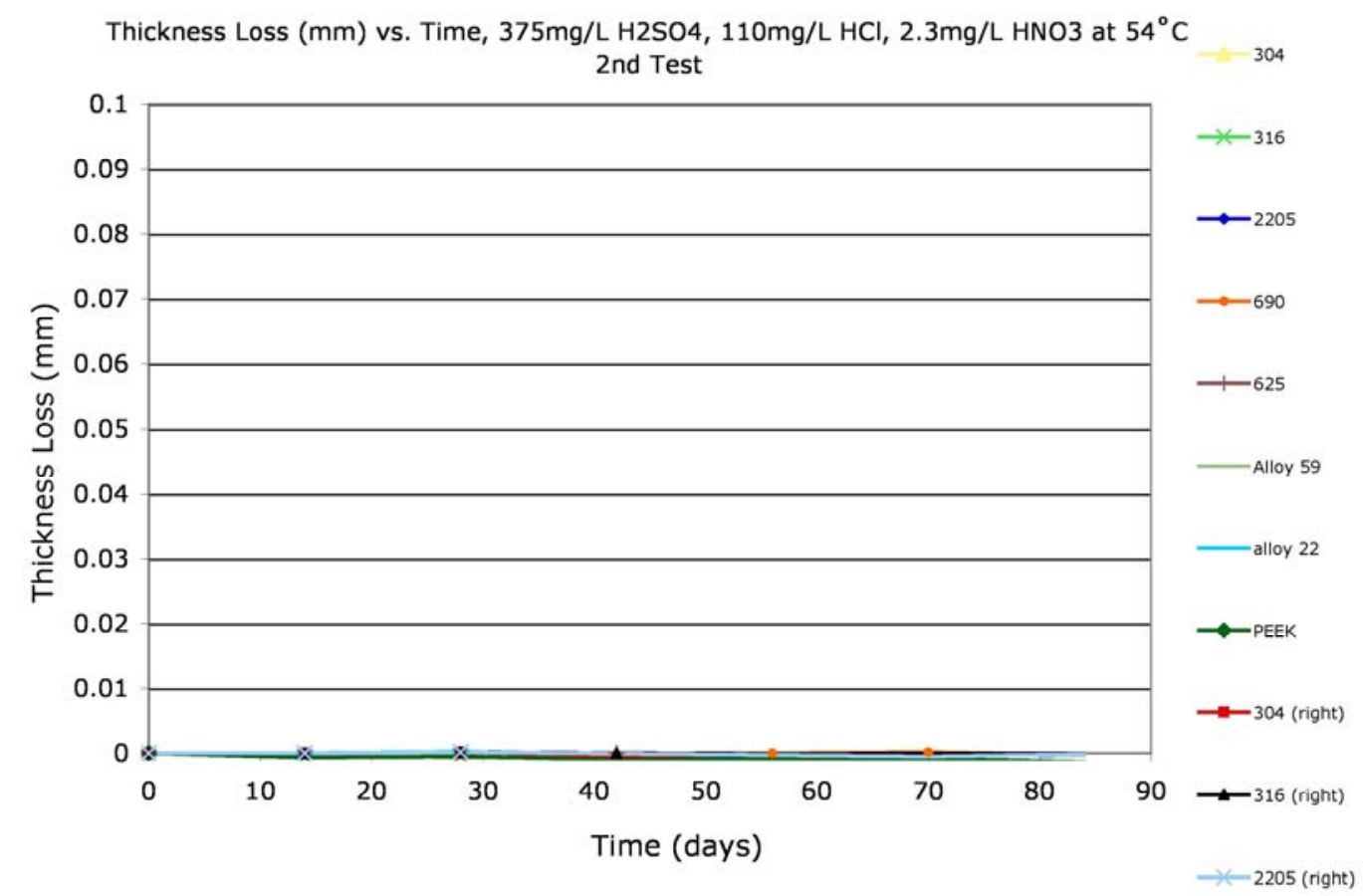

Figure A8c: Plot of Thickness Loss in mm Versus Time in Days for Materials in a $375 \mathrm{mg} / \mathrm{L} \mathrm{H}_{2} \mathrm{SO}_{4} 110 \mathrm{mg} / \mathrm{L} \mathrm{HCl} 2.3 \mathrm{mg} / \mathrm{L} \mathrm{HNO}_{3}$ Solution at $54^{\circ} \mathrm{C}$ Tested a Second Time to Confirm Trends.

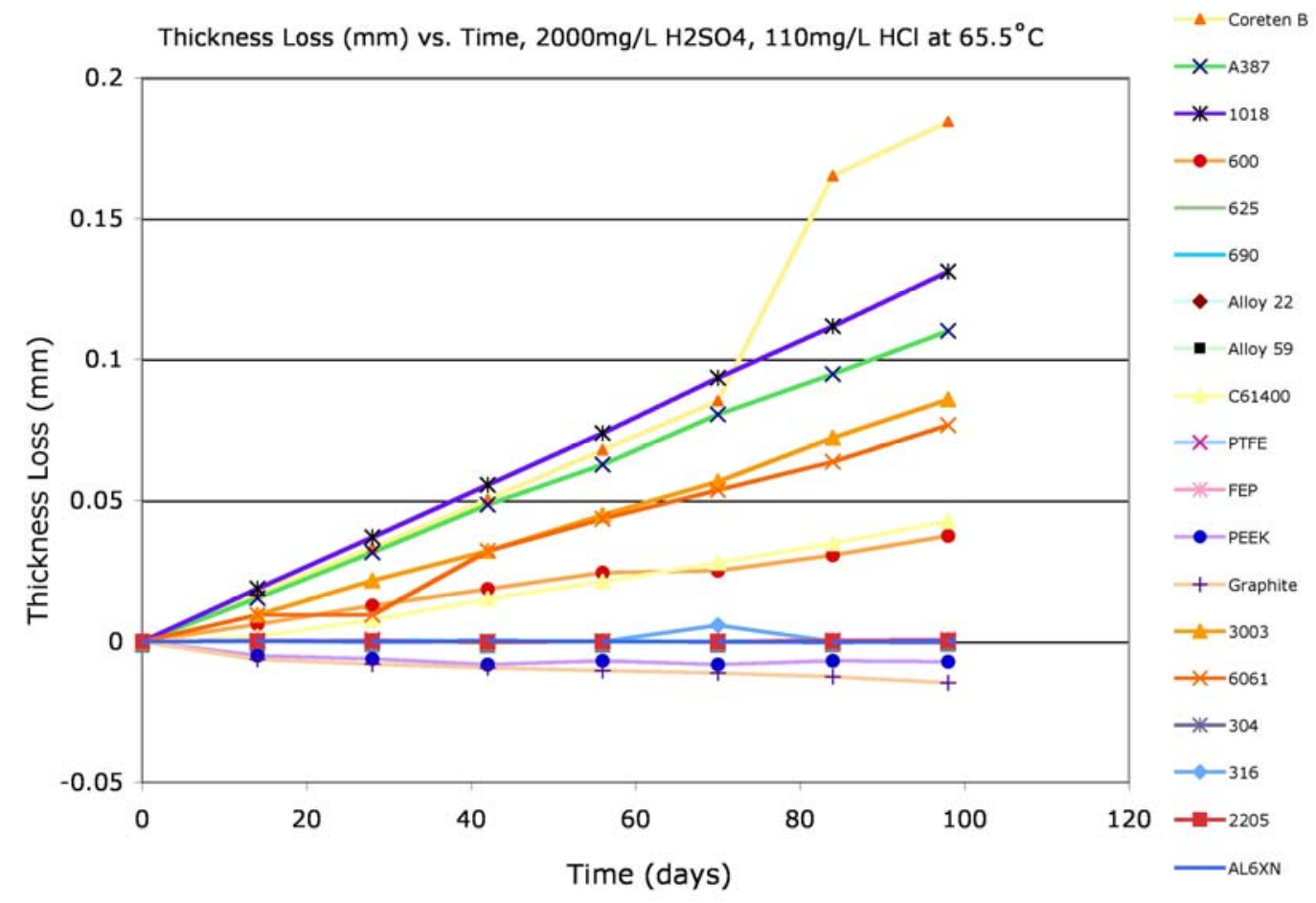

Figure A9: Plot of Thickness Loss in $\mathrm{mm}$ Versus Time in Days for Materials in a $2000 \mathrm{mg} / \mathrm{L} \mathrm{H}_{2} \mathrm{SO}_{4} 110 \mathrm{mg} / \mathrm{L} \mathrm{HCl} \mathrm{Solution} \mathrm{at} 65.5^{\circ} \mathrm{C}$. 


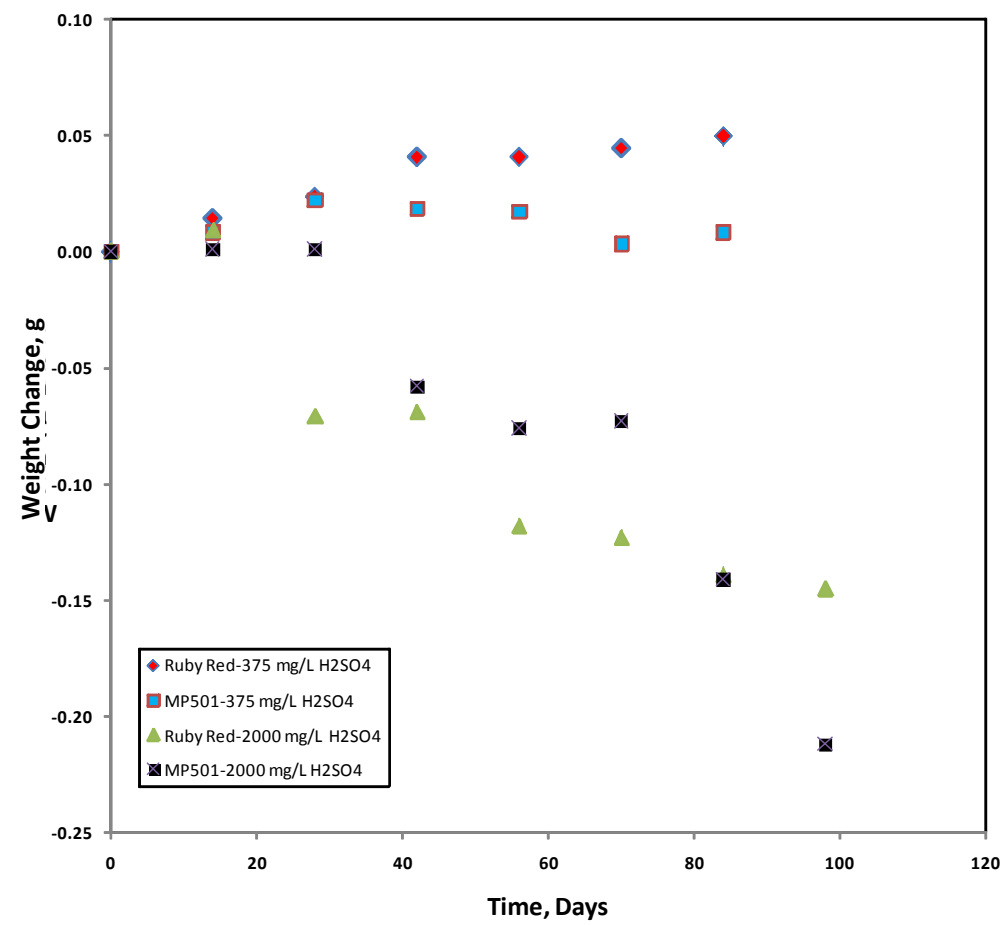

Figure A10a: Plot of Weight Change Versus Time in Days for the Ruby Red and MP501 Coatings in the $375 \mathrm{mg} / \mathrm{L} \mathrm{H}_{2} \mathrm{SO}_{4}$ $\left(54^{\circ} \mathrm{C}\right)$ and $2000 \mathrm{mg} / \mathrm{L} \mathrm{H}_{2} \mathrm{SO}_{4}\left(65.5^{\circ} \mathrm{C}\right)$ Solutions.

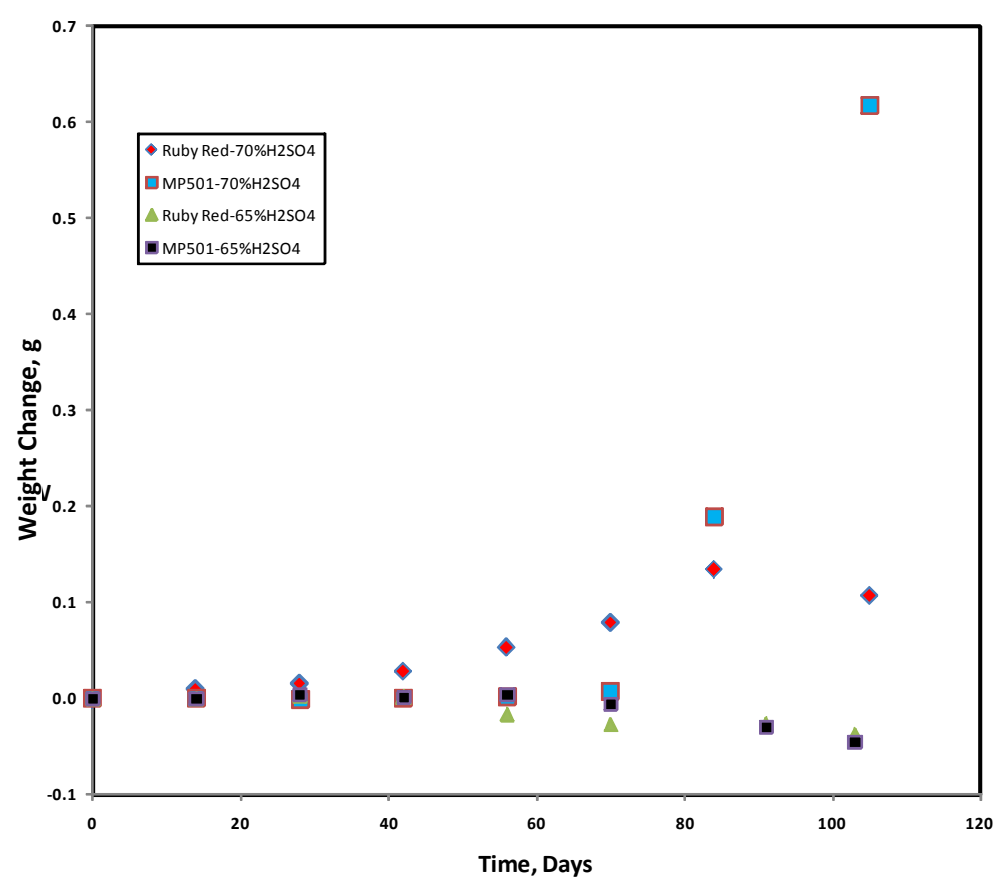

Figure A10b: Plot of Weight Change Versus Time in Days for the Ruby Red and MP501 Coatings in the 65 Percent $\mathrm{H}_{2} \mathrm{SO}_{4}\left(50^{\circ} \mathrm{C}\right)$ and 70 Percent $\mathrm{H}_{2} \mathrm{SO}_{4}\left(85^{\circ} \mathrm{C}\right)$ Solutions. 